\title{
Modelagem Numérica da Dispersão da Pluma do Emissário Submarino de Santos
}

Dissertação apresentada ao Instituto Oceanográfico da Universidade de São Paulo, como parte dos requisitos para obtenção do título de Mestre em Ciências, área de Oceanografia Física.

Orientador:

Prof. Dr. Belmiro Mendes de Castro Filho

S $\tilde{A}$ O P A U L O

2009 


\section{UNIVERSIDADE DE SÃO PAULO}

\section{INSTITUTO OCEANOGRÁFICO}

Modelagem Numérica da Dispersão da Pluma do Emissário Submarino de Santos

\section{Helvio Prevelato Gregório}

Dissertação apresentada ao Instituto Oceanográfico da Universidade de São Paulo, como parte dos requisitos para obtenção do título de Mestre em Ciências, área de Oceanografia Física.

Julgada em ___ _

Prof. Dr. Belmiro Mendes de Castro Filho

$\operatorname{Prof}(\mathrm{a}) \cdot \operatorname{Dr}(\mathrm{a})$.

$\operatorname{Prof}(\mathrm{a}) \cdot \operatorname{Dr}(\mathrm{a})$

S Ã O P A U L O

2009 


\section{Sumário}

$\begin{array}{lll}\mathbf{1} & \text { Introdução } & \mathbf{1}\end{array}$

1.1 Eficiência, vantagens e desvantagens dos emissários submarinos . . . . 2

1.2 Tratamento do esgoto . . . . . . . . . . . . . . . 3

1.3 Processos de mistura do efluente no meio marinho . . . . . . . . . . . 4

1.3 .1 Campo próximo . . . . . . . . . . . . . 5

1.3 .2 Campo distante . . . . . . . . . . . . . 7

1.3.3 Modelagem numérica da mistura de efluentes no meio marinho 7

1.4 Região de interesse: Baía de Santos . . . . . . . . . . . . . . . . 9

1.5 O emissário submarino de Santos . . . . . . . . . . . . . 11

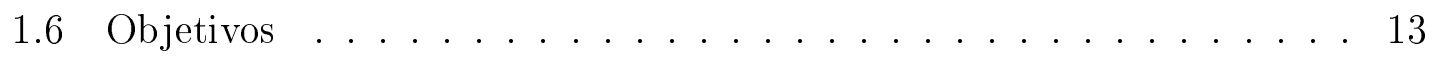

\begin{tabular}{lll}
\hline 2 & Métodos & 14
\end{tabular}

2.1 Modelagem hidrodinâmica . . . . . . . . . . . . . . . . . 14

2.2 Modelagem do campo próximo . . . . . . . . . . . . . . . 26

2.3 Interface entre os modelos de campo próximo e distante . . . . . . . . 27

2.4 Modelagem do campo distante . . . . . . . . . . . . . . . 29

2.5 Projetos para o emissário submarino de Santos . . . . . . . . . . . . . . . 31

2.6 Cenários propostos . . . . . . . . . . . . . . . . . 31

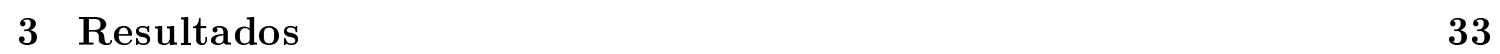

3.1 Sistema frontal climatológico . . . . . . . . . . . . . . . 34

3.2 Modelagem hidrodinâmica . . . . . . . . . . . . . . 35

3.2 .1 Nível . . . . . . . . . . . . . . . . . . . . . 36

3.2 .2 Velocidade . . . . . . . . . . . . . . . . 39

3.2 .3 Densidade . . . . . . . . . . . . . . . . . . 51

3.3 Modelagem do campo próximo . . . . . . . . . . . . . . 59

3.4 Modelagem do campo distante . . . . . . . . . . . . . 66

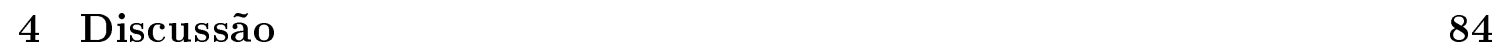

$4.1 \quad$ Sistema frontal climatológico . . . . . . . . . . . . . . . . 84

4.2 Simulações hidrodinâmicas . . . . . . . . . . . . . . . . 85 
4.3 Simulações da dispersão no campo próximo . . . . . . . . . . . . . . 90

4.4 Simulações da dispersão no campo distante . . . . . . . . . . . . . 95

$\begin{array}{lll}5 & \text { Conclusões } & 96\end{array}$

\begin{tabular}{|lll}
\hline A O Modelo Numério DELFT3D-FLOW & 97
\end{tabular}

\begin{tabular}{ll}
\hline B O Modelo Numério UM3 & 101
\end{tabular} 


\section{Agradecimentos}

Ao meu orientador Prof. Dr. Belmiro Mendes de Castro Filho, por toda paciência, ensinamentos e atenção dada a mim em todos os momentos.

Aos professores do IOUSP que contribuem cada dia mais em minha formação.

À Dra. Adriene F. Pereira, diretora da Hidromares, por toda a ajuda, ensinamento e compreensão.

Aos grandes amigos de turma, Marcão, Bruno, Piero, Luis Felipe e Marinho e também de outras turmas: Lê, Wandrey, Lucas, Franzé e todos mais que tive contato durante este período. Muito obrigado pela ajuda e compreensão nos momentos de ausência e pela companhia e boas trocas de idéias e amizade nos momentos presentes.

Um agradecimento especial a minha querida Lívia Melzi, que me deu forças na hora em que precisei, me levantou quando estava derrubado, que me apoiou do início ao fim e foi muito importante para que esta etapa da minha vida fosse cumprida. Você está e estará sempre no meu coração.

Agradeço também minha mãe Regina e minhas irmãs, Érica e Núbia, pelo apoio incondicional e pela compreensão pelo tempo ausente. Nós estaremos sempre juntos.

Por fim, deixo meu agradecimento especial ao meu amado pai (e sempre presente) Helvio Gregório, por todos os ensinamentos e educação transmitida à mim durante sua vida, que me fez tornar o que eu sou hoje. Esta conquista é nossa. 


\section{Resumo}

A dispersão dos efluentes do emissário submarino de Santos foi estudada por meio de modelagem numérica, acoplando-se modelos hidrodinâmico, de dispersão no campo próximo e no campo distante. As simulações foram realizadas para o projeto original do emissário de 1979, para a nova configuração de 2009 e para terceiro arranjo sugerido por este estudo, que dobra o comprimento do duto em relação ao projeto original. As diluições foram modeladas em cenários ambientais com propriedades marinhas e estuarinas climatológicas de verão, juntamente com forçantes atmosféricas climatológicas da mesma estação, simulando ausência de vento, presença de vento médio e presença de vento médio seguido por passagem de frente fria climatológica (obtida por este estudo). Com as devidas validações do modelo hidrodinâmico, a diluição, tanto no campo próximo quanto no campo distante, foi fortemente regida pela estratificação da coluna dágua e pela velocidade das correntes. O cenário sem vento apresentou as maiores estratificações, menores velocidades e originou as menores diluições em oposição ao cenário que simulou a passagem de frente fria. Dentre os projetos de emissário analisados, aquele proposto por este estudo apresentou plumas com menores comprimentos horizontais e menores profundidades, atingindo a costa uma só vez. O projeto original e o novo que será implantado em 2009 apresentaram, comparativamente, plumas mais extensas e profundas, interceptando a costa em diversas situações.

Descritores: dispersão; campo próximo; campo distante; modelagem numérica; emissário submarino de Santos; estuário de Santos; Baía de Santos. 


\section{Abstract}

Sewage plume dispersion for the Santos outfall was studied using numerical models, coupling hydrodynamic, near field and far field models. Experiments were conducted for the 1979 original outfall design, for the new 2009 outfall configuration and also for a third arrangement suggested here, which duplicates the emissary length comparatively to the original 1979 project. Dilutions were modeled in environmental sceneries with summer climatological estuarine and marine properties, together with climatological atmospheric forcing for the same season, simulating no wind conditions, mean wind forcing and mean wind followed by a climatological cold front (developed at this study) passage. After the appropriate hydrodynamic numerical model validation, the dilution, at the near field as well as at the far field, was strongly determined by the vertical water stratification and by the current velocities. The no-wind scenery presented the highest stratifications, smallest velocities and originated the smallest dilutions, in opposition to the cold-front-scenery. Among the sewage outfall projects considered, the one presented at this study showed the shallowest plumes, with the smallest horizontal lengths, reaching the coast only once. The original 1979 project and the 2009 configuration showed, comparatively, the deepest and widest plumes reaching the coast in several situations.

Descriptors: dispersion; nearfield; farfield; numerical modeling; Santos outfall; Santos estuary; Santos Bay. 


\section{Lista de Figuras}

1.1 Composição de imagens de satélite noturnas ressaltando as áreas cos-

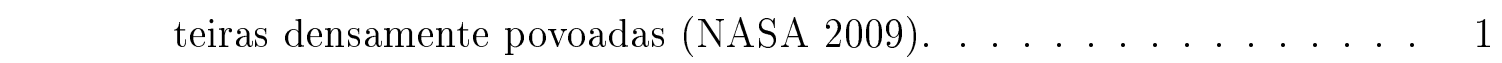

1.2 No painel da esquerda, ensaio laboratorial de uma descarga em um corpo de água com estratificação. No painel da direita, escalas espa-

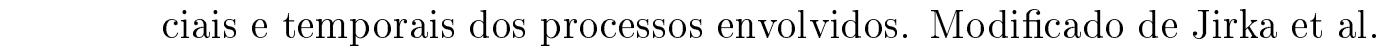

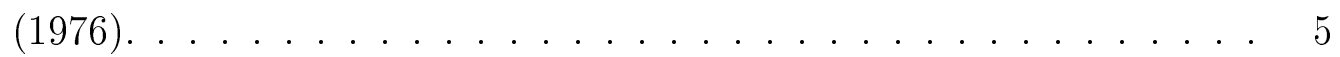

1.3 No painel da esquerda, efluente que se desloca livremente sem inter\begin{tabular}{|c|}
\hline ação com o fundo. No painel da direita, efluente interagindo com o \\
\hline
\end{tabular} fundo. Fonte: Jirka et al. $(1976)$. . . . . . . . . . . . . . . . 7

1.4 Processos envolvidos na modelagem numérica da diluição de efluentes - de emissários submarinos. . . . . . . . . . . . . . 8

1.5 Localização geográfica da Baía de Santos e os principais municípios situados no entorno da mesma. O emissário submarino de Santos está indicado na figura pela reta preta. . . . . . . . . . . . 9

1.6 Complexo estuarino da baixada santista. Em destaque as principais \begin{tabular}{|c|}
\hline feições citadas neste trabalho. Composição de imagens LandSat (Mi- \\
\hline
\end{tabular}

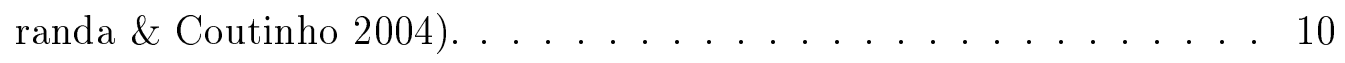

2.1 Representação gráfica da grade utilizado nas simulações hidrodinâmicas. No menor painel, detalhe da resolução próxima ao local do emissário submarino de Santos. . . . . . . . . . . . . . 17

2.2 Representação gráfica da resolução vertical adotada na simulação hidrodinâmica. ...................... 18

2.3 Batimetria interpolada utilizada nas simulações hidrodinâmicas. . . . 18

2.4 Localização dos principais rios na baixada santista, considerados nas simulações hidrodinâmicas. . . . . . . . . . . . . . . . 19

2.5 Distribuições horizontais em superfície, $20 \mathrm{~m}$ e no fundo para a tem-

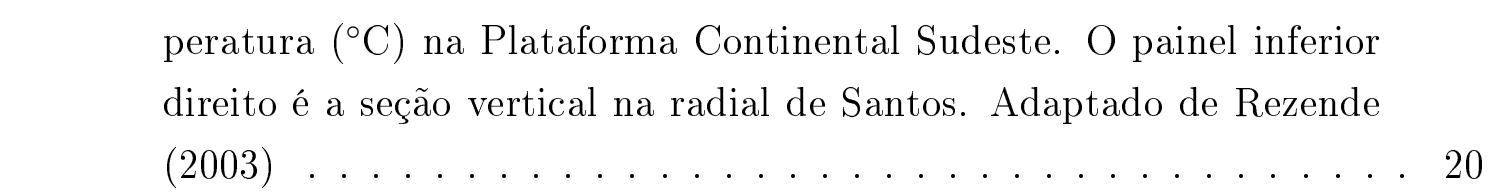


2.6 Distribuições horizontais em superfície, $20 \mathrm{~m}$ e no fundo para a sali-

nidade na Plataforma Continental Sudeste. O painel inferior direito

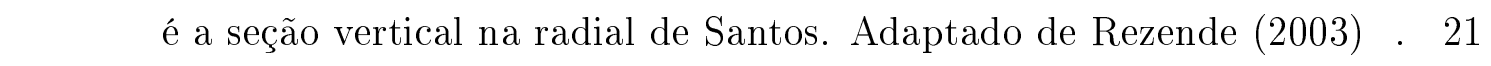

2.7 Os pontos pretos na figura representam locais de coleta de dados

\begin{tabular}{|c|c|}
\hline de temperatura e salinidade na Baía de Santos e canais estuarinos \\
\hline
\end{tabular}

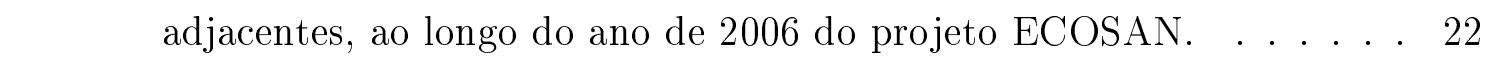

2.8 Distribuições horizontais de temperatura $\left({ }^{\circ} \mathrm{C}\right)$ para os meses de verão,



2.9 Distribuições horizontais de salinidade para os meses de verão, obtidos no projeto ECOSAN, no ano de 2006, para o estuário santista. . . . . 23

2.10 Distribuição horizontal da temperatura $\left({ }^{\circ} \mathrm{C}\right)$, representando a condição inicial para as simulações hidrodinâmicas. A profundidade refe-

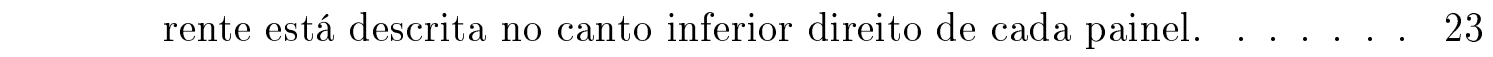

2.11 Distribuição horizontal da salinidade, representando a condição inicial \begin{tabular}{|c|}
\hline para as simulações hidrodinâmicas. A profundidade referente está \\
\hline
\end{tabular}

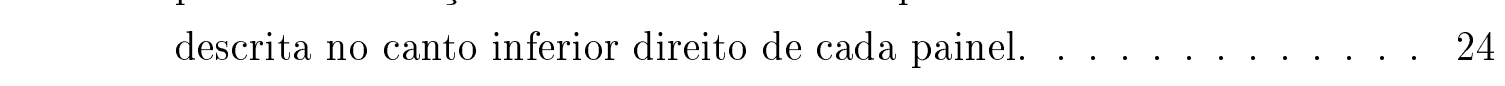

2.12 Seção vertical de temperatura $\left({ }^{\circ} \mathrm{C}\right)$, representando a condição de \begin{tabular}{|l}
\hline borda para as simulações hidrodinâmicas. A borda referente esta \\
\hline descrita no título de cada painel. . . . . . . . . . . . . . . 24
\end{tabular}

2.13 Seção vertical de salinidade, representando a condição de borda para \begin{tabular}{|c|}
\hline as simulações hidrodinâmicas. A borda referente esta descrita no \\
\hline
\end{tabular} título de cada painel. . . . . . . . . . . . . . . 25

2.14 Frequência de ocorrência de ventos no verão 2006 e 2007 para a laje - de Santos. . . . . . . . . . . . . . . . . 25

2.15 Possíveis acoplamentos de massa(M) e fluxo, gerado pela descarga dos \begin{tabular}{|l|l|l|l|}
\hline efluentes $\left(\mathrm{Q}_{0}\right)$ no modelo de campo distante (Zhang \& Adams (1999)) 27 \\
\hline
\end{tabular}

2.16 Relação entre a pluma prevista pelo modelo de campo próximo (es\begin{tabular}{|c|}
\hline querda) e a grade numérica imposta para o modelo de campo distante \\
\hline
\end{tabular} (direita). . . . . . . . . . . . . . . . . 29

2.17 Localização dos projetos do ESS utilizados nas simulações numéricas. 31

$3.1 \quad$ Nível do mar exemplificando ciclos de enchente-vazante em período de \begin{tabular}{|c|}
\hline marés de quadratura (segmento em vermelho à esquerda) e de marés \\
\hline
\end{tabular} \begin{tabular}{|c|}
\hline de sizígia (segmento em vermelho à direita), obtido por este estudo \\
\hline
\end{tabular}

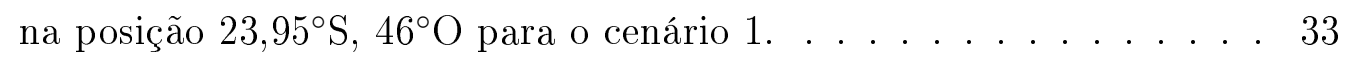

3.2 Representação vetorial climatológica da passagem de sistema frontal \begin{tabular}{|c|}
\hline na Baía de Santos. O dia 0 representa o dia da entrada do sistema \\
\hline
\end{tabular} frontal. O Norte aponta para cima. . . . . . . . . . . . 35 
3.3 Variação do nível $(\mathrm{m})$ ao longo de um ciclo de enchente-vazante em \begin{tabular}{|c|}
\hline maré de quadratura, para o cenário 1. Cada painel indica um instante \\
\hline de tempo, identificado pelo índice no canto superior esquerdo e a curva
\end{tabular} - de nível em destaque. . . . . . . . . . . . . . . . 36

3.4 Variação do nível $(\mathrm{m})$ ao longo de um ciclo de enchente-vazante em maré de sizígia, para o cenário 1. Cada painel indica um instante de \begin{tabular}{|c|}
\hline tempo, identificado pelo índice no canto superior esquerdo e a curva \\
\hline
\end{tabular}

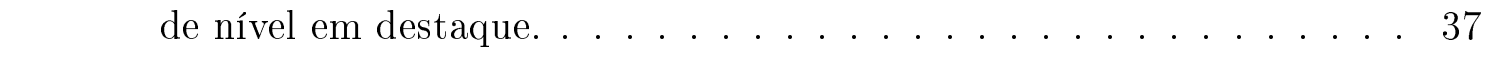

3.5 Variação do nível do mar na posição $23,95^{\circ} \mathrm{S}, 46,30^{\circ} \mathrm{O}$ para o cenário 1.38

$3.6 \quad$ Campos de velocidade na superfície (superior) e fundo (inferior) para \begin{tabular}{|l|}
\hline instante de baixamar em período de quadratura para o cenário 1. Os \\
\hline vetores indicam a direção das correntes. As cores correspondem as \\
\hline magnitudes. Estão plotados 1 a cada 4 vetores. . . . . . . . . . . 39
\end{tabular}

3.7 Perfis tridimensionais de velocidade em instante de baixamar em \begin{tabular}{|c|}
\hline período de quadratura para o cenário 1 nos locais de lançamento \\
\hline
\end{tabular}

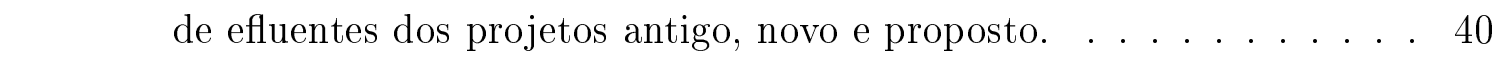

3.8 Perfis tridimensionais de velocidade em instante de preamar em período \begin{tabular}{|c|}
\hline de quadratura para o cenário 1 nos locais de lançamento de efluentes \\
\hline
\end{tabular} - dos projetos antigo, novo e proposto. . . . . . . . . . . . 41

3.9 Perfis tridimensionais de velocidade em instante de baixamar em \begin{tabular}{|c|}
\hline período de sizígia para o cenário 1 nos locais de lançamento de eflu- \\
\hline
\end{tabular}

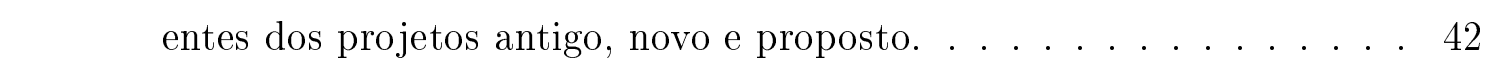

3.10 Campos de velocidade na superfície (superior) e fundo (inferior) para \begin{tabular}{|c|}
\hline instante de preamar em período de sizígia para o cenário 1. Os ve- \\
\hline
\end{tabular} \begin{tabular}{|c|c|}
\hline tores indicam a direção das correntes. As cores correspondem as \\
\hline
\end{tabular}

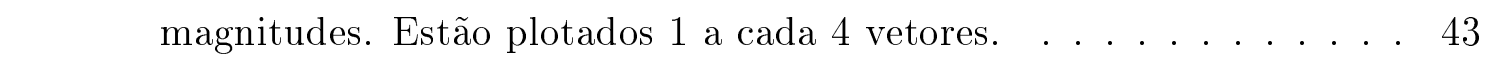

3.11 Campos de velocidade na superfície (superior) e fundo (inferior) para \begin{tabular}{|c|}
\hline instante de preamar em período de quadratura para o cenário 2. Os \\
\hline vetores
\end{tabular} \begin{tabular}{|c|}
\hline vetores indicam a direção das correntes. As cores correspondem as \\
\hline magni
\end{tabular} magnitudes. Estão plotados 1 a cada 4 vetores. . . . . . . . . . . . . 44

3.12 Perfis tridimensionais de velocidade em instante de preamar em período \begin{tabular}{|c|}
\hline de quadratura para o cenário 2 nos locais de lançamento de efluentes \\
\hline
\end{tabular} dos projetos antigo, novo e proposto . . . . . . . . . . 45

3.13 Campos de velocidade na superfície (superior) e fundo (inferior) para \begin{tabular}{|c|}
\hline instante de preamar em período de sizígia para o cenário 2. Os ve- \\
\hline tores indicam a direc̃̃o das
\end{tabular} \begin{tabular}{|c|c|}
\hline tores indicam a direção das correntes. As cores correspondem as \\
\hline
\end{tabular} magnitudes. Estão plotados 1 a cada 4 vetores. . . . . . . . . . . 46 
3.14 Campos de velocidade na superfície (superior) e fundo (inferior) para \begin{tabular}{|c|}
\hline instante de baixamar em período de quadratura para o cenário 3. Os \\
\hline vetores indicam a direção das correntes. As cores correspondem as \\
\hline magnitudes. Estão plotados 1 a cada 4 vetores.
\end{tabular}

3.15 Perfis tridimensionais de velocidade em instante de preamar em período \begin{tabular}{|c|}
\hline de quadratura para o cenário 3 nos locais de lançamento de efluentes \\
\hline
\end{tabular} dos projetos antigo, novo e proposto. . . . . . . . . . . . 48

3.16 Campos de velocidade na superfície (superior) e fundo (inferior) para \begin{tabular}{|c|}
\hline instante de baixamar em período de sizígia para o cenário 3. Os ve- \\
\hline
\end{tabular} tores indicam a direção das correntes. As cores correspondem as

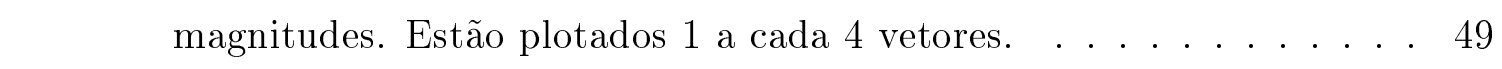

3.17 Campos de velocidade na superfície (superior) e fundo (inferior) para \begin{tabular}{|c|}
\hline instante de preamar em período de sizígia para o cenário 3. Os ve- \\
\hline
\end{tabular} \begin{tabular}{|c|c|}
\hline tores indicam a direção das correntes. As cores correspondem as \\
\hline
\end{tabular}

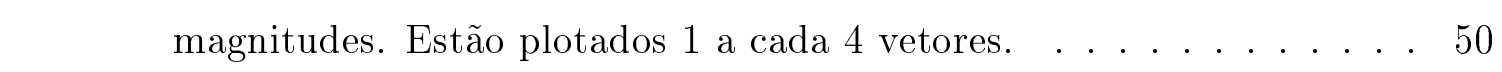

3.18 Campo de estratificação bruta ("bulk stratification") $\left(\mathrm{kg} \cdot \mathrm{m}^{-3}\right)$ para

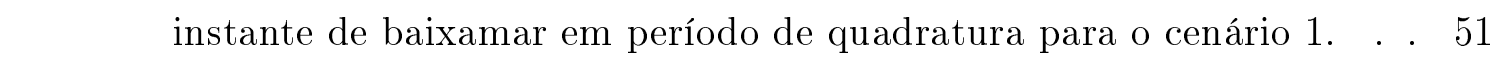

3.19 No painel da esquerda, seção vertical de densidade $\left(\mathrm{kg} . \mathrm{m}^{-3}\right)$ ao longo do emissário submarino de Santos para instante de baixamar de qua\begin{tabular}{|c|}
\hline dratura no cenário 1. No painel da direita estão representados os \\
\hline
\end{tabular} \begin{tabular}{|c|}
\hline perfis verticais ao final do emissário submarino de Santos para os \\
\hline
\end{tabular} \begin{tabular}{|c|}
\hline três projetos: antigo, novo e proposto. O valor de BS representa a \\
\hline
\end{tabular}

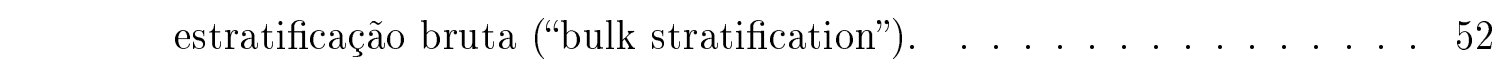

3.20 No painel da esquerda, seção vertical de densidade $\left(\mathrm{kg} . \mathrm{m}^{-3}\right)$ ao longo \begin{tabular}{|l|}
\hline do emissário submarino de Santos para instante de preamar de qua- \\
\hline dratura no cenário 1. No painel da direita estão representados os \\
\hline perfis vertical ao final do emissário submarino de Santos para os três \\
\hline projetos: antigo, novo e proposto. O valor de BS representa a estra- \\
\hline tificação bruta ("bulk stratification"). . . . . . . . . . . . . . . . . . . 53 \\
\hline
\end{tabular}

3.21 Campo de estratificação bruta ("bulk stratification") $\left(\mathrm{kg} . \mathrm{m}^{-3}\right)$ para

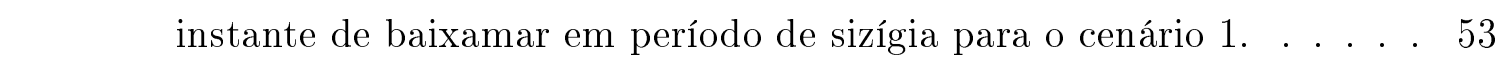

3.22 No painel da esquerda, seção vertical de densidade $\left(\mathrm{kg} . \mathrm{m}^{-3}\right)$ ao longo \begin{tabular}{|c|}
\hline do emissário submarino de Santos para instante de preamar de sizígia \\
\hline no cenário 1. No painel da direita estão representados os perfis verti- \\
\hline cal ao final do emissário submarino de Santos para os três projetos: \\
\hline antigo, novo e proposto. O valor de BS representa a estratificação \\
\hline bruta ("bulk stratification"). . . . . . . . . . . . . . . . . . . . . 54 \\
\hline 3.23 Campo de estratificação bruta ("bulk stratification") (kg.m ${ }^{-3}$ ) para \\
\hline instante de preamar em período de quadratura para o cenário 2. . . . 55 \\
\hline
\end{tabular} 
3.24 No painel da esquerda, seção vertical de densidade $\left(\mathrm{kg} \cdot \mathrm{m}^{-3}\right)$ ao longo do emissário submarino de Santos para instante de baixamar de sizígia no cenário 2. No painel da direita estão representados os perfis vertical ao final do emissário submarino de Santos para os três projetos: antigo, novo e proposto. O valor de BS representa a estratificação bruta ("bulk stratification"). . . . . . . . . . . . 56 56

3.25 Campo de estratificação bruta ("bulk stratification") (kg.m $\left.{ }^{-3}\right)$ para

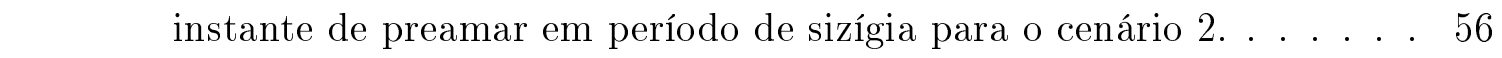

3.26 Campo de estratificação bruta ("bulk stratification") $\left(\mathrm{kg} . \mathrm{m}^{-3}\right)$ para \begin{tabular}{|ll}
\hline instante de baixamar em período de quadratura para o cenário 3. & . . 57
\end{tabular}

3.27 No painel da esquerda, seção vertical de densidade (kg. $\left.\mathrm{m}^{-3}\right)$ ao longo do emissário submarino de Santos para instante de baixamar de qua\begin{tabular}{|c|c|}
\hline dratura no cenário 3. No painel da direita estão representados os \\
\hline
\end{tabular} \begin{tabular}{|c|}
\hline perfis vertical ao final do emissário submarino de Santos para os três \\
\hline
\end{tabular} \begin{tabular}{|c|}
\hline projetos: antigo, novo e proposto. O valor de BS representa a estra- \\
\hline
\end{tabular} tificação bruta ("bulk stratification"). . . . . . . . . . . . . . 57

3.28 No painel da esquerda, seção vertical de densidade $\left(\mathrm{kg} \cdot \mathrm{m}^{-3}\right)$ ao longo \begin{tabular}{|c|}
\hline do emissário submarino de Santos para instante de baixamar de sizí- \\
\hline gia no cenário 3. No painel da direita estão representados os perfis \\
\hline vertical ao final do emissário submarino de Santos para os três proje- \\
\hline tos: antigo, novo e proposto. O valor de BS representa a estratificação \\
\hline bruta ("bulk stratification"). . . . . . . . . . . . . . . . . . . . 58 \\
\hline
\end{tabular}

3.29 No painel da esquerda, seção vertical de densidade $\left(\mathrm{kg} . \mathrm{m}^{-3}\right)$ ao longo do emissário submarino de Santos para instante de preamar de sizígia no cenário 3. No painel da direita estão representados os perfis vertical ao final do emissário submarino de Santos para os três projetos: \begin{tabular}{|c|c|}
\hline antigo, novo e proposto. O valor de BS representa a estratificação \\
\hline
\end{tabular} bruta ("bulk stratification"). . . . . . . . . . . . . 58

3.30 Representação tridimensional das plumas de efluentes no campo pró\begin{tabular}{|l|}
\hline ximo do emissário de Santos para o momento de baixamar de quadra- \\
\hline tura, no cenário 1. Os três projetos são representados conjuntamente \\
\hline de forma comparativa. A pluma da esquerda refere-se ao Projeto \\
\hline Proposto, a pluma central ao Projeto Novo e a pluma da direita ao \\
\hline Projeto Antigo. . . . . . . . . . . . . . . . . . . . . . 59
\end{tabular} 
3.31 Representação tridimensional das plumas de efluentes no campo próximo do emissário de Santos para o momento de preamar de quadratura, no cenário 1. Os três projetos são representados conjuntamente \begin{tabular}{|c|c|}
\hline de forma comparativa. A pluma da esquerda refere-se ao Projeto \\
\hline
\end{tabular} \begin{tabular}{|c|c|c|}
\hline Proposto, a pluma central ao Projeto Novo e a pluma da direita ao \\
\hline
\end{tabular} Projeto Antigo. . . . . . . . . . . . . . . . . 60

3.32 Representação tridimensional das plumas de efluentes no campo próximo do emissário de Santos para o momento de baixamar de sizígia, no cenário 1. Os três projetos são representados conjuntamente de forma comparativa. A pluma da esquerda refere-se ao Projeto \begin{tabular}{|c|}
\hline Proposto, a pluma central ao Projeto Novo e a pluma da direita ao \\
\hline
\end{tabular} Projeto Antigo. . . . . . . . . . . . . . . . . 61

3.33 Representação tridimensional das plumas de efluentes no campo próximo do emissário de Santos para o momento de preamar de sizígia, no \begin{tabular}{|c|}
\hline cenário 2. Os três projetos são representados conjuntamente de forma \\
\hline
\end{tabular} comparativa. A pluma da esquerda refere-se ao Projeto Proposto, a

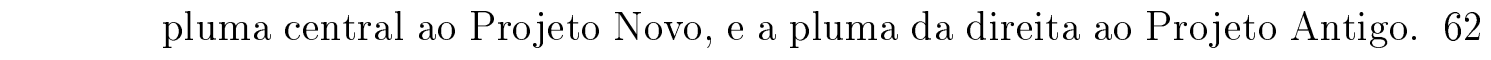

3.34 Representação tridimensional das plumas de efluentes no campo próximo do emissário de Santos para o momento de baixamar de quadra\begin{tabular}{|c|}
\hline tura, no cenário 3. Os três projetos são representados conjuntamente \\
\hline de
\end{tabular} \begin{tabular}{|c|c|}
\hline de forma comparativa. A pluma da esquerda refere-se ao Projeto \\
\hline
\end{tabular} \begin{tabular}{|c|}
\hline Proposto, a pluma central ao Projeto Novo e a pluma da direita ao \\
\hline
\end{tabular} Projeto Antigo. . . . . . . . . . . . . . . . . 63

3.35 Representação em profundidade das plumas de efluentes no campo próximo do emissário de Santos para o momento de baixamar de sizígia, no cenário 3. Os três projetos são representados conjuntamente \begin{tabular}{|c|}
\hline de forma comparativa. A pluma da esquerda refere-se ao Projeto \\
\hline Preposto a pluata
\end{tabular} \begin{tabular}{|c|}
\hline Proposto, a pluma central ao Projeto Novo, e a pluma da direita ao \\
\hline
\end{tabular} - Projeto Antigo. . . . . . . . . . . . . . . . . . 64

3.36 Representação em profundidade das plumas de efluentes no campo próximo do emissário de Santos para o momento de preamar de sizí\begin{tabular}{|c|}
\hline gia, no cenário 3. Os três projetos são representados conjuntamente \\
\hline de forma comparativa. A pluma da esquerda refere-se ao Projeto \\
\hline Proposto, a pluma central ao Projeto Novo, e a pluma da direita ao \\
\hline
\end{tabular} Projeto Antigo. . . . . . . . . . . . . . . 65

3.37 Frequência de ocorrência de concentração de efluente, em superfície, lançado pelo projeto antigo, para o período de enchente-vazante em quadratura, no cenário 1. . . . . . . . . . . . 66 
3.38 Frequência de ocorrência de concentração de efluente, em superfície,

lançado pelo projeto novo, para o período de enchente-vazante em
quadratura, no cenário 1. . . . . . . . . . . . 67

3.39 Frequência de ocorrência de concentração de efluente, em superfície,

\begin{tabular}{|c|}
\hline lançado pelo projeto proposto, para o período de enchente-vazante \\
\hline
\end{tabular}

- em quadratura, no cenário 1. . . . . . . . . . . . . 68

3.40 Frequência de ocorrência de concentração de efluente, em superfície,

\begin{tabular}{|c|}
\hline lançado pelo projeto antigo, para o período de enchente-vazante em \\
\hline
\end{tabular}



3.41 Frequência de ocorrência de concentração de efluente, em superfície,

lançado pelo projeto novo, para o período de enchente-vazante em

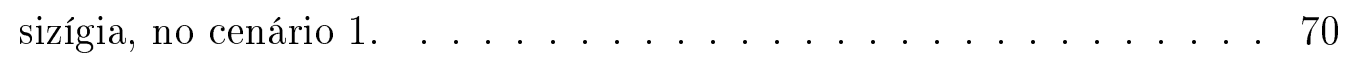

3.42 Frequência de ocorrência de concentração de efluente, em superfície, \begin{tabular}{|c|}
\hline lançado pelo projeto proposto, para o período de enchente-vazante \\
\hline
\end{tabular} - em sizígia, no cenário 1. . . . . . . . . . . . 71

3.43 Frequência de ocorrência de concentração de efluente, em superfície, lançado pelo projeto antigo, para o período de enchente-vazante em quadratura, no cenário 2. . . . . . . . . . . . . . 72

3.44 Frequência de ocorrência de concentração de efluente, em superfície, \begin{tabular}{|c|}
\hline lançado pelo projeto novo, para o período de enchente-vazante em \\
\hline
\end{tabular} quadratura, no cenário 2. . . . . . . . . . . . . 73

3.45 Frequência de ocorrência de concentração de efluente, em superfície, \begin{tabular}{|l|}
\hline lançado pelo projeto proposto, para o período de enchente-vazante \\
\hline
\end{tabular}

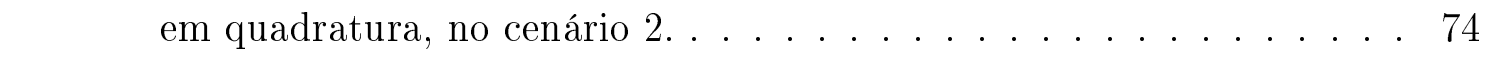

3.46 Frequência de ocorrência de concentração de efluente, em superfície, lançado pelo projeto antigo, para o período de enchente-vazante em sizígia, no cenário 2. . . . . . . . . . . . . . 75

3.47 Frequência de ocorrência de concentração de efluente, em superfície, \begin{tabular}{|c|}
\hline lançado pelo projeto novo, para o período de enchente-vazante em \\
\hline
\end{tabular} sizígia, no cenário 2. . . . . . . . . . . . . 76

3.48 Frequência de ocorrência de concentração de efluente, em superfície, \begin{tabular}{|c|}
\hline lançado pelo projeto proposto, para o período de enchente-vazante \\
\hline
\end{tabular}

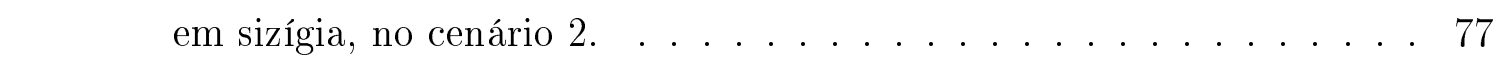

3.49 Frequência de ocorrência de concentração de efluente, em superfície, lançado pelo projeto antigo, para o período de enchente-vazante em quadratura, no cenário 3. . . . . . . . . . . . . . 78

3.50 Frequência de ocorrência de concentração de efluente, em superfície, lançado pelo projeto novo, para o período de enchente-vazante em quadratura, no cenário 3. . . . . . . . . . . . 79 
3.51 Frequência de ocorrência de concentração de efluente, em superfície, lançado pelo projeto proposto, para o período de enchente-vazante em quadratura, no cenário 3. . . . . . . . . . . . . . . . . 80

3.52 Frequência de ocorrência de concentração de efluente, em superfície, lançado pelo projeto antigo, para o período de enchente-vazante em sizígia, no cenário $3 . \ldots \ldots \ldots$. . . . . . . . . 81

3.53 Frequência de ocorrência de concentração de efluente, em superfície, \begin{tabular}{|c|}
\hline lançado pelo projeto novo, para o período de enchente-vazante em \\
\hline
\end{tabular} sizígia, no cenário $3 . \ldots \ldots \ldots$. . . . . . . . . . . 82

3.54 Frequência de ocorrência de concentração de efluente, em superfície, \begin{tabular}{|l|}
\hline lançado pelo projeto proposto, para o período de enchente-vazante \\
\hline
\end{tabular}

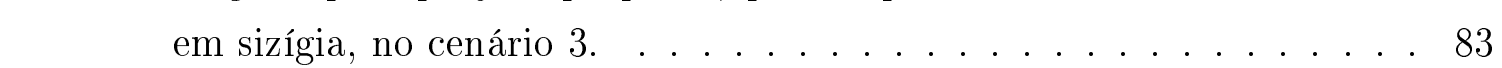

4.1 Seções estação versus tempo dos sistemas frontais que penetraram no Brasil em JANEIRO/2006. As linhas indicam que a frente passou \begin{tabular}{|c|}
\hline pela estação entre 09h00 (hora local) do dia anterior e 09h00 (horal \\
\hline
\end{tabular} local) do dia indicado (CPTEC/INPE $\| 1996)$. . . . . . . . . . 85

4.2 Variação do nível do mar na posição $23,95^{\circ} \mathrm{S}, 46,30^{\circ} \mathrm{O}$ para o cenário 1 (linha em preto) e para a previsão da DNH no mesmo ponto (linha em vermelho). . . . . . . . . . . . . . 86

4.3 Ventos, correntes modeladas e observadas, e variações do nível do mar nas proximidades da Ilha da Moela, a leste da saída da BS. As magnitudes do vento estão multiplicadas por $10^{-1}$. O painel superior (a) apresenta ventos medidos na Laje de Santos, correntes medidas \begin{tabular}{|l}
\hline por ADCP fundeado na isóbata de $20 \mathrm{~m}$ e oscilação do nível do mar \\
\hline no Porto de Santos obtidas pela DHN. O painel inferior da esquerda
\end{tabular} (b) apresenta resultados obtidos nos experimentos numéricos forçados pelo vento médio. O painel inferior da direita (c) apresenta resultados obtidos nos experimentos numéricos forçados pelo vento médio

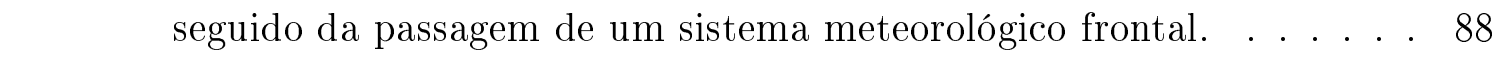

4.4 Esquema simplificado da circulação superficial na Baía de Santos em \begin{tabular}{|c|}
\hline instantes de preamar e baixamar, com a presença de vento médio ou \\
\hline
\end{tabular} sistema frontal. . . . . . . . . . . . . . . 990

4.5 Distribuição das diluições modeladas ao final do campo próximo em todas as simulações. Nos painéis (a) Projeto Antigo, (b) Novo e (c)

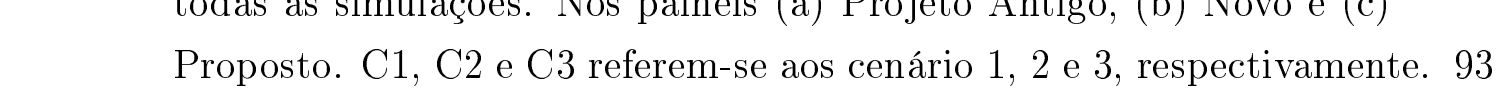


4.6 Posição central de afloramento da pluma de efluentes do emissário de Santos ao final do campo próximo. Em cada painel, o título indica o projeto correspondente. C1, C2 e C3 referem-se aos cenário 1, 2 e 3, respectivamente. ...................... 94 


\section{Lista de Tabelas}

1.1 Vantagens e desvantagens da implantação de emissários submarinos. . 3

2.1 Características gerais da grade utilizada nas simulações hidrodinâmicas. 17

2.2 Constantes harmônicas descritas para as bordas abertas oceânicas.

\begin{tabular}{|l|l|l|}
\hline Os valores listados correspondem à amplitude (Amp.) (m) & fase $\left(^{\circ}\right)$ \\
\hline
\end{tabular}

relativos a Greenwich. . . . . . . . . . . . . . . 19

2.3 Vazão imposta nas bordas abertas continentais simulando os princi-

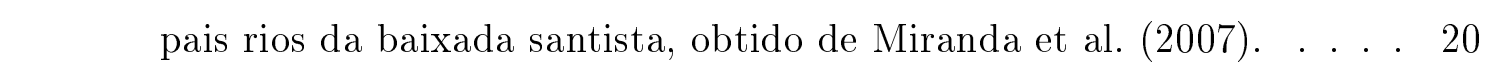

2.4 Projetos do emissário submarino de Santos para as simulações de campo próximo e distante. . . . . . . . . . . . . . 31

2.5 Cenários ambientais propostos para as simulações . . . . . . . . . 32

3.1 Características médias dos sistemas frontais durante os três meses de verão para a Baía de Santos. . . . . . . . . . . . . . . . . . . 34

3.2 Direção (D - ${ }^{\circ}$ - convenção meteorológica) e intensidade (I - m.s ${ }^{-1}$ ) médios para 1 dia anterior a entrada de sistema frontal (-1), no dia de entrada de sistema frontal $(0)$ e próximos 3 dias subsequentes $(+1,+2$ e +3$)$ para a Baía de Santos. . . . . . . . . . . . . . . 35

4.1 Estratificação bruta $\left(\mathrm{kg} . \mathrm{m}^{-3}\right)$ nos projetos proposto, novo e antigo para os instantes de baixamar e preamar, em sizígia e quadratura, para os cenários 1, 2 e 3. B - Baixamar, P-Preamar, Q-Quadratura, S-Sizígia. . . . . . . . . . . . . . . . . . 91

4.2 Características das plumas ao final do campo próximo, para os cenários 1,2 e 3, nos projetos proposto, novo e antigo. B - Baixamar, P-Preamar, Q-Quadratura, S-Sizígia, DH - Deslocamento Horizontal, D - Diâmetro, [C] - Concentração, PP - Proposto, NV - Novo, AT -Antigo . . . . . . . . . . . . . . . . . . . . . . . . 92

4.3 Maiores extensões $(\mathrm{km})$ das plumas modeladas no campo distante, em superfície (sup.), $1 \mathrm{~m}$ e $2 \mathrm{~m}$ de profundidade em períodos de sizígia e quadratura, para os cenários 1, 2 e 3. Q-Quadratura, S-Sizígia, i 1000 ppm, ii - > 500 ppm, iii - >250 ppm e iv ->125 ppm. . . . 95 


\section{Capítulo 1}

\section{Introdução}

De acordo com Milênio (2009), atualmente as regiões costeiras englobam menos de $20 \%$ da superfície do planeta. Entretanto, contêm mais de $45 \%$ da população humana, hospedam $75 \%$ das megalópoles com mais de 10 milhões de habitantes e produzem cerca de $90 \%$ da pesca global. A região costeira se constitui em importante zona de produção de alimentos através da agropecuária, pesca e aqüicultura; é foco de desenvolvimento industrial e de transporte; fonte significativa de recursos minerais, incluindo petróleo e gás natural; principal destino turístico em todos os continentes e abundante reservatório de biodiversidade e ecossistemas, dos quais depende o funcionamento do planeta. Esta marcante presença humana nas porções litorâneas do globo pode ser observada à partir de imagens noturnas de satélites (Figura 1.1) disponibilizada por NASA (2009).

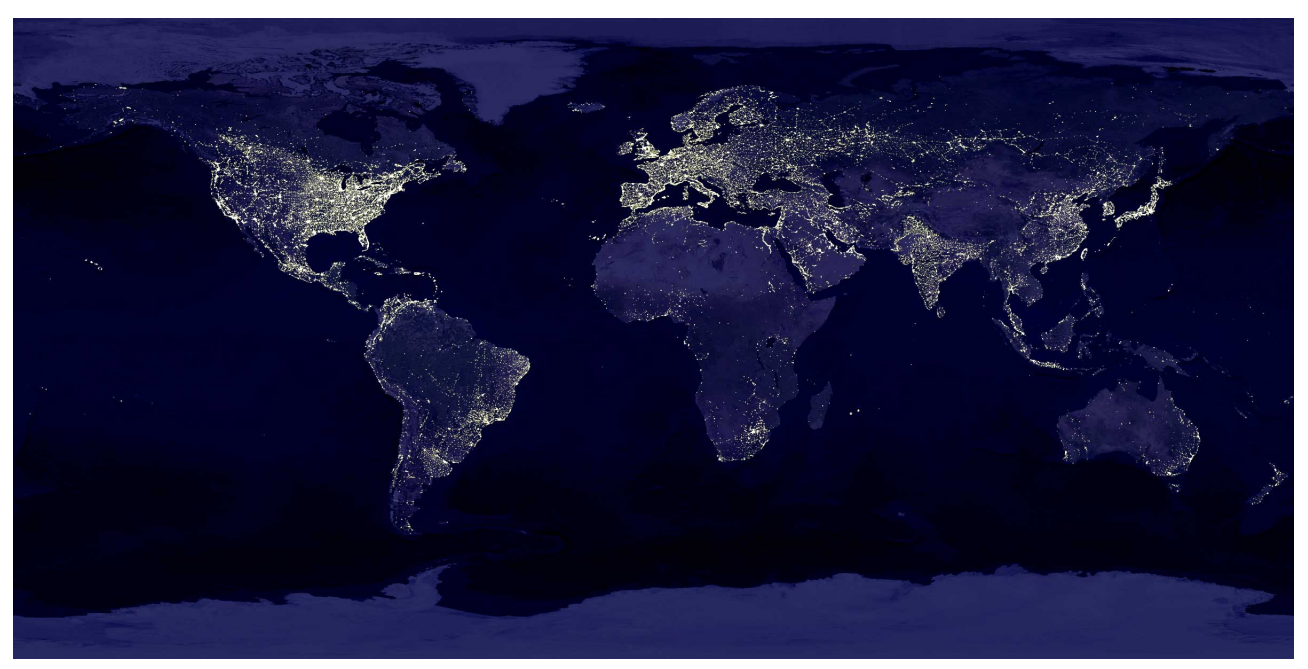

Figura 1.1: Composição de imagens de satélite noturnas ressaltando as áreas costeiras densamente povoadas (NASA 2009).

Segundo Nations (1992), um dos principais resultados da conferência Eco-92, em seu capítulo 17, que versa sobre "Proteção dos oceanos e dos mares de todo tipo, incluídos os mares fechados e semi-fechados e as zonas costeiras, e o uso racional e o 
desenvolvimento de seus recursos vivos", o parágrafo 18 diz que as fontes de origem terrestre contribuem com $70 \%$ da poluição marinha e os esgotos, nutrientes, lixo e plásticos, metais, compostos orgânicos sintéticos, entre outros, são os poluentes que apresentam maior ameaça para o meio marinho.

Segundo Clark (1995), os dois maiores tipos de poluição para a zona costeira são o lixo orgânico (esgoto) e o lixo tóxico de indústrias, que danificam ambientalmente as costas e trazem riscos à saúde humana. O autor diz ainda que a melhor solução é o descarte destes rejeitos em locais suficientemente longe de lagunas, estuários e regiões costeiras. Para este autor, o melhor custo/benefício para realizar este procedimento é fazer a descarga por meio de canos e criar um emissário submarino oceânico.

Segundo CETESB (2004), emissários submarinos são sistemas destinados a lançar os esgotos sanitários e industriais no meio marinho, visando aproveitar a grande capacidade de depuração do oceano, em função de seu enorme volume de água. O primeiro emissário do mundo foi construído em 1910 em Santa Mônica (Califórnia Estados Unidos da América).

No Brasil, existem algumas dezenas de emissários submarinos e sub-fluviais, entre os quais se destacam: Ipanema (primeiro projetado no Brasil, em 1970), Barra da Tijuca e Rio das Ostras, no Estado do Rio de Janeiro, Fortaleza, Maceió, Aracaju, Salvador, Vitória na região nordeste. No estado de São Paulo Guarujá, Santos, Praia Grande e 3 no canal de São Sebastião no estado de São Paulo.

\subsection{Eficiência, vantagens e desvantagens dos emis- sários submarinos}

Para Carvalho et al. (2002), os impactos ambientais causados por descargas de emissários submarinos são usualmente pequenos e restritos a uma pequena área ao redor do emissário e, além disso, o impacto em águas superficiais pode ser reduzido a zero devido a uma possível retenção da pluma em camadas inferiores decorrente da estratificação de densidade do oceano.

Comparando estações de tratamento secundárias e emissários submarinos, estes últimos mostram-se mais eficientes. Diluições de 1:100, comumente encontradas sobre os difusores de emissários, equivalem a um teórico tratamento com $99 \%$ de depuração, o que não é atingido pelos meios convencionais, mesmo com grandes investimentos.

A eficiência de um emissário submarino depende da combinação de recursos tecnológicos de engenharia civil hidráulica e sanitária, com o conhecimento científico adequado das condições naturais das águas receptoras. Deve ser considerada a capa- 
Tabela 1.1: Vantagens e desvantagens da implantação de emissários submarinos.

\begin{tabular}{|l|l|}
\hline Vantagens & Desvantagens \\
\hline \hline $\begin{array}{l}\text { a) eficiência na disposição e trata- } \\
\text { mento do esgoto; }\end{array}$ & $\begin{array}{l}\text { a) dificuldade na construção do } \\
\text { emissário; }\end{array}$ \\
\hline $\begin{array}{l}\text { b) não causa poluição visual e pro- } \\
\text { blemas de odor (exceto na zona de } \\
\text { mistura); }\end{array}$ & $\begin{array}{l}\text { b) danos estruturais podem ser difí- } \\
\text { ceis de reparar; }\end{array}$ \\
\hline $\begin{array}{l}\text { c) custo de capital menor ao longo } \\
\text { da vida útil; }\end{array}$ & $\begin{array}{l}\text { c) pode oferecer riscos para a nave- } \\
\text { gação e pesca; }\end{array}$ \\
\hline d) custo de manutenção menor; & $\begin{array}{l}\text { d) é difícil detectar descargas tóxicas } \\
\text { ilegais; }\end{array}$ \\
\hline $\begin{array}{l}\text { e) requer menor área para a parte } \\
\text { terrestre do emissário; }\end{array}$ & $\begin{array}{l}\text { e) pode resultar em perda potencial } \\
\text { de qualidade de água (na zona de } \\
\text { mistura); }\end{array}$ \\
\hline $\begin{array}{l}\text { f) requer poucos funcionários para a } \\
\text { operação; }\end{array}$ & $\begin{array}{l}\text { f) requer estudos de monitoramento } \\
\text { costeiro e inspeção subaquática; }\end{array}$ \\
\hline g) gasto menor em energia elétrica; & $\begin{array}{l}\text { g) pode reunir objeções de ambien- } \\
\text { talistas e outros grupos. }\end{array}$ \\
\hline $\begin{array}{l}\text { h) o problema da disposição do lodo } \\
\text { é menor; }\end{array}$ & \\
\hline $\begin{array}{l}\text { i) preservação dos rios costeiros, } \\
\text { como classe 1. }\end{array}$ & \\
\hline
\end{tabular}

cidade de assimilação do meio, os processos físicos de diluição, dispersão e qualquer outra informação que possa contribuir para o dimensionamento adequado do emissário e dos difusores. Falhas de projeto na instalação e operação de emissários podem trazer riscos ao ecossistema e à saúde humana, contaminando áreas de importância ecológica, turística, social e econômica.

Segundo CETESB (2007), e adaptado de Knill (1984), as vantagens e desvantagens da implantação de emissários submarinos podem ser resumidas de acordo com a Tabela 1.1.

\subsection{Tratamento do esgoto}

Previamente a uma disposição final de efluentes urbanos por emissário submarino, recomenda-se que haja tratamento do esgoto, para que sejam minimizados os impactos causados não só ao ser humano ou à biota mas, também, ao ecossistema como um todo. Além dos métodos físicos, onde são retiradas apenas substâncias sólidas não dissolvidas, o esgoto pode sofrer tratamentos químicos e biológicos. Essa depuração do esgoto doméstico consiste principalmente na oxidação da matéria orgânica, transformando-a em compostos mais simples como moléculas menores, sais minerais ou gases. Segundo CETESB (2002), as fases de tratamento a que o es- 
goto pode ser submetido nas estação são basicamente: tratamento preliminar ou pré-acondicionamento, tratamento primário, secundário e terciário.

No processo preliminar ou pré-acondicionamento, atuam somente alguns processos físicos de separação. Assim que o esgoto chega à estação, ele sofre gradeamento ou peneiramento, para que as partículas maiores sejam retiradas. Em geral, a malha de gradeamento varia de 4,0 a $10,0 \mathrm{~cm}$, enquanto a de peneiramento varia de $0,1 \mathrm{a}$ $1,0 \mathrm{~cm}$.

O tratamento primário, além de englobar o pré-acondicionamento, conta também com tanque de sedimentação primária, onde ocorre a decantação de outras partículas ainda restantes. Após este processo, apenas 30\% dos sólidos em suspensão permanecem no efluente.

A principal função do tratamento secundário do esgoto é reduzir a demanda bioquímica de oxigênio (DBO). Para que grandes quantidades de oxigênio do ambiente onde o esgoto será lançado não sejam consumidas com a oxidação da matéria orgânica, realiza-se a aeração em tanques nas estações de tratamento. Esses sistemas consistem na remoção dos orgânicos coloidais e dissolvidos por ação biológica, com posterior decantação.

O tratamento terciário ou avançado é mais utilizado para efluentes industriais, sendo integrado por vários sistemas específicos, como precipitação induzida, adsorsão por carbono ativado, sistemas complexos de filtração, oxidação química, entre outros. Sua função é remover substâncias inorgânicas, nutrientes, orgânicos persistentes, metais e também baixar drasticamente a DBO. Este tratamento também pode ser aplicado a efluentes domésticos.

Cabe ressaltar que os sistemas de tratamentos descritos representariam uma estação de tratamento de esgoto ideal, não significando que as estações possuam toda a seqüência descrita. Alguns autores afirmam que, para a disposição final de efluentes urbanos através de emissários, seria necessário somente o tratamento primário (Occhipinti 1970).

\subsection{Processos de mistura do efluente no meio ma- rinho}

Os processos de mistura de descargas contínuas em um corpo receptor podem ser divididos em três zonas, de acordo com suas respectivas escalas de tamanho e tempo (Figura 1.2).

$\mathrm{Na}$ vizinhança imediata da descarga, o efluente penetra no ambiente na forma de jato, sendo a trajetória e a mistura governada pela velocidade de injeção, pelo empuxo e pela geometria do emissário (difusores). Esta zona de mistura inicial é 

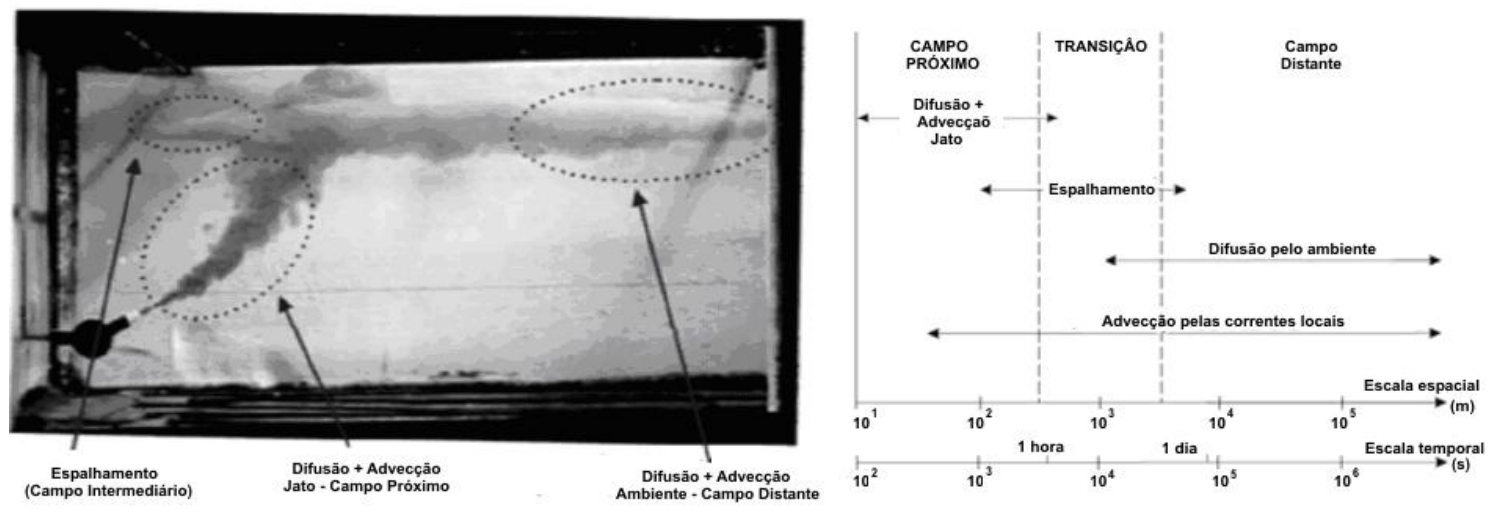

Figura 1.2: No painel da esquerda, ensaio laboratorial de uma descarga em um corpo de água com estratificação. No painel da direita, escalas espaciais e temporais dos processos envolvidos. Modificado de Jirka et al. (1976).

chamada de campo próximo ("near-field"), tem escala espacial da ordem de 10 a 100 metros e inclui interações com a superfície, fundo e picnoclina. As características dos difusores podem afetar diretamente a mistura inicial no campo próximo (Hillerbrand 2003). A escala temporal é da ordem de segundos a minutos.

A influência dos processos físicos do campo próximo decresce conforme o efluente se afasta do ponto de lançamento. Progressivamente, o jato perde a quantidade de movimento inicial e aproxima-se de um nível de equilíbrio hidrostático. Esse nível pode ser a superfície livre ou alguma profundidade intermediária, dependendo da diferença de densidade entre o efluente e o meio ambiente. A partir dessa região, o efluente comporta-se como uma pluma. A dispersão da pluma é controlada pela advecção e pela difusão. Esta zona é classificada como campo distante ("far-field"). Comparada com o campo próximo, a diluição nesta região é muito menor. Sua escala espacial é de quilômetros a dezenas de quilômetros e sua escala temporal é da ordem de horas a dias.

Entre essas duas regiões, existe uma região de estabilização. A dinâmica desta região intermediária depende tanto do momento e do empuxo da descarga quanto das correntes presentes no local.

\subsubsection{Campo próximo}

Nesta seção, serão descritos os fenômenos físicos predominantes no campo próximo. Na zona de mistura inicial, o efluente entra em contato vigorosamente com a água do ambiente, misturando-se à ela. Três importantes tipos de processos ocorrem no campo próximo: mistura provocada pelo empuxo positivo do jato, interações com os limites e mistura na camada superficial. Estes processos serão descritos nos parágrafos abaixo.

Mistura provocado pelo empuxo positivo do jato: O movimento do 
efluente proveniente de descarga submersa provoca perturbações no campo de velocidade do ambiente. De modo geral, aparecem acelerações verticais devidas à combinação da velocidade de injeção do efluente e do fluxo de empuxo decorrente da mistura turbulenta.

Os efluentes, principalmente os domésticos, normalmente possuem densidade próxima à da água doce. Com isto, sua densidade é muito menor que a densidade da água do mar e consequentemente apresenta empuxo positivo. Os jatos tendem a perder profundidade até encontrarem um nível de equilíbrio hidrostático ou a superfície livre. Nesta trajetória, o fluído misturar-se com a água do meio. Velocidades diferentes entre aquela de injeção do efluente e a do meio provocam uma camada de descontinuidade entre ambos os fluidos. Na parte interna do efluente, muitos vórtices pequenos são formados devido à esta descontinuidade, no processo chamado de entranhamento. A mistura entre o efluente e o meio, devida ao entranhamento, dilui o primeiro, isto é, diminui a concentração do efluente. Esta primeira parte no processo de diluição decresce rapidamente com o aumento da distância da fonte.

As correntes marinhas gradualmente defletem o jato em sua direção predominante. A água do mar pode apresentar estratificação, provocada por variações verticais de temperatura ou salinidade. Em muitos casos, o jato fica retido em um determinado nível devido a esta estratificação de densidade, fazendo com que as acelerações verticais fiquem próximas a zero. Neste ponto, a aproximação hidrostática pode ser assumida, a mistura provocada pelo empuxo positivo do jato cessa, e dá-se o fim do campo próximo, iniciando-se o campo distante.

Interações com os limites: Os limites verticais do oceano são o fundo e a superfície livre. Em alguns casos, podem haver limites internos, como a picnoclina. Picnoclinas são camadas onde a densidade aumenta rapidamente com o aumento da profundidade. Dependendo das características dinâmicas e geométricas da descarga, variados processos de interação com os limites podem ocorrer. Um exemplo é o processo decorrente da descarga de um efluente próximo ao fundo, comparado com um efluente que se desloca livremente (Figura 1.3). Esse processo de interação com o fundo promove uma transição entre a mistura provocada pelo empuxo positivo do jato no campo próximo e dispersão característica do campo distante. Esta transição pode ser gradual ou abrupta, podendo ainda diminuir o tamanho do campo próximo.

Mistura superficial provocado pelo empuxo positivo do jato: jatos que atingem a superfície livre do mar podem sofrer entranhamento nessa 

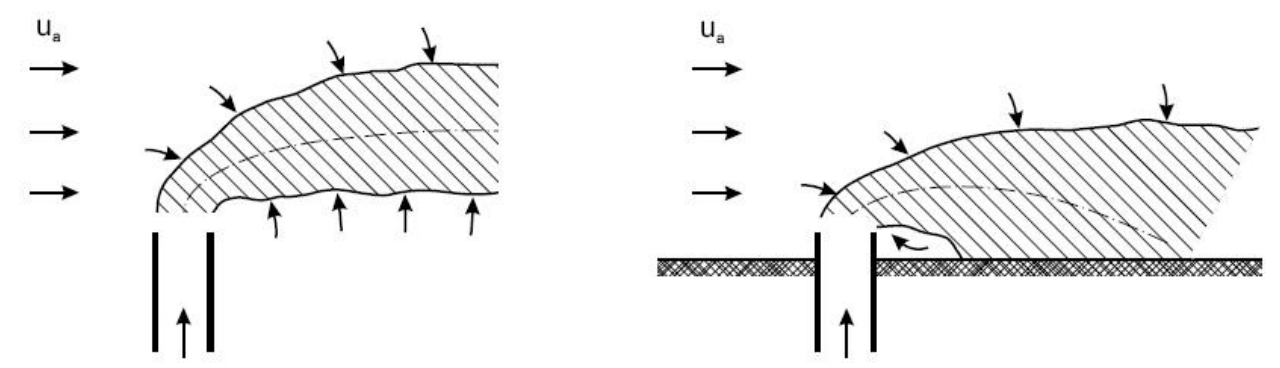

Figura 1.3: No painel da esquerda, efluente que se desloca livremente sem interação com o fundo. No painel da direita, efluente interagindo com o fundo. Fonte: Jirka et al. (1976).

região. A velocidade do meio é diminuída bruscamente pelo efluente na superfície, provocando a formação de pequenos vórtices em seu interior, fazendo com que o processo de mistura seja acelerado.

\subsubsection{Campo distante}

Nesta seção, descreveremos os principais processos físicos na mistura de efluentes no campo distante. Os processos no campo distante são causados principalmente pela advecção horizontal do efluente, devida à velocidade atual do ambiente, e pela difusão gerada pela turbulência do corpo d’água.

Durante o estabelecimento da pluma no final do campo próximo, é construído um gradiente horizontal de pressão que tende a espalhar o efluente horizontalmente. Daí a pluma é advectada pelas correntes marinhas. Este processo pode ocorrer tanto na superfície quanto em outra profundidade na qual houve a estabilização da pluma.

Difusão passiva causa, em geral, aumento da largura e da espessura da pluma até que ela interaja com algum contorno. A taxa de difusão ambiental depende principalmente das características dinâmicas e do grau de estratificação do ambiente. Em áreas litorâneas, a difusividade é também dependente do tamanho da pluma.

\subsubsection{Modelagem numérica da mistura de efluentes no meio marinho}

Uma técnica bastante utilizada atualmente, para o estudo da dinâmica de regiões costeiras e de plumas de efluentes, é a aplicação de métodos numéricos para a solução de equações governantes. A modelagem numérica da mistura de efluentes provenientes de emissários é uma importante ferramenta para diagnósticos e prognósticos. Modelos computacionais permitem simular e prever impactos ambientais para ambos domínios vizinhos da descarga: campo próximo e campo distante. Os modelos de campo próximo são suítes que simulam os processos de mistura nessa 
região. Já os modelos de campo distante são usados para descrever a dispersão dos efluentes em áreas costeiras e estuarinas (Hillerbrand 2003).

Hoje em dia, um dos maiores desafios é o acoplamento de modelos de campo próximo e campo distante. Zhang (1995), Hillerbrand (2003) e Bleninger \& Jirka (2004) apresentaram trabalhos desenvolvem esta metodologia.

\section{Etapas da modelagem}

Na Figura 1.4 é observado um esquema simplificado das etapas de modelagem numérica da mistura do efluente de um emissário submarino. Primeiramente, é realizada a modelagem hidrodinâmica da região. Como resultado, são obtidas séries temporais de perfis de densidade e velocidade na região de lançamento dos efluentes. Com estes, associados às características do emissário e da injeção, utilizando-se modelos de campo próximo, as características de diluição, tamanho e profundidade da pluma estabelecida no final deste são obtidas. Estes resultados, adicionados aos experimentos hidrodinâmicos, servem de forçantes para o modelo de qualidade de água, onde são estudadas a diluição e a dispersão no campo distante. Não há trabalhos publicados que apresentem o acoplamento numérico de ambos os campos em um único modelo. Nesta Dissertação, acoplaremos os resultados de diversos modelos numéricos, como é prática usual.

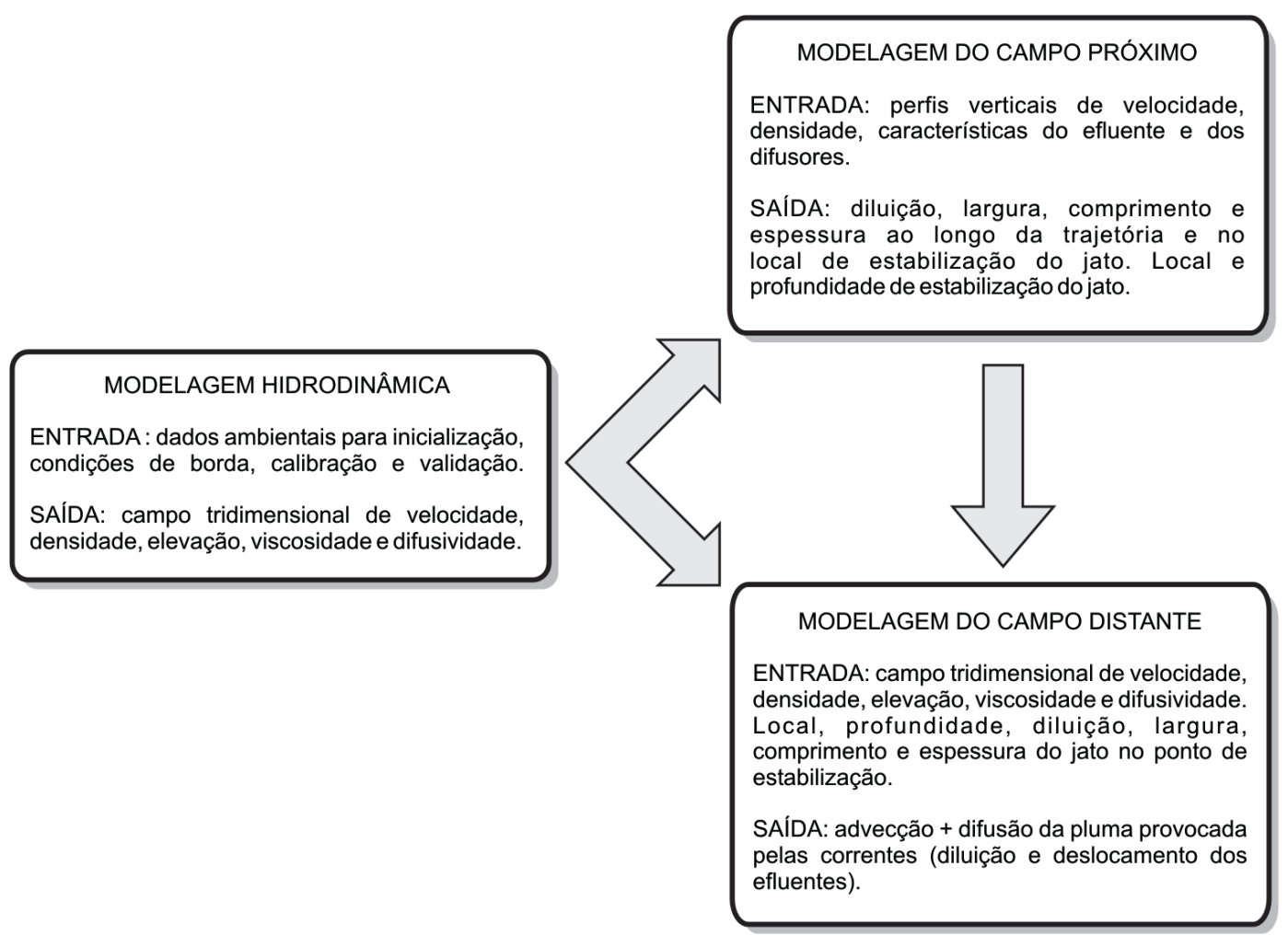

Figura 1.4: Processos envolvidos na modelagem numérica da diluição de efluentes de emissários submarinos. 
A parte que ainda requer muitos estudos é a interface entre os modelos de campo próximo e distante (seta para baixo na Figura 1.4). As principais dificuldades estão em acoplar os resultados pertinentes à carga e a geometria da pluma, previstos pelo modelo de campo próximo, à grade imposta para o modelo de campo distante, além dos efeitos dinâmicos gerados pela descarga de efluentes.

\subsection{Região de interesse: Baía de Santos}

A região de estudo é a Baía de Santos (BS), localizada na porção central da costa do Estado de São Paulo, entre as latitudes $23,95^{\circ} \mathrm{S}$ e $24,05^{\circ} \mathrm{S}$ e as longitudes $46,27^{\circ} \mathrm{O}$ e $46,40^{\circ} \mathrm{O}$, tendo como limites os municípios de Santos, São Vicente, Guarujá e Praia Grande (Figura 1.5). Juntamente com Cubatão, Bertioga, Itanhaém, Mongaguá e Peruíbe, estes municípios formam a Região Metropolitana da Baixada Santista. Na BS está localizado o emissário submarino de Santos (ESS).
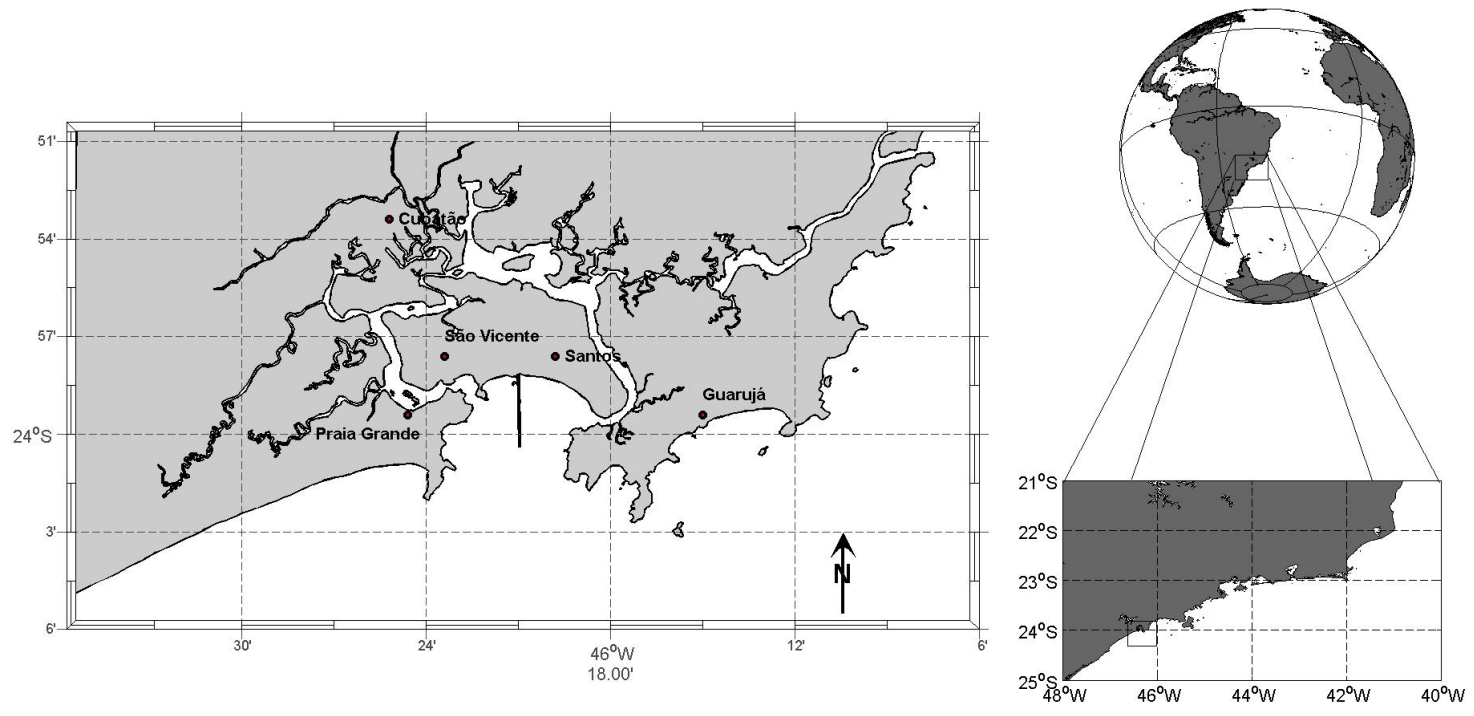

Figura 1.5: Localização geográfica da Baía de Santos e os principais municípios situados no entorno da mesma. O emissário submarino de Santos está indicado na figura pela reta preta.

A BS possui largura na parte central de $7 \mathrm{~km}$, sendo que na sua entrada este valor é aumentado para $11 \mathrm{~km}$. O limite a oeste é a Ponta de Itaipu, enquanto que na porção leste seu limite é a Ponta da Macumba (Figura 1.6) (CETESB 2005). A BS recebe águas estuarinas provenientes de dois canais, do lado oeste o Canal de São Vicente (CSV) e do lado leste o Canal do Porto (CP). Ambos canais desaguam na BS em sua porção interior. Além destes canais, o complexo estuarino de Santos apresenta o Canal de Bertioga (CB), que está situado entre a Ilha de Santo Amaro 
(Guarujá) e o continente. A porção mais ao norte do sistema estuarino de Santos será designada nesta dissertação como Alto Estuário Santista (AES). Todas as feições aqui descritas podem ser observadas na Figura 1.6, desenvolvida a partir de imagens LandSat (projeto desenvolvido pela Agência Espacial Americana dedicado exclusivamente à observação dos recursos naturais terrestres) disponibilizadas pelo programa Brasil Visto do Espaço, da Empresa Brasileira de Pesquisa Agropecuária (EMBRAPA) no página da internet www.cdbrasil.cnpm.embrapa.br.

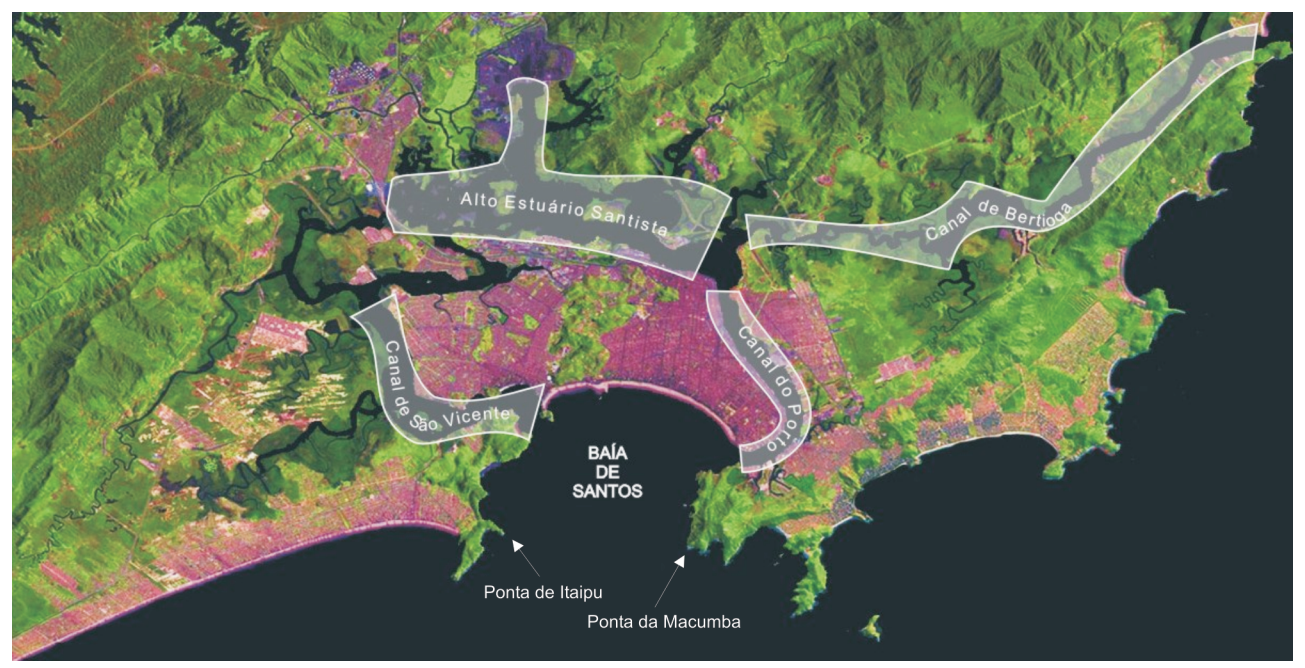

Figura 1.6: Complexo estuarino da baixada santista. Em destaque as principais feições citadas neste trabalho. Composição de imagens LandSat (Miranda \& Coutinho $2004)$.

Durante o verão, a BS apresenta alta estratificação, com temperaturas variando entre $21,58^{\circ} \mathrm{C}$ e $28,40^{\circ} \mathrm{C}$ e salinidades variando entre 29,09 e 35,08 . Durante o inverno, os gradientes diminuem, tornando a coluna mais homogênea, com valores de temperatura (salinidade) variando entre $17,56^{\circ} \mathrm{C}(32,4)$ e $22,85^{\circ} \mathrm{C}(34,89)$, conforme CETESB (2004), Bosquilha (2002), Andutta et al. (2006) e David (2003).

Segundo Harari \& Camargo (1998), as principais forçantes que influenciam a circulação na BS são os gradientes baroclínicos de pressão causados pelas descargas fluviais dos dois principais canais existentes (CP e CSV), as marés e os vento sinóticos. Ainda segundo estes autores, a geomorfologia de fundo também apresenta papel fundamental na circulação da BS.

Em situação de maré alta, há correntes superficiais em direção ao mar aberto na porção mediana da BS. Já em situação de baixamar, há evidências de ocorrência de movimentos antihorários no interior da BS, decorrentes principalmente da geomorfologia de fundo e do efeito dinâmico do fluxo do CP (Fúlvaro \& Ponçano (1976) apud Marques (2006)). A onda de maré apresenta co-oscilação com período semidiurno, propagando-se simultaneamente pelos CP, CSV e CB, com amplitudes variando entre 0,27 m em situação de quadratura e 1,23 m em sizígia (Harari et al. 
$2000)$.

A região da Baixada Santista forma um grande balneário turístico no qual, tanto em feriados quanto no período de férias, a população aumenta consideravelmente. Juntamente com este aumento, problemas decorrentes do saneamento ficam agravados. No final da década de 60, o sistema sanitário apresentava capacidade esgotada, o que levava à crescente rejeição de Santos como local de veraneio e à decorrente queda de receita advinda do turismo. Para reverter esta situação, em 30 de junho de 1969 foi encaminhado à Secretaria dos Serviços e Obras Públicas do Estado de São Paulo o Plano Diretor de Esgotos das Cidades de Santos e São Vicente, preconizando a disposição oceânica dos esgotos e a construção do emissário submarino na Praia de José Menino, com extensão de cerca de $4.007 \mathrm{~m}$. Iniciava-se assim a utilização de disposição oceânica de esgoto sanitário como uma alternativa para o tratamento de efluentes no litoral paulista (CETESB 2007).

\subsection{O emissário submarino de Santos}

O ESS, que entrou em operação em 1979, foi construído pela Companhia de Saneamento Básico do Estado de São Paulo (SABESP) em tubos de aço com diâmetro externo de $1,75 \mathrm{~m}$, revestidos externamente de concreto (CETESB 2007). O projeto original do ESS possuía extensão de 4.007 m e profundidade de lançamento dos efluentes de aproximadamente $10 \mathrm{~m}$. Os $200 \mathrm{~m}$ finais do emissário foram projetados para ter 40 difusores do tipo riser, subindo cerca de $0,50 \mathrm{~m}$ do fundo, espaçados a cada 5,3 m e com diâmetro de $0,3 \mathrm{~m}$, operando com vazão total de $3,5 \mathrm{~m}^{3} / \mathrm{s}$.

Para o segundo semestre do ano de 2009, com a aprovação de novo projeto, o ESS ganhou 400 m de extensão, com mais 80 difusores, mantendo o espaçamento de 5,3; a vazão total de operação será aumentada para $5,3 \mathrm{~m}^{3} / \mathrm{s}$ (informação verbal) 1 .

Antes de ser lançado no mar, o esgoto coletado é encaminhado para a Estação de Pré-Condicionamento, onde é submetido a gradeamento, peneiramento e desinfecção por cloro. Esse emissário, além de receber as contribuições dos coletores de esgotos, recebe também as águas dos canais de drenagem (CETESB 2007). Segundo esta última fonte a densidade do efluente é de $998 \mathrm{~kg} / \mathrm{m}^{3}$.

Sobre a modelagem da pluma do ESS, pouco foi estudado até o momento. Os principais resultados são encontrados em CETESB (2007). Nesse trabalho, apenas o campo próximo foi modelado, em duas situações, abrangendo as características de projeto do emissário e as características reais de operação. Foi usada uma corrente média, com estratificação linear das águas na região do lançamento de efluentes.

Marques (2006) acoplou um modelo hidrodinâmico e de campo próximo, asso-

\footnotetext{
${ }^{1}$ Informação cedida pelo Eng. João Guedes Neto, gerente do setor de coleta e tratamento de esgotos da SABESP, em Santos, 2009.
} 
ciado a um modelo ecotoxicológico, para observar a distribuição e mortalidade de larvas de ouriço de acordo com a concentração de efluente. Foram realizados quatro experimentos, sendo dois em período de verão e dois em período de inverno, com características médias encontradas nos respectivos dias.

O modelo físico da Baía e Estuário de Santos e São Vicente do Laboratório de Hidráulica da Escola Politécnica da USP foi utilizado para a avaliação de diversos cenários de dispersão de uma pluma de efluente nas áreas dos ESS e Praia Grande - Ponta de Itaipu. Para tanto, foram realizados ensaios qualitativos utilizando-se o traçador colorimétrico azul de metileno. Os ensaios realizados correspondem apenas à condição de dispersão no campo distante, não reproduzindo os efeitos da diluição inicial nem os efeitos de vento e de onda, reproduzindo apenas o efeito da maré (CETESB 2007). 


\subsection{Objetivos}

Segundo CETESB (2007), sobre o ESS:

Embora tenha havido um grande desenvolvimento nesta área, há ainda muitas dúvidas no entendimento básico e na implementação prática. Há interações complexas e interrelações desconhecidas a serem consideradas, por exemplo, a descarga como um jato simples e sua interação sucessiva com outros jatos de um difusor múltiplo e, em seguida, o processo de mistura nos campos próximo e distante.

A hipótese científica deste trabalho é que o acoplamento do campo próximo e distante, nunca aplicado especificamente para o estudo da dispersão da pluma do ESS, conduzirá a resultados mais realistas para a dispersão da pluma de esgotos, visto que sua total diluição não ocorre somente no campo próximo (os principais trabalhos de modelagem da pluma do ESS contemplam somente esta etapa da diluição). Assim, o objetivo principal desta Dissertação de Mestrado é acoplar os modelos de campo próximo e distante no estudo da dispersão da pluma de efluentes lançado pelo ESS.

Os objetivos específicos são:

1. Verificar se a pluma de esgoto modelada atinge a costa da Baixada Santista;

2. Verificar se as alterações propostas para o ESS contribuirão para melhoria da qualidade das águas litorâneas da Baixada Santista. 


\section{Capítulo 2}

\section{Métodos}

Neste capítulo, primeiramente serão descritos os métodos para a execução da modelagem hidrodinâmica, seguido pela modelagem do campo próximo e, finalmente a metodologia empregada na modelagem do campo distante. Serão apresentadas ainda as metodologias para o acoplamento dos modelos de campo próximo e distante para o ESS.

\subsection{Modelagem hidrodinâmica}

A descrição de processos hidrodinâmicos no oceano é baseada nas leis de conservação: conservação de momento (equação do movimento), conservação da massa (equação da conservação de massa), conservação da massa parcial (equação da difusão do sal) e conservação do calor (equação da energia ou equação da condução de calor) e, adicionalmente, se considera a equação do estado para a água do mar. Dessa forma, tem-se um sistema de sete equações a sete incógnitas, com quatro variáveis independentes - as três coordenadas espaciais $x, y$ e $z$ e o tempo $t$. O sistema de equações inclui, portanto, as seguintes sete variáveis dependentes: as componentes de corrente $u, v$ e $w$ (segundo os eixos $x, y$ e $z$ ), a pressão $p$, a densidade $\rho$, a salinidade $S$ e a temperatura $T$.

Na sua forma geral o sistema de equações é não linear. Soluções unicamente determinadas podem existir somente se, em adição, condições iniciais e de contorno forem fornecidas.

Sendo $f_{0}$ o parâmetro de Coriolis, $A_{h}$ e $A_{v}$ os coeficientes de difusão turbulenta horizontal e vertical de momento, $g$ a aceleração da gravidade, $A_{s h}$ e $A_{s v}$ os coeficientes de difusão turbulenta horizontal e vertical da salinidade e $A_{t h}$ e $A_{t v}$ os coeficientes de difusão turbulenta horizontal e vertical de calor, para um sistema de coordenadas com origem na superfície sem distúrbios, com $x$ apontando para leste, $y$ para norte e $z$ para cima, a forma geral das equações é, sob as aproximações de Boussinesq, do plano f, desprezando as parcelas referentes à esfericidade em $2.3 \mathrm{e}$, 
também, as acelerações de Coriolis proporcionais à $\cos \theta$, sendo $\theta$ a latitude:

$$
\begin{gathered}
\frac{\partial u}{\partial t}+u \frac{\partial u}{\partial x}+v \frac{\partial u}{\partial y}+w \frac{\partial u}{\partial z}-f_{0} v=-\frac{1}{\rho} \frac{\partial p}{\partial x}+A_{h}\left(\frac{\partial^{2} u}{\partial x^{2}}+\frac{\partial^{2} u}{\partial y^{2}}\right)+A_{v}\left(\frac{\partial^{2} u}{\partial z^{2}}\right) \\
\frac{\partial v}{\partial t}+u \frac{\partial v}{\partial x}+v \frac{\partial v}{\partial y}+w \frac{\partial v}{\partial z}+f_{0} u=-\frac{1}{\rho} \frac{\partial p}{\partial y}+A_{h}\left(\frac{\partial^{2} v}{\partial x^{2}}+\frac{\partial^{2} v}{\partial y^{2}}\right)+A_{v}\left(\frac{\partial^{2} v}{\partial z^{2}}\right) \\
\frac{\partial w}{\partial t}+u \frac{\partial w}{\partial x}+v \frac{\partial w}{\partial y}+w \frac{\partial w}{\partial z}=-\frac{1}{\rho} \frac{\partial p}{\partial z}-g+A_{h}\left(\frac{\partial^{2} w}{\partial x^{2}}+\frac{\partial^{2} w}{\partial y^{2}}\right)+A_{v}\left(\frac{\partial^{2} w}{\partial z^{2}}\right) \\
\frac{\partial \rho}{\partial t}+\frac{\partial}{\partial x}(\rho u)+\frac{\partial}{\partial y}(\rho v)+\frac{\partial}{\partial z}(\rho w)=0 \\
\frac{\partial S}{\partial t}+u \frac{\partial S}{\partial x}+v \frac{\partial S}{\partial y}+w \frac{\partial S}{\partial z}=A_{s h}\left(\frac{\partial^{2} S}{\partial x^{2}}+\frac{\partial^{2} S}{\partial y^{2}}\right)+A_{s v}\left(\frac{\partial^{2} S}{\partial z^{2}}\right)+F_{s} \\
\frac{\partial T}{\partial t}+u \frac{\partial T}{\partial x}+v \frac{\partial T}{\partial y}+w \frac{\partial T}{\partial z}=A_{t h}\left(\frac{\partial^{2} T}{\partial x^{2}}+\frac{\partial^{2} T}{\partial y^{2}}\right)+A_{t v}\left(\frac{\partial^{2} T}{\partial z^{2}}\right)+F_{t} \\
\rho=\rho(S, T, p)
\end{gathered}
$$

onde $F_{s}$ e $F_{t}$ são fontes ou sorvedouros de sal ou calor e o parâmetro de Coriolis $f_{0}$ é definido em função da velocidade angular de rotação da Terra $\Omega\left(\Omega=7,292.10^{-5}\right.$ $\mathrm{rad} / \mathrm{s}$ ) e de $\theta$ como

$$
f_{0}=2 \Omega \operatorname{sen} \theta
$$

No sistema de equações hidrodinâmicas básicas 2.1 à 2.7, as equações 2.1 a 2.3 correspondem às componentes da equação do movimento segundo as direções $x, y$ e $z$, respectivamente, 2.4 é a equação da conservação de massa, 2.5 é a equação da difusão do sal, 2.6 é a equação da condução de calor e 2.7 é a equação do estado.

Para o estudo hidrodinâmico da região de interesse será empregada uma suíte computacional totalmente modular desenvolvida pela WL | Delft Hydraulics, Holanda. Além do módulo hidrodinâmico, é possível acoplar um modelo de qualidade de água, utilizado para simular o campo distante.

O modelo hidrodinâmico, denominado DELFT3D - FLOW, é um modelo de si- 
mulação multidimensional que calcula escoamentos e transportes não estacionários forçados por descargas fluviais, marés e processos meteorológicos em regiões costeiras, estuarinas e rios. Emprega uma grade horizontal curvilínea, facilmente ajustada aos contornos sólidos da região modelada, facilitando a representação de margens de rios, por exemplo. Suporta, como coordenadas verticais, a transformação conhecida na literatura por sigma $(\sigma)$ introduzida por Phillips (1957), resultando numa representação suave da topografia de fundo. Com $z$ sendo a coordenada vertical, $\varphi$ a elevação da superfície livre e $H$ a profundidade total da coluna de água, o sistema coordenado $\sigma$ é definido por:

$$
\sigma=\frac{z-\varphi}{H}
$$

Os fluxos calculados pelo DELFT3D-FLOW podem ser forçados por marés, gradientes de densidade, tensão de cisalhamento do vento e gradientes de pressão atmosférica. Fontes e sorvedouros são incluídos na equação do movimento, simulando algum tipo de descarga, como por exemplo rios.

O modelo DELFT3D-FLOW resolve as equações hidrodinâmicas aproximadas para águas rasas. Essa aproximação sugere que a profundidade é assumida muito menor que a escala horizontal do movimento. Pela razão de aspecto ser pequena, a aproximação de águas rasas é válida, e a equação do movimento em sua componente vertical é resumida ao equilíbrio hidrostático. Com isto, é assumido que a aceleração vertical é muito pequena comparada com a gravidade reduzida e esta é desprezada nas equações. Por essa razão, esse modelo só pode ser usado para simular dispersões de efluentes nos campos distantes, onde estes processos são hidrostáticos. Além disso, o DELFT3D-FLOW apresenta as seguintes características:

- Na camada de fundo, o efeito do atrito é parametrizado em ordem quadrática;

- A formulação que assume a tensão de cisalhamento provocada pelo fundo em combinação com as correntes é baseada num campo bidimensional de fluxos, gerada à partir de velocidades próximas ao fundo usando uma aproximação logarítmica;

- Os pontos de grade podem ser assumidos como sendo secos quando a profundidade é menor que o descrito para a batimetria. Neste caso, a velocidade neste ponto de grade é considerada como sendo zero. Em instantes de tempo posteriores esta célula pode voltar a ser considerado ponto de grade úmido, de acordo com o nível em relação à batimetria.

À partir das aproximações descritas, as equações hidrodinâmicas básicas 2.1 à 2.7 são modificadas. Tais equações modificadas, utilizadas pelo DELFT3D-FLOW, são apresentadas no Apêndice A. 
Foi empregada uma grade numérica ortogonal curvilínea, com resolução variável, estendendo-se entre as longitudes de $46^{\circ} \mathrm{W}$ a $46^{\circ} 36^{\prime} \mathrm{W}$ e as latitudes de $23^{\circ} 50^{\prime} \mathrm{S}$ a $24^{\circ} 15^{\prime} \mathrm{S}$, abrangendo o complexo estuarino que envolve a BS (Figura 2.1). As características de forma da grade (tamanho e resolução) são apresentadas na Tabela 2.1.

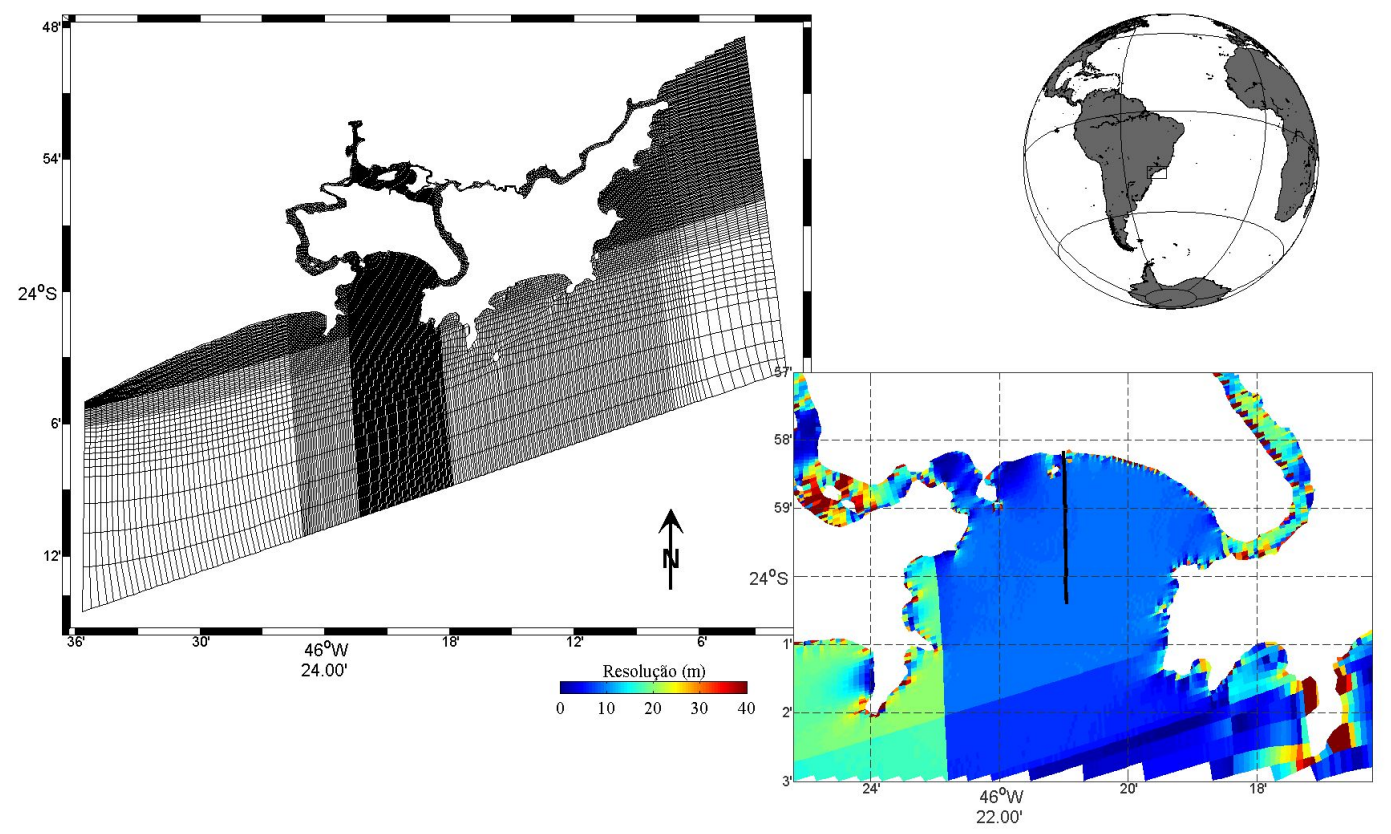

Figura 2.1: Representação gráfica da grade utilizado nas simulações hidrodinâmicas. No menor painel, detalhe da resolução próxima ao local do emissário submarino de Santos.

Tabela 2.1: Características gerais da grade utilizada nas simulações hidrodinâmicas.

\begin{tabular}{|c|c|}
\hline Dimensão horizontal & 324 X 223 \\
\hline Dimensão vertical & 15 camadas \\
\hline Resolução máxima horizontal & $10 \mathrm{~m}$ \\
\hline Resolução mínima horizontal & $1000 \mathrm{~m}$ \\
\hline
\end{tabular}

A resolução das 15 camadas verticais variou da seguinte maneira, em porcentagem, da superfície em direção ao fundo: $2,3,4,5,7,9,13,14,13,9,7,5,4,3$ e $2 \%$. Desta maneira, as camadas limites de superfície e fundo apresentam maior resolução quando comparadas à camada intermediária. Uma representação gráfica desta resolução vertical pode ser observada na Figura 2.2 .

A batimetria interpolada foi obtida através das cartas náuticas 1701 (Porto de Santos) e 1711 (Proximidades do Porto de Santos), da Diretoria de Hidrografia e Navegação da Marinha do Brasil, atualizadas em 22/07/2008 e 8/10/2008, respectivamente. A batimetria utilizada pode ser observada na Figura 2.3

As bordas abertas foram determinadas para justificar a utilização de dois tipos de forçantes: descarga de rios da região estuarina e co-oscilação da maré astronômica. 


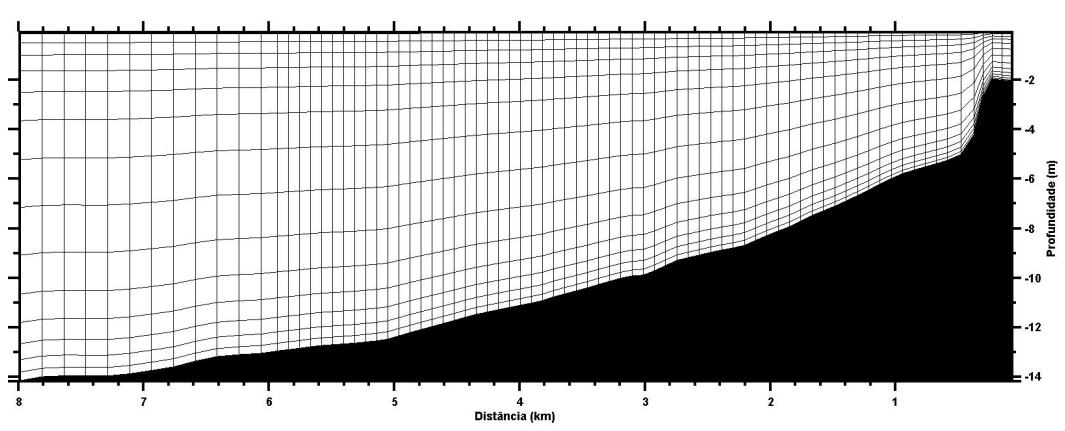

Figura 2.2: Representação gráfica da resolução vertical adotada na simulação hidrodinâmica.

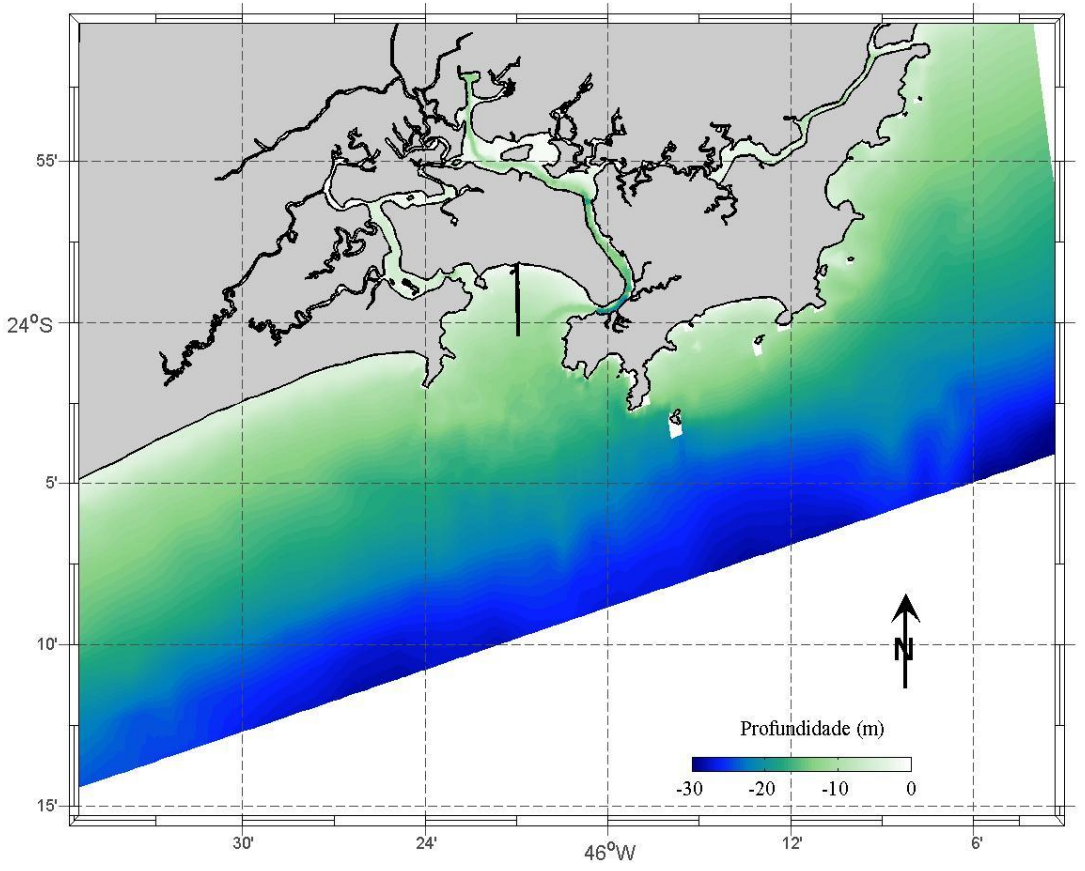

Figura 2.3: Batimetria interpolada utilizada nas simulações hidrodinâmicas.

As bordas localizadas na parte oceânica (Figura 2.1) serão designadas como oeste, sul e leste, de acordo com sua orientação geográfica.

As constantes harmônicas nas bordas abertas foram obtidas do modelo global de marés TPXO 6.2. Comparando-se dados costeiros em que são conhecidas as constantes harmônicas, como por exemplo estações maregráficas catalogadas em FEMAR (2000), com os resultados do modelo, verifica-se ótima concordância, justificando a utilização dos resultados desse modelo nos contornos abertos. O TPXO é um modelo global de marés que assimila dados provenientes de altímetros (satélites TOPEX/Poseidon e Jason). Os métodos utilizados por este modelo podem ser obtidos em detalhe em Egbert et al. (1994). As componentes que estão disponíveis na versão 6.2 são: $M_{2}, S_{2}, N_{2}, K_{2}, K_{1}, O_{1}, P_{1}, Q_{1}, M_{f}$ e $M_{m}$, com resolução de 
Tabela 2.2: Constantes harmônicas descritas para as bordas abertas oceânicas. Os valores listados correspondem à amplitude (Amp.) $(\mathrm{m}) \mid$ fase $\left(^{\circ}\right)$ relativos a Greenwich.

\begin{tabular}{|c|c|c|c|c|c|c|}
\hline Harmônico & \multicolumn{2}{|c|}{ Sul } & \multicolumn{2}{c|}{ Oeste } & \multicolumn{2}{c|}{ Leste } \\
\hline \hline & Amp. $[\mathrm{m}]$ & ${\text { Fase }\left(^{\circ}\right)}^{\circ}$ & Amp. $[\mathrm{m}]$ & Fase $\left(^{\circ}\right)$ & Amp. $[\mathrm{m}]$ & Fase $\left(^{\circ}\right)$ \\
\hline$M_{2}$ & 0,34 & 163,7 & 0,35 & 162,9 & 0,33 & 164,3 \\
\hline$S_{2}$ & 0,23 & 176,3 & 0,24 & 175,9 & 0,22 & 176,6 \\
\hline$N_{2}$ & 0,05 & 208,3 & 0,05 & 209,7 & 0,04 & 205,5 \\
\hline$K_{2}$ & 0,06 & 169,0 & 0,06 & 169,4 & 0,06 & 169,4 \\
\hline$K_{1}$ & 0,06 & 188,4 & 0,06 & 188,4 & 0,06 & 188,6 \\
\hline$O_{1}$ & 0,11 & 120,4 & 0,11 & 120,0 & 0,11 & 128,9 \\
\hline$P_{1}$ & 0,02 & 171,5 & 0,02 & 171,1 & 0,02 & 171,9 \\
\hline$Q_{1}$ & 0,03 & 101,2 & 0,03 & 101,5 & 0,03 & 161,0 \\
\hline$M_{f}$ & 0,01 & 336,2 & 0,01 & 335,1 & 0,01 & 337,5 \\
\hline
\end{tabular}

$0,25^{\circ}$. As amplitudes e fases relativas a cada componente, e em cada uma das bordas abertas (ponto central), podem ser visualizadas na Tabela 2.2 .

As descargas dos rios de maior porte (Figura 2.4) foram especificadas como condições de contorno, a partir de Miranda et al. (2007), conforme resumido na Tabela 2.3 .

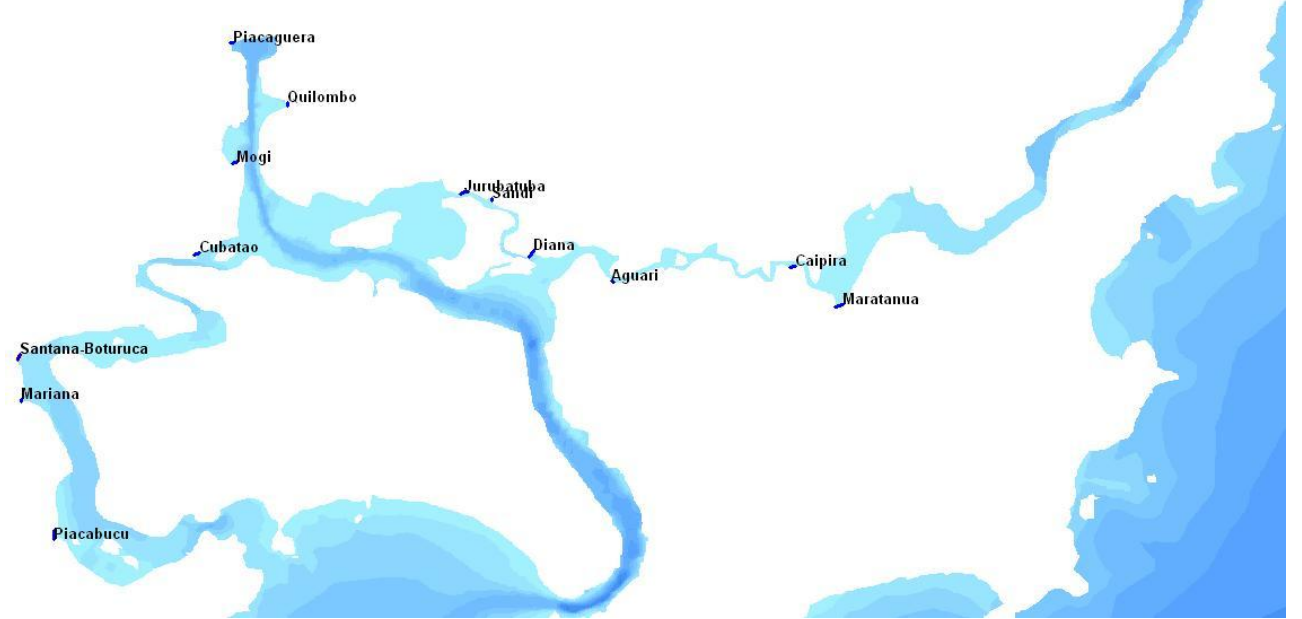

Figura 2.4: Localização dos principais rios na baixada santista, considerados nas simulações hidrodinâmicas.

As características de temperatura e salinidade foram especificadas para o verão devido à maior complexidade da estrutura vertical. Para a região da plataforma continental adjacente à BS, a climatologia adotada para condição inicial foi a desenvolvida por Rezende (2003). As representações horizontais e verticais (na radial de Santos) para temperatura e salinidade, adaptadas de Rezende (2003), podem ser observados nas Figuras 2.5 e 2.6. 
Tabela 2.3: Vazão imposta nas bordas abertas continentais simulando os principais rios da baixada santista, obtido de Miranda et al. (2007).

\begin{tabular}{c|c} 
Rio & Vazão $\left(\mathrm{m}^{3} \cdot \mathrm{s}^{-1}\right)$ \\
\hline Itapanhaú & 30,0 \\
Cubatão & 20,0 \\
Mogi & 10,0 \\
Quilombo & 10,0 \\
Jurubatuba & 1,0 \\
Sandi & 0,5 \\
Diana & 0,5 \\
Santana-Boturuca & 1,5 \\
Mariana & 0,5 \\
Piaçabucu & 1,0 \\
Piaçaguera & 0,5 \\
Maratanua & 0,5 \\
Caipira & 0,5 \\
Aguari & 0,5
\end{tabular}
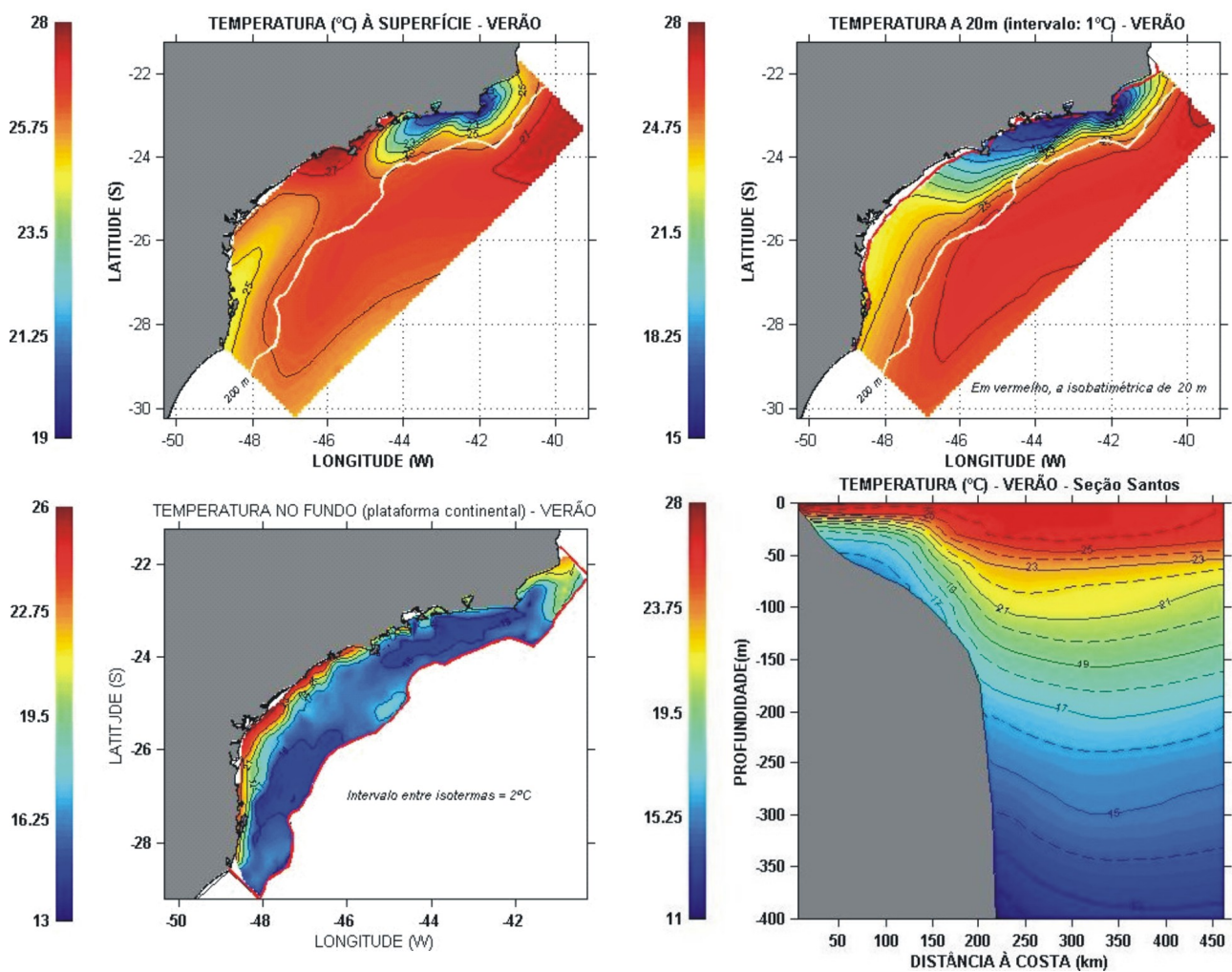

Figura 2.5: Distribuições horizontais em superfície, $20 \mathrm{~m}$ e no fundo para a temperatura $\left({ }^{\circ} \mathrm{C}\right)$ na Plataforma Continental Sudeste. O painel inferior direito é a seção vertical na radial de Santos. Adaptado de Rezende (2003)

De acordo com Rezende (2003), observa-se que na região da BS a temperatura superficial é de aproximadamente $28{ }^{\circ} \mathrm{C}$ (Figura 2.5. painéis superior esquerdo e inferior direito). Nas proximidades do fundo, a temperatura varia de $18{ }^{\circ} \mathrm{C}$ para a porção próxima à $30 \mathrm{~m}$ de profundidade à $24{ }^{\circ} \mathrm{C}$ nas isolinhas de $10 \mathrm{~m}$ (Figura 2.5. 

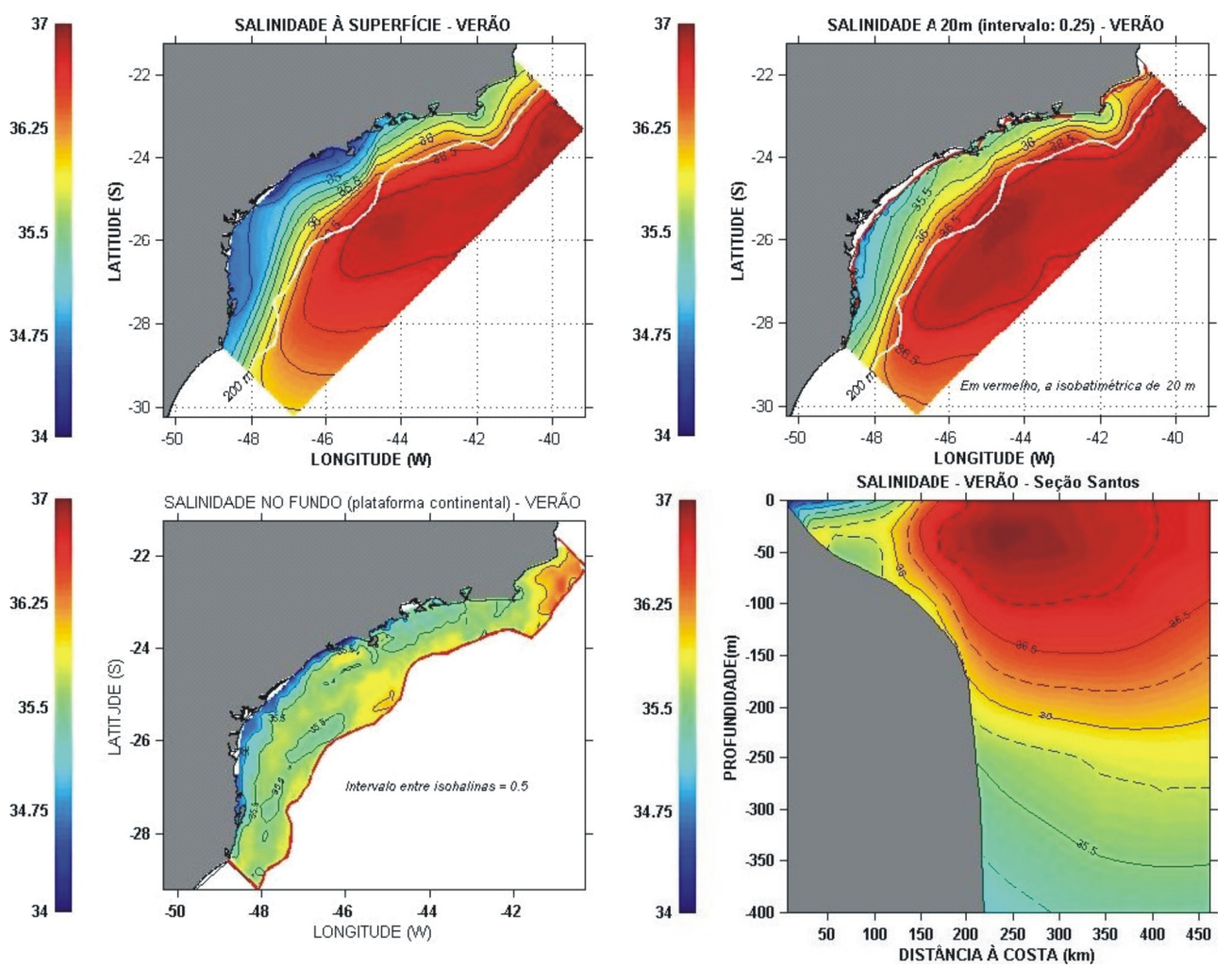

Figura 2.6: Distribuições horizontais em superfície, $20 \mathrm{~m}$ e no fundo para a salinidade na Plataforma Continental Sudeste. O painel inferior direito é a seção vertical na radial de Santos. Adaptado de Rezende (2003)

painéis inferiores esquerdo e direito).

Para a salinidade, a climatologia de Rezende (2003) aponta salinidades de 34 na camada superficial na região da BS (Figura 2.6 painéis superior esquerdo e inferior direito) e próximas a 35 em camadas inferiores (Figura 2.6, painéis inferiores esquerdo e direito).

Na porção estuarina, principalmente na BS e no CB, o projeto ECOSAN realizou campanhas mensais ao longo dos anos de 2005 e 2006. Na Figura 2.7 estão representados os pontos de coleta destes dados. Nestes pontos, foram realizadas medições de temperatura e salinidade, da superfície ao fundo. Nas Figuras 2.8 e 2.9 estão representadas as distribuições horizontais de temperatura e salinidade, respectivamente, para a camada superficial (esquerda), meia água (centro) e fundo (direita) nos meses de janeiro (painéis superiores), fevereiro (painéis do centro) e março (painéis inferiores). A temperatura nos meses de verão em superfície, na região estuarina, apresenta valores médios próximos a $25^{\circ} \mathrm{C}$, enquanto no fundo o valor é de $24^{\circ} \mathrm{C}$ (Figura 2.8). Para a salinidade, os valores médios encontrados para superfície e fundo foram de 23 e 34, respectivamente (Figura 2.9.

À partir da climatologia de Rezende (2003) para a plataforma continental, e dos dados do ECOSAN para a parte estuarina, foi possível estabelecer as condições 


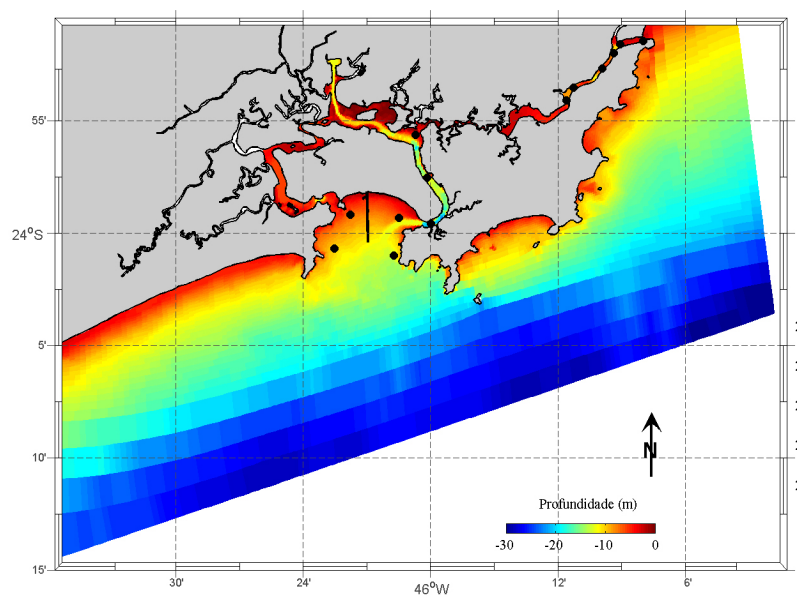

Figura 2.7: Os pontos pretos na figura representam locais de coleta de dados de temperatura e salinidade na Baía de Santos e canais estuarinos adjacentes, ao longo do ano de 2006 do projeto ECOSAN.
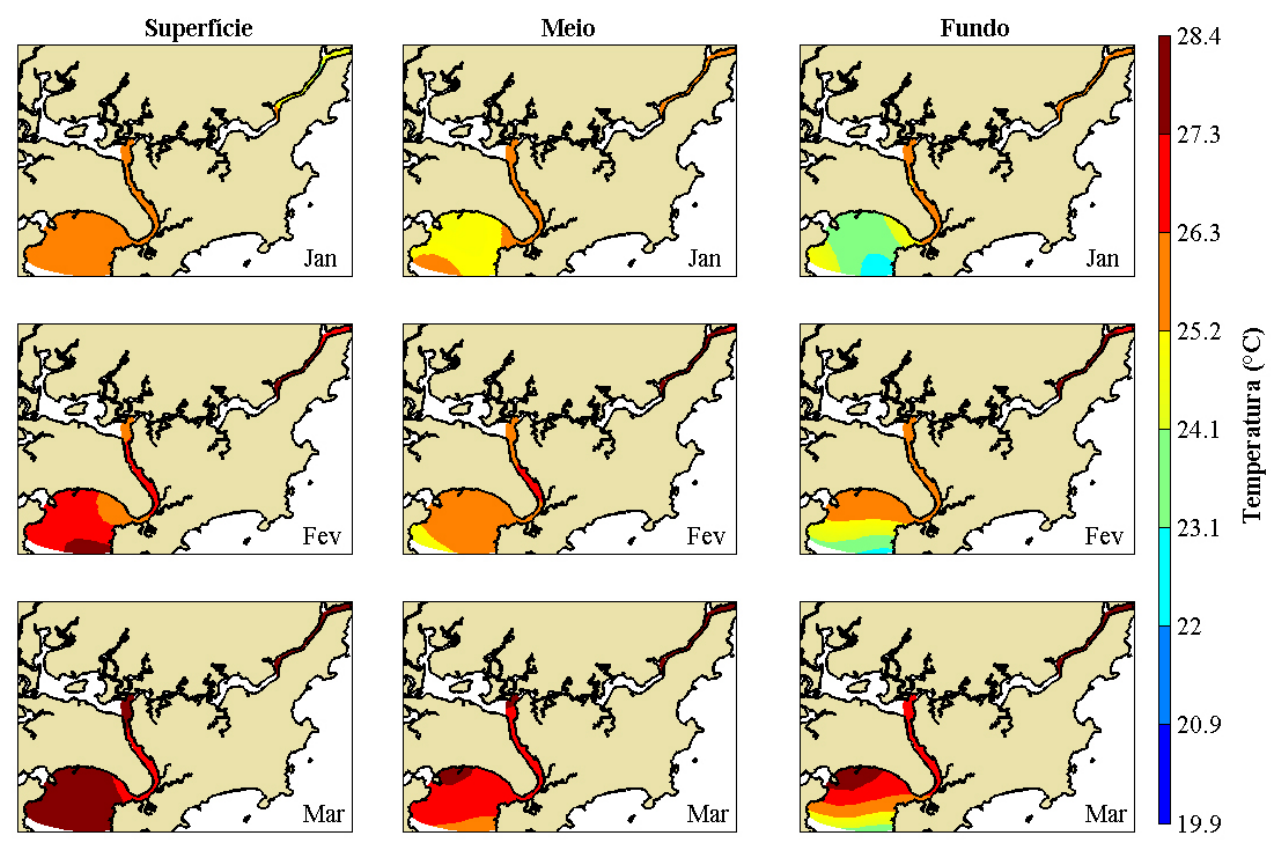

Figura 2.8: Distribuições horizontais de temperatura $\left({ }^{\circ} \mathrm{C}\right)$ para os meses de verão, obtidos no projeto ECOSAN, no ano de 2006, para o estuário santista.

iniciais e de contorno. As condições inicias definidas de temperatura e salinidade podem ser observadas nas Figuras 2.10 2.11, respectivamente. Tais figuras ilustram a distribuição horizontal das propriedades em superfície, 5m, 10m e na camada de fundo.

À partir das condições iniciais foi possível estabelecer também as condições de borda para as propriedades temperatura e salinidade. Nas Figuras 2.12 e 2.13 estão representadas estas condições impostas de modo a conservar os campos termohalinos prescritos inicialmente. 

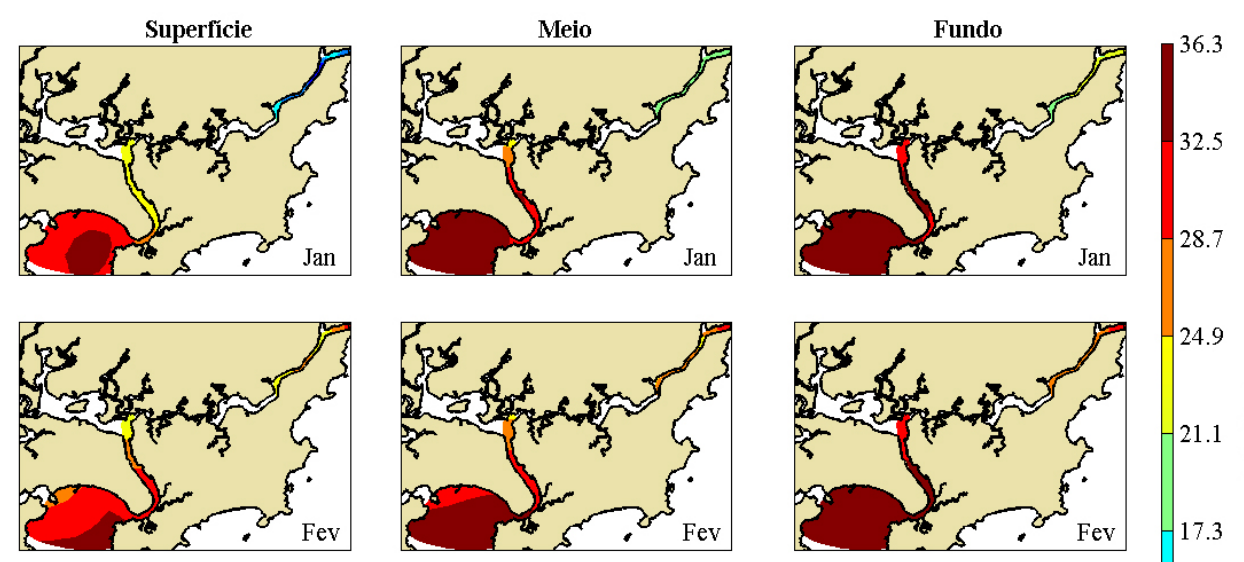

24.9
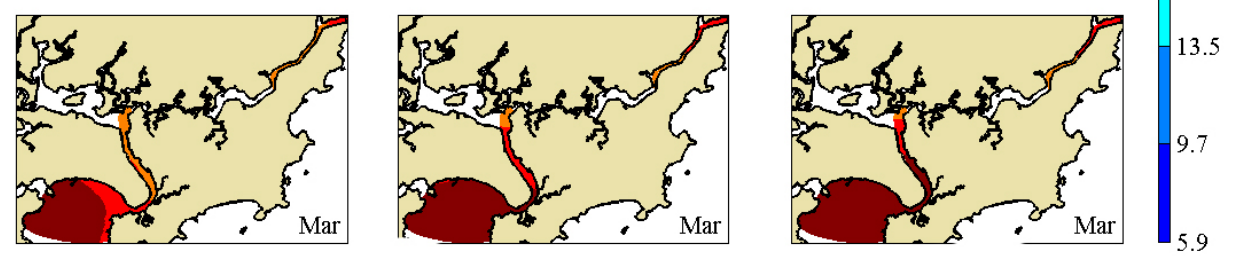

Figura 2.9: Distribuições horizontais de salinidade para os meses de verão, obtidos no projeto ECOSAN, no ano de 2006, para o estuário santista.
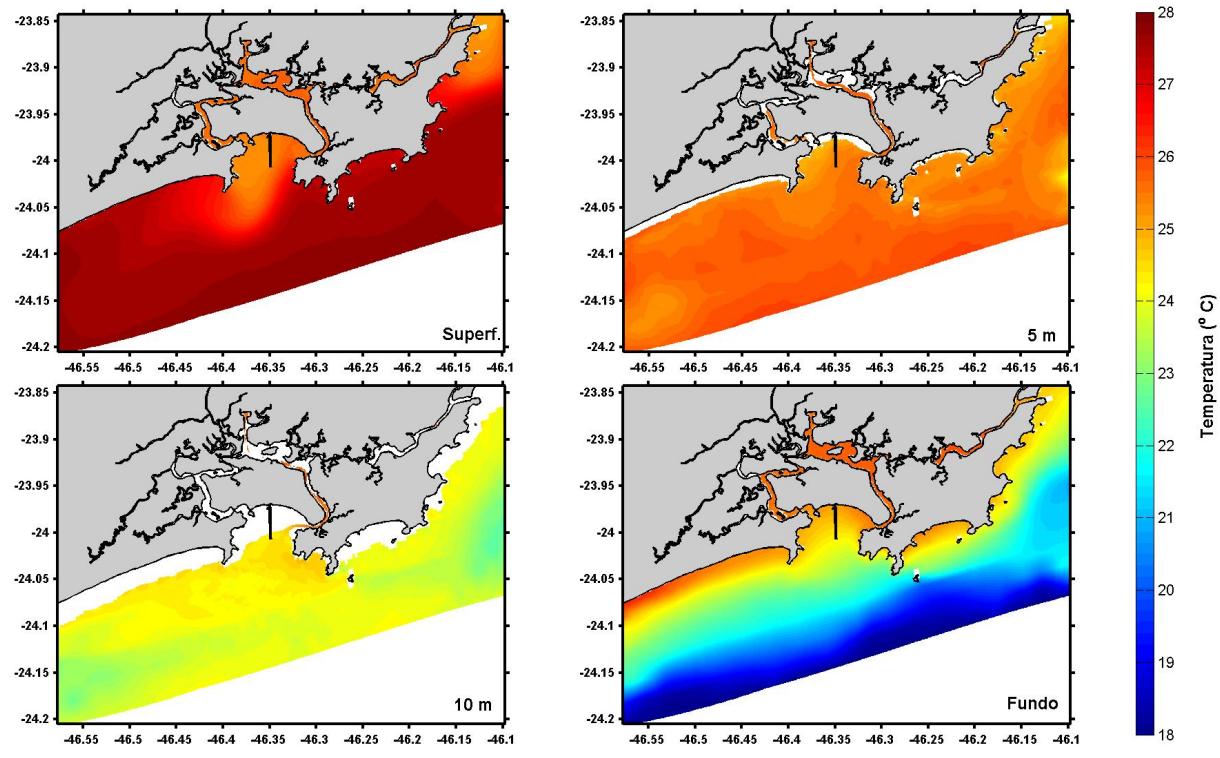

Figura 2.10: Distribuição horizontal da temperatura $\left({ }^{\circ} \mathrm{C}\right)$, representando a condição inicial para as simulações hidrodinâmicas. A profundidade referente está descrita no canto inferior direito de cada painel.

A temperatura e a salinidade dos estuários foram fixadas em $25^{\circ} \mathrm{C}$ e 23 , respectivamente. Estes valores apresentam-se constantes ao longo da coluna de água.

Os ventos médios na região foram obtidos pela estação meteorológica instalada pelo ECOSAN na Laje de Santos, nas coordenadas $24^{\circ} 19.2^{\prime} \mathrm{S}$ e $46^{\circ} 10.8^{\prime} \mathrm{W}$. Os dados utilizados são referentes aos meses de janeiro a março dos anos de 2006 e 2007. Todos os dados, coletados com espaçamento horário, foram plotados na forma de rosa 

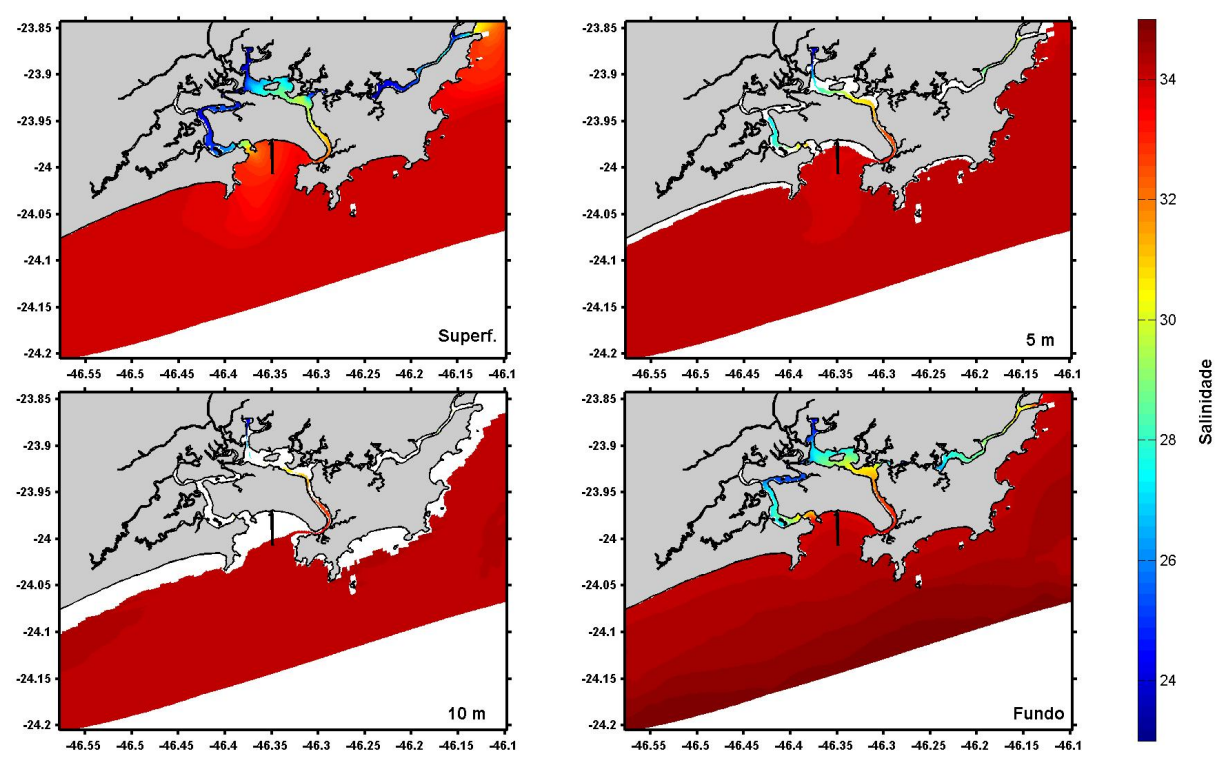

Figura 2.11: Distribuição horizontal da salinidade, representando a condição inicial para as simulações hidrodinâmicas. A profundidade referente está descrita no canto inferior direito de cada painel.
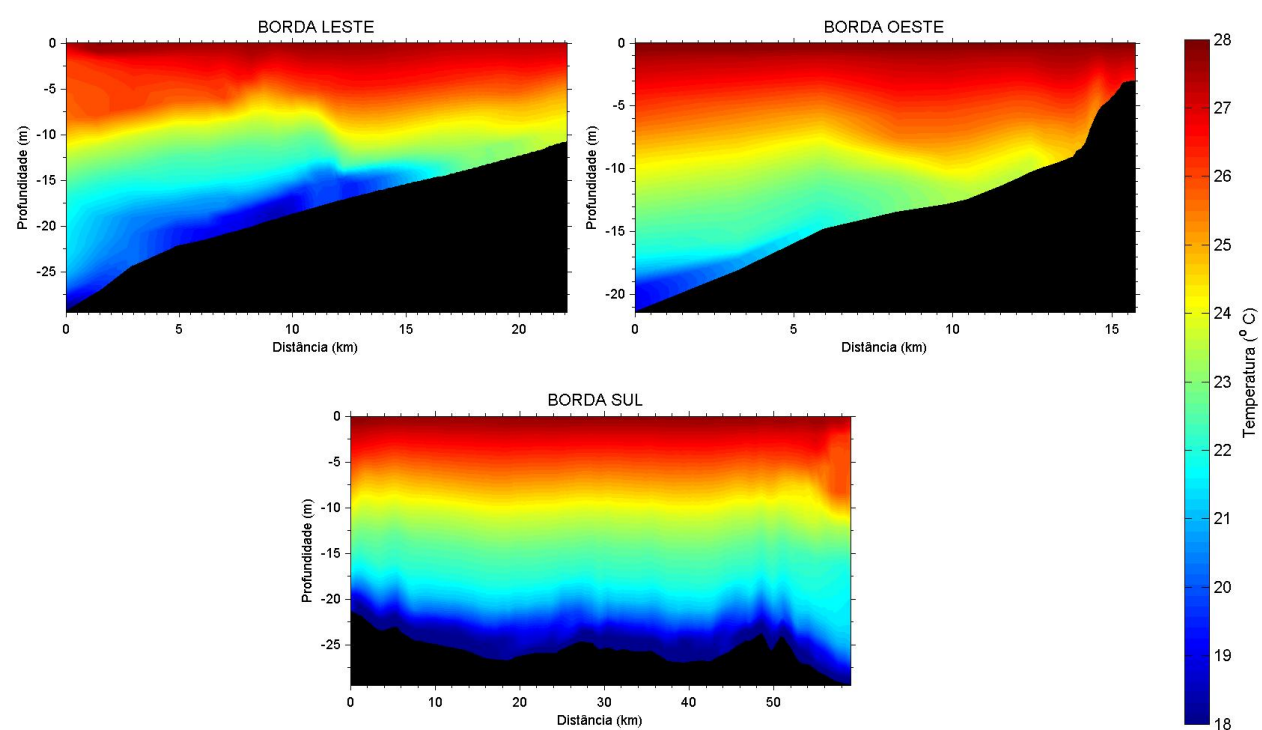

Figura 2.12: Seção vertical de temperatura $\left({ }^{\circ} \mathrm{C}\right)$, representando a condição de borda para as simulações hidrodinâmicas. A borda referente esta descrita no título de cada painel.

de distribuição, ressaltando-se a frequência de ocorrência, exibidos na Figura 2.14. Essa Figura mostra que o vento que ocorre com maior frequência na região possui magnitude da ordem de 1,2 m.s ${ }^{-1}$, com direção de aproximadamente $30^{\circ}$ (convenção meteorológica para a direção do vento).

Além do vento médio, construímos também uma climatologia para a passagens de sistemas frontais na região. Os sistemas frontais que percorrem o litoral leste da 


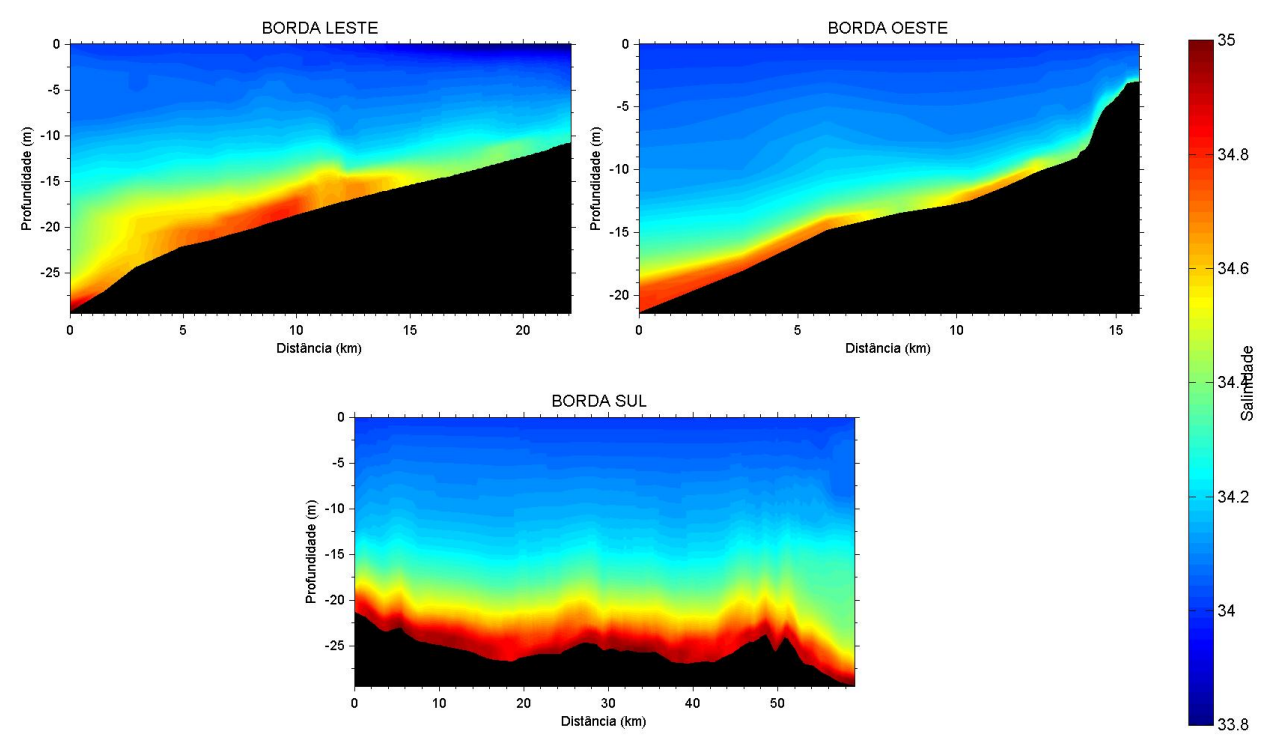

Figura 2.13: Seção vertical de salinidade, representando a condição de borda para as simulações hidrodinâmicas. A borda referente esta descrita no título de cada painel.

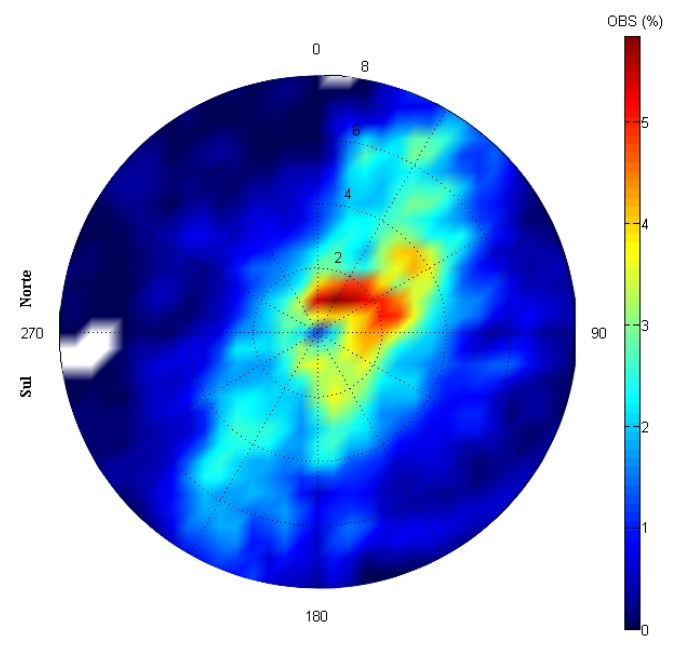

Figura 2.14: Frequência de ocorrência de ventos no verão 2006 e 2007 para a laje de Santos.

América do Sul deslocam-se, tipicamente, na direção sudoeste-nordeste (Rodrigues et al. 2004). Usamos 25 anos de dados do programa NCEP/DOE Reanalysis 2 (Kanamitsua et al. 2002), englobando os anos de 1983 a 2007. Neste intervalo temporal, foi utilizada a magnitude e a direção do vento a $10 \mathrm{~m}$ da superfície do mar, bem como a temperatura no nível barométrico de $1000 \mathrm{hPa}$, para os meses de janeiro, fevereiro e março, interpolandos para o centro da BS $\left(24^{\circ} \mathrm{S}, 46^{\circ} 19.80^{\prime} \mathrm{W}\right)$. Os dados deste banco são disponibilizados 4 vezes ao dia, espaçados regularmente a cada 6 horas. 
A identificação dos períodos de passagem de sistemas frontais foi realizada de acordo com o método descrito por Rodrigues et al. (2004). Neste trabalho, em que foram quantificadas as passagens de sistemas frontais pelo litoral de Santa Catarina, para se determinar a passagem destas, foi considerada a verificação dos seguintes critérios, em sequência:

- giro do vento do quadrante norte para quadrante sul, o que representa uma inversão no sinal do vento meridional de negativo para positivo;

- permanência do vento sul por pelo menos um dia;

- queda de temperatura do ar no momento do giro do vento, ou até dois dias depois, de pelo menos $0,5^{\circ} \mathrm{C}$.

Para eliminar as variações diárias, associadas principalmente à brisas marinhas, os dados passaram por aplicação de filtro passa baixa, com frequência de corte de 30 h, de acordo com Walters \& Heston (1982). Assim, foi possível obter o número médio de passagem de sistemas frontais durante o verão, a duração média e o intervalo médio entre a passagem destes sistemas frontais. Além disso, características da variação da magnitude e direção dos ventos em períodos de passagens de sistemas frontais forma definidas.

\subsection{Modelagem do campo próximo}

Alguns dos principais modelos matemáticos numéricos nos dias atuais para o campo próximo são: UM3, RSB (NRFIELD) e CORMIX. Segundo resultados obtidos por Carvalho et al. (2002) e Roberts \& Tian (2004), UM3 e RSB apresentaram resultados melhores do que o CORMIX, para diluição, quando comparados a observações de campo.

Neste estudo será utilizado o primeiro modelo, UM3, que é um modelo lagrangeano e tridimensional. As equações de conservação de massa, momentum e energia são resolvidas em espaços de tempo, fornecendo a diluição ao longo da trajetória do jato. Para determinar o desenvolvimento de cada elemento, UM3 utiliza a hipótese do entranhamento de Taylor e a hipótese da área projetada por entranhamento (Frick 1984). Os fluxos começam com jatos flutuantes circulares emitidos pelo difusor, podendo haver fusão de dois ou mais jatos. A saída do modelo consiste em características do jato ao longo de sua trajetória, tal como a diluição da linha central, a largura, e a altura da linha central. A descrição matemática dos processos envolvidos é apresentada no Apêndice B.

O efluente foi tratado de forma conservativa, não apresentando taxas de decaimento, tendo sua diluição provocada pelos processos dispersivos aplicado pelo 
modelo numérico UM3. Ainda, foi considerada concentração inicial de 0 partes por milhão (ppm) no ambiente, sendo a única fonte de contaminante o ESS.

\subsection{Interface entre os modelos de campo próximo e distante}

A Figura 2.15 indica quatro possíveis acoplamentos de massa (M) e fluxo, devidos às descarga dos efluentes $\left(\mathrm{Q}_{0}\right)$, no modelo de campo distante.
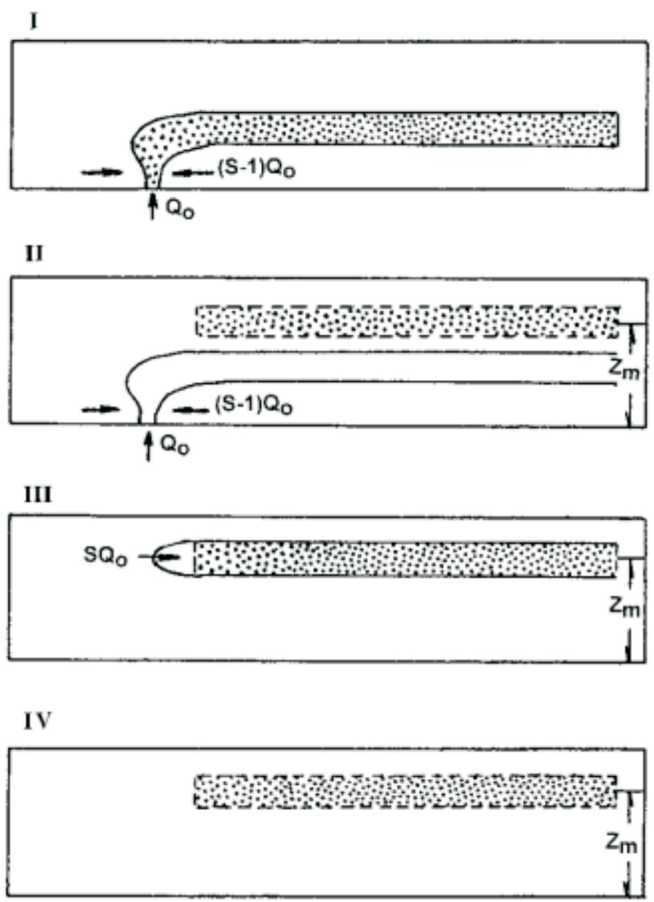

Figura 2.15: Possíveis acoplamentos de massa(M) e fluxo, gerado pela descarga dos efluentes $\left(\mathrm{Q}_{0}\right)$ no modelo de campo distante (Zhang \& Adams (1999))

Método I: Simulação de fluxos e descargas através de controle da mistura inicial

No primeiro painel da Figura 2.15, a carga poluente M é introduzida junto com a água doce $Q_{0}$. Assim, efeitos dinâmicos associado ao empuxo do efluente e seu momento estão incluídos implicitamente. Como é sabido que modelos de campo distante não prevêem exatamente o nível de estabilização do jato no campo próximo, podemos ajustar localmente ou globalmente os coeficientes de mistura ou, ainda, o tamanho da grade numérica e os parâmetros do efluente. Zhang \& Adams (1999), sugerem que o mais prático é variar os parâmetros locais de difusão horizontal e vertical. A vantagem de introdução das cargas na fonte é que toda a pluma é simulada em conjunto com a dinâmica do efeito da água doce 
sobre o ambiente. Desta forma, o decaimento e os processos que envolvem o transporte de poluentes podem ser tratados corretamente.

Método II: Desacoplamento da simulação de fluxos e cargas

Com relação ao segundo painel da Figura 2.15, a carga do poluente (M) é introduzida na profundidade de estabilização do jato $\left(Z_{m}\right)$ prevista pelo modelo de campo próximo, enquanto que a água doce $\left(\mathrm{Q}_{0}\right)$ é introduzido na fonte local. A altura prevista pelo modelo de campo próximo pode ser diferente da altura prevista pelo modelo de campo distante, fazendo com que os poluentes sofram espalhamento gravitacional incorreto, conforme relatado por Zhang (1995).

Método III: Simulação de fluxos diluídos e cargas

No terceiro painel, o espalhamento gravitacional é introduzido pela quantidade de água doce diluída $\left(\mathrm{SQ}_{0}\right)$ na profundidade de estabilização do jato $\left(\mathrm{Z}_{m}\right)$ prevista pelo modelo de campo próximo juntamente com carga de efluente (M). A diluição correta $\mathrm{S}$ é prevista pelo modelo de campo próximo. Entretanto, como o entranhamento é ignorado, massa adicional é incluída no domínio e o real entranhamento ao longo da trajetória é ignorado. Essa opção pode ser descartada pois o modelo de campo distante não pode simular corretamente as interações que ocorrem no campo próximo.

Método IV: Simulação apenas das cargas

No último painel, a carga do poluente (M) é introduzida na profundidade de estabilização do jato $\left(Z_{m}\right)$ estimada pelo modelo de campo próximo e é imposta ao modelo de campo distante. Efetivamente, esta opção assume que os efeitos dinâmicos são negligenciados no domínio computacional. Segundo Zhang \& Adams (1999), em comparação ao primeiro método, este subestima a propagação lateral devido à omissão da circulação gravitacional. No entanto este fator é compensado, pois o espalhamento lateral é geralmente exagerado devido à difusão numérica provocada pela resolução da grade.

Ainda segundo os autores mencionados, os métodos I e IV são geralmente os preferíveis. O método I, com controle dinâmico, é fundamentalmente o mais preciso, mas tem dificuldade em prever a estratificação do ambiente em simulação de longo termo. O método IV é provavelmente suficiente para muitos problemas práticos e será o empregado nesta Dissertação de Mestrado. 
Outra dificuldade é implementar a concentração e a dimensão da pluma prevista pelo modelo de campo próximo na grade numérica implementada para o modelo de campo distante. O modelo de campo próximo prevê elementos esféricos e a grade computacional é retangular. A Figura 2.16 mostra as relações de área e volume entre o elemento esférico e a grade numérica.
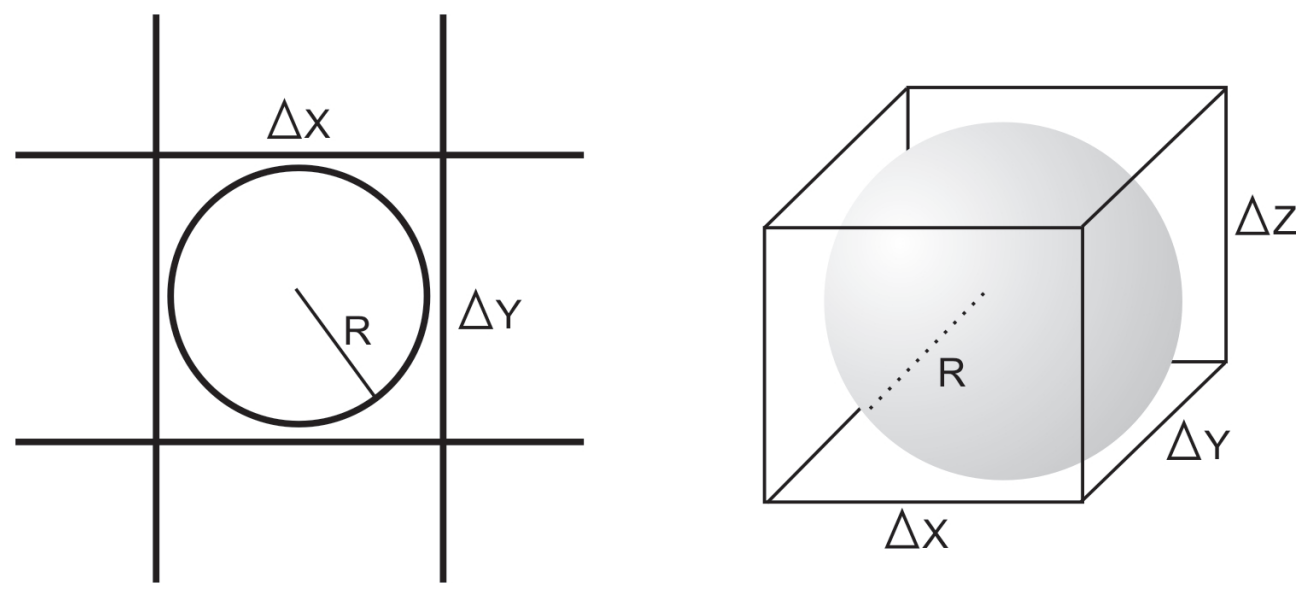

Figura 2.16: Relação entre a pluma prevista pelo modelo de campo próximo (esquerda) e a grade numérica imposta para o modelo de campo distante (direita).

Como serão usadas coordenadas verticais sigma (Seção 2) a porção $\Delta Z$ varia de acordo com a superfície livre, impossibilitando uma determinação exata do volume da célula em que será imposta a carga prevista pelo modelo de campo próximo. Desta forma, nesta Dissertação de Mestrado será utilizada a relação entre área do retângulo e área da circunferência para relacionar a concentração prevista pelo modelo de campo próximo e a concentração imposta no modelo de campo distante. Para tal, será utilizada razão inversa entre as áreas e as concentrações (quanto maior a área menor a concentração). A equação 2.10 mostra esta relação entre as concentrações prevista pelo modelo de campo próximo $(C C P)$ e a concentração imposta no modelo de campo distante $(C C D)$.

$$
C C D=\frac{\Delta X \cdot \Delta Y \cdot C C P}{\pi \cdot R^{2}}
$$

onde, $\Delta X$ e $\Delta Y$ são os comprimentos laterais da célula na grade numérica, de acordo com os eixos coordenados $x$ e $y$, e $R$ é o raio da pluma ao final do campo próximo.

\subsection{Modelagem do campo distante}

Para simular o campo distante, utilizamos o módulo de qualidade de água da suíte computacional desenvolvida pela WL | Delft Hydraulics, Holanda, denominado DELFT3D - WAQ, o qual resolve as equações de advecção-difusão incluindo termos de reações físicas, bioquímicas e de processos biológicos. Um número amplo 
de substâncias pode ser modelado, tais como nutrientes e matéria orgânica. Este módulo utiliza-se das condições hidrodinâmicas (velocidades, elevação da superfície livre, densidade, salinidade, temperatura, viscosidade e difusividade turbulentas) calculadas pelo módulo hidrodinâmico (DELFT3D-FLOW). As condições iniciais de concentração do campo distante serão fornecidas a partir de resultados provenientes do modelo de campo próximo, conforme descrito anteriormente na Seção 2.3. Como na modelagem do campo próximo, o efluente foi tratado de forma conservativa, tendo sua diluição provocada exclusivamente pela advecção e difusão (dispersão). Ainda, foi considerada concentração inicial de 0 partes por milhão (ppm) no ambiente, sendo a única fonte de contaminante o ESS.

O balanço de massa no sistema é garantido pela equação de conservação de massa (Equação 2.4). A equação espaço-temporal para o transporte de substâncias envolve sua variação local e advectiva, associada à difusão e processos de decaimento. A equação 2.11 engloba estas parcelas.

$$
\frac{\partial c}{\partial t}+u \frac{\partial c}{\partial x}+v \frac{\partial c}{\partial y}+w \frac{\partial c}{\partial z}=\frac{\partial}{\partial x}\left(K_{h} \frac{\partial c}{\partial x}\right)+\frac{\partial}{\partial y}\left(K_{h} \frac{\partial c}{\partial y}\right)+\frac{\partial}{\partial z}\left(K_{v} \frac{\partial c}{\partial z}\right)-K_{d} c+f_{R}
$$

onde $c$ é a concentração da substância, $K_{h}$ e $K_{v}$ são os coeficientes de difusão turbulenta horizontal e vertical, $K_{d}$ é o coeficiente de decaimento e $f_{R}$ são demais reações. Tais reações ou processos listados em $f_{R}$ podem ser processos físicos ou de outra natureza. Exemplos de processos físicos podem ser:

- movimentos da água que não afetam substâncias, como evaporação;

- volatilização de substâncias próximas à superfície;

- processos que envolvam materiais particulados, entre outros.

Dentre processos de outra natureza podemos citar:

- conversões bioquímicas, como amônia e oxigênio formando nitrato;

- produção primária;

- predação;

- reações químicas diversas, entre outros.

As equações que descrevem tais processos para uma ampla gama de substâncias podem ser obtidas em Delft3DWAQ (2006). 


\subsection{Projetos para o emissário submarino de Santos}

A modelagem da dispersão da pluma do emissário de Santos foi realizada de acordo com três características de projetos: o projeto original de construção, datado de 1979; o projeto novo, que entra em operação no ano de 2009, e uma proposta de projeto feita por esta Dissertação de Mestrado. Na Tabela 2.4 são identificados os projetos utilizados nesta dissertação, com suas principais características.

De acordo com a Tabela 2.4 o projeto proposto por esta Dissertação de Mestrado possui extensão de $8.000 \mathrm{~m}$ (duas vezes a extensão original), mantendo tanto as características dos difusores (quantidade, diâmetro e espaçamento) impostas para o novo projeto, quanto do efluente (vazão e densidade). A Figura 2.17 apresenta a localização dos projetos de emissário na BS para esta Dissertação de Mestrado.

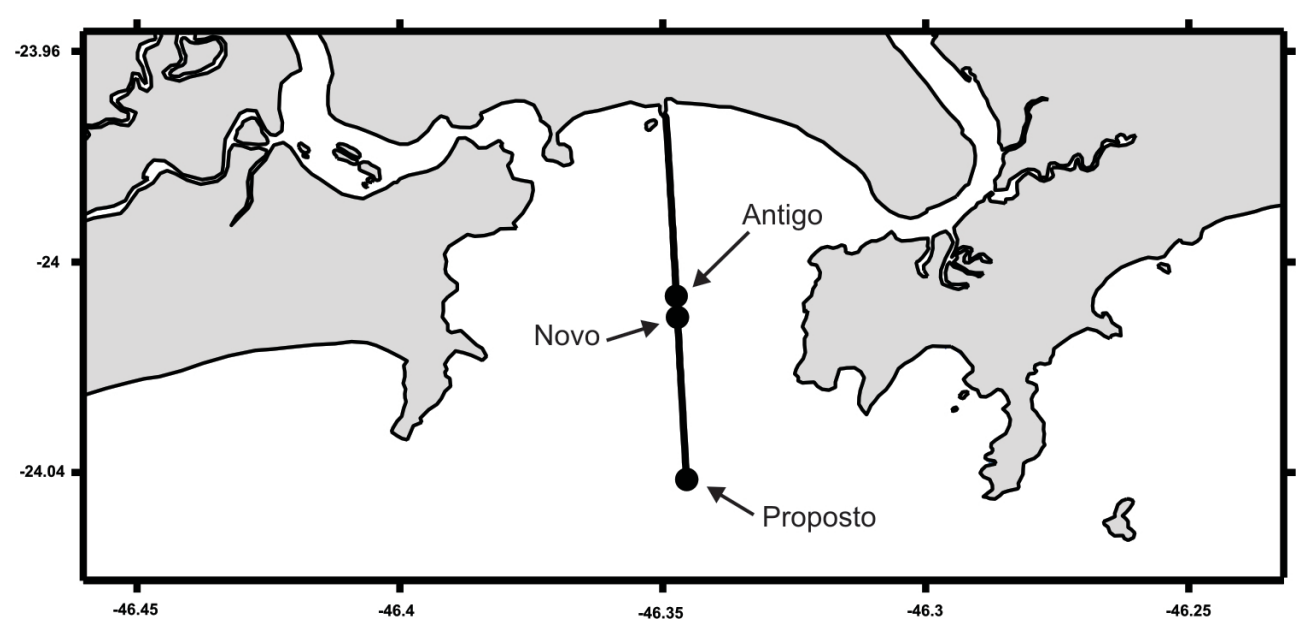

Figura 2.17: Localização dos projetos do ESS utilizados nas simulações numéricas.

Tabela 2.4: Projetos do emissário submarino de Santos para as simulações de campo próximo e distante.

\begin{tabular}{|c|c|c|c|c|c|c|}
\hline Projeto & \multirow{2}{*}{ Extensão } & \multicolumn{3}{|c|}{ Difusores } & \multicolumn{2}{c|}{ Efluente } \\
\cline { 3 - 7 } & & Qdade. & Diâmetro & Distância & Vazão & Densidade \\
\hline \hline Antigo & $4.007 \mathrm{~m}$ & 40 & $0,2 \mathrm{~m}$ & $5,3 \mathrm{~m}$ & $3,0 \mathrm{~m}^{3} \cdot \mathrm{s}^{-1}$ & $998 \mathrm{~kg} \cdot \mathrm{m}^{-3}$ \\
\hline Novo & $4.407 \mathrm{~m}$ & 119 & $0,2 \mathrm{~m}$ & $5,3 \mathrm{~m}$ & $5,3 \mathrm{~m}^{3} \cdot \mathrm{s}^{-1}$ & $998 \mathrm{~kg} \cdot \mathrm{m}^{-3}$ \\
\hline Proposto & $8.000 \mathrm{~m}$ & 119 & $0,2 \mathrm{~m}$ & $5,3 \mathrm{~m}$ & $5,3 \mathrm{~m}^{3} \cdot \mathrm{s}^{-1}$ & $998 \mathrm{~kg} \cdot \mathrm{m}^{-3}$ \\
\hline
\end{tabular}

\subsection{Cenários propostos}

Nesta seção serão apresentados os cenários hidrodinâmicos e de campos próximo e distantes propostos para o estudo da dispersão da pluma de efluentes do ESS.

Em todos os cenários, o tempo total de simulação é de 19 dias. Simbolicamente, as datas limites impostas foram 01/02/2007 a 19/02/2007. Durante este período, 
foi observada uma maré de sizígia, seguida por uma de quadratura, finalizando em outra de sizígia. Em todos os cenários, os campos iniciais de temperatura, salinidade e concentração dos efluentes, bem como as condições de bordas, estão de acordo com o apresentado nas Seções 2.1, 2.2 e 2.4 .

O primeiro cenário simulado apresenta como forçantes a maré astronômica nas bordas abertas oceânicas (sul, leste e oeste, Figura 2.1 e Tabela 2.2 e a vazão dos principais rios na região estuarina (Figura 2.4 e Tabela 2.3.

O segundo cenário proposto, além das forçantes maré e vazão descritas para o primeiro cenário, também inclui o vento médio como forçante (Seção 2.6). Este vendo é aplicado de forma constante e homogênea.

O terceiro cenário proposto simula a entrada de sistemas frontais na região. Simulamos a presença do vento médio, conforme descrito para o segundo cenário e, em situações de maré de quadratura e sizígia, aplicamos a mudança do vento, de acordo com a climatologia obtida pelos métodos descritos na Seção 2.1 e que será apresentada na Seção 3.1. Os cenários de quadratura e sizígia ocorrem independentemente um do outro, sendo que em ambos os casos o vento antecedente ao evento de entrada de sistema frontal é o vento médio (segundo cenário). Resumidamente, na Tabela 2.5 estão apresentados os cenários ambientais propostos.

Tabela 2.5: Cenários ambientais propostos para as simulações

\begin{tabular}{|c|c|c|}
\hline cenário & Forçantes Oceânicas & Forçantes Atmosféricas \\
\hline \hline C1 & $\begin{array}{c}\text { Maré astronômica } \\
\text { vazão dos rios estuarinos }\end{array}$ & Ausente \\
\hline C2 & $\begin{array}{c}\text { Maré astronômica } \\
\text { vazão dos rios estuarinos }\end{array}$ & Vento médio \\
\hline C3 & $\begin{array}{c}\text { Maré astronômica } \\
\text { vazão dos rios estuarinos }\end{array}$ & $\begin{array}{c}\text { Vento médio com } \\
\text { passagem de sistema frontal }\end{array}$ \\
\hline
\end{tabular}

Para cada um dos cenários ambientais (C1, C2 e C3), foi simulada a dispersão do efluente para os três projetos de emissário da Tabela 2.4. totalizando nove experimentos numéricos. 


\section{Capítulo 3}

\section{Resultados}

Nesta seção serão apresentados os resultados obtidos nesta Dissertação de Mestrado. Conforme descrito esquematicamente na Figura 1.4 para o estudo da diluição total da pluma do ESS é necessária a modelagem do campo próximo e, por fim, a modelagem do campo distante. Em todas estas etapas de modelagem, os resultados serão descritos para cada um dos cenários propostos na Seção 2.6 .

Inicialmente serão apresentados os resultados da determinação do sistema frontal climatológico. Em sequência, serão apresentados os resultados hidrodinâmicos, campo próximo e campo distante. Estes serão mostrados em períodos de pico de quadratura (menores amplitudes de maré) e pico de sizígia (maiores amplitudes de maré). Tal determinação contempla os extremos de circulação, pois os períodos intermediários apresentam características intermediárias entre os resultados apresentados. Para exemplificar este fato, é mostrado na Figura 3.1 um ciclo de maré de quadratura e um de sizígia (segmentos em vermelho), obtido por este estudo na posição $23,95^{\circ} \mathrm{S}, 46^{\circ} \mathrm{O}$ para o cenário 1 entre os dias 10/02/2007 e 17/02/2007.

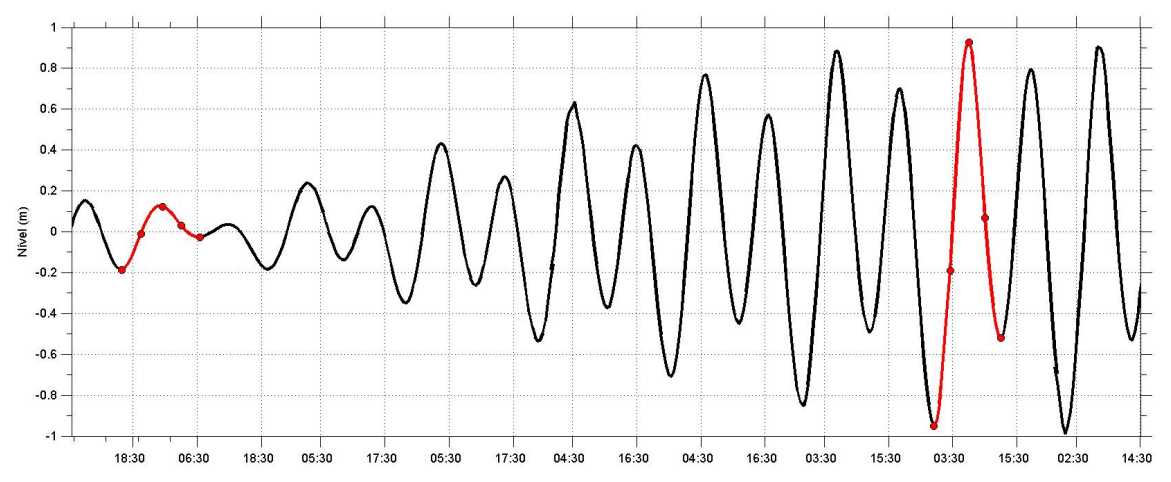

Figura 3.1: Nível do mar exemplificando ciclos de enchente-vazante em período de marés de quadratura (segmento em vermelho à esquerda) e de marés de sizígia (segmento em vermelho à direita), obtido por este estudo na posição $23,95^{\circ} \mathrm{S}, 46^{\circ} \mathrm{O}$ para o cenário 1 .

Na Figura 3.1, é observado no segmento em vermelho à esquerda um ciclo de 
enchente (nível aumentando) e vazante (nível diminuindo) de maré de quadratura. O mesmo é observado no segmento em vermelho à direita, porém com amplitudes relativamente maiores, típicas de maré de sizígia. As circunferências marcadas sobre os segmentos em vermelho indicam pontos de interesse ao longo de um ciclo de enchente-vazante de maré. Seguindo a ordem cronológica, a primeira circunferência indica o início do ciclo, com o menor nível observado. A segunda circunferência indica um instante de enchente. A terceira indica o instante em que o sistema obtém seu nível máximo local. A quarta circunferência indica um instante de vazante, e por fim, a última circunferência indica o fim do ciclo enchente-vazante.

Seguindo a ordem cronológica descrita por tais circunferências, os resultados serão embasados nestes instantes de tempo. Os resultados referentes ao nível do sistema serão apresentados nestes 5 instantes descritos, para ambos períodos de maré (quadratura e sizígia). Para os resultados referentes à velocidade, densidade e dispersão da pluma de efluentes no campo próximo, serão apresentados apenas os instantes de extremos, ou seja, baixamares (instante de nível mínimo) e preamares (instantes de nível máximo) de sizígia e quadratura (Tabela 2.5). Para o resultado da dispersão da pluma no campo distante, todo o ciclo de enchente-vazante de maré será contemplado.

\subsection{Sistema frontal climatológico}

Na Tabela 3.1 são apresentados os valores obtidos para o número médio de sistemas frontais, a duração média dos ventos provenientes do quadrante sul devido à passagem dos sistemas frontais e o intervalo médio entre a passagem de sistemas frontais durante o verão na BS obtidos neste estudo.

Tabela 3.1: Características médias dos sistemas frontais durante os três meses de verão para a Baía de Santos.

\begin{tabular}{|c|c|}
\hline Número de eventos & $10,3 \pm 1,7$ \\
\hline Intervalo & $135,7 \pm 122,0 \mathrm{~h}$ \\
\hline Duração & $76,1 \pm 45,4 \mathrm{~h}$ \\
\hline
\end{tabular}

Os dados mostram que os sistemas frontais passam na região com intervalo médio de 5,5 dias, fazendo com que os ventos provenientes do quadrante sul durem 3,1 dias. Foram obtidos também intensidades e direções médias no dia anterior à entrada de frente (dia -1), no dia da entrada de frente (dia 0), e nos outros 3 dias em que ocorre a passagem da frente. Essa variação média pode ser observada na Tabela 3.2 e sua representação gráfica por meio de "stickplot"na Figura 3.2 .

Observa-se que ocorre uma intensificação dos ventos de origem nordeste no dia anterior (-1) ao da passagem do sistema frontal. Após, o vento gira, sendo prove- 
Tabela 3.2: Direção (D - - convenção meteorológica) e intensidade (I - m.s $\left.{ }^{-1}\right)$ médios para 1 dia anterior a entrada de sistema frontal $(-1)$, no dia de entrada de sistema frontal $(0)$ e próximos 3 dias subsequentes $(+1,+2$ e +3$)$ para a Baía de Santos.

\begin{tabular}{|c|c|c|c|c|c|c|c|c|c|c|}
\hline Hora & \multicolumn{2}{|c|}{$[-1]$} & \multicolumn{2}{|c|}{$[0]$} & \multicolumn{2}{c|}{$[+1]$} & \multicolumn{2}{c|}{$[+2]$} & \multicolumn{2}{c|}{$[+3]$} \\
\hline & $\mathrm{D}$ & $\mathrm{I}$ & $\mathrm{D}$ & $\mathrm{I}$ & $\mathrm{D}$ & $\mathrm{I}$ & $\mathrm{D}$ & $\mathrm{I}$ & $\mathrm{D}$ & $\mathrm{I}$ \\
\hline $0: 00$ & 31,8 & 3,7 & 123,2 & 2,5 & 151,3 & 5,3 & 137,6 & 3,9 & 112,8 & 2,8 \\
\hline $6: 00$ & 33,7 & 3,4 & 151,5 & 4,1 & 146,2 & 4,8 & 130,1 & 3,6 & 106,6 & 2,7 \\
\hline $12: 00$ & 57,8 & 2,2 & 154,3 & 5,2 & 144,2 & 4,2 & 120,4 & 3,2 & 102,4 & 2,7 \\
\hline $18: 00$ & 124,0 & 2,4 & 151,8 & 5,2 & 138,1 & 3,9 & 113,7 & 2,7 & 98,2 & 2,7 \\
\hline
\end{tabular}

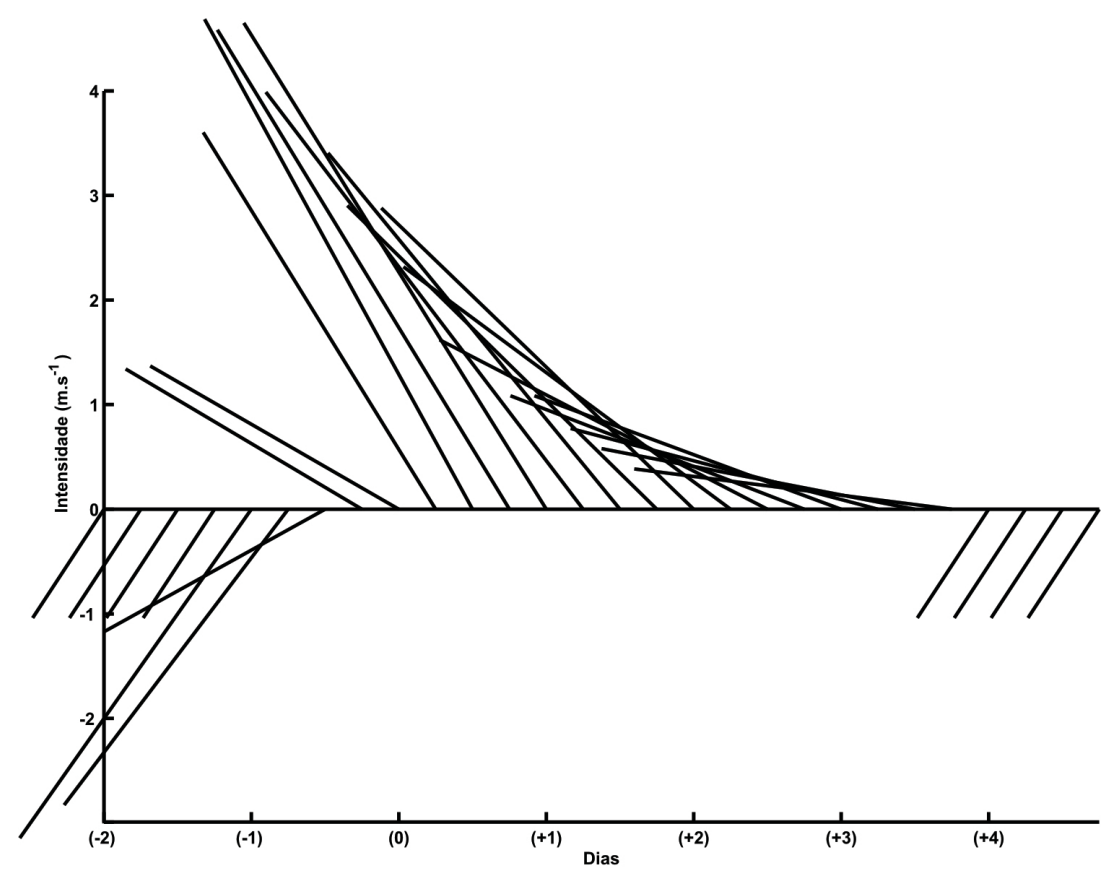

Figura 3.2: Representação vetorial climatológica da passagem de sistema frontal na Baía de Santos. O dia 0 representa o dia da entrada do sistema frontal. O Norte aponta para cima.

niente de sudeste, permanecendo por dois dias $(0)$ e $(+1)$. Na sequência, no dia +2 , o vento ganha direção leste, retornando à direção nordeste no decorrer do dia +3 .

Esta climatologia descrita será utilizada como o vento característico de sistema frontal empregado no cenário 3, conforme descrito na Seção 2.6.

\subsection{Modelagem hidrodinâmica}

A primeira parte de apresentação dos resultados de hidrodinâmica será referente ao nível. Em sequência, serão apresentados os resultados de velocidade e, por fim, os resultados de densidade. 


\subsubsection{Nivel}

Nas Figuras 3.3 e 3.4 são apresentados os resultados de nível para o cenário 1, durante um ciclo de enchente-vazante de marés de quadratura e sizígia, respectivamente. Durante o ciclo de maré de quadratura (Figura 3.3), no instante a) foram modelados em todo o sistema níveis abaixo de $0,00 \mathrm{~m}$, caracterizando situação de baixa-mar. Neste instante, a região que apresenta o nível mais elevado $(-0,17 \mathrm{~m})$ é o CSV, em oposição à região central do CB, que apresenta o menor nível (-0,20 m). No instante b), que caracteriza um momento de enchente de maré, foi modelado o nível mais baixo na região ao largo $(-0,05 \mathrm{~m})$, enquanto a região com nível mais elevado é o AES (-0,02 m). Importante ressaltar que o CSV e o CP apresentam similaridade entre seus níveis, sugerindo propagação simultânea da onda de maré por estes canais. Situação similar à encontrada em b) foi modelada no instante c), porém com valores maiores, caracterizando o instante de preamar. No instante seguinte, d), as relações entre os níveis dos CSV, CP e CB mantêm-se as mesmas do instante anterior, porém com valores reduzidos, caracterizado um momento de vazante. Novamente observa-se a similaridade entre os níveis do CSV e CP, confirmando a propagação simultânea da onda de maré por estes canais. Finalmente, no instante e) são modelados padrões semelhantes ao instante a), caracterizando um instante de baixamar.


Cenário 1 (Quadratura)

Figura 3.3: Variação do nível $(\mathrm{m})$ ao longo de um ciclo de enchente-vazante em maré de quadratura, para o cenário 1. Cada painel indica um instante de tempo, identificado pelo índice no canto superior esquerdo e a curva de nível em destaque.

Durante o ciclo de maré de sizígia (Figura 3.4), observaram-se similaridades com o ciclo de maré de quadratura (Figura 3.3). As mesmas evidências e locais de 
níveis máximos e mínimos são encontrados em todos os instantes, a) a e), porém, como característica de período de sizígia, as amplitudes são maiores. No instante de baixamar a), o mínimo modelado é de aproximadamente $-1,00 \mathrm{~m}$, valor inferior ao modelado no período de quadratura $(-0,20 \mathrm{~m})$. No instante de preamar $\mathrm{c})$, o valor máximo modelado é de $1,13 \mathrm{~m}$, superior ao modelado no período de quadratura $(0,15 \mathrm{~m})$. Ao final do ciclo de enchente-vazante, no período de sizígia o valor mínimo modelado é de $-0,56 \mathrm{~m}$, inferior ao modelado no instante de quadratura $(-0,04 \mathrm{~m})$.
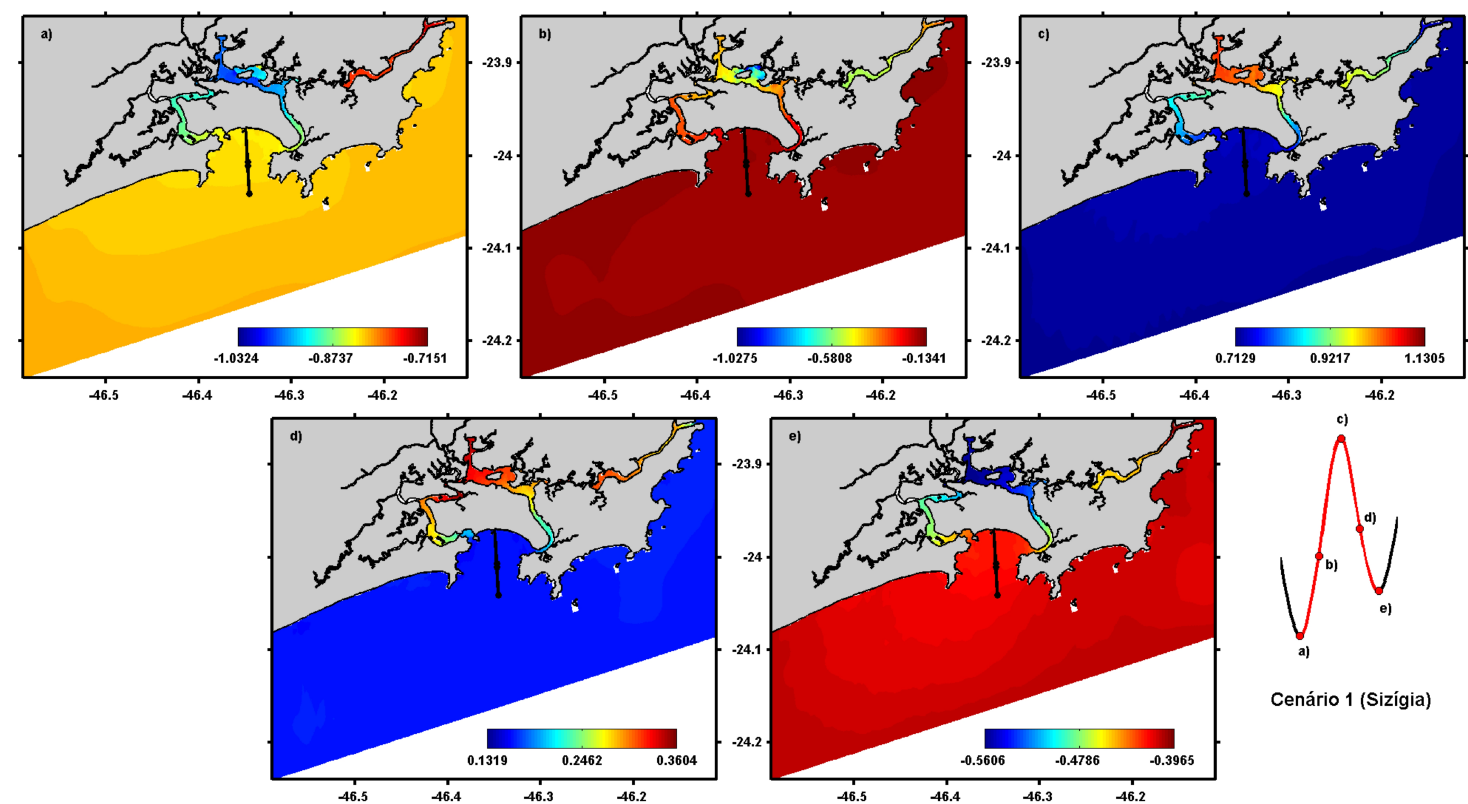

Figura 3.4: Variação do nível $(\mathrm{m})$ ao longo de um ciclo de enchente-vazante em maré de sizígia, para o cenário 1. Cada painel indica um instante de tempo, identificado pelo índice no canto superior esquerdo e a curva de nível em destaque.

O ciclo completo de variação do nível do mar para o período de 19 dias de simulação para o cenário 1 pode ser observado na Figura 3.5. Nesta figura, está mostrada a evolução temporal do nível do mar na posição $23,95^{\circ} \mathrm{S}, 46,30^{\circ} \mathrm{O}$ (local de instalação de marégrafo da DHN no Porto de Santos). Observa-se oscilação semidiurna (dois ciclos de enchente-vazante de maré por dia), com períodos consecutivos de sizígia-quadratura-sizígia. Em períodos de quadratura a amplitude mínima é de 0,25 m e, em períodos de sizígia, a amplitude máxima modelada é de 1,95 m.

Para os cenários 2 e 3, comparativamente com o cenário 1, foram obtidas diferenças mínimas para o campo de elevação da superfície livre, tendo ordem de $10^{-3} \mathrm{~m}$ e $10^{-2}$, respectivamente. Estas pequenas variações foram modeladas tanto em momentos de enchente quanto de vazante, nos períodos de sizígia e quadratura. Tais resultados serão omitidos pela similaridade apresentada com as Figuras 3.3, 3.4 e 3.5. 




Figura 3.5: Variação do nível do mar na posição $23,95^{\circ} \mathrm{S}, 46,30^{\circ} \mathrm{O}$ para o cenário 1. 


\subsubsection{Velocidade}

Conforme a sequência definida, serão apresentados resultados para períodos de quadratura e sizígia de maré. Para cada período de maré, serão apresentados os instantes de baixamar e preamar, respectivamente, para a camada superficial e de fundo.

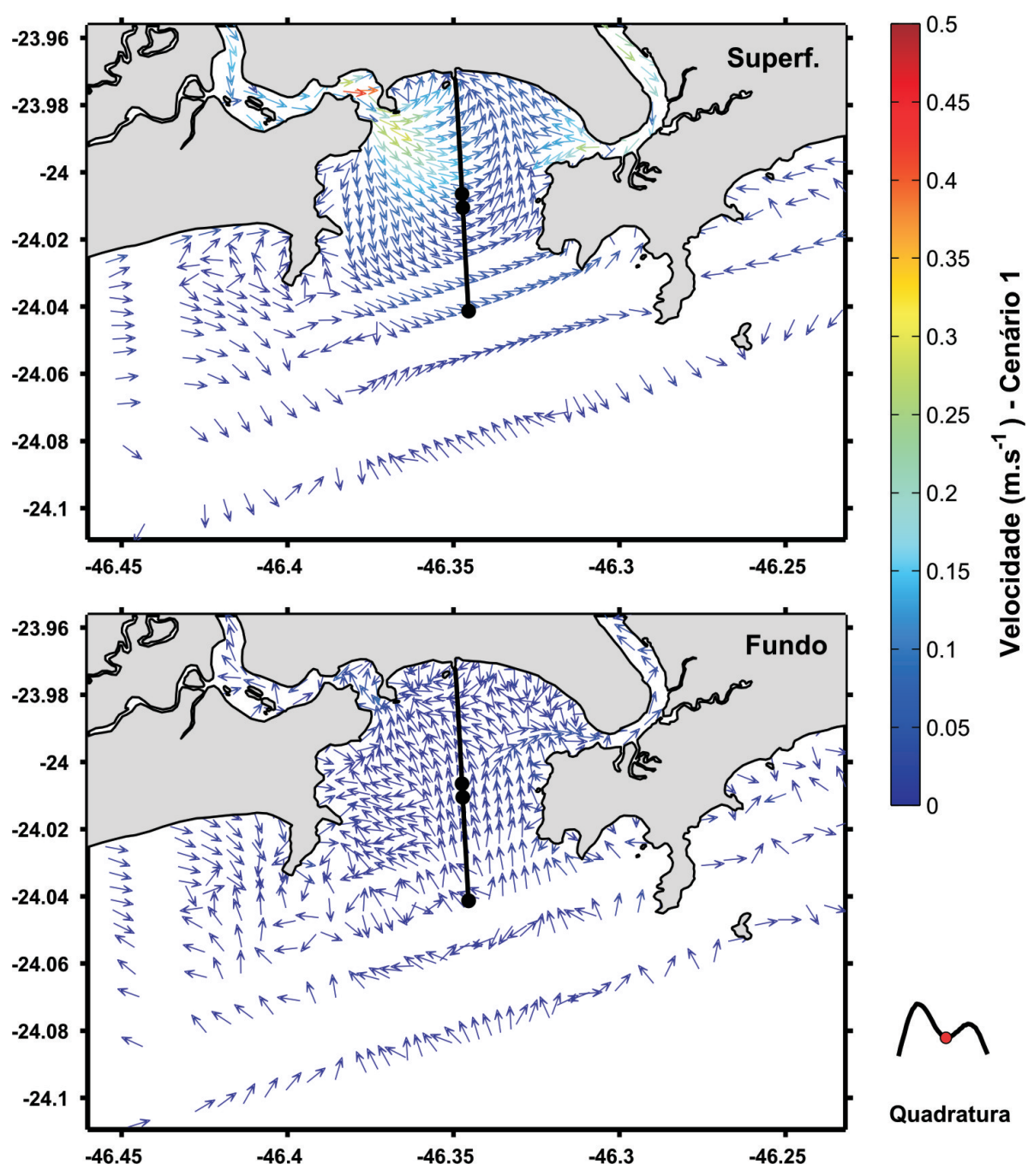

Figura 3.6: Campos de velocidade na superfície (superior) e fundo (inferior) para instante de baixamar em período de quadratura para o cenário 1. Os vetores indicam a direção das correntes. As cores correspondem as magnitudes. Estão plotados 1 a cada 4 vetores.

Na Figura 3.6 é apresentado o resultado de velocidade para o cenário 1, durante instante de baixamar em período de quadratura. Em superfície são modeladas as maiores velocidades na desembocadura do CSV na BS $\left(0,50 \mathrm{~m} . \mathrm{s}^{-1}\right)$, campo este caracterizado pela forma de leque causada pela divergência das correntes. Do lado oposto, na desembocadura do CP, as intensidades também são altas $\left(0,30 \mathrm{~m} \cdot \mathrm{s}^{-1}\right)$. O encontro dessas duas descargas faz com que, em superfície, ocorram movimentos anticiclônicos na BS, com a saída de água ocorrendo principalmente a oeste da entrada 
desta. Na camada de fundo, as magnitudes decrescem sensivelmente, podendo-se destacar a entrada de água para o AES por ambos canais.

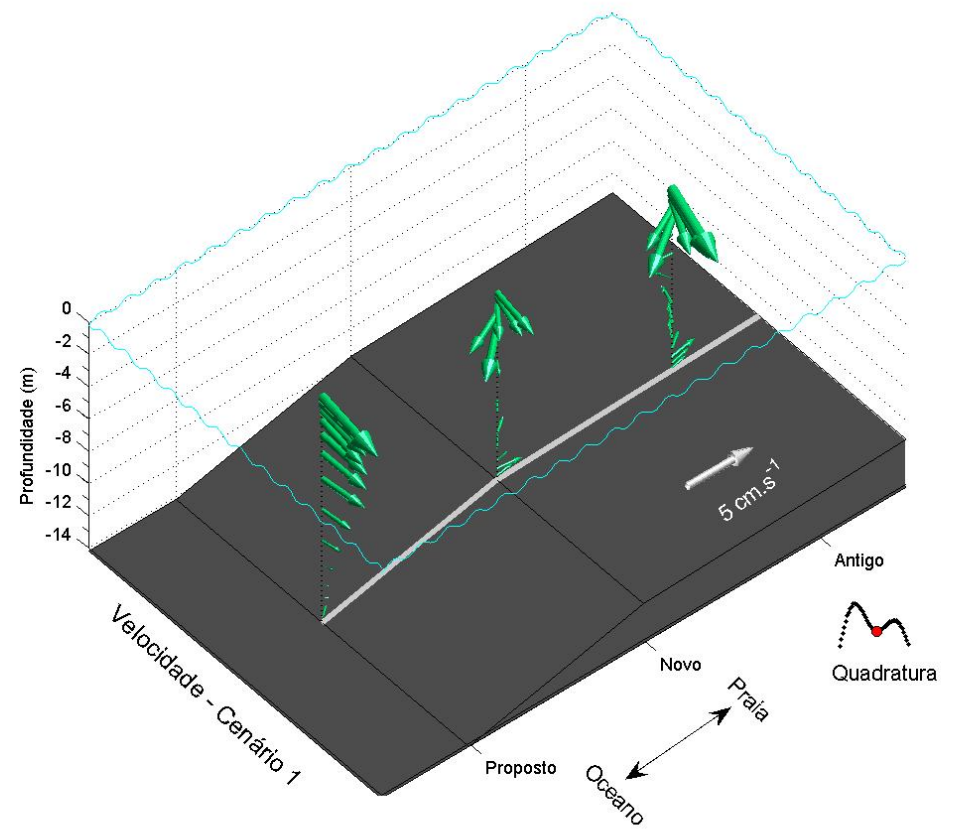

Figura 3.7: Perfis tridimensionais de velocidade em instante de baixamar em período de quadratura para o cenário 1 nos locais de lançamento de efluentes dos projetos antigo, novo e proposto.

A Figura 3.7 apresenta o campo tridimensonal de correntes nos locais de lançamento de efluentes nos projetos antigo, novo e proposto para o instante de baixamar em período de quadratura para o cenário 1. Na região dos dois projetos localizados no interior da BS (antigo e novo), as correntes superficiais apresentam direção leste-sudeste, ocorrendo inversão nas camadas intermediárias. A camada de fundo apresenta direção norte, para o interior da BS. No local do projeto proposto, por toda a coluna a direção da corrente é leste. Nos três pontos, a magnitude das correntes decresce da superfície ao fundo. As velocidades superficiais são da ordem de $10^{-2} \mathrm{~m} \cdot \mathrm{s}^{-1}$, e as velocidades próximas ao fundo são próximas à $0,00 \mathrm{~m} \cdot \mathrm{s}^{-1}$.

As mesmas feições modeladas em baixamar (Figura 3.6) podem ser destacadas em momento de preamar, porém com magnitudes alteradas. No instante de preamar, em superfície, as magnitudes das correntes geradas pelas descargas dos CSV e CP são menores, fazendo com que o giro anticiclônico modelado apresente características mais robustas, com ganhos de velocidade nas porções periféricas do giro (entrada e fundos da BS). Na camada de fundo, as características de baixamar são mantidas, com decréscimo da intensidade das correntes. Esta mudança nas magnitudes das correntes pode ser observada nos campos tridimensionais mostrados na Figura 3.8 , 


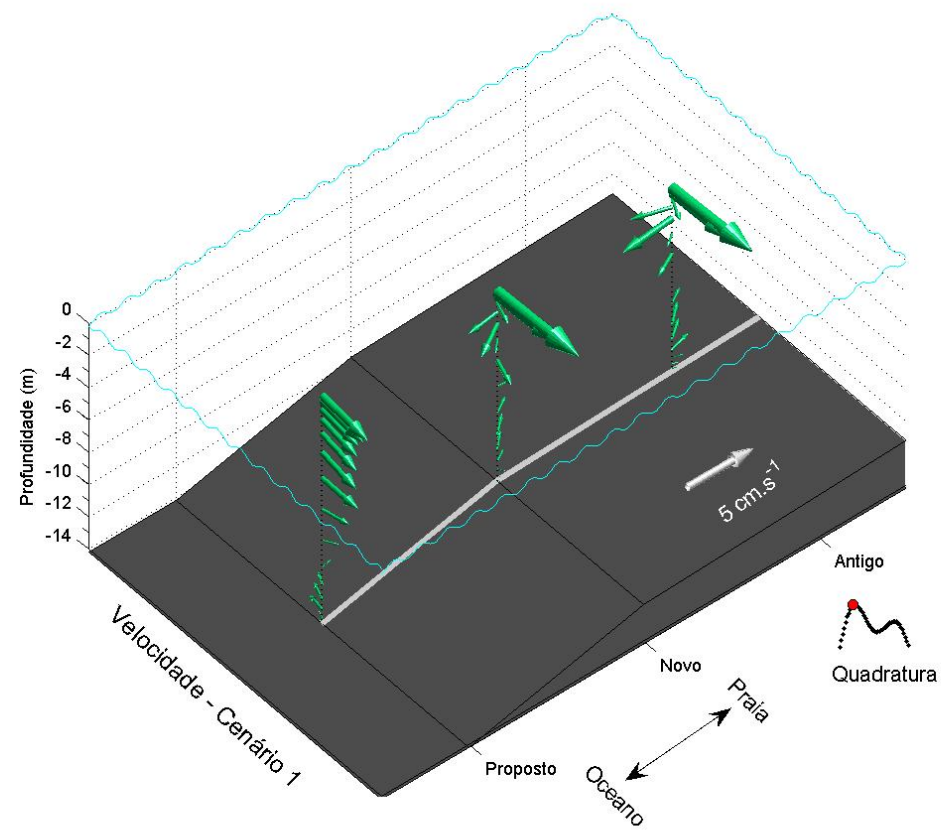

Figura 3.8: Perfis tridimensionais de velocidade em instante de preamar em período de quadratura para o cenário 1 nos locais de lançamento de efluentes dos projetos antigo, novo e proposto.

apresentando valores da ordem de $10^{-1} \mathrm{~m} . \mathrm{s}^{-1}$. Como os projetos antigo e novo se localizam próximo à saída da BS, porção periférica do giro anticiclônico modelado em superfície apresenta as magnitudes das correntes maiores quando comparada ao instante de baixamar (Figura 3.7).

No instante de baixamar de sizígia do cenário 1, em superfície são modeladas feições similares ao momento de baixamar de quadratura (Figura 3.6) porém com magnitudes significativamente maiores. Neste instante, no interior da BS, as maiores magnitudes para as correntes são modeladas em subsuperfície (ordem de $10^{-1} \mathrm{~m} . \mathrm{s}^{-1}$ ). $\mathrm{Na}$ camada de fundo, as magnitudes decrescem sensivelmente. A Figura 3.9 apresenta os perfis verticais de velocidade nos locais de lançamento dos projetos. Nota-se que nos pontos situados no interior da BS (projetos antigo e novo), as direções predominantes são para sul-sudoeste, sugerindo grande influência da descarga proveniente dos CSV e CP.

No instante de preamar de sizígia do cenário 1 (Figura 3.10), características diferentes das modeladas em período de baixamar foram obtidas. Na camada superficial, as descargas dos CSV e CP opõem-se ao fluxo proveniente da região externa à BS, fazendo com que nos locais de lançamento de efluentes dos projetos antigo e novo, localizados no interior da BS, as velocidades apontem para oeste. Na camada de fundo, foram modelados movimentos em direção ao AES. Conforme aumenta-se a 


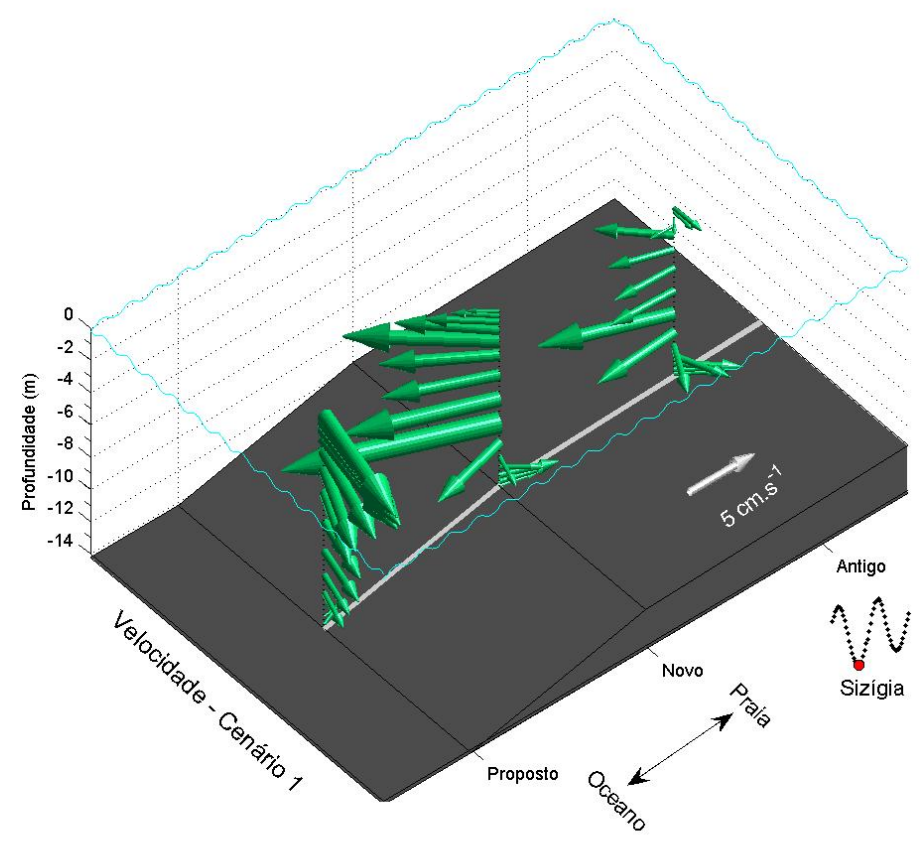

Figura 3.9: Perfis tridimensionais de velocidade em instante de baixamar em período de sizígia para o cenário 1 nos locais de lançamento de efluentes dos projetos antigo, novo e proposto.

profundidade, o local de convergência entre os fluxos provenientes do estuário e da área externa à BS desloca-se estuário acima. 

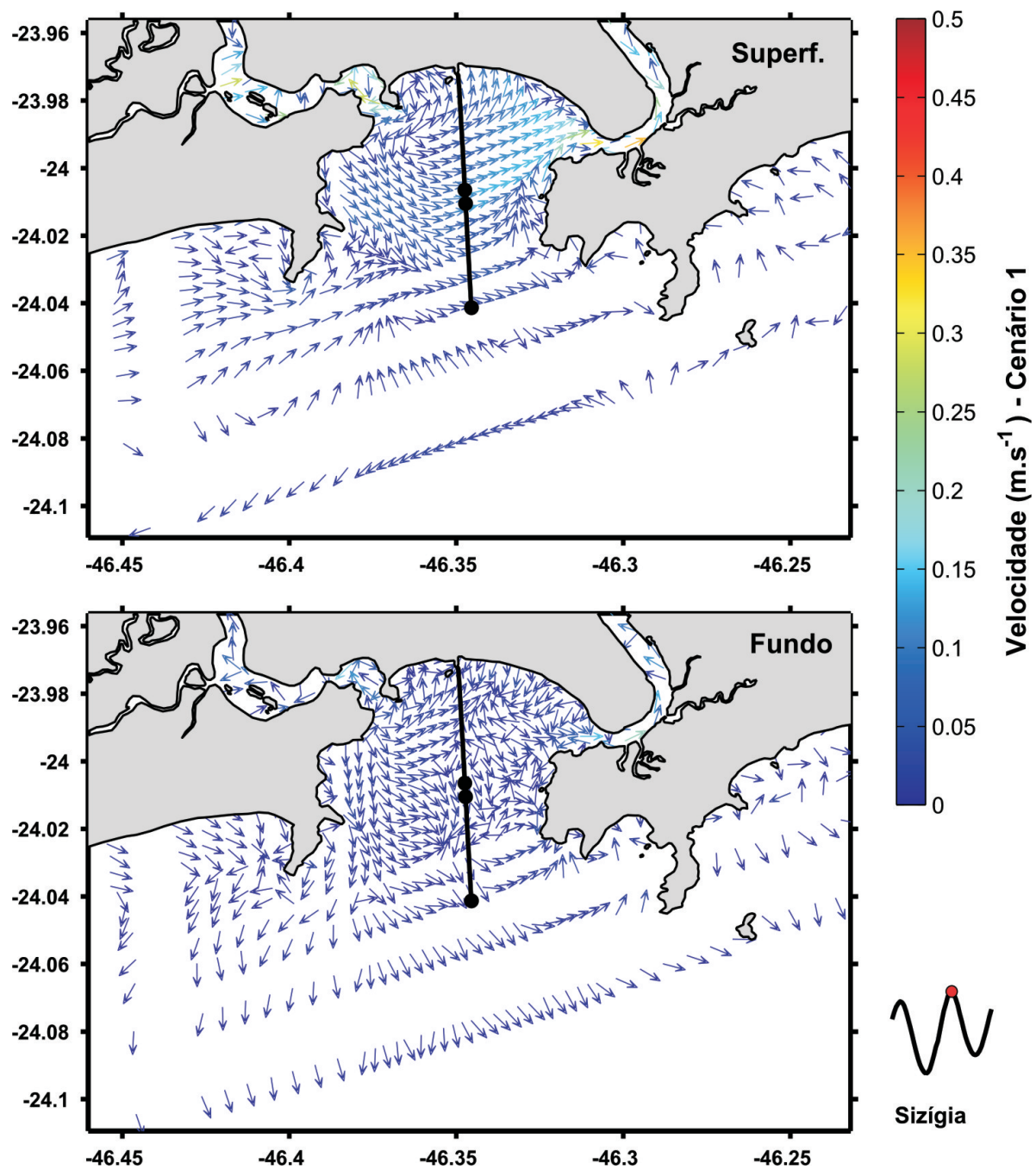

Figura 3.10: Campos de velocidade na superfície (superior) e fundo (inferior) para instante de preamar em período de sizígia para o cenário 1. Os vetores indicam a direção das correntes. As cores correspondem as magnitudes. Estão plotados 1 a cada 4 vetores. 
O campo de velocidades para o instante de baixamar de quadratura, no cenário 2 (não mostrado), quando comparado com o cenário 1 (Figura 3.6), mostra diferenças significativas na camada de superfície. Neste cenário com vento médio, o giro anticiclônico ocupa maior parte da BS e as magnitudes das correntes são intensificadas no sentido sudeste, ganhando deslocamento preferencial para fora da BS. Na camada de fundo as feições modeladas são as mesmas identificadas no cenário 1.

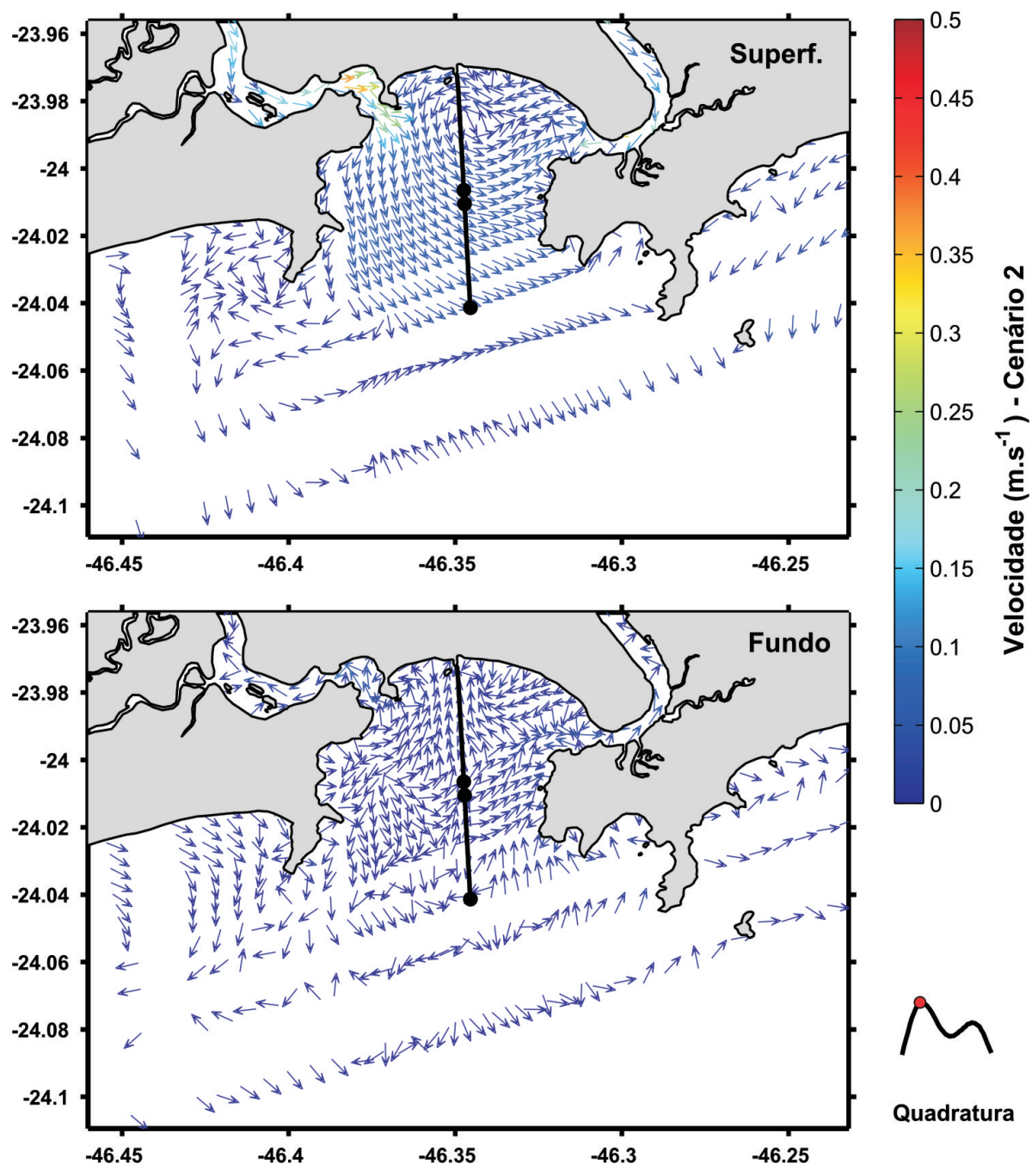

Figura 3.11: Campos de velocidade na superfície (superior) e fundo (inferior) para instante de preamar em período de quadratura para o cenário 2. Os vetores indicam a direção das correntes. As cores correspondem as magnitudes. Estão plotados 1 a cada 4 vetores.

Para o instante de preamar de quadratura (Figura 3.11) as variações comparadas ao cenário 1 também ocorrem principalmente na camada superficial. Novamente, neste instante de tempo foi modelado um giro anticiclônico na BS, com as correntes ganhando intensidade no sentido sudeste, para fora da BS. Na camada de fundo, as feições são similares às descritas para o cenário 1. Nos locais de lançamento de efluentes (projetos antigo, novo e proposto), observa-se em superfície o deslocamento 
das correntes em direção sul-sudoeste (Figura 3.12).

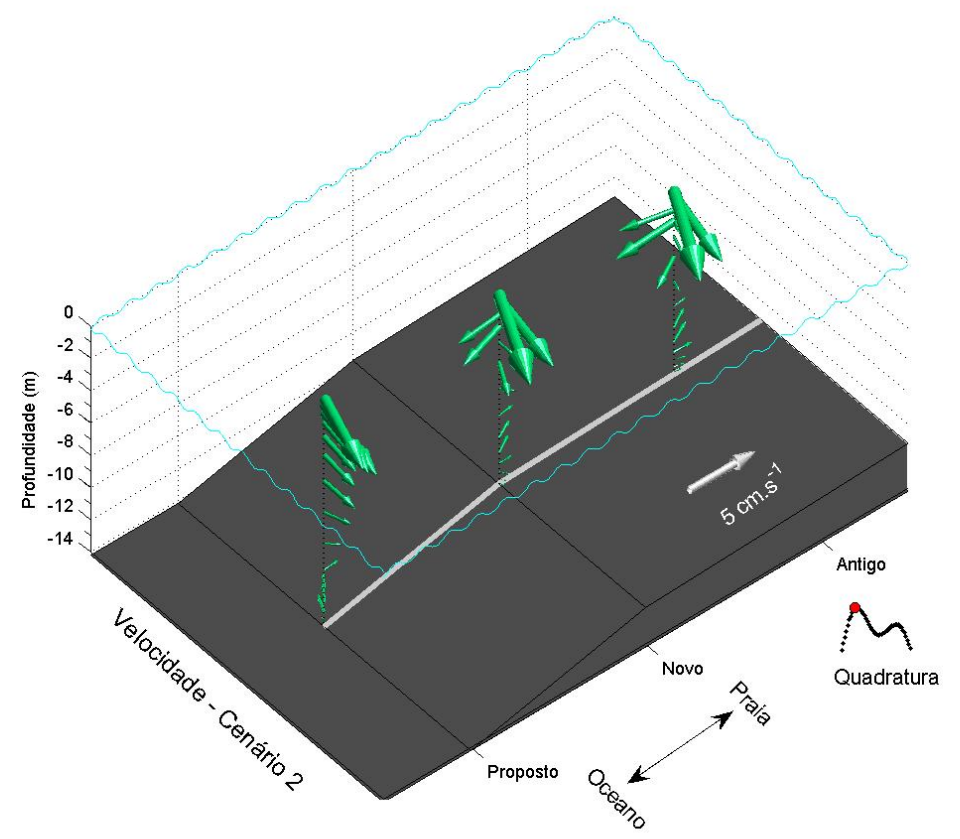

Figura 3.12: Perfis tridimensionais de velocidade em instante de preamar em período de quadratura para o cenário 2 nos locais de lançamento de efluentes dos projetos antigo, novo e proposto.

No instante de baixamar de sizígia do cenário 2, as comparações feitas sobre os experimentos dos cenários 1 e 2 em período de quadratura podem ser repetidas. As maiores modificações modeladas ocorrem na camada superficial, com aumento da intensidade das correntes na direção sudeste e fluxo predominantemente para fora da BS.

No instante de preamar de sizígia do cenário 2 (Figura 3.13), algumas diferenças consideráveis na camada superficial devem ser ressaltadas comparativamente ao cenário 1 (Figura 3.10): ocorre redirecionamento e intensificação do fluxo para sudeste. Nesta simulação, as correntes próximas à linha de costa no interior da BS perdem intensidade, havendo uma corrente ao longo da costa em sentido oeste. $\mathrm{O}$ giro anticiclônico continua predominante, assim como o fluxo para fora da BS. 

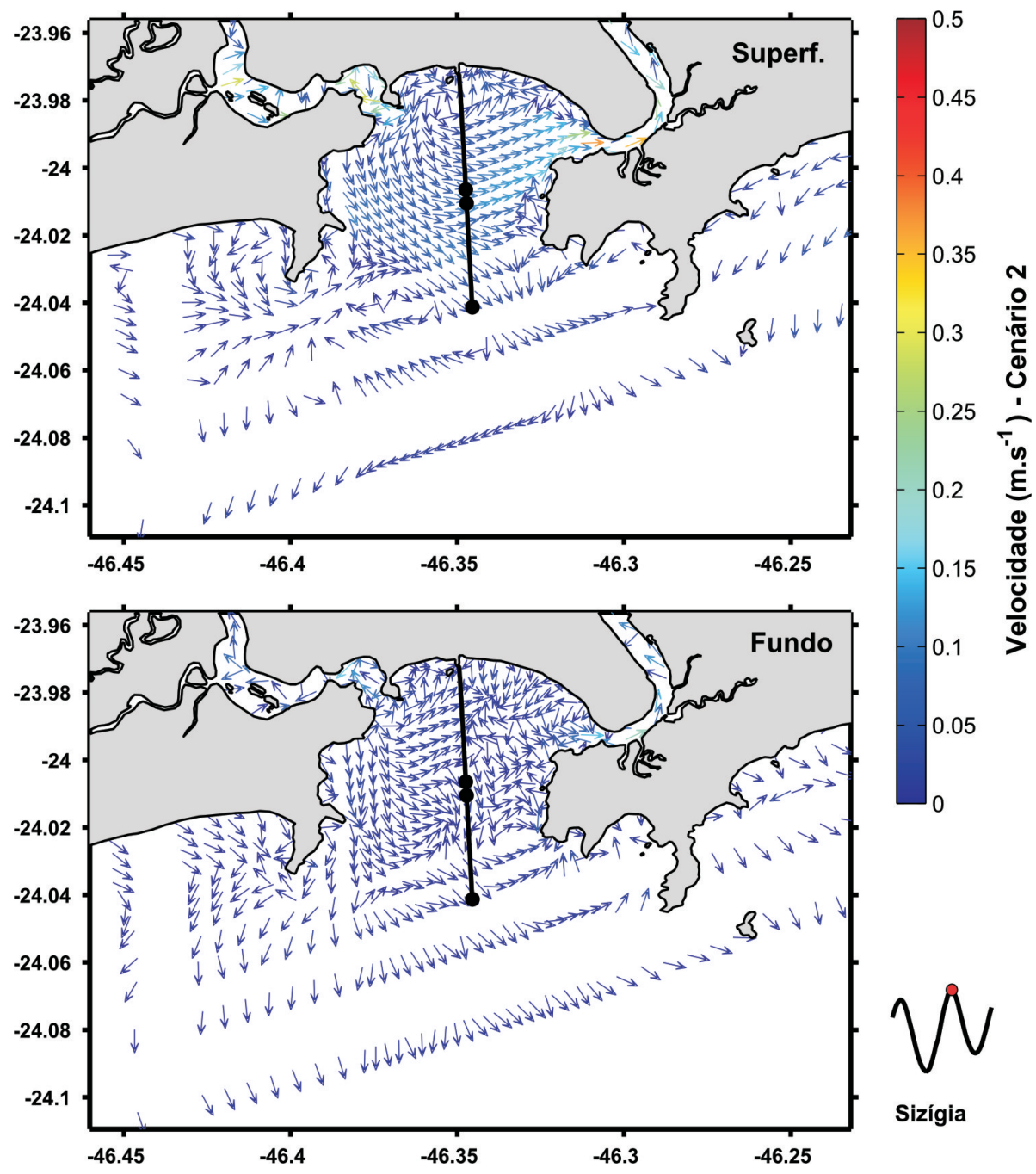

Figura 3.13: Campos de velocidade na superfície (superior) e fundo (inferior) para instante de preamar em período de sizígia para o cenário 2. Os vetores indicam a direção das correntes. As cores correspondem as magnitudes. Estão plotados 1 a cada 4 vetores. 
No instante de baixamar de quadratura do cenário 3 (Figura 3.14), comparativamente ao cenário 1 (Figura 3.6), diferenças significativas foram modeladas, principalmente na camada superficial. Nessa camada, ocorrem movimentos predominantes para dentro da BS, fazendo com que as correntes originadas pela descarga do CSV sejam orientadas para os fundos da BS, não apresentando mais a forma de leque modelada nos cenários 1 (Figura 3.6) e 2. Na camada de fundo ocorre diminuição da intensidade da velocidade, porém estas são ainda superiores aquelas modeladas nos cenários 1 e 2.

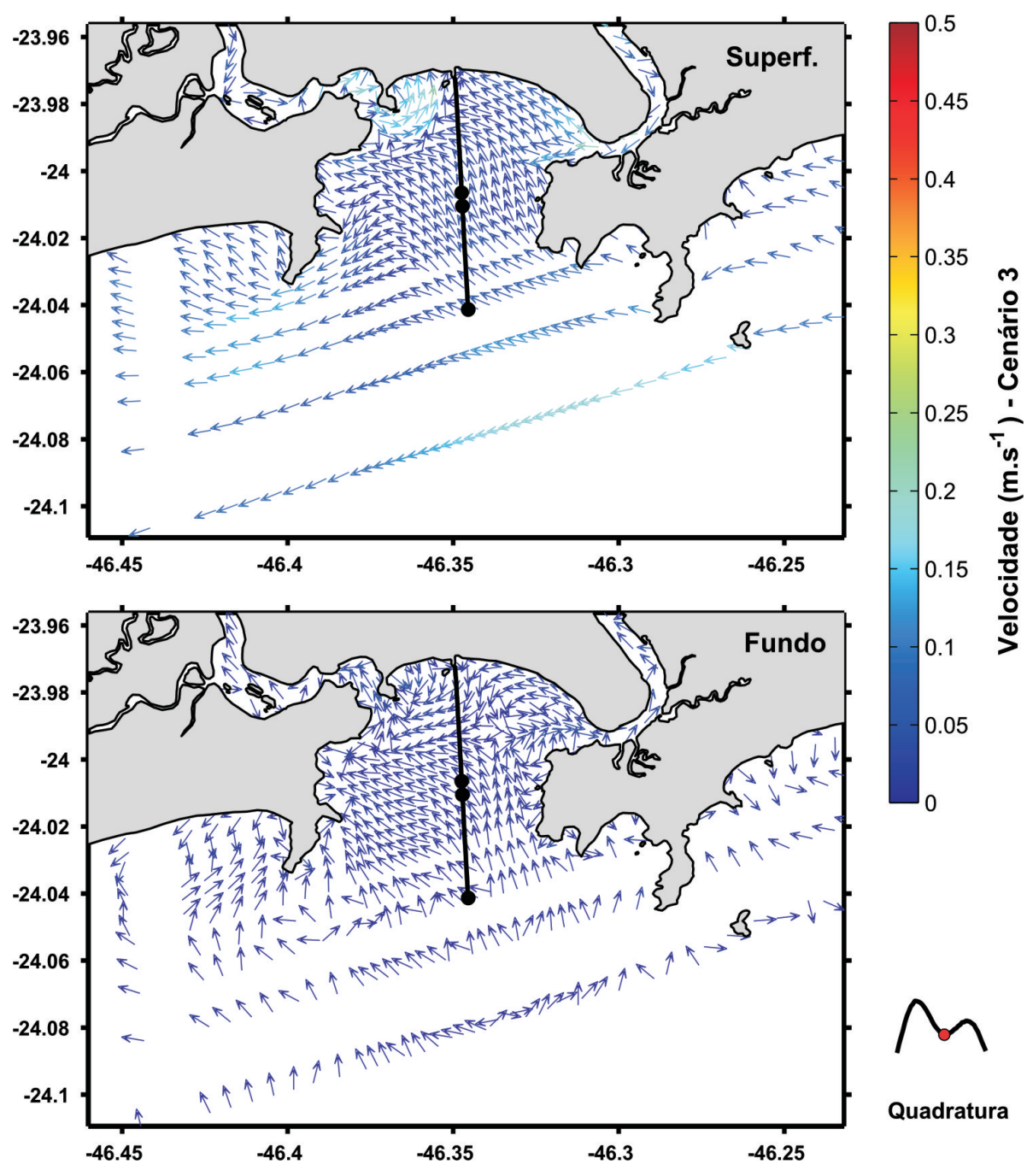

Figura 3.14: Campos de velocidade na superfície (superior) e fundo (inferior) para instante de baixamar em período de quadratura para o cenário 3. Os vetores indicam a direção das correntes. As cores correspondem as magnitudes. Estão plotados 1 a cada 4 vetores.

No instante de preamar de quadratura do cenário 3, os resultados (não mostrados) foram similares àqueles do instante de baixamar; porém, a convergência entre os fluxos proveniente da área externa à BS e do CSV ocorre no interior deste. Na camada de fundo, resultados muito parecidos aos do cenário 1 forma modelados. 


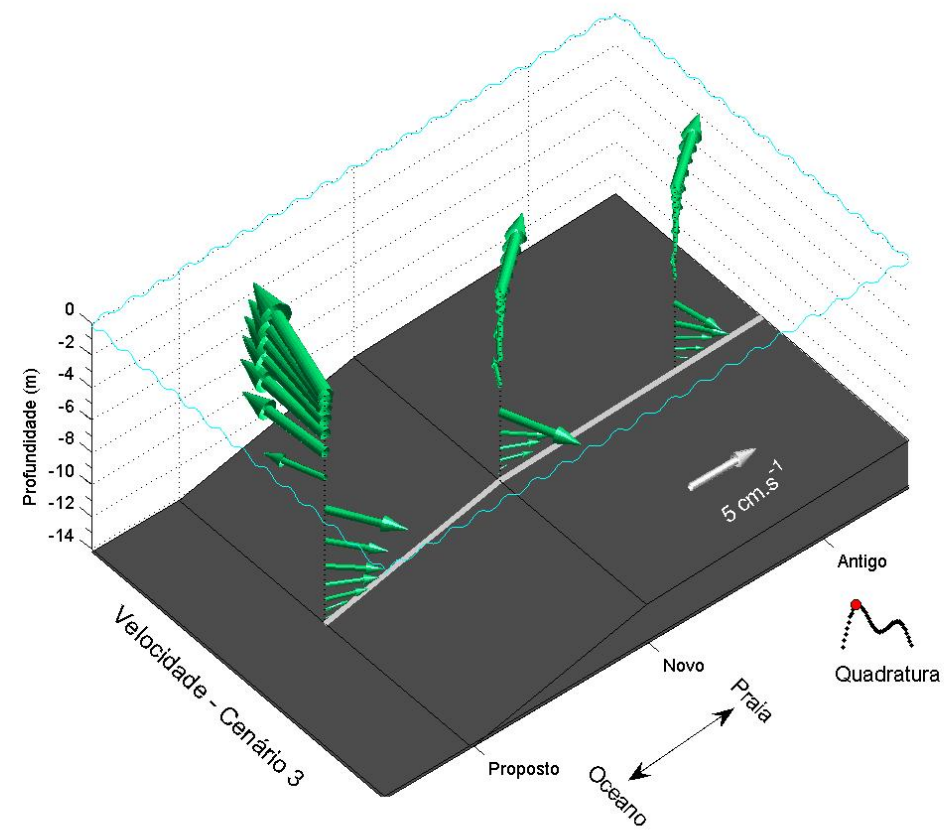

Figura 3.15: Perfis tridimensionais de velocidade em instante de preamar em período de quadratura para o cenário 3 nos locais de lançamento de efluentes dos projetos antigo, novo e proposto.

Nos locais de lançamento de efluentes nos projetos antigo e novo, no interior da BS, destaca-se em superfície as correntes orientadas para os fundos da BS. No local de lançamento do projeto proposto, as correntes superficiais estão orientadas para oeste, opostas à direção modelada no cenário 1 (Figura 3.8).

No instante de baixamar de sizígia do cenário 3 (Figura 3.16), as características são similares às modeladas no cenário 1 . Porém, desde que as correntes que entram na BS apresentam maior magnitude que o cenário sem vento (cenário 1), as feições, como por exemplo a forma de leque formada pela descarga do CSV, apresentam menores magnitudes. Concomitantemente, tanto em superfície quanto em profundidade, as estruturas estão deslocadas no sentido noroeste, quando comparado ao cenário 1.

No instante de preamar de sizígia do cenário 3 (Figura 3.17), em superfície foram modeladas correntes predominantemente em direção aos fundos da BS. Em todos os níveis ocorre fluxo predominante estuário acima, à partir dos CSV e CP. Na camada de fundo, na porção leste da BS, ocorre fluxo predominante para fora desta. 

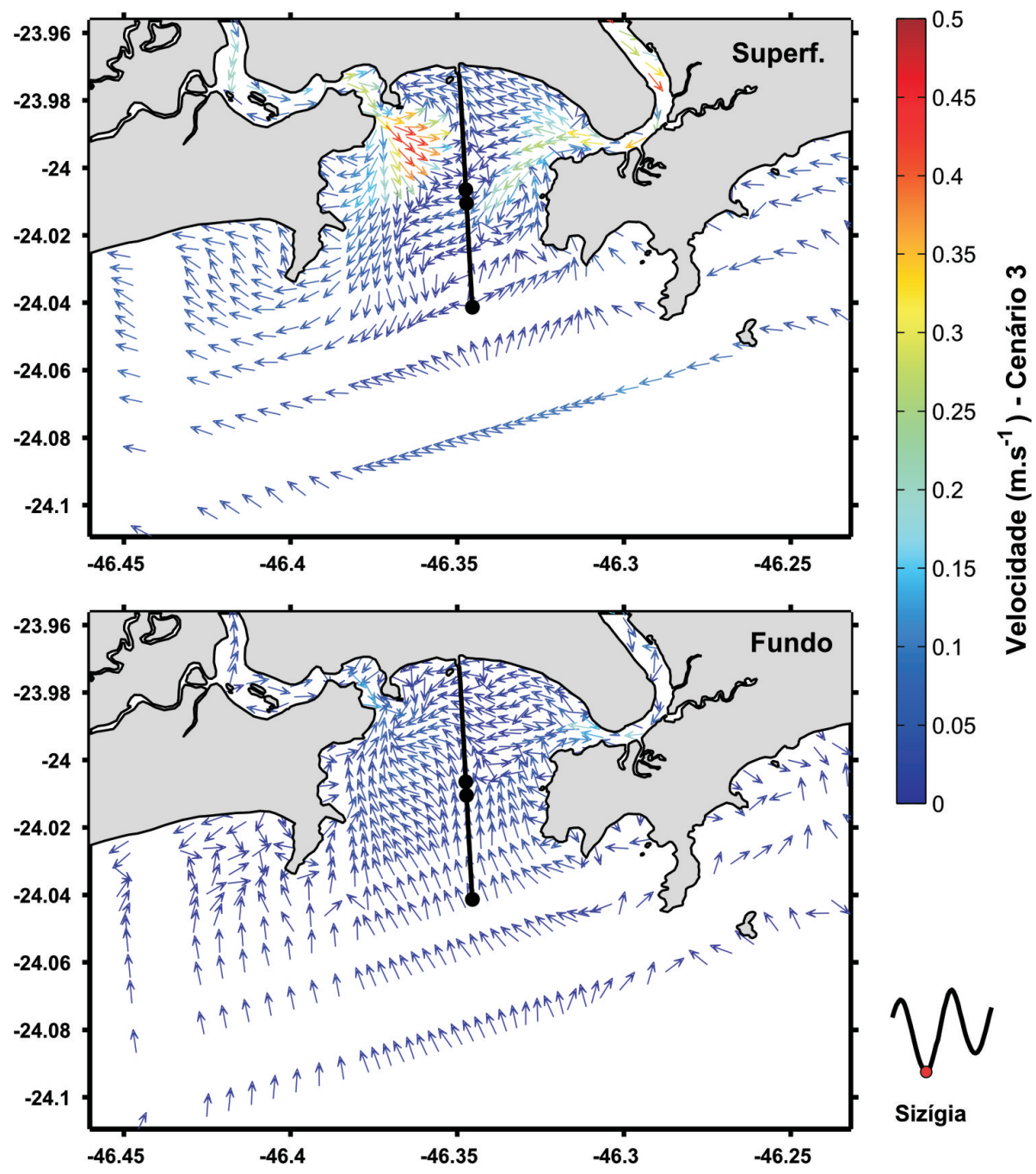

Figura 3.16: Campos de velocidade na superfície (superior) e fundo (inferior) para instante de baixamar em período de sizígia para o cenário 3.Os vetores indicam a direção das correntes. As cores correspondem as magnitudes. Estão plotados 1 a cada 4 vetores. 

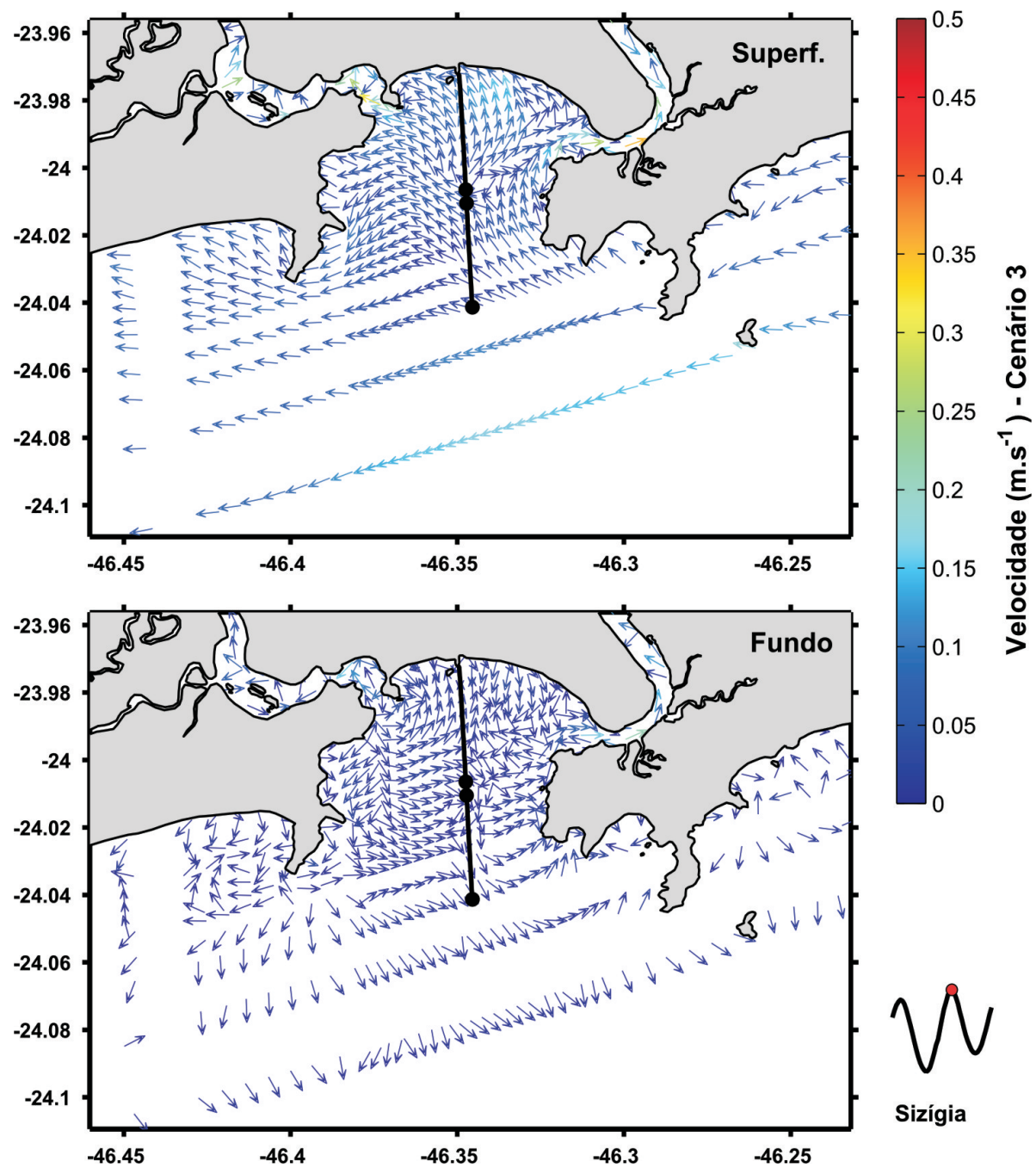

Figura 3.17: Campos de velocidade na superfície (superior) e fundo (inferior) para instante de preamar em período de sizígia para o cenário 3. Os vetores indicam a direção das correntes. As cores correspondem as magnitudes. Estão plotados 1 a cada 4 vetores. 


\subsubsection{Densidade}

Para cada período de maré (quadratura e sizígia), serão apresentados os resultados para os instantes de baixamar e preamar. Será mostrada a seção vertical de densidade ao longo do ESS e os perfis verticais nos locais de término do ESS nos três projetos: antigo, novo e proposto. Além disto, será apresentado o valor de estratificação bruta ("bulk stratification"), isto é, a diferença entra as densidades convencionais modeladas nas proximidades do fundo e na superfície (Castro (1996)).

A Figura 3.18 apresenta a distribuição horizontal de estratificação bruta para o cenário 1, durante instante de baixamar em período de quadratura. Os maiores valores estão na região central da BS (ao longo do ESS, com 1,00 kg.m ${ }^{-3}$ ), na desembocadura do $\operatorname{CSV}\left(3,50 \mathrm{~kg} \cdot \mathrm{m}^{-3}\right)$ e em direção à região marinha adjacente $\left(2,00-3,50 \mathrm{~kg} \cdot \mathrm{m}^{-3}\right)$. Na regiões mais rasas, os valores tendem a $0 \mathrm{~kg} \cdot \mathrm{m}^{-3}$.

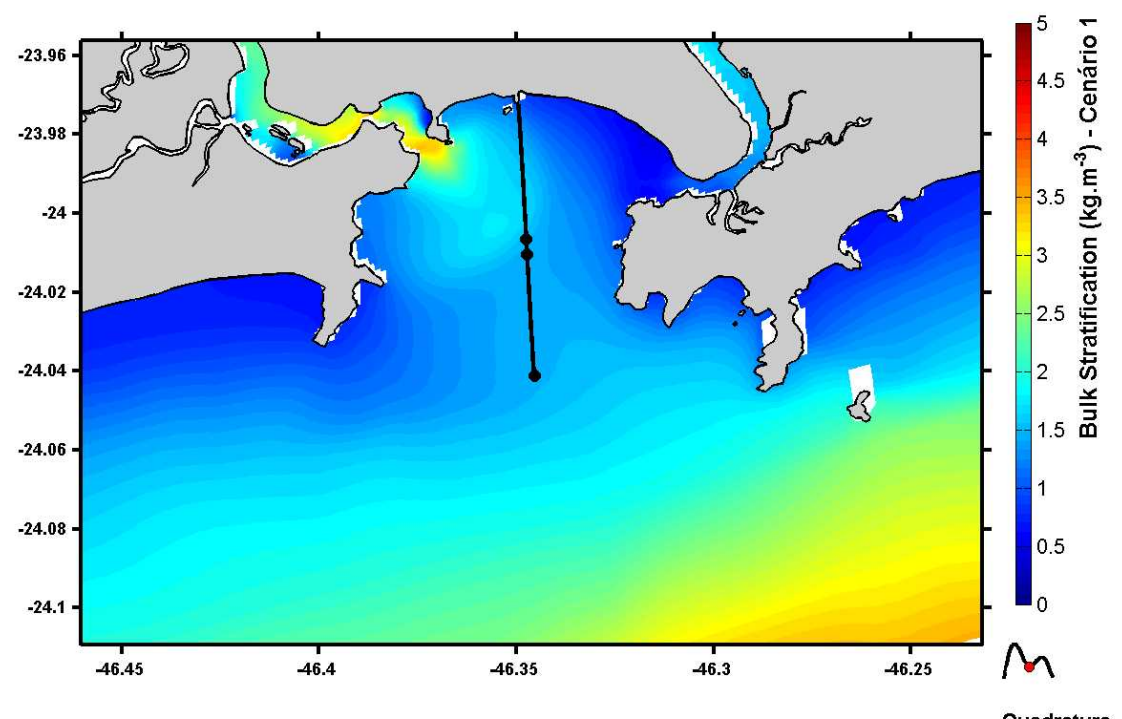

Figura 3.18: Campo de estratificação bruta ("bulk stratification") (kg.m ${ }^{-3}$ ) para instante de baixamar em período de quadratura para o cenário 1 .

A seção vertical de densidade para o instante de baixamar de quadratura no cenário 1 (Figura 3.19) revela a presença de uma pluma de baixa densidade (1021,40 kg. $\mathrm{m}^{-3}$ ), em superfície, até aproximadamente 4,00 km de distância ao longo do ESS, no local de lançamento de efluentes do projeto antigo. Esta pluma superficial de menor densidade faz com que na posição do lançamento de efluentes do projeto antigo o valor da estratificação bruta seja maior $\left(1,51 \mathrm{~kg} \cdot \mathrm{m}^{-3}\right)$ do que os valores modelados para os projetos novo $\left(1,45 \mathrm{~kg} \cdot \mathrm{m}^{-3}\right)$ e proposto $\left(1,46 \mathrm{~kg} \cdot \mathrm{m}^{-3}\right)$.

A distribuição horizontal da estratificação bruta para o instante de preamar de quadratura no cenário 1 (não apresentada) é similar àquela para o instante de baixamar (Figura 3.18); porém, a localização do núcleo de maior estratificação bruta 

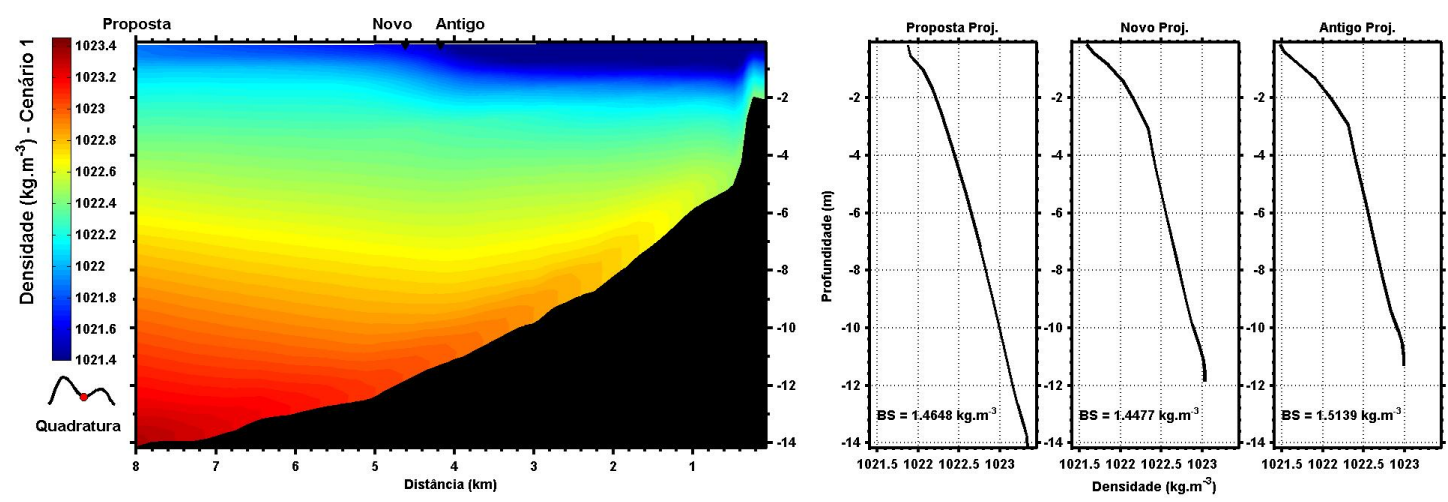

Figura 3.19: No painel da esquerda, seção vertical de densidade $\left(\mathrm{kg} \cdot \mathrm{m}^{-3}\right)$ ao longo do emissário submarino de Santos para instante de baixamar de quadratura no cenário 1. No painel da direita estão representados os perfis verticais ao final do emissário submarino de Santos para os três projetos: antigo, novo e proposto. O valor de BS representa a estratificação bruta ("bulk stratification").

$\left(3,50 \mathrm{~kg} \cdot \mathrm{m}^{-3}\right)$ desloca-se estuário adentro no CSV, forçado pelas águas provenientes da área marinha adjacente.

A diminuição da densidade superficial e o aumento da densidade de fundo, em momentos de baixamar, fazem com que os valores de estratificação bruta sofram alterações diferentes entre os projetos de acordo com sua distância à costa. O projeto proposto, que está localizado mais distante da costa, em momentos de baixamar de quadratura apresenta estratificação bruta de 1,46 kg.m ${ }^{-3}$, tendo este valor reduzido para 1,42 kg.m ${ }^{-3}$ em instante de preamar (Figura 3.20). A explicação é que no momento de preamar a camada de fundo apresentou a mesma densidade que no momento de baixamar, enquanto a camada superficial apresentou aumento da densidade. O projeto novo, localizado na parte intermediária, apresentou aumento da estratificação bruta (de 1,45 kg.m ${ }^{-3}$ para 1,48 kg.m ${ }^{-3}$ ), quando comparadas as duas fases de maré. Ou seja, houve manutenção da densidade na camada superficial e aumento da densidade na camada de fundo. O projeto antigo apresentou a mesma relação do projeto proposto, ou seja, redução da estratificação bruta em momento de preamar (1,49 kg.m $\left.{ }^{-3}\right)$ quando comparado ao instante de baixamar $\left(1,51 \mathrm{~kg} \cdot \mathrm{m}^{-3}\right)$.

O campo de estratificação bruta para o instante de baixamar de sizígia (Figura 3.21), quando comparado ao instante de baixamar de quadratura (Figura 3.18), apresenta algumas diferenças marcantes. Em sizígia, a região central da BS tem estratificação bruta semelhante às regiões mais costeiras (próximos a $0,00 \mathrm{~kg} \cdot \mathrm{m}^{-3}$ ) e os maiores valores modelados estão deslocados da desembocadura do CSV, estando mais próximos do ESS. Essa diminuição da estratificação bruta na região central da BS marca também a diminuição desta propriedade nos locais de projetos do ESS. Para o projeto proposto, a diminuição é de $0,18 \mathrm{~kg} \cdot \mathrm{m}^{-3}\left(1,46 \mathrm{~kg} \cdot \mathrm{m}^{-3}\right.$ em quadratura e 1,28 kg.m ${ }^{-3}$ em sizígia), para o projeto novo a diminuição é de $0,48 \mathrm{~kg} \cdot \mathrm{m}^{-3}(1,45$ 

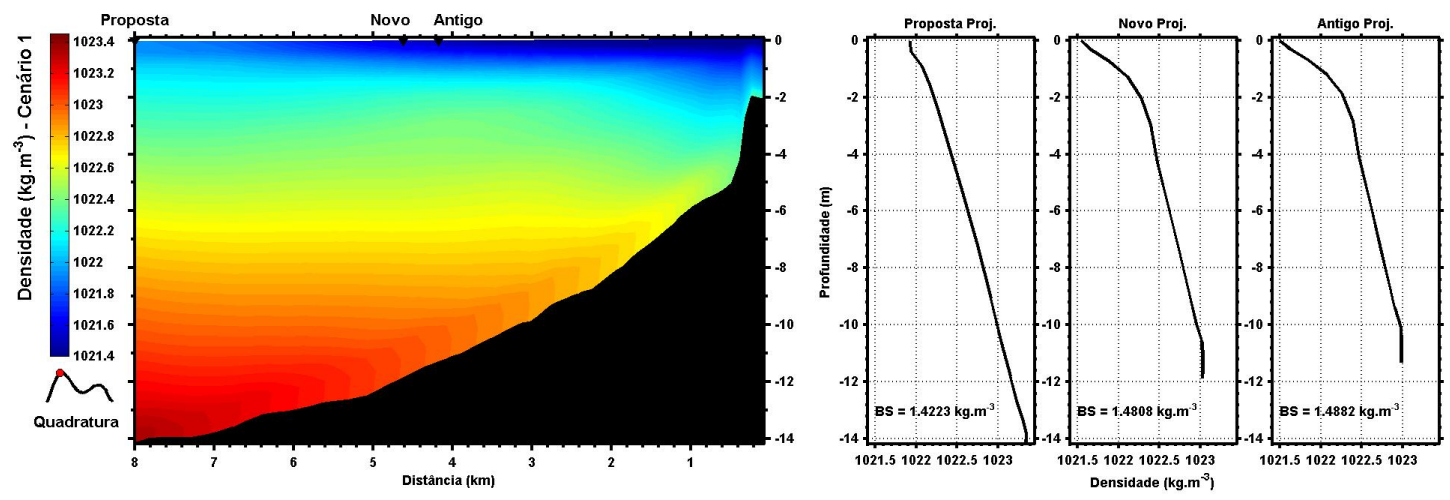

Figura 3.20: No painel da esquerda, seção vertical de densidade $\left(\mathrm{kg} \cdot \mathrm{m}^{-3}\right)$ ao longo do emissário submarino de Santos para instante de preamar de quadratura no cenário 1. No painel da direita estão representados os perfis vertical ao final do emissário submarino de Santos para os três projetos: antigo, novo e proposto. O valor de BS representa a estratificação bruta ("bulk stratification").

kg.m ${ }^{-3}$ para $\left.0,97 \mathrm{~kg} \cdot \mathrm{m}^{-3}\right)$ e o projeto antigo sofre diminuição de $0,54 \mathrm{~kg} \cdot \mathrm{m}^{-3}(1,51$ $\mathrm{kg} \cdot \mathrm{m}^{-3}$ para $\left.0,97 \mathrm{~kg} \cdot \mathrm{m}^{-3}\right)$.

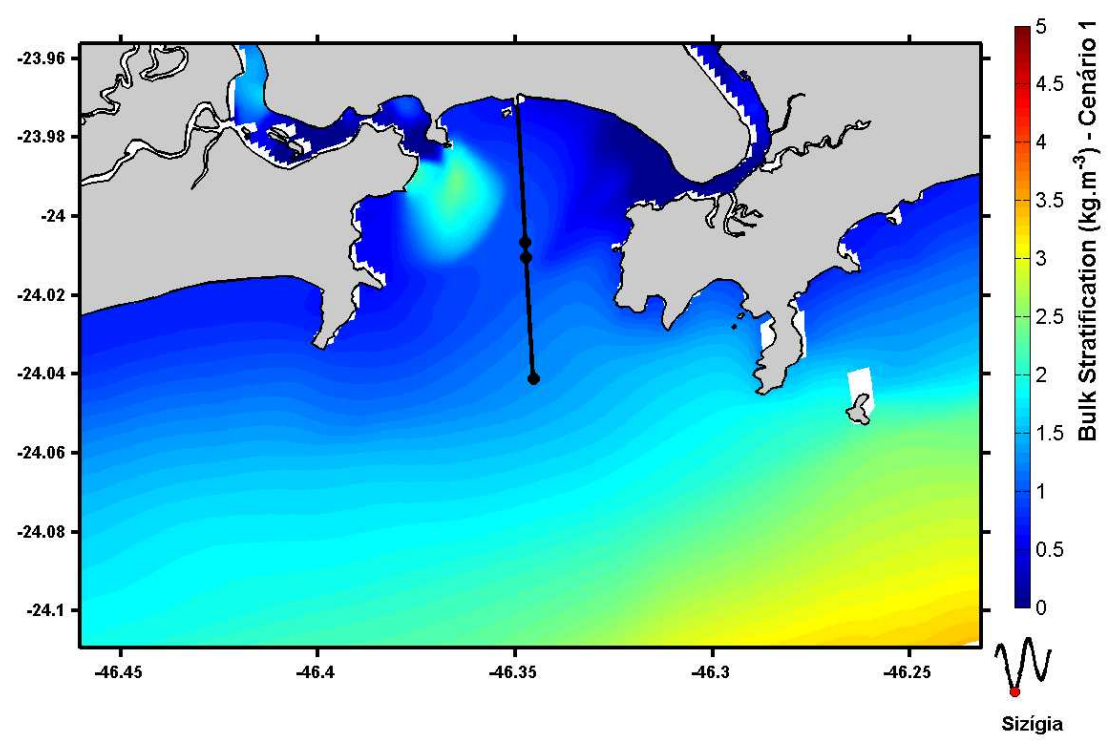

Figura 3.21: Campo de estratificação bruta ("bulk stratification") (kg.m ${ }^{-3}$ ) para instante de baixamar em período de sizígia para o cenário 1.

No instante de preamar de sizígia para o cenário 1 ocorre retração das águas provenientes do CSV e consequentemente deslocamento da região de alto valor de estratificação bruta para o interior deste. Esta retração é provocada pela entrada de água mais densa, proveniente da região marinha adjacente, na BS. Esta entrada de água mais densa faz com que ocorra aumento da diferença de densidade entre as camadas de superfície e fundo (Figura 3.22). Quando comparado ao instante de preamar, para o projeto proposto, o valor de $1,28 \mathrm{~kg} \cdot \mathrm{m}^{-3}$ é aumentado para 1,34 
$\mathrm{kg} \cdot \mathrm{m}^{-3}$, o projeto novo sofre variação de $0,97 \mathrm{~kg} \cdot \mathrm{m}^{-3}$ para $1,14 \mathrm{~kg} \cdot \mathrm{m}^{-3}$ e, para o projeto antigo, esta variação é de $0,97 \mathrm{~kg} \cdot \mathrm{m}^{-3}$ para $1,18 \mathrm{~kg} \cdot \mathrm{m}^{-3}$.

Quando comparados os períodos de quadratura e sizígia no cenário 1, tem-se que nestes últimos as variações entre momentos de baixamar e preamar ocorrem de forma mais brusca, afetando igualmente o perfil de estratificação para todos os projetos. Já em momentos de quadratura, esta variação é menor, e os projetos próximos à costa têm estratificações diferentes quando comparados aos projetos mais distantes desta.
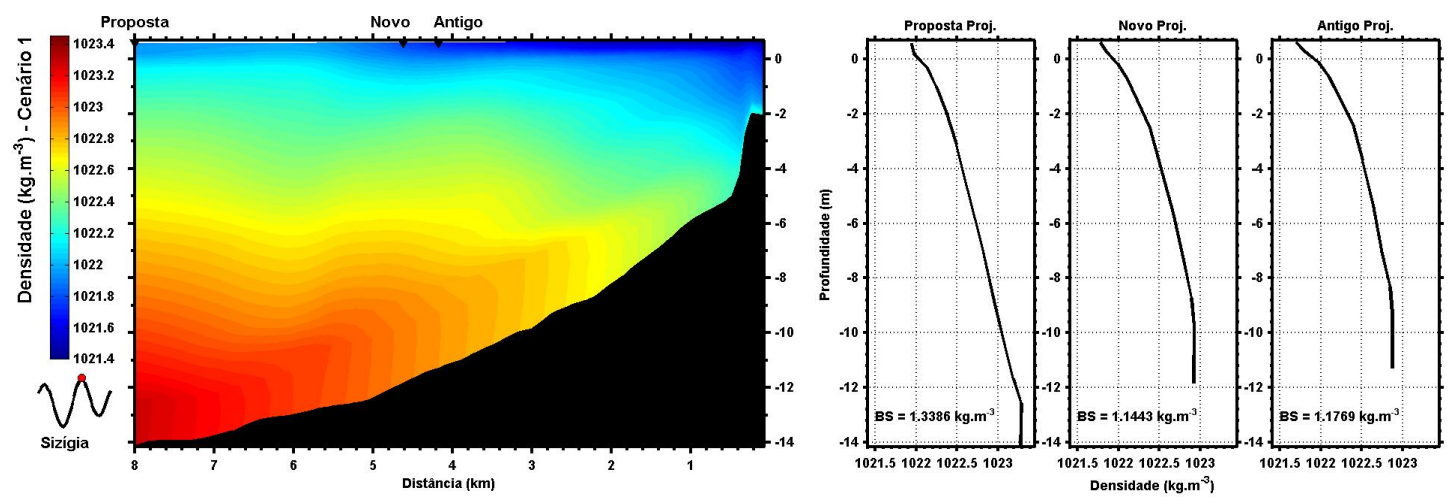

Figura 3.22: No painel da esquerda, seção vertical de densidade $\left(\mathrm{kg} . \mathrm{m}^{-3}\right)$ ao longo do emissário submarino de Santos para instante de preamar de sizígia no cenário 1. No painel da direita estão representados os perfis vertical ao final do emissário submarino de Santos para os três projetos: antigo, novo e proposto. O valor de BS representa a estratificação bruta ("bulk stratification").

O campo de estratificação bruta para o instante de baixamar de quadratura no cenário 2 é muito similar ao apresentado para o cenário 1 (Figura 3.18). Quando comparados os perfis verticais de densidade entre os cenários 1 e 2 , verifica-se diminuição da estratificação bruta para o projeto proposto e aumento deste valor para os projetos novo e antigo. Para o cenário 2, o projeto proposto apresenta estratificação bruta de $1,33 \mathrm{~kg} \cdot \mathrm{m}^{-3}$, o projeto novo de $1,48 \mathrm{~kg} \cdot \mathrm{m}^{-3}$ e o projeto antigo de 1,55 kg. $\mathrm{m}^{-3}$.

A estrutura horizontal de estratificação bruta modelada para o cenário 2 (Figuras 3.23 é muito similar à modelada para o cenário 1. A diferença principal está nos valores modelados na região do ESS, onde, no cenário 2, as estratificação bruta são menores. Quando comparados os perfis verticais de densidade do cenário 2 com os do cenário 1 (Figura 3.20 ), nota-se que em todos os projetos ocorreu diminuição da estratificação bruta, conforme descrito para a distribuição horizontal. A diminuição apresentada para o projeto proposto é de $0,13 \mathrm{~kg} \cdot \mathrm{m}^{-3}$ (de $1,42 \mathrm{~kg} \cdot \mathrm{m}^{-3}$ para 1,29 $\mathrm{kg} \cdot \mathrm{m}^{-3}$ ). Este valor para o projeto novo é de $0,11 \mathrm{~kg} \cdot \mathrm{m}^{-3}$ (no cenário 1 o valor é de 1,48 kg.m ${ }^{-3}$, e no cenário 2 de $1,37 \mathrm{~kg} \cdot \mathrm{m}^{-3}$ ). O projeto antigo apresentou redução da mesma magnitude, $0,11 \mathrm{~kg} \cdot \mathrm{m}^{-3}$, sendo o valor do cenário 1 de 1,49 kg.m ${ }^{-3}$ e 
do cenário 2, $1,38 \mathrm{~kg} \cdot \mathrm{m}^{-3}$. Ainda, quando comparadas as estratificações brutas entre instantes de baixamar e preamar de quadratura para o cenário 2, para todos os projetos os valores modelados em instantes de preamar são inferiores aos dos instantes de baixamar.

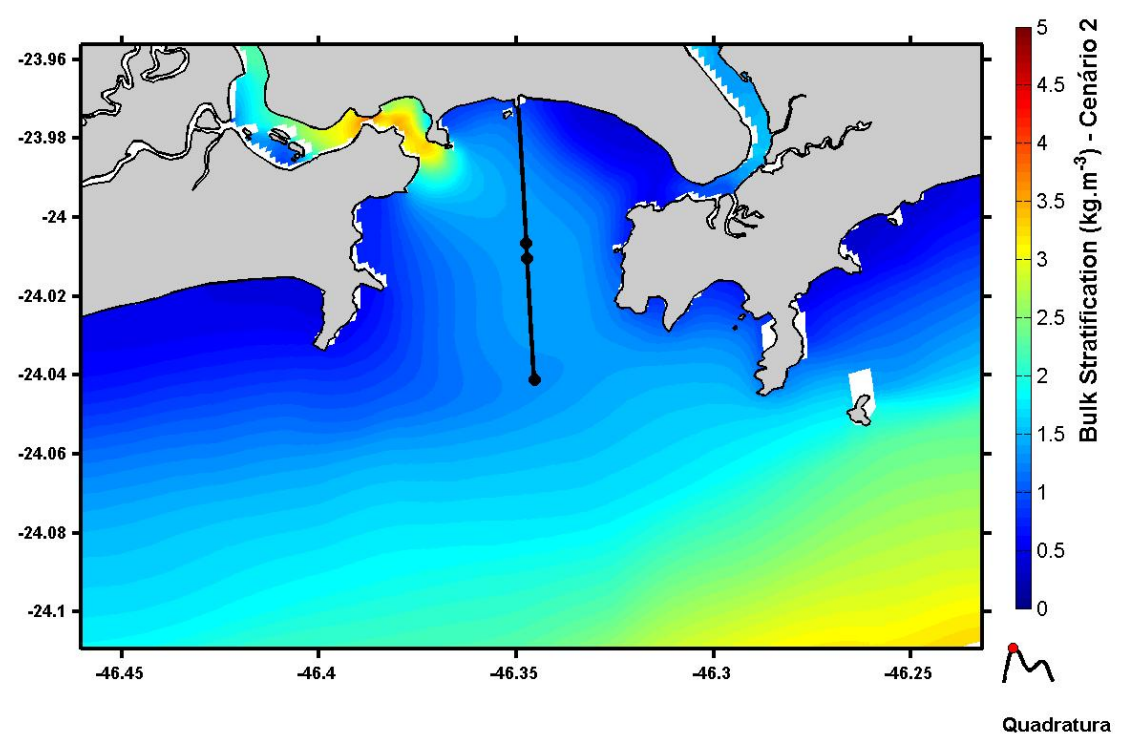

Figura 3.23: Campo de estratificação bruta ("bulk stratification") (kg.m ${ }^{-3}$ ) para instante de preamar em período de quadratura para o cenário 2.

A distribuição horizontal da estratificação bruta para o instante de baixamar de sizígia no cenário 2 apresenta grande similaridade com as características modeladas para o cenário 1 (Figura 3.21), com diminuições de valores na região próxima ao ESS. A estratificação bruta do cenário 2 em momento de baixamar de sizígia (Figura 3.24), quando comparada com o cenário 1 , apresenta diminuição para os três projetos. $\mathrm{O}$ valor modelado no cenário 2 para o projeto proposto é de $1,12 \mathrm{~kg} . \mathrm{m}^{-3}$, para o projeto novo de $0,89 \mathrm{~kg} \cdot \mathrm{m}^{-3}$, e para o projeto antigo $0,88 \mathrm{~kg} \cdot \mathrm{m}^{-3}$.

Novamente, conforme descrito para o instante de baixamar de sizígia no cenário 2, os valores da distribuição horizontal da estratificação bruta para o instante de preamar de sizígia, quando comparados os cenários 1 e 2 (Figura 3.25), apresentam grande similaridade. Porém no cenário 2, os valores na região do ESS apresentam-se relativamente reduzidos. No instante de preamar de sizígia no cenário 2, a estratificação bruta para o projeto proposto é de $1,13 \mathrm{~kg} \cdot \mathrm{m}^{-3}$, para o projeto novo de 1,04 $\mathrm{kg} \cdot \mathrm{m}^{-3}$ e para o projeto antigo $1,08 \mathrm{~kg} \cdot \mathrm{m}^{-3}$. Quando comparadas as estratificações brutas para os instantes de baixamar e preamar de sizígia para o cenário 2, diferentemente dos instantes de quadratura, os valores de preamar apresentaram valores menores que os instantes de baixamar.

O campo horizontal de estratificação bruta no instante de baixamar de quadratura do cenário 3 (Figura 3.26), apresenta valores relativamente menores, quando 

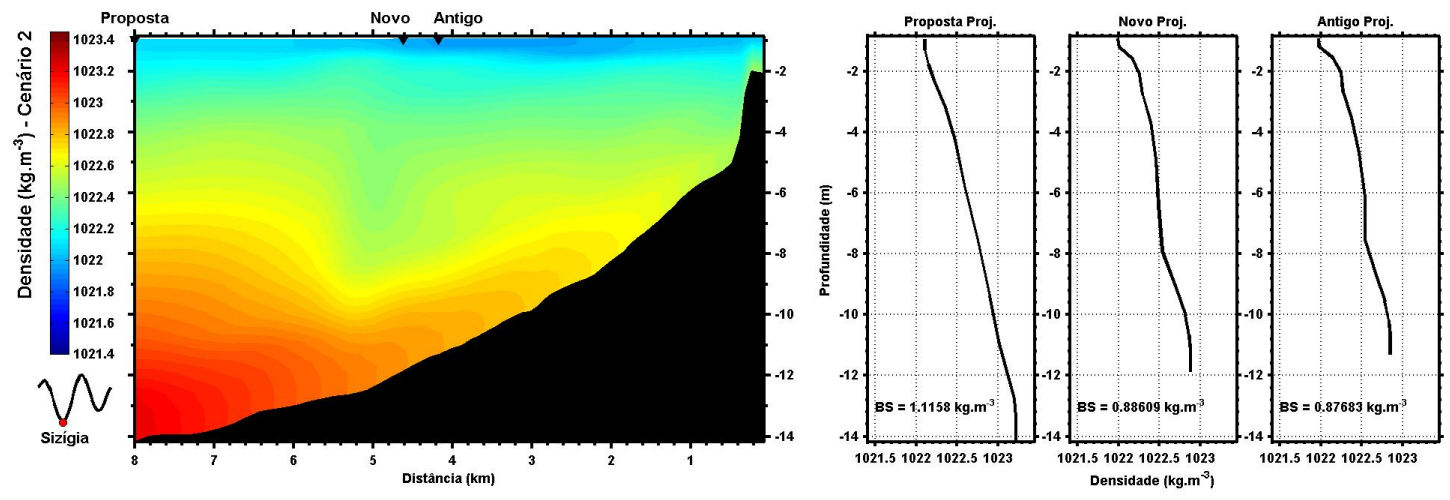

Figura 3.24: No painel da esquerda, seção vertical de densidade $\left(\mathrm{kg} . \mathrm{m}^{-3}\right)$ ao longo do emissário submarino de Santos para instante de baixamar de sizígia no cenário 2. No painel da direita estão representados os perfis vertical ao final do emissário submarino de Santos para os três projetos: antigo, novo e proposto. O valor de BS representa a estratificação bruta ("bulk stratification").

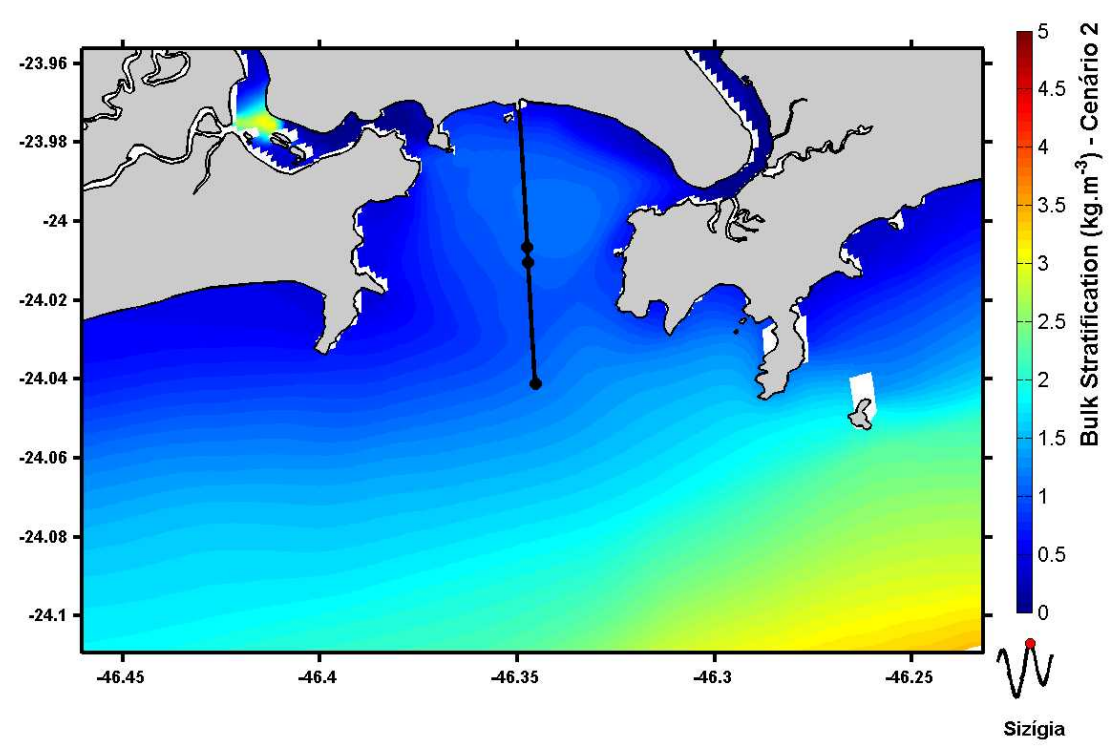

Figura 3.25: Campo de estratificação bruta ("bulk stratification") (kg.m ${ }^{-3}$ ) para instante de preamar em período de sizígia para o cenário 2.

comparado ao cenário 1 . Os maiores valores modelados na desembocadura do CSV no cenário 1 não estão presentes no cenário 3 e toda a região da BS apresenta menores estratificações.

Os perfis verticais de densidade (Figura 3.27) evidenciam uma camada superficial bem misturada, com valores constantes da superfície até a profundidade de aproximadamente $6 \mathrm{~m}$. O projeto proposto apresenta maior aumento na densidade quando comparado aos projetos novo e antigo. Este maior aumento reflete-se nos valores de estratificação bruta. Para o projeto proposto, este valor é de $0,70 \mathrm{~kg} \cdot \mathrm{m}^{-3}$, no projeto novo de $0,43 \mathrm{~kg} \cdot \mathrm{m}^{-3}$ e no projeto antigo $0,40 \mathrm{~kg} \cdot \mathrm{m}^{-3}$. Estes valores são todos inferiores quando comparados ao mesmo instante do cenário 1 (Figura 3.19). 


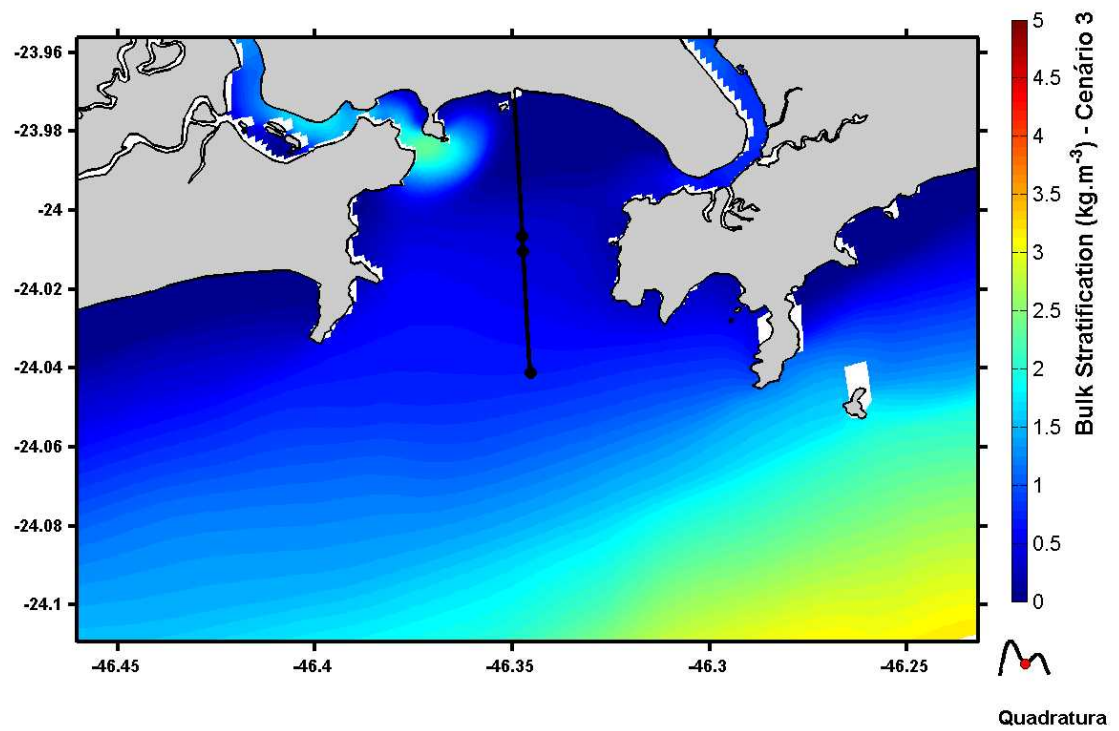

Figura 3.26: Campo de estratificação bruta ("bulk stratification") (kg.m ${ }^{-3}$ ) para instante de baixamar em período de quadratura para o cenário 3 .
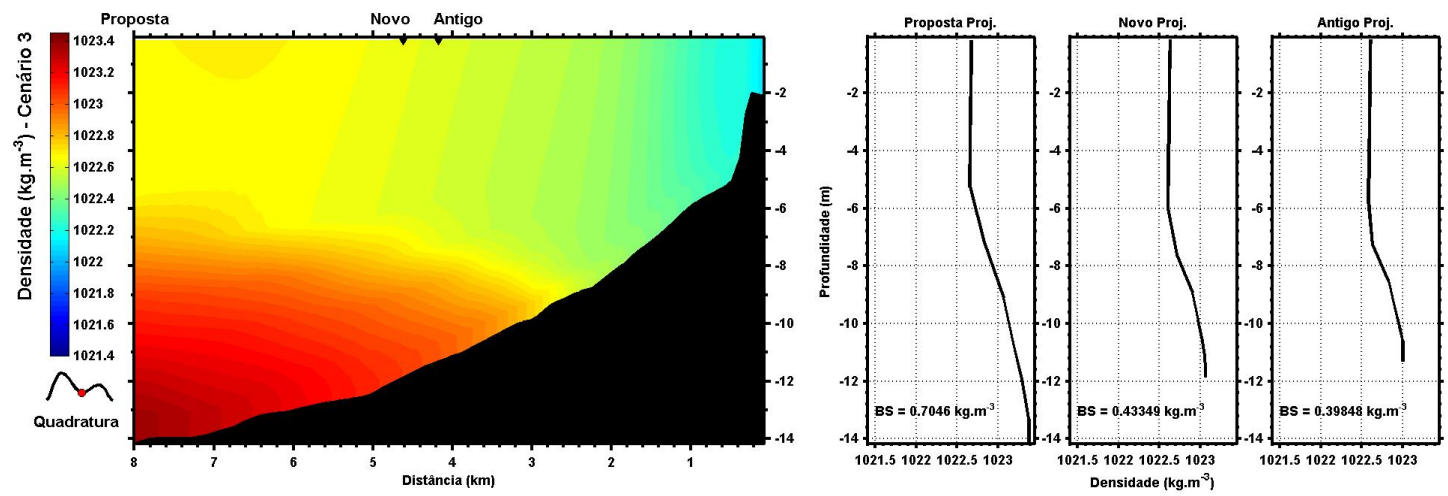

Figura 3.27: No painel da esquerda, seção vertical de densidade $\left(\mathrm{kg} \cdot \mathrm{m}^{-3}\right)$ ao longo do emissário submarino de Santos para instante de baixamar de quadratura no cenário 3. No painel da direita estão representados os perfis vertical ao final do emissário submarino de Santos para os três projetos: antigo, novo e proposto. O valor de BS representa a estratificação bruta ("bulk stratification").

O campo de estratificação bruta para o período de preamar de quadratura para o cenário 3 é similar ao da baixamar (Figura 3.26), apresentando as mesmas diferenças quando comparado ao cenário 1 (Figura 3.18). Os valores de estratificação bruta para o instante de preamar de quadratura são: $0,78 \mathrm{~kg} \cdot \mathrm{m}^{-3}, 0,49 \mathrm{~kg} \cdot \mathrm{m}^{-3}$ e 0,46 kg.m ${ }^{-3}$, para os projetos proposto, novo e antigo, respectivamente.

A estratificação bruta em baixamar de sizígia para o cenário 3 apresenta semelhança descritiva com os momentos de quadratura. Entretanto, os valores são inferiores quando comparados ao cenário 1, em toda a região da BS. No locais de lançamento de efluentes dos projetos antigo, novo e proposto, os valores de estratificação bruta são $0,71 \mathrm{~kg} \cdot \mathrm{m}^{-3}, 0,40 \mathrm{~kg} \cdot \mathrm{m}^{-3}$ e $0,38 \mathrm{~kg} \cdot \mathrm{m}^{-3}$, respectivamente (Figura 

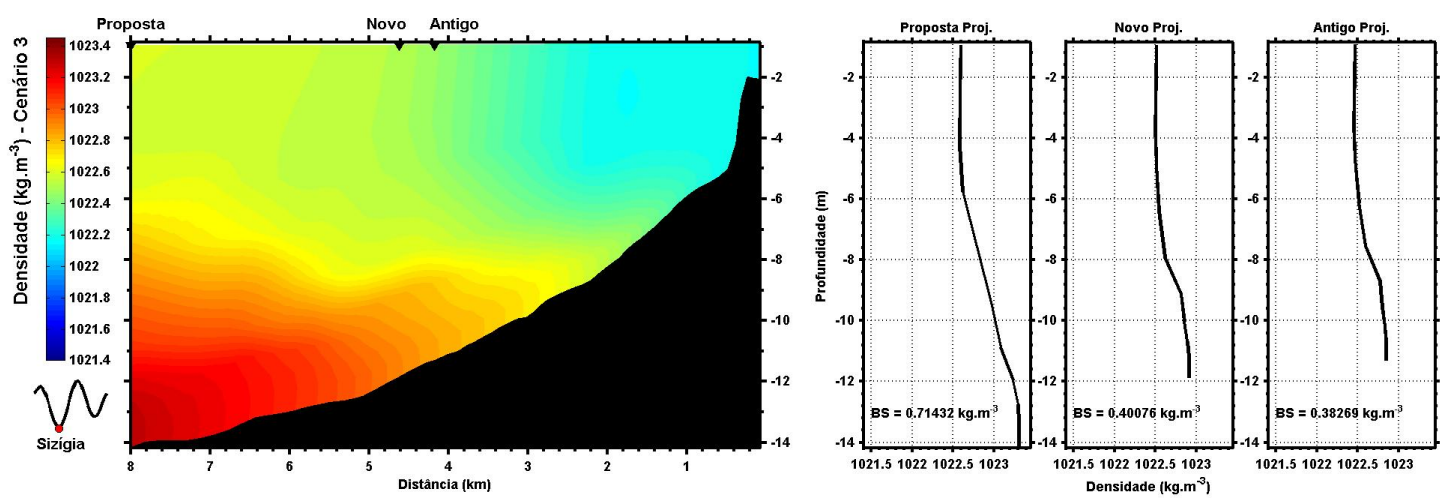

Figura 3.28: No painel da esquerda, seção vertical de densidade (kg. $\left.\mathrm{m}^{-3}\right)$ ao longo do emissário submarino de Santos para instante de baixamar de sizígia no cenário 3. No painel da direita estão representados os perfis vertical ao final do emissário submarino de Santos para os três projetos: antigo, novo e proposto. O valor de BS representa a estratificação bruta ("bulk stratification").

Conforme descrito para todos os instantes do cenário 3, a característica marcante deste quando comparado ao cenário 1 é o misturamento das águas na região da BS, promovendo diminuição nos valores modelados de estratificação bruta. No instante de preamar de sizígia do cenário 3, comparando com os valores de baixamar, em todos os projetos o valor da estratificação bruta é aumentado (Figura 3.29). Porém, quando comparado ao mesmo instante de tempo do cenário 1, estes valores apresentam menores magnitudes. No momento de preamar de sizígia para o cenário 3, os valores são de $0,75 \mathrm{~kg} \cdot \mathrm{m}^{-3}, 0,51 \mathrm{~kg} \cdot \mathrm{m}^{-3}$ e $0,51 \mathrm{~kg} \cdot \mathrm{m}^{-3}$, para os projetos proposto, novo e antigo, respectivamente.
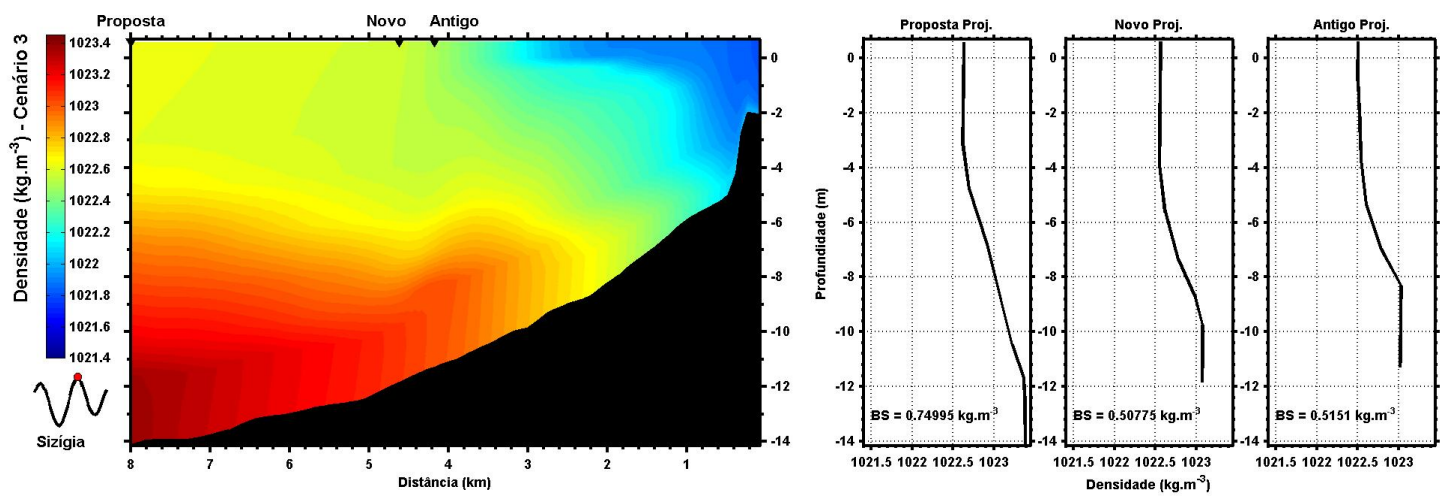

Figura 3.29: No painel da esquerda, seção vertical de densidade $\left(\mathrm{kg} . \mathrm{m}^{-3}\right)$ ao longo do emissário submarino de Santos para instante de preamar de sizígia no cenário 3. No painel da direita estão representados os perfis vertical ao final do emissário submarino de Santos para os três projetos: antigo, novo e proposto. O valor de BS representa a estratificação bruta ("bulk stratification"). 


\subsection{Modelagem do campo próximo}

Nesta seção serão apresentados os resultados referentes ao campo de diluição da pluma do ESS durante o campo próximo. Inicialmente, serão apresentadas as plumas dos três projetos em questão, em instantes de baixamar e preamar de sizígia e quadratura, para os cenários ambientais descritos na Seção 2.6 .

Para o cenário 1 em instante de baixamar de quadratura (Figura 3.30), as plumas modeladas apresentaram pequeno deslocamento lateral, tendo o final do campo próximo na superfície. Para o projeto antigo, ao final do campo próximo, a pluma apresentou diâmetro de aproximadamente $3,4 \mathrm{~m}$ e concentração de $0,30 \times 10^{5} \mathrm{ppm}$. Para o projeto novo, a pluma apresentou diâmetro de $3,6 \mathrm{~m}$ e concentração de $0,22 \mathrm{x}$ $10^{5}$ ppm. O projeto proposto apresentou $5,8 \mathrm{~m}$ de diâmetro, e $0,13 \times 10^{5}$ ppm para a concentração. Comparativamente, o projeto proposto apresentou um pequeno deslocamento da pluma em direção à plataforma continental (aproximadamente 1,0 m), a concentração ao final do campo próximo foi a menor e o diâmetro da pluma foi maior.

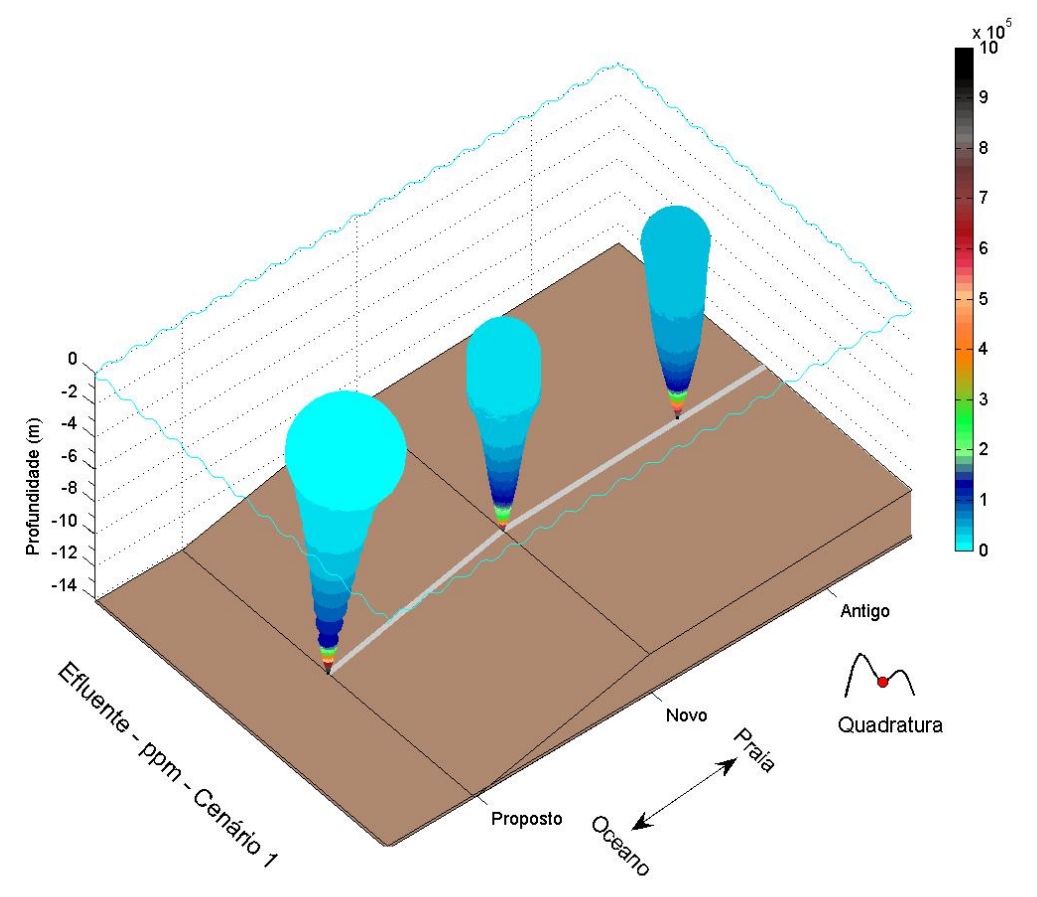

Figura 3.30: Representação tridimensional das plumas de efluentes no campo próximo do emissário de Santos para o momento de baixamar de quadratura, no cenário 1. Os três projetos são representados conjuntamente de forma comparativa. A pluma da esquerda refere-se ao Projeto Proposto, a pluma central ao Projeto Novo e a pluma da direita ao Projeto Antigo.

Para o cenário 1 em instante de preamar de quadratura (Figura 3.31) comparativamente ao instante de baixamar de quadratura, (Figura 3.30), os projetos antigo 
e novo, apresentaram os diâmetros (concentrações) das pluma modeladas ao final do campo próximo maiores (menores). Para o projeto proposto, a relação foi inversa. Ao final do campo próximo, em todos os projetos, as plumas estabilizaram-se somente na superfície. O diâmetro (concentração) modelado ao final do campo próximo para os projetos antigo, novo e proposto foram, respectivamente $5,2 \mathrm{~m}(0,26$ x $\left.10^{5} \mathrm{ppm}\right), 5,0 \mathrm{~m}\left(0,18 \times 10^{5} \mathrm{ppm}\right)$ e $5,5 \mathrm{~m}\left(0,14 \times 10^{5} \mathrm{ppm}\right)$. Como no instante de baixamar de quadratura (Figura 3.30), o projeto proposto apresentou pequeno deslocamento da pluma em direção à plataforma continental (aproximadamente 1 m), a concentração ao final do campo próximo foi a menor, e o maior diâmetro de pluma foi modelado.

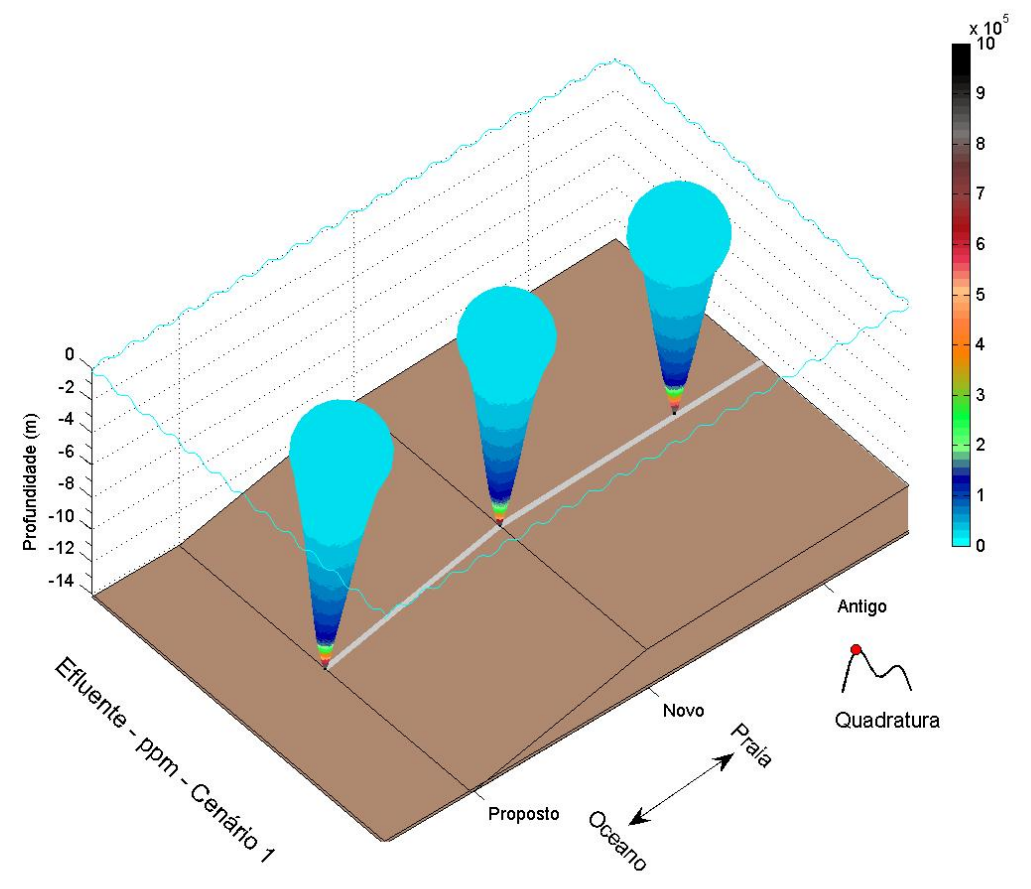

Figura 3.31: Representação tridimensional das plumas de efluentes no campo próximo do emissário de Santos para o momento de preamar de quadratura, no cenário 1. Os três projetos são representados conjuntamente de forma comparativa. A pluma da esquerda refere-se ao Projeto Proposto, a pluma central ao Projeto Novo e a pluma da direita ao Projeto Antigo.

A Figura 3.32 apresenta as plumas de efluentes no campo próximo para o cenário 1, em instante de baixamar de sizígia. Quando comparado ao instante de baixamar de quadratura (Figura 3.30), a maior diferença modelada para o instante de baixamar de sizígia é o deslocamento lateral das plumas de efluentes. Enquanto o deslocamento em momento de baixamar de quadratura é muito pequeno, em momento de baixamar de sizígia este torna-se mais significativo. Para o projeto antigo, o deslocamento foi de aproximadamente $1,8 \mathrm{~m}$ no sentido da praia, a pluma ao final do campo próximo apresentou diâmetro de 4,6 m, concentração de 0,21 x $10^{5}$ ppm. 
No projeto novo, o deslocamento modelado foi de $5,0 \mathrm{~m}$ em direção à praia, e o diâmetro (concentração) modelado da pluma ao final do campo próximo foi de 2,5 $\mathrm{m}\left(0,08 \times 10^{5} \mathrm{ppm}\right)$. Da mesma forma que nos instantes de baixamar e preamar de quadratura, em baixamar de sizígia, o projeto proposto apresentou o maior deslocamento, e o maior diâmetro, da pluma ao final do campo próximo. O deslocamento modelado foi de 2,5 m em direção nordeste (praia à leste), com diâmetro de 8,1 m e concentração de $0,14 \times 10^{5} \mathrm{ppm}$.

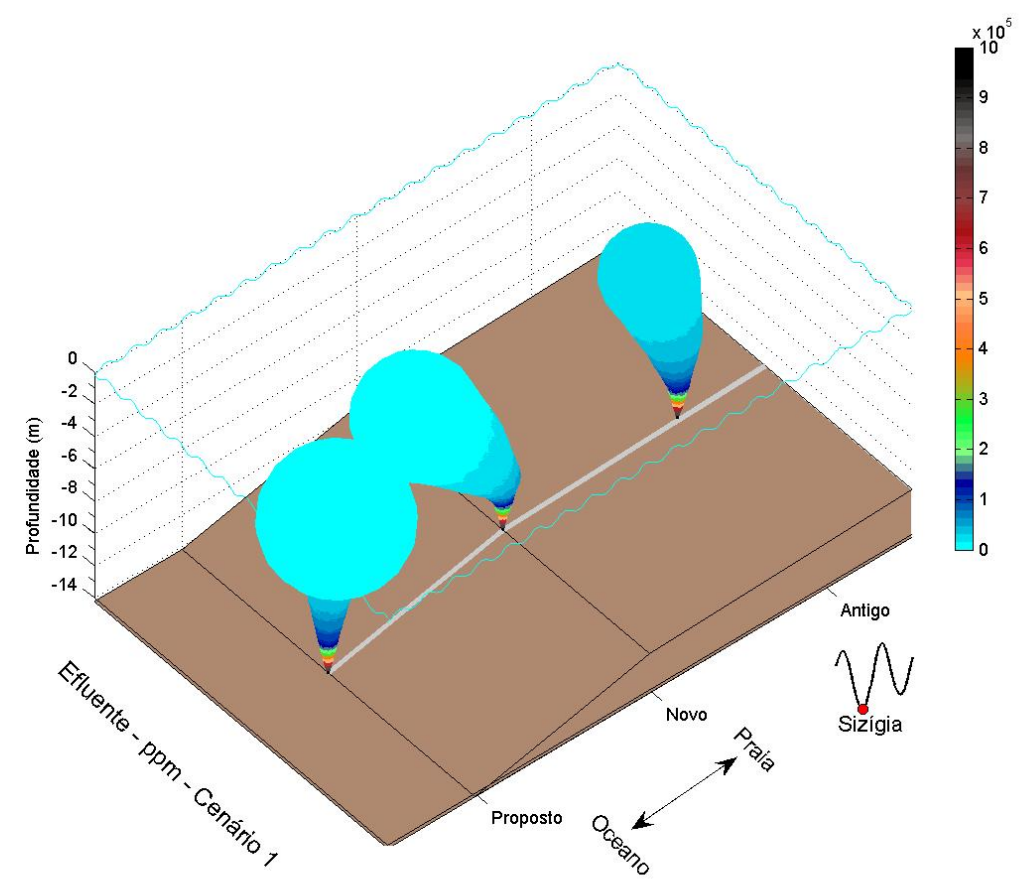

Figura 3.32: Representação tridimensional das plumas de efluentes no campo próximo do emissário de Santos para o momento de baixamar de sizígia, no cenário 1. Os três projetos são representados conjuntamente de forma comparativa. A pluma da esquerda refere-se ao Projeto Proposto, a pluma central ao Projeto Novo e a pluma da direita ao Projeto Antigo.

As plumas modeladas em instante de preamar de sizígia para o cenário 1, quando comparadas ao instante de baixamar de sizígia (Figura 3.32), apresentam menor deslocamento lateral, maior concentração, e menor diâmetro ao final do campo próximo. Porém, quando comparada ao mesmo instante de preamar, em quadratura (Figura 3.30), as plumas apresentam maiores deslocamentos, menores concentrações e maiores diâmetros. Em instantes de preamar de sizígia no cenário 1, foram modeladas ao final do campo próximo para os projetos antigo, novo e proposto, respectivamente: 1,6 m, 2,0 m e 2,4 m, para deslocamentos em direção à plataforma continental, 4,0 m, 4,6 m e 8,9 m para o diâmetro e $0,26 \times 10^{5} \mathrm{ppm}, 0,17 \times 10^{5} \mathrm{ppm}$ e $0,11 \times 10^{5}$ ppm para a concentração.

Ao comparar o instante de baixamar de quadratura do cenário 2 com o mesmo 
instante para o cenário 1 (Figura 3.30), observa-se grande similaridade entre estes, principalmente nas características de deslocamento lateral e diâmetro da pluma. As maiores diferenças foram modeladas nas concentrações ao final do campo próximo. No instante de baixamar de quadratura do cenário 2, as concentrações modeladas ao final do campo próximo para os projetos antigo, novo e proposto são $0,30 \times 10^{5}$ ppm, $0,25 \times 10^{5}$ ppm e $0,19 \times 10^{5}$ ppm, respectivamente.

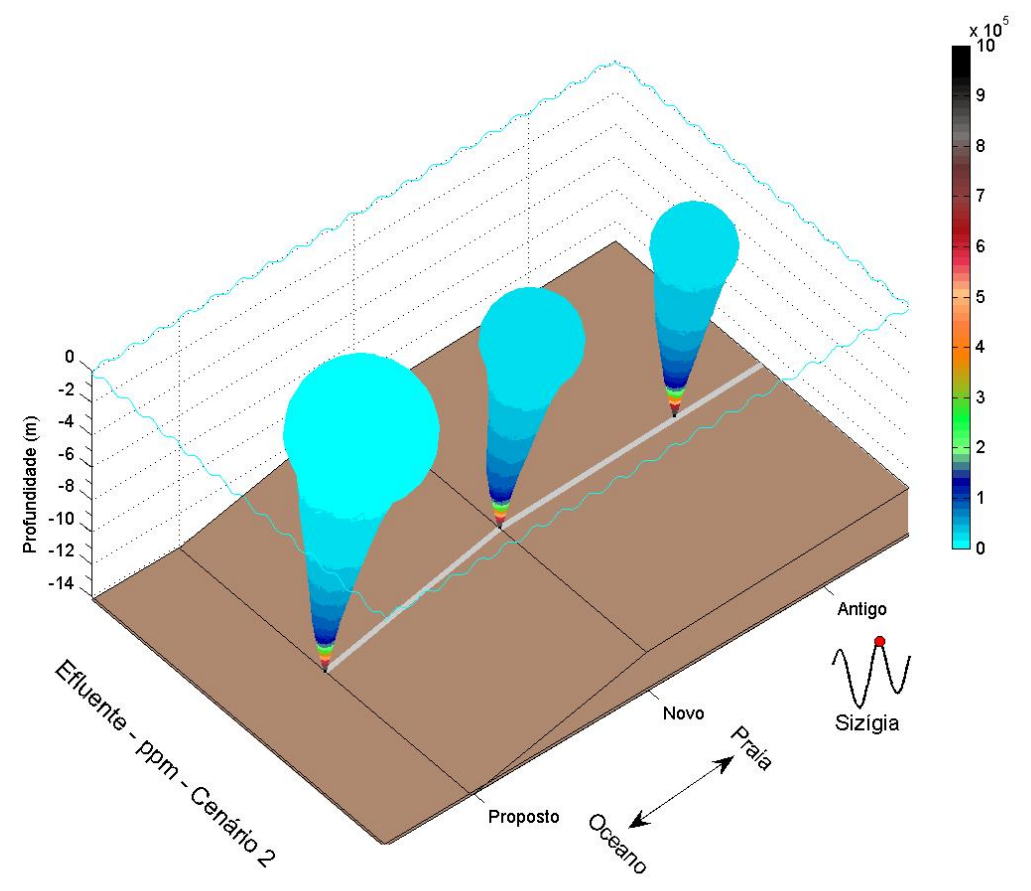

Figura 3.33: Representação tridimensional das plumas de efluentes no campo próximo do emissário de Santos para o momento de preamar de sizígia, no cenário 2. Os três projetos são representados conjuntamente de forma comparativa. A pluma da esquerda refere-se ao Projeto Proposto, a pluma central ao Projeto Novo, e a pluma da direita ao Projeto Antigo.

Da mesma maneira que o modelado para o cenário 1, quando comparados os instantes de baixamar de quadratura e de preamar de quadratura, observa-se que os deslocamentos laterais e os diâmetros modelados ao final do campo próximo são superiores na preamar, enquanto que as concentrações são inferiores. No cenário 2, para os projetos antigo, novo e proposto, respectivamente, os valores dos diâmetros das plumas ao final do campo próximo modelados foram: 5,4 m, 5,4 m e 6,1 m. Para a concentração, os resultados modelados foram $0,28 \times 10^{5} \mathrm{ppm}, 0,19 \times 10^{5} \mathrm{ppm}$ e $0,19 \times 10^{5} \mathrm{ppm}$, respectivamente.

Quando comparados os cenário 1 (Figura 3.32 e 2 , praticamente as mesmas características das plumas foram modeladas na baixamar de sizígia. O deslocamento lateral das plumas para os projetos antigo, novo e proposto foram de $1,8 \mathrm{~m} \mathrm{em}$ direção à praia, 4,6 m em direção à praia e 2,9 m em direção nordeste. Os diâmetros 
modelados foram 4,8 m, 7,0 m e 8,1 m respectivamente. As concentrações modeladas ao final do campo próximo foram de $0,21 \times 10^{5} \mathrm{ppm}, 0,09 \times 10^{5} \mathrm{ppm}$ e $0,11 \times 10^{5}$ ppm, respectivamente.

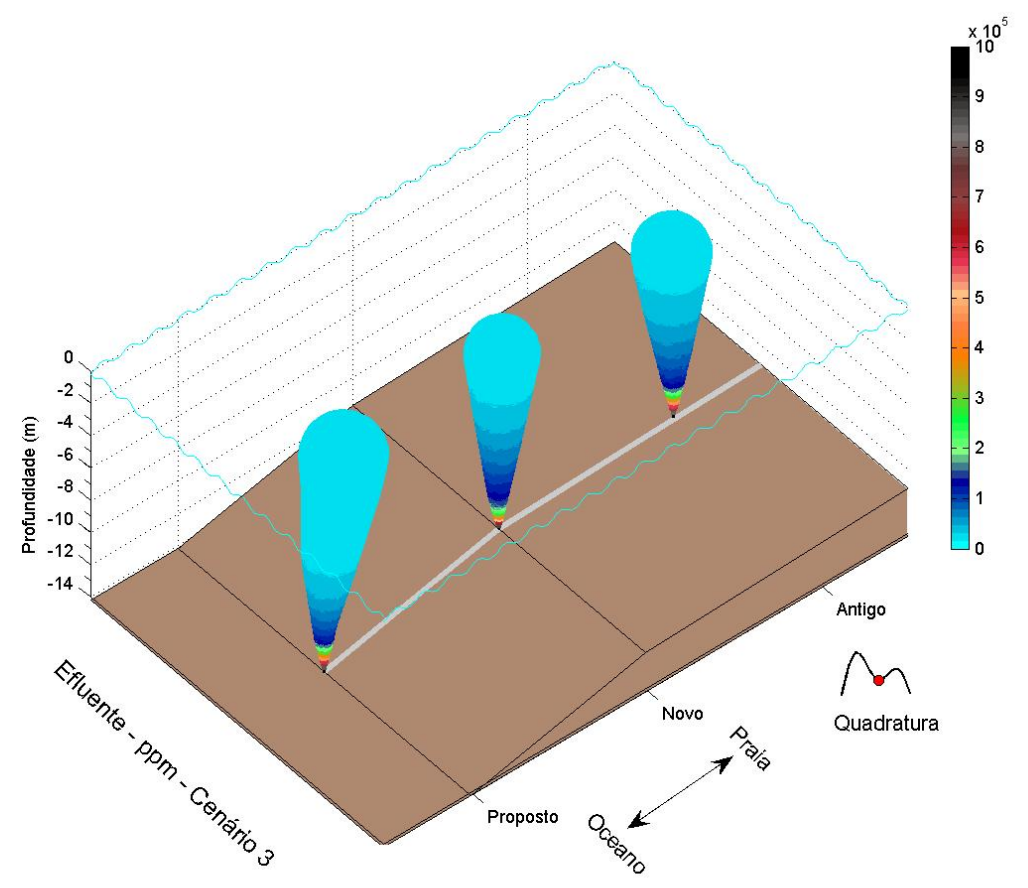

Figura 3.34: Representação tridimensional das plumas de efluentes no campo próximo do emissário de Santos para o momento de baixamar de quadratura, no cenário 3. Os três projetos são representados conjuntamente de forma comparativa. A pluma da esquerda refere-se ao Projeto Proposto, a pluma central ao Projeto Novo e a pluma da direita ao Projeto Antigo.

A Figura 3.33 apresenta as plumas de efluentes no campo próximo para o cenário 2, em instante de preamar de sizígia. Quando comparados os instantes de baixamar e de preamar de sizígia, neste último houve menor deslocamento lateral, maiores concentrações e menor diâmetro da pluma ao final do campo próximo. Já quando comparados os cenários 1 e 2, as maiores diferenças modeladas estão no deslocamento lateral da pluma e no diâmetro desta ao final do campo próximo. No instante de preamar de sizígia para o cenário 2, o deslocamento lateral da pluma para os projetos antigo, novo e proposto é de $0,6 \mathrm{~m}, 1,0 \mathrm{~m}$ e $2,7 \mathrm{~m}$, em direção à plataforma continental, respectivamente. O diâmetro das plumas é de 5,1 m, 5,7 m e 8,0 m, respectivamente. Os valores de concentração modelados ao final do campo próximo são de $0,20 \times 10^{5} \mathrm{ppm}, 0,14 \times 10^{5} \mathrm{ppm}$ e $0,11 \times 10^{5} \mathrm{ppm}$, respectivamente.

Quando comparado o instante de baixamar de quadratura entre o cenário 1 (Figura 3.30) e o cenário 3 (Figura 3.34), a diferença marcante modelada é o menor diâmetro da pluma ao final do campo próximo para o projeto proposto neste último cenário. O diâmetro de 5,8 m no cenário 1, é reduzido para 3,9 m no cenário 3 . 


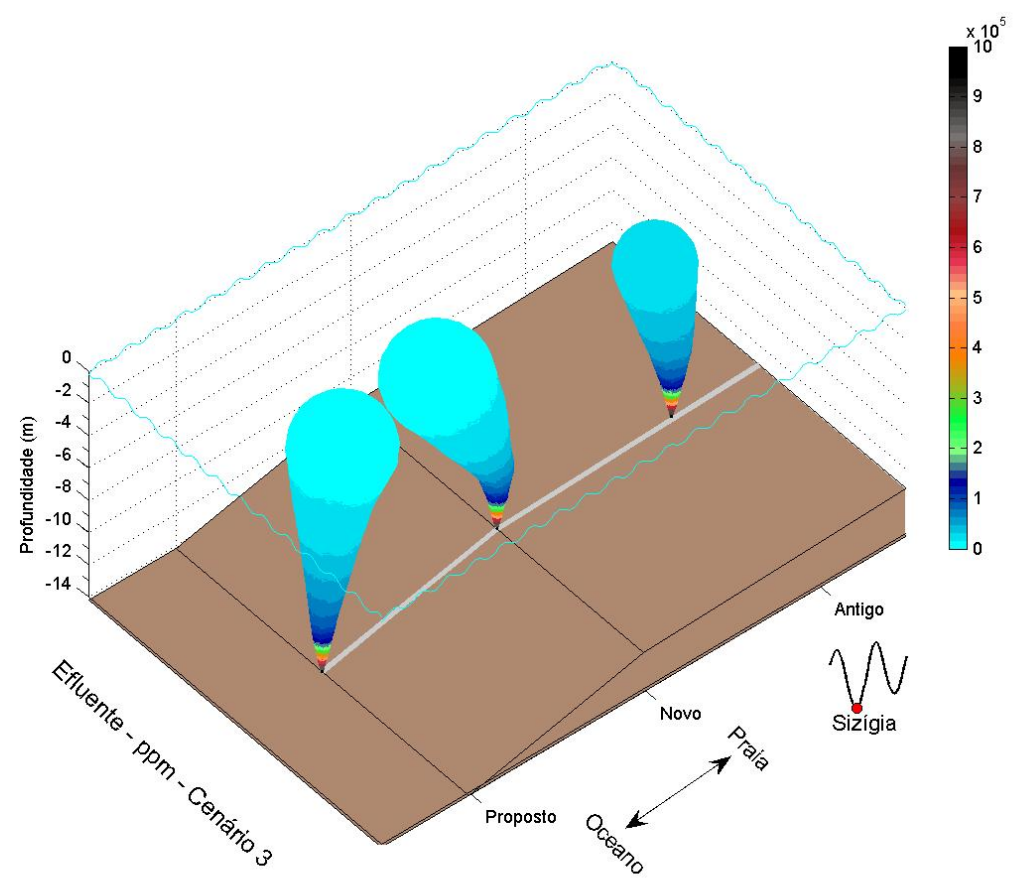

Figura 3.35: Representação em profundidade das plumas de efluentes no campo próximo do emissário de Santos para o momento de baixamar de sizígia, no cenário 3. Os três projetos são representados conjuntamente de forma comparativa. A pluma da esquerda refere-se ao Projeto Proposto, a pluma central ao Projeto Novo, e a pluma da direita ao Projeto Antigo.

Da mesma forma que os cenários 1 e 2, quando comparados os instantes de preamar e baixamar de quadratura, poucas alterações são observadas. Porém, quando comparado os resultados para os cenários 1 e 3, modelou-se um aumento no deslocamento lateral da pluma, diminuição do diâmetro (projetos antigo e novo) e diminuição da concentração (projetos antigo e proposto). Para o cenário 3, em instante de preamar de quadratura, o deslocamento lateral para os projetos antigo, novo e proposto foi de $0,4 \mathrm{~m}, 0,7 \mathrm{~m}$ e 1,2 m em direção à plataforma continental, respectivamente. Para o diâmetro, os valores modelados foram de 4,4 m, 3,6 m e 8,0 m, respectivamente. As concentrações ao final do campo próximo foram de 0,23 x $10^{5}$ ppm, $0,20 \times 10^{5}$ ppm e $0,12 \times 10^{5}$ ppm, respectivamente.

A Figura 3.35 apresenta as plumas de efluentes no campo próximo para o cenário 3, em instante de baixamar de sizígia. Diferentemente do verificado nos cenários 1 e 2, as maiores diferenças modeladas para o instante de baixamar de sizígia comparativamente à baixamar de quadratura são o deslocamento lateral e o diâmetro das plumas. No cenário 3, o deslocamento lateral da pluma para os projetos antigo, novo e proposto é de $0,9 \mathrm{~m}, 3,0 \mathrm{~m}$ e 1,9 m em direção à praia. O diâmetros da plumas modeladas no final do campo próximo é de 4,2 m, 5,7 e 5,9 m para os projetos antigo, novo e proposto, respectivamente. As concentrações de 0,22 x $10^{5} \mathrm{ppm}, 0,12$ 


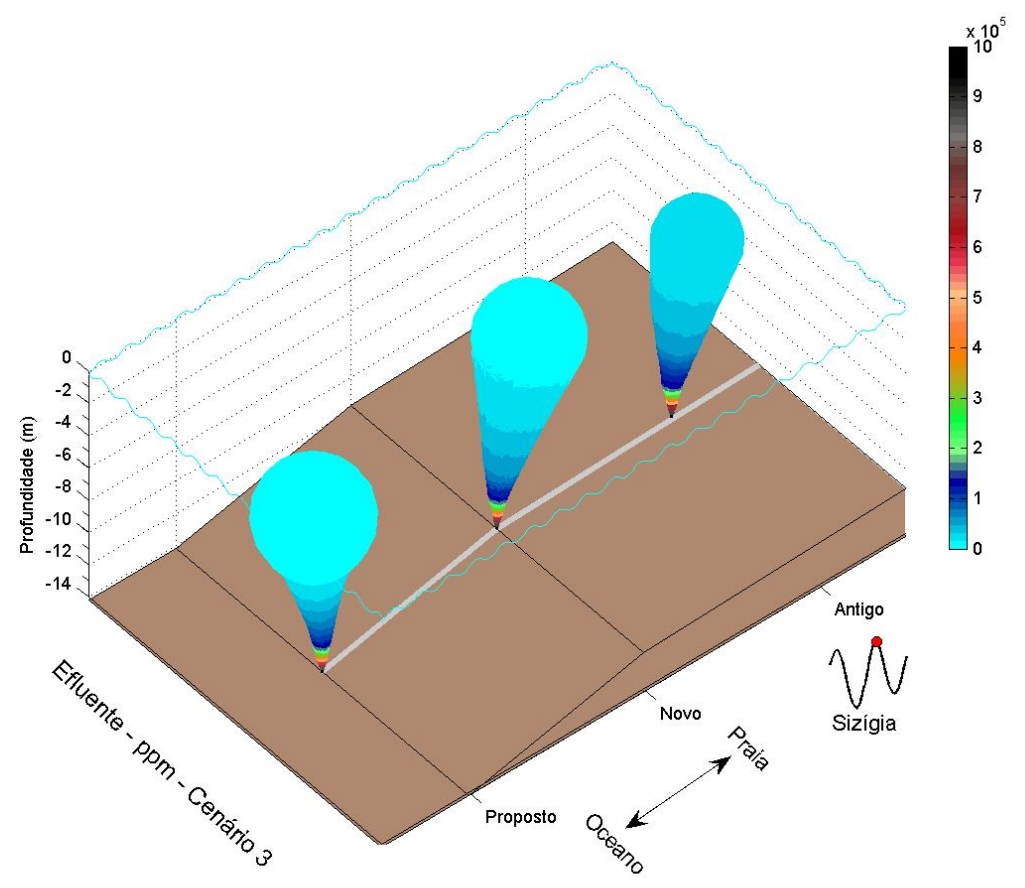

Figura 3.36: Representação em profundidade das plumas de efluentes no campo próximo do emissário de Santos para o momento de preamar de sizígia, no cenário 3. Os três projetos são representados conjuntamente de forma comparativa. A pluma da esquerda refere-se ao Projeto Proposto, a pluma central ao Projeto Novo, e a pluma da direita ao Projeto Antigo.

x $10^{5}$ ppm e 0,11 x $10^{5}$ ppm são representativas do final do campo próximo para os projetos antigo, novo e proposto, respectivamente.

Quando comparados os instantes de baixamar e preamar de sizígia no cenário 3 (Figuras 3.35 e 3.36), verifica-se que as maiores diferenças são modeladas nos deslocamentos laterais das plumas. Já quando comparados os cenários 1 e 3 (Figura 3.36), grande similaridade é observada, exceto pelo sentido de deslocamento da pluma do projeto proposto. Para o instante de preamar de sizígia no cenário 3, o deslocamento das plumas foi de 1,9 m sentido do oceano, 2,9 $\mathrm{m}$ sentido do oceano e 3,0 sentido noroeste para os projetos antigo, novo e proposto, respectivamente. $\mathrm{O}$ diâmetro das plumas, para estes mesmos projetos, é de 4,60 m, 5,70 m e 6,00 m, respectivamente. Já a concentração modelada ao final do campo próximo para estes projetos foi de $0,20 \times 10^{5} \mathrm{ppm}, 0,12 \times 10^{5} \mathrm{ppm}$ e $0,10 \times 10^{5} \mathrm{ppm}$, respectivamente. 


\subsection{Modelagem do campo distante}

Nesta seção serão apresentados os resultados da dispersão dos efluentes do ESS no campo distante. Os resultados serão apresentados para os ciclos de enchente-vazante em períodos de maré de sizígia e quadratura para os 3 cenários ambientais propostos. Os resultados serão expressos em porcentagem do tempo do ciclo de enchente-vazante que as águas da região modelada apresentaram concentrações acima de 1000 ppm, 500 ppm, 250 ppm e 125 ppm.
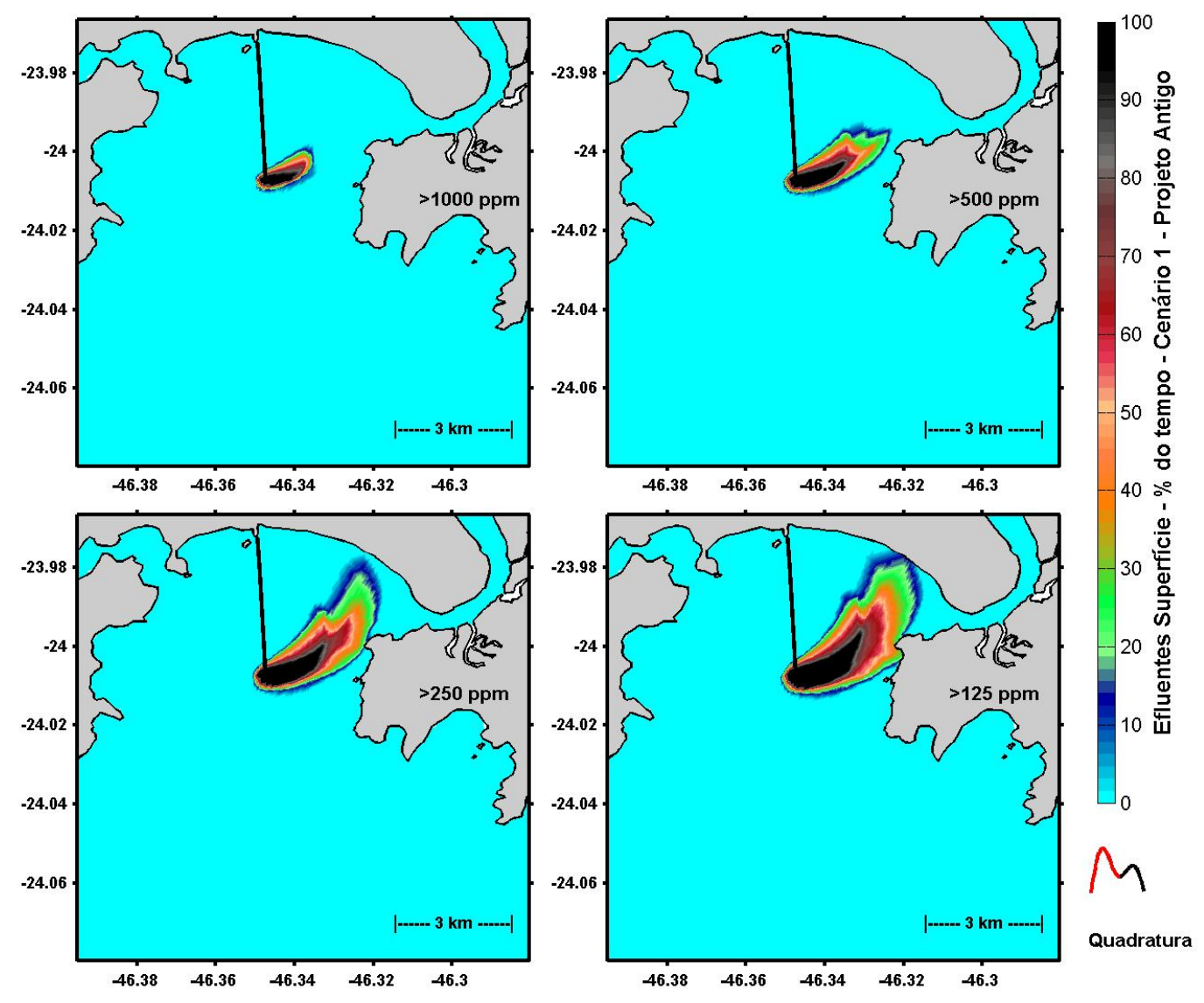

Figura 3.37: Frequência de ocorrência de concentração de efluente, em superfície, lançado pelo projeto antigo, para o período de enchente-vazante em quadratura, no cenário 1.

O lançamento do projeto antigo em período quadratura no cenário 1 (Figura 3.37 gerou uma pluma de concentração superior a 1000 ppm com extensão máxima aproximada de 1,6 km, na direção nordeste (sentido praia), em superfície. A parte da pluma que esteve $100 \%$ do tempo com concentração acima de 1000 ppm apresentou extensão de $0,8 \mathrm{~km}$, na direção nordeste/leste. Avaliando-se concentrações superiores a 500 ppm, a extensão máxima modelada em superfície foi de 3,0 km. Para a pluma que esteve $100 \%$ do tempo acima desta concentração, a extensão modelada foi de $1,3 \mathrm{~km}$. Concentração superior a $250 \mathrm{ppm}$ apresentou extensão máxima de $4,4 \mathrm{~km}$ atingindo a praia de Santos em aproximadamente $2 \%$ do tempo. Esta pluma 
também atinge a porção mais à oeste da Ilha de Santo Amaro (Guarujá) em aproximadamente $25 \%$ do tempo. Para a pluma que esteve $100 \%$ do tempo acima desta concentração, a extensão modelada foi de 1,9 km em superfície na direção nordeste (sentido praia). Concentração superior a 125 ppm apresentou extensão máxima de 4,4 km em superfície. Esta concentração atinge a praia de Santos em aproximadamente $15 \%$ do tempo e a porção mais à oeste da Ilha de Santo Amaro (Guarujá) em aproximadamente $40 \%$ do tempo. Para a pluma que esteve $100 \%$ do tempo acima desta concentração, a extensão modelada foi de $2,2 \mathrm{~km}$ na direção nordeste (sentido praia).
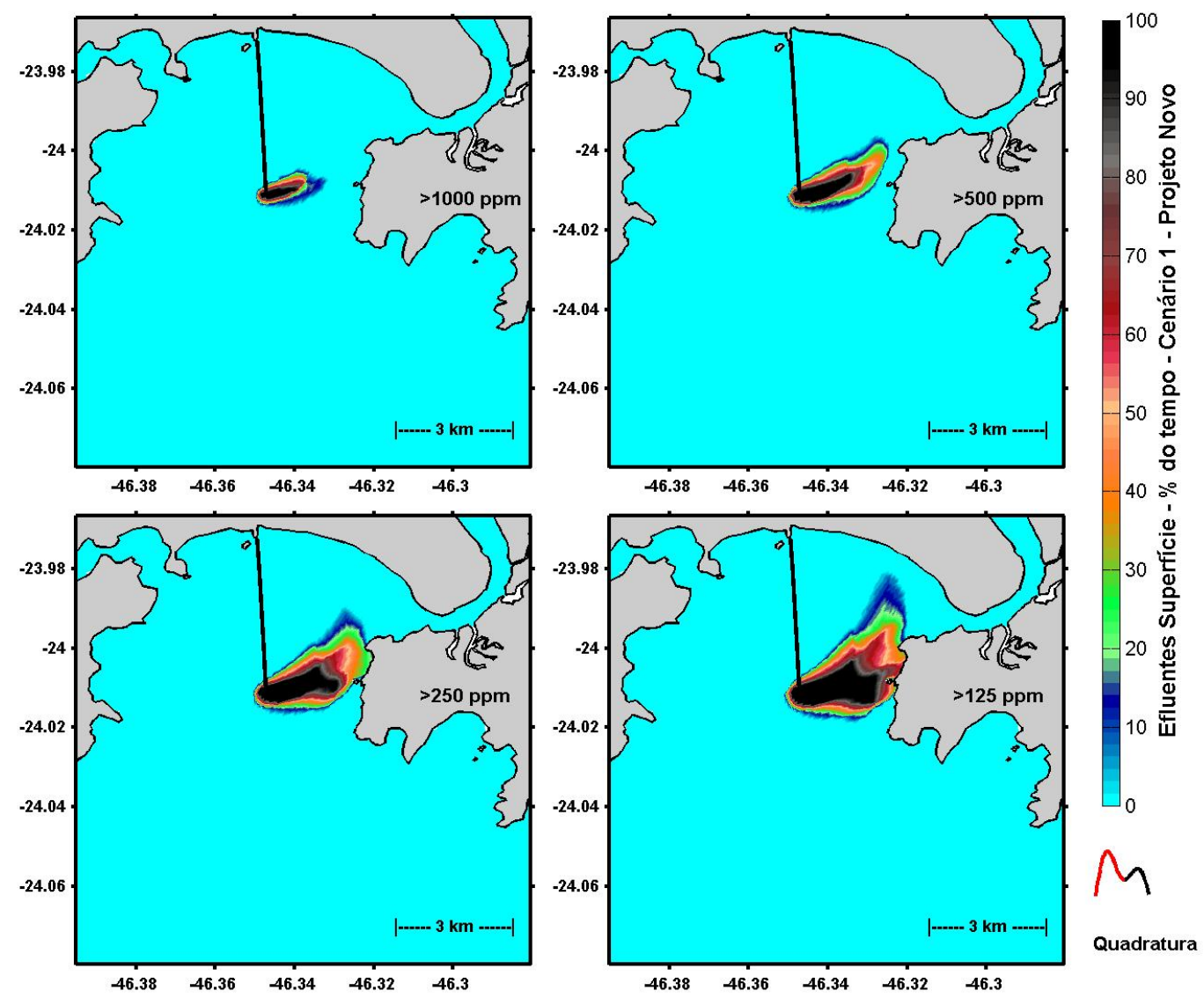

Figura 3.38: Frequência de ocorrência de concentração de efluente, em superfície, lançado pelo projeto novo, para o período de enchente-vazante em quadratura, no cenário 1.

Comparando as concentrações modeladas pelo projeto novo (Figura 3.38 em período de quadratura no cenário 1, com aquela do projeto antigo (Figura 3.37), verifica-se que a pluma está deslocada para o exterior da BS, embora tenha características similares. Este deslocamento faz com que a costa oeste do Guarujá seja atingida por maiores concentrações dos efluentes com maior frequência. No projeto novo, a pluma com concentração superior a 250 ppm atinge a costa oeste do Guarujá em aproximadamente $25 \%$ do tempo. Concentração superior a $125 \mathrm{ppm}$ atinge a 
costa oeste do Guarujá em aproximadamente $60 \%$ do tempo. Em superfície, essa pluma atinge a costa oeste do Guarujá em aproximadamente 80\% do tempo.

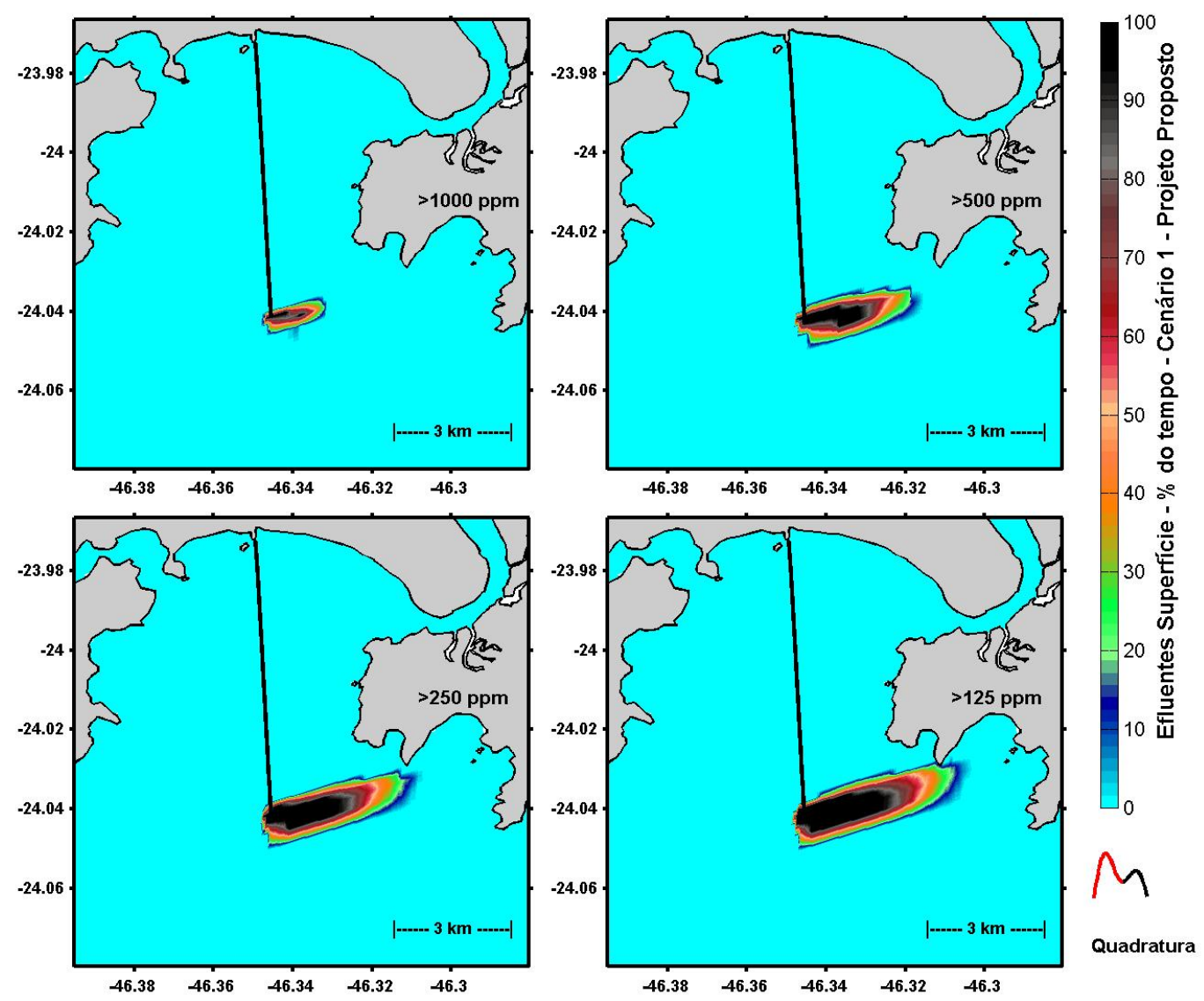

Figura 3.39: Frequência de ocorrência de concentração de efluente, em superfície, lançado pelo projeto proposto, para o período de enchente-vazante em quadratura, no cenário 1.

Comparando as plumas modeladas pelos projetos antigo e proposto (Figuras 3.37 e 3.39, verifica-se neste último maior extensão com menor frequência, e menor extensão com maior frequência, embora os efluentes ocupem quase unicamente a superfície. Por estar fora da BS, a pluma intercepta a costa a uma pequena distância na porção sul do Guarujá em 8\% do tempo, com concentração acima de 125 ppm. Concentração superior a 1000 ppm apresenta extensão máxima de $1,5 \mathrm{~km}$, na direção leste. A pluma que esteve $100 \%$ do tempo com concentração acima de 1000 ppm apresentou extensão de $0,5 \mathrm{~km}$, na mesma direção. Concentração superior a 500 ppm, apresentou extensão máxima de $3,0 \mathrm{~km}$, em direção leste. Para a pluma que esteve $100 \%$ do tempo acima desta concentração, sua extensão foi de $1,5 \mathrm{~km}$. Concentração superior a 250 ppm, apresentou extensão máxima de 4,0 km. Para a pluma que esteve $100 \%$ do tempo acima desta concentração, a extensão modelada foi de 2,0 km na direção leste (sentido Guarujá).

Comparando os resultados obtidos para os projetos em período de quadratura 
(Figuras 3.37, 3.38 e 3.39), no cenário 1, com o período de sizígia (Figuras 3.40, 3.41 e 3.42), nestes últimos as plumas encontram-se mais diluídas (menores extensões para o mesmo intervalo de concentração) e o sentido de deslocamento é voltado preferencialmente para a região adjacente à BS.
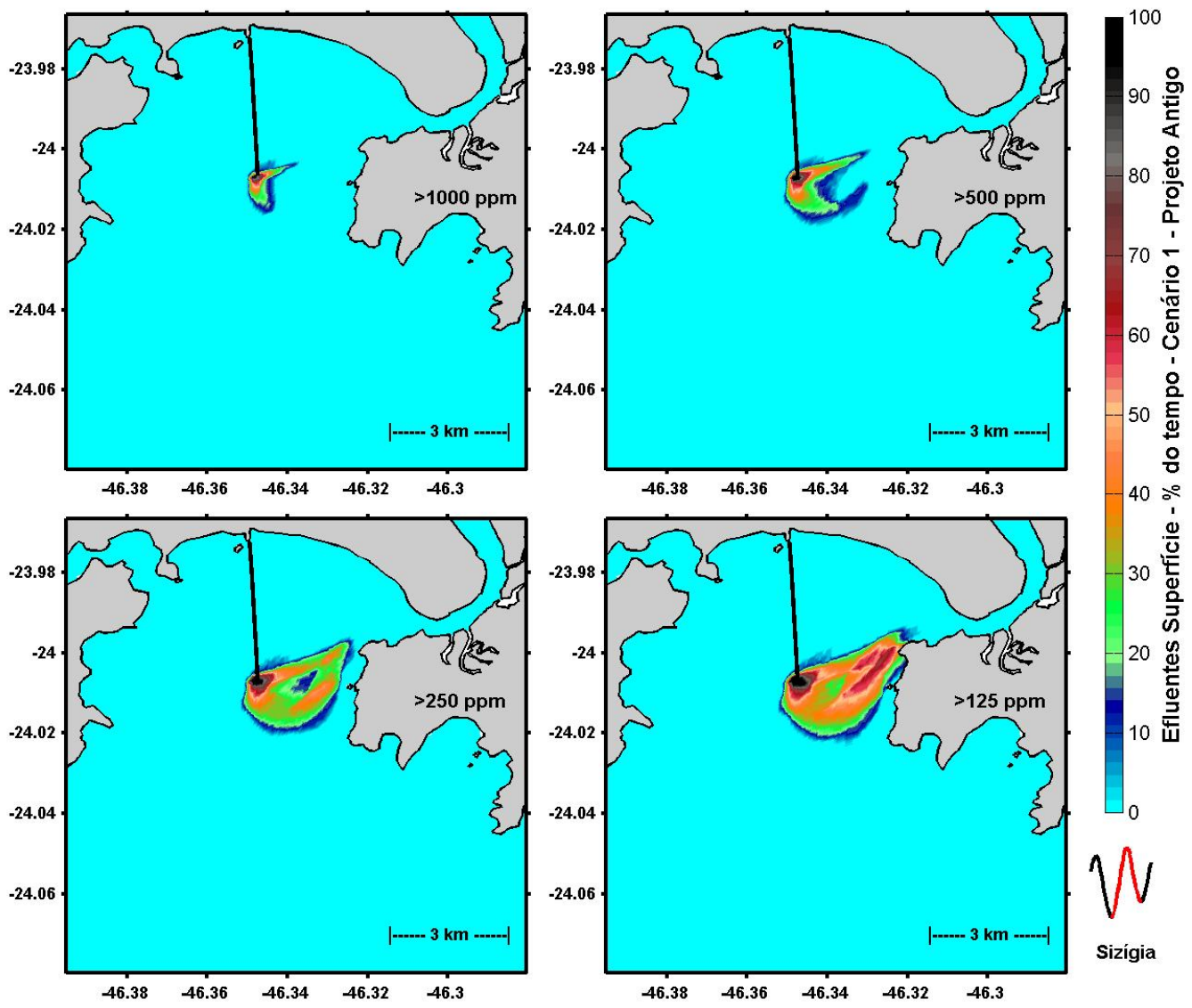

Figura 3.40: Frequência de ocorrência de concentração de efluente, em superfície, lançado pelo projeto antigo, para o período de enchente-vazante em sizígia, no cenário 1.

Para o projeto antigo, em período de sizígia no cenário 1 (Figura 3.40 foi modelada concentração superior a 1000 ppm com extensão máxima de 1,0 km, na direção sul, e 1,0 km na direção leste. A pluma que esteve $100 \%$ do tempo com concentração acima de 1000 ppm apresentou extensão de 0,1 km em superfície, ao redor do local de lançamento de efluentes. Concentração superior a 500 ppm, apresentou uma extensão máxima de 1,0 km, na direção sul, e de 2,0 km, na direção nordesteleste, sentido Guarujá na superfície. Para a pluma que esteve 100\% do tempo acima desta concentração, a extensão modelada é de $0,2 \mathrm{~km}$ em superfície ao redor do local de lançamento de efluentes. Concentração superior a 250 ppm, apresentou extensão máxima de 2,0 km em superfície, em direção leste. Para a pluma que esteve $100 \%$ do tempo acima desta concentração, a extensão modelada foi de $0,25 \mathrm{~km}$. Concentração superior a 125 ppm apresentou extensão máxima de 3,0 km em superfície. Esta 
pluma atinge a porção oeste do Guarujá em aproximadamente 50\% do tempo. Para a pluma que esteve $100 \%$ do tempo acima desta concentração, a extensão modelada foi de $0,3 \mathrm{~km}$ ao redor do local de lançamento de efluentes.

Comparando-se os projetos novo e antigo (Figuras 3.41 e 3.40, no primeiro a pluma apresenta-se mais diluída (menores extensões para o mesmo intervalo de concentração) e deslocada para fora da BS.

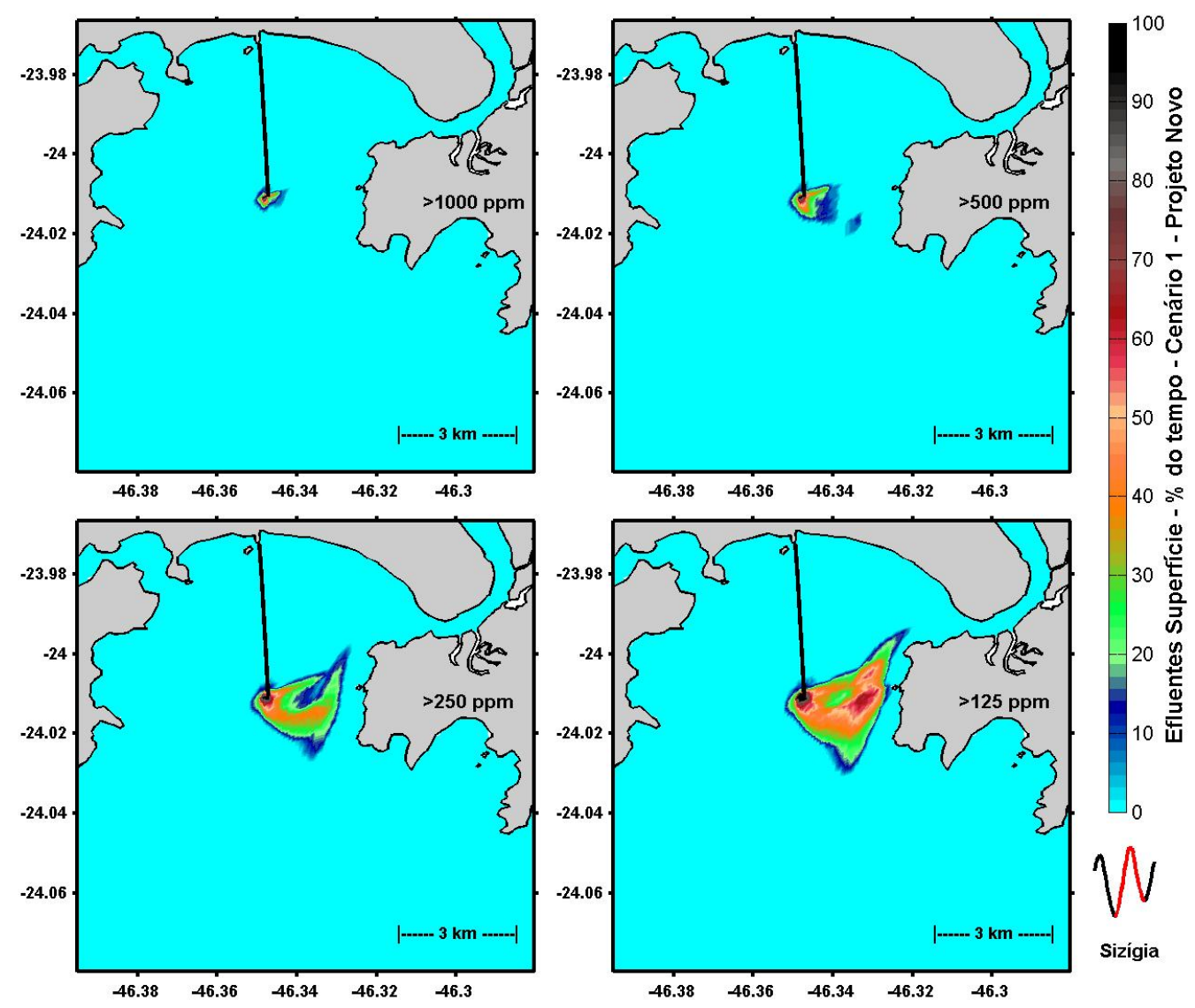

Figura 3.41: Frequência de ocorrência de concentração de efluente, em superfície, lançado pelo projeto novo, para o período de enchente-vazante em sizígia, no cenário 1.

O projeto proposto (Figura 3.42 quando comparando com o projeto antigo (Figura 3.40), apresentou plumas de maior extensão com menor frequência e de menor extensão com maior frequência, sempre em superfície. Concentração superior a 1000 ppm apresentou extensão máxima de $0,4 \mathrm{~km}$, ao redor do local de lançamento de efluentes. A máxima porcentagem de tempo modelada é de $50 \%$, para extensão de $0,1 \mathrm{~km}$ ao redor do local de lançamento de efluentes. Concentração superior a 500 ppm apresentou extensão máxima de 1,2 km para qualquer instante de tempo, em direção nordeste, e 0,80 km em direção sul. Para a pluma que esteve $100 \%$ do tempo acima desta concentração, sua extensão modelada foi de $0,1 \mathrm{~km}$ ao redor do local de lançamento de efluentes. Concentração superior a $250 \mathrm{ppm}$ foi modelada com 


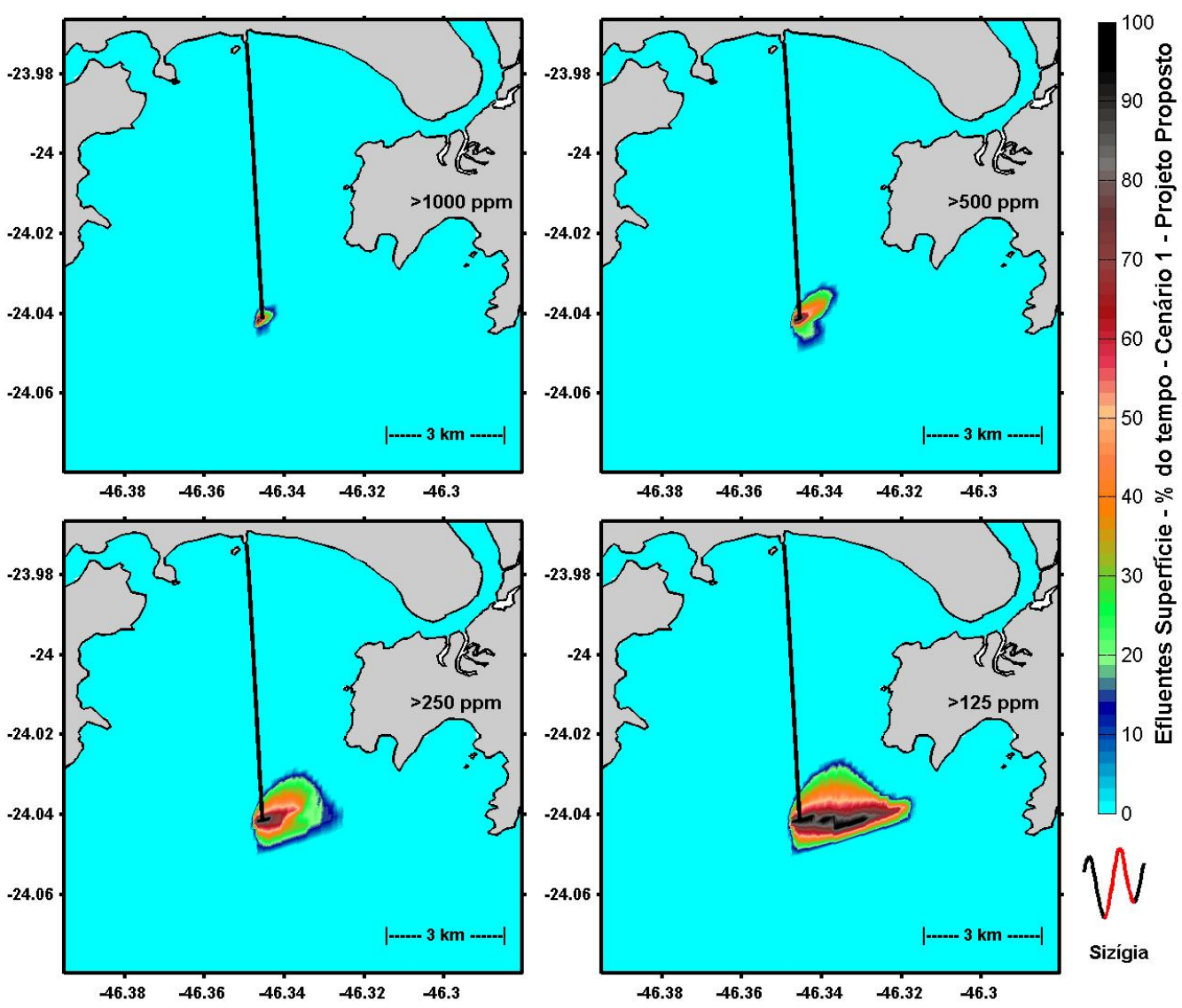

Figura 3.42: Frequência de ocorrência de concentração de efluente, em superfície, lançado pelo projeto proposto, para o período de enchente-vazante em sizígia, no cenário 1.

extensão máxima de 2,0 km, em direção leste, e 2,0 km sentido nordeste. Para a pluma que esteve $100 \%$ do tempo acima desta concentração, a extensão modelada foi $0,02 \mathrm{~km}$ na direção leste-oeste. Concentração superior a $125 \mathrm{ppm}$ foi modelada com extensão máxima de $3,0 \mathrm{~km}$, em direção leste. Para a pluma que esteve $100 \%$ do tempo acima desta concentração, a extensão modelada foi de 1,8 km na direção leste. 
As Figuras 3.43, 3.44 e 3.45 apresentam a frequência de ocorrência de concentração de efluente em superfície para o período de enchente-vazante em quadratura, no cenário 2, para os projetos antigo, novo e proposto, respectivamente.

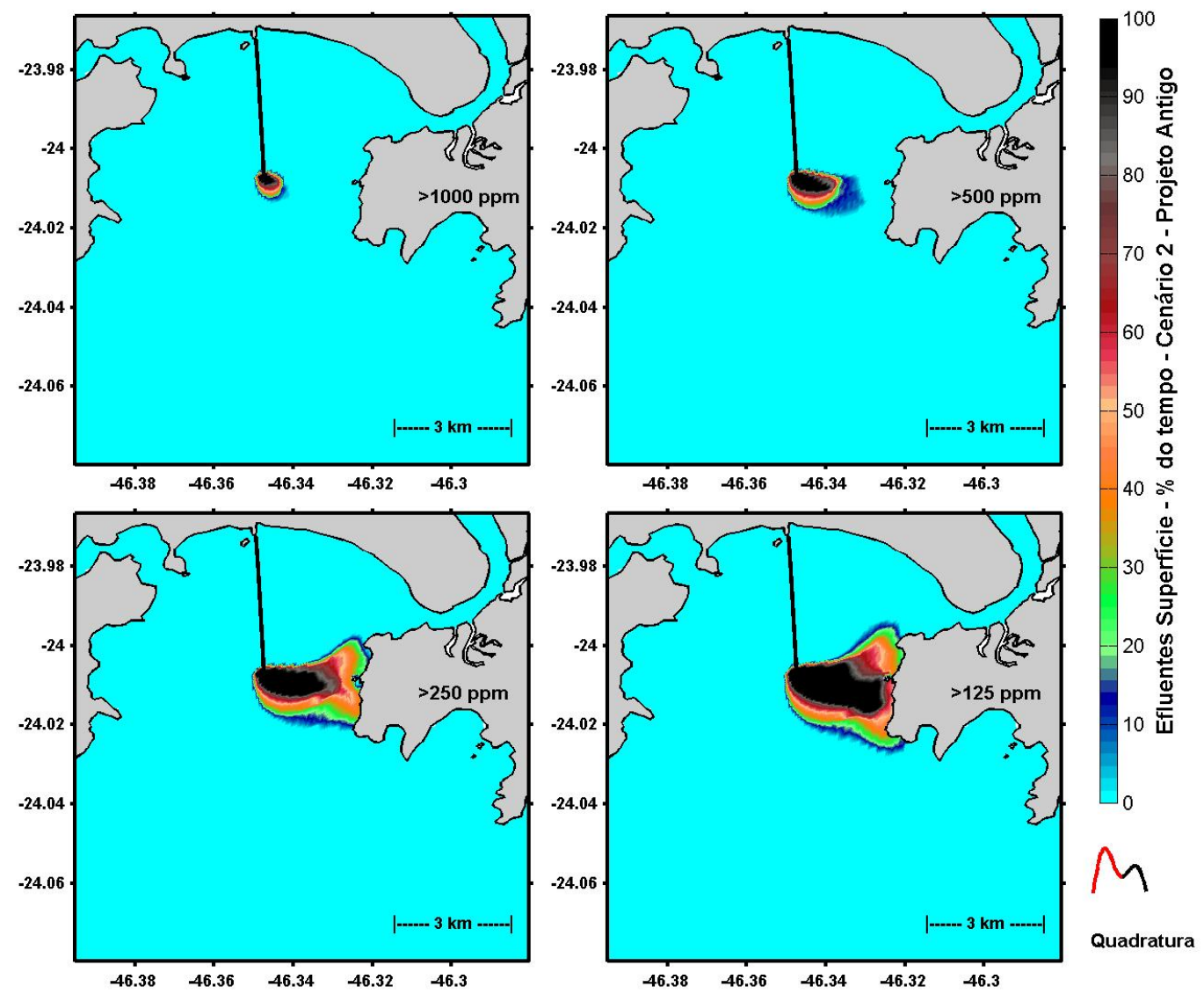

Figura 3.43: Frequência de ocorrência de concentração de efluente, em superfície, lançado pelo projeto antigo, para o período de enchente-vazante em quadratura, no cenário 2.

Comparando-se os resultados modelados nos cenários 1 e 2 para o projeto antigo (Figuras 3.37 e 3.43), observa-se grande similaridade quanto às extensões das plumas, porém no cenário 2 a orientação é para leste, e não para o norte. Esta mudança de direção faz com que as praias de Santos não sejam atingidas pelos efluentes em concentrações superiores a 125 ppm, porém a costa oeste do Guarujá é afetada diretamente. A costa oeste do Guarujá é atingida por concentrações acima de 125 ppm em aproximadamente $70 \%$ do tempo. Já concentrações acima de 250 ppm interceptam a costa em aproximadamente $35 \%$ do tempo.

No projeto novo ocorrem as mesmas diferenças modeladas para o projeto antigo no período de quadratura dos cenários 1 e 2. Entre estes dois cenários (Figuras 3.38 e 3.44), as plumas apresentam as mesmas distribuições horizontais, porém a orientação é para leste no último, atingindo desta forma a costa oeste do Guarujá. Em concentrações superiores a 250 ppm, a costa é interceptada em cerca de $30 \%$ 


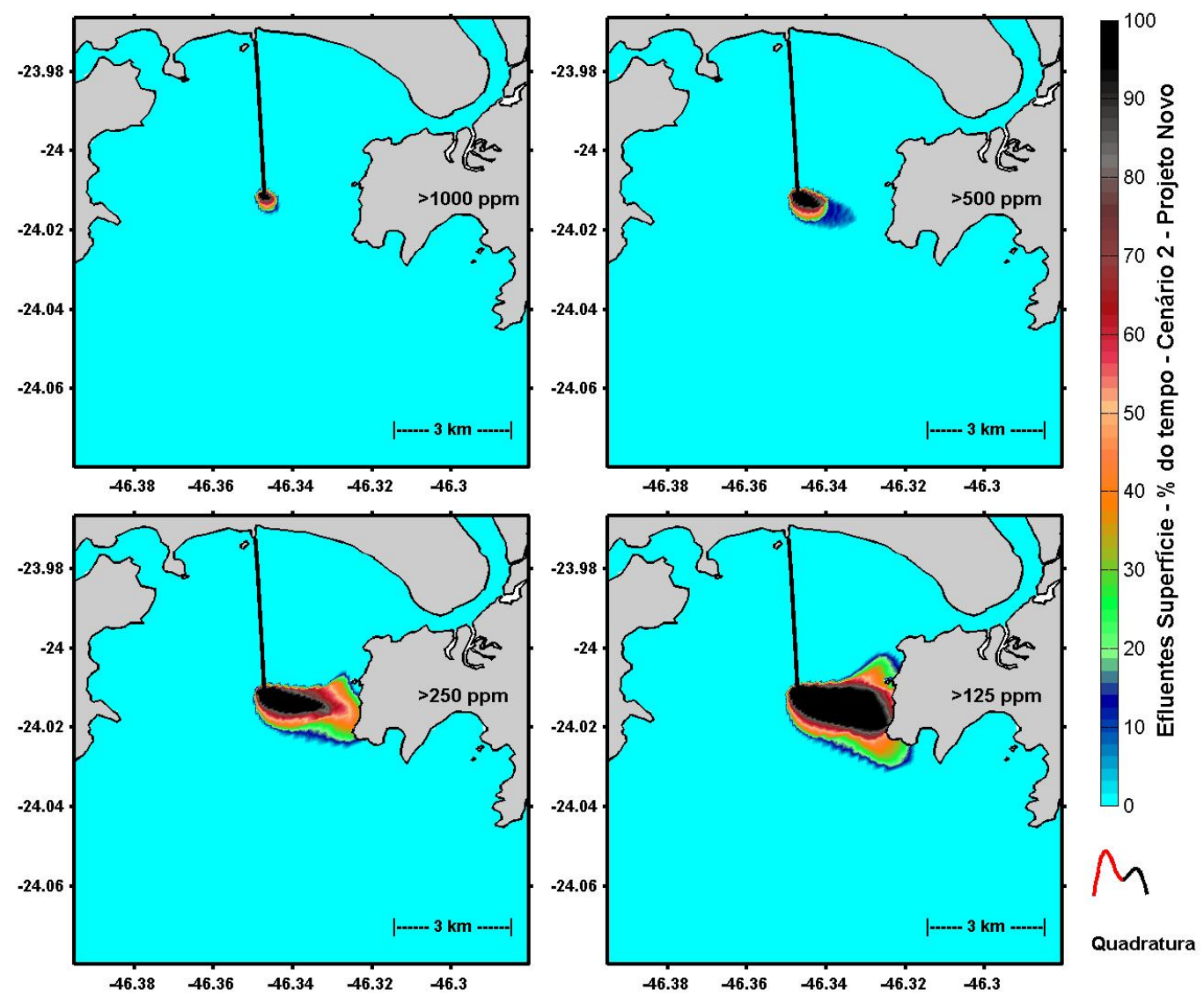

Figura 3.44: Frequência de ocorrência de concentração de efluente, em superfície, lançado pelo projeto novo, para o período de enchente-vazante em quadratura, no cenário 2.

do tempo. Já em concentrações superiores a 125 ppm, este percentual sobe para aproximadamente $80 \%$.

Para o projeto proposto, as concentrações modeladas no cenário 2 em período de quadratura (Figura 3.45), quando comparadas ao cenário 1 (Figura 3.39) apresentam menores extensões. Concentrações acima de 125 ppm tiveram extensão máxima de $3,0 \mathrm{~km}$, direção leste. Nesta faixa de concentração, a pluma que esteve presente $100 \%$ do tempo foi modelada com extensão de $0,20 \mathrm{~km}$. Esta extensão foi a máxima obtida por concentrações superiores a 250 ppm na mesma direção. Concentrações acima de 500 ppm e 1000 ppm estiveram sempre presente somente ao redor do local de lançamento de efluentes, com extensão máxima de $0,1 \mathrm{~km}$.

As Figuras 3.46, 3.47 e 3.48 apresentam a frequência de ocorrência de concentração de efluente em superfície para o período de enchente-vazante em sizígia, no cenário 2, para os projetos antigo, novo e proposto, respectivamente.

Como descrito para o período de quadratura, a diferença entre as plumas modeladas nos cenários 1 e 2 para o projeto antigo, em período de sizígia, está no sentido: no cenário 2 (Figuras 3.46) ocorrem deslocamentos para leste. Como descrito para 


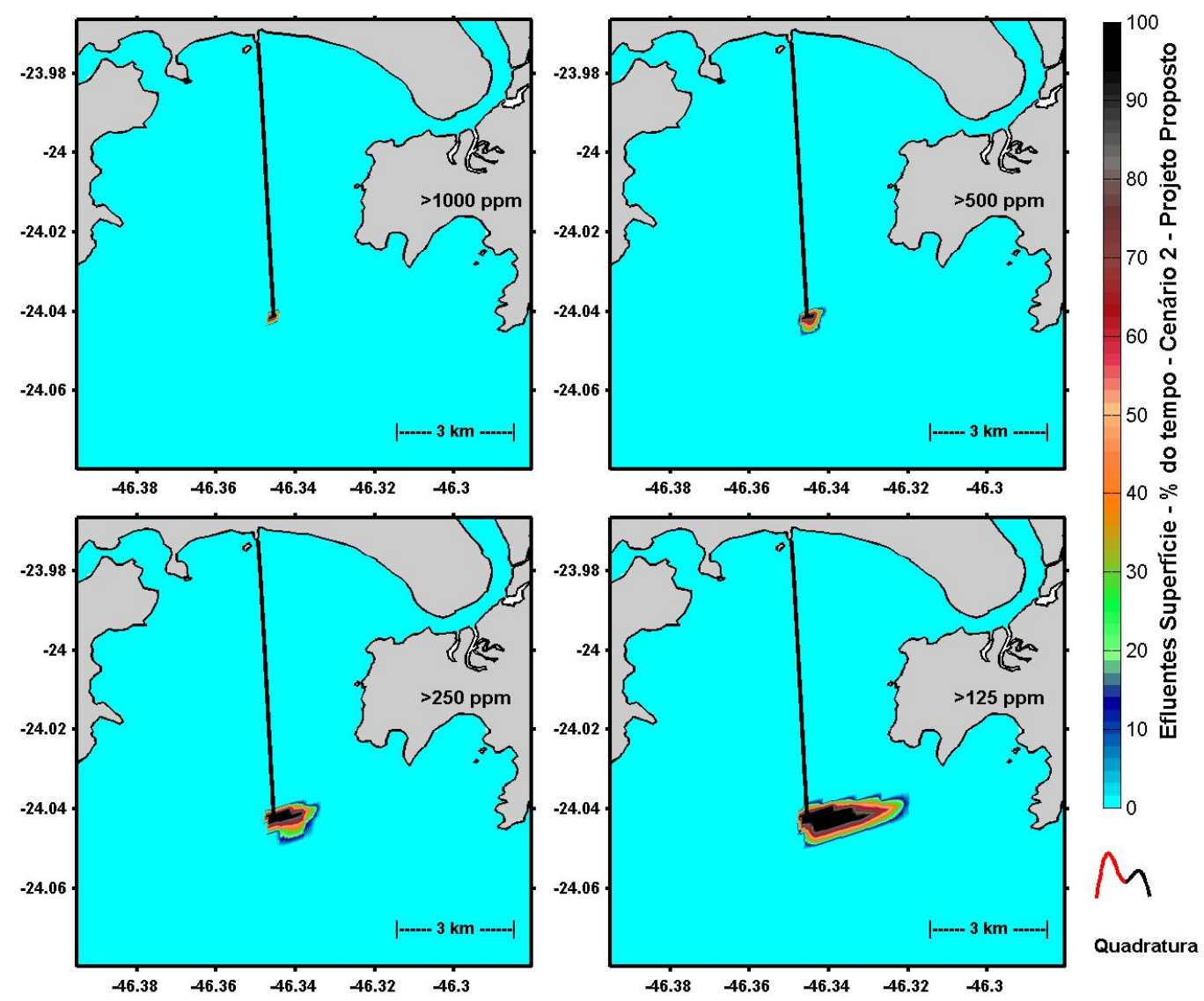

Figura 3.45: Frequência de ocorrência de concentração de efluente, em superfície, lançado pelo projeto proposto, para o período de enchente-vazante em quadratura, no cenário 2.

o cenário 1, aqui também a costa oeste do Guarujá só é atingida por efluentes em concentrações acima de 125 ppm em aproximadamente $25 \%$ do tempo. Concentrações acima de 1000 ppm somente são modeladas a distâncias de poucos metros do local de lançamento dos efluentes.

Para o projeto novo, a comparação entre os cenários 1 e 2 (Figuras 3.41 e 3.47) mostra que além de ocorrer deslocamento das plumas para o sul, como descrito para o projeto antigo, no cenário 2 não ocorre interceptação da linha de costa por concentrações superiores a 125 ppm. Comparadas com o cenário 1, as plumas apresentam-se mais diluídas, tendo desta forma suas extensões reduzidas.

O projeto proposto no cenário 2 (Figura 3.48) apresenta diferença marcante com o cenário 1 (Figura 3.42 para o período de sizígia: no primeiro as plumas apresentam extensões reduzidas. Em superfície, concentrações acima de 125 ppm são encontradas na extensão máxima de $1,5 \mathrm{~km}$ nas direções leste e sul. Concentrações acima de 250 ppm, 500 ppm e 1000 ppm estão centradas a poucos metros do local de lançamento de efluentes. 

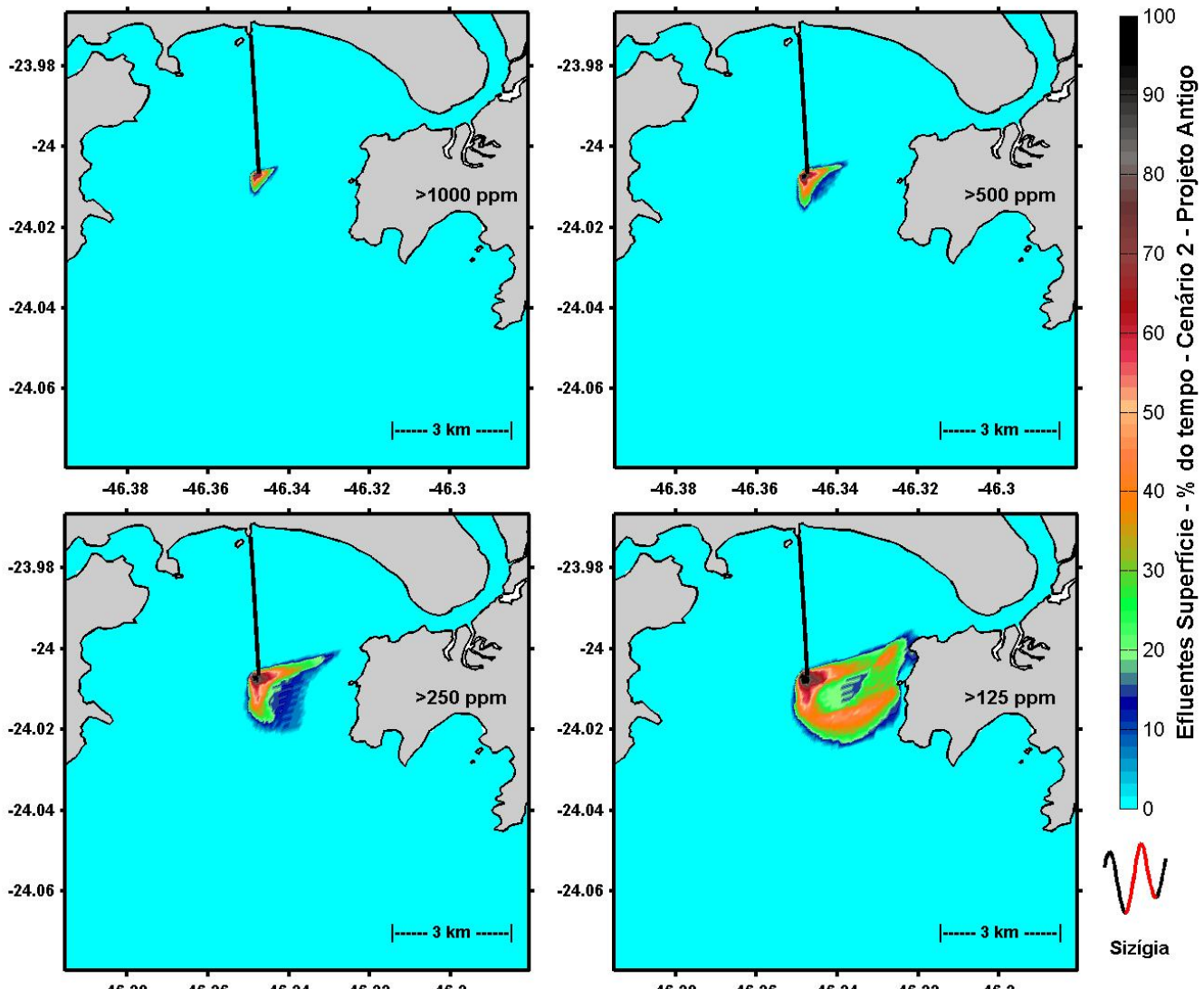

Figura 3.46: Frequência de ocorrência de concentração de efluente, em superfície, lançado pelo projeto antigo, para o período de enchente-vazante em sizígia, no cenário 2. 

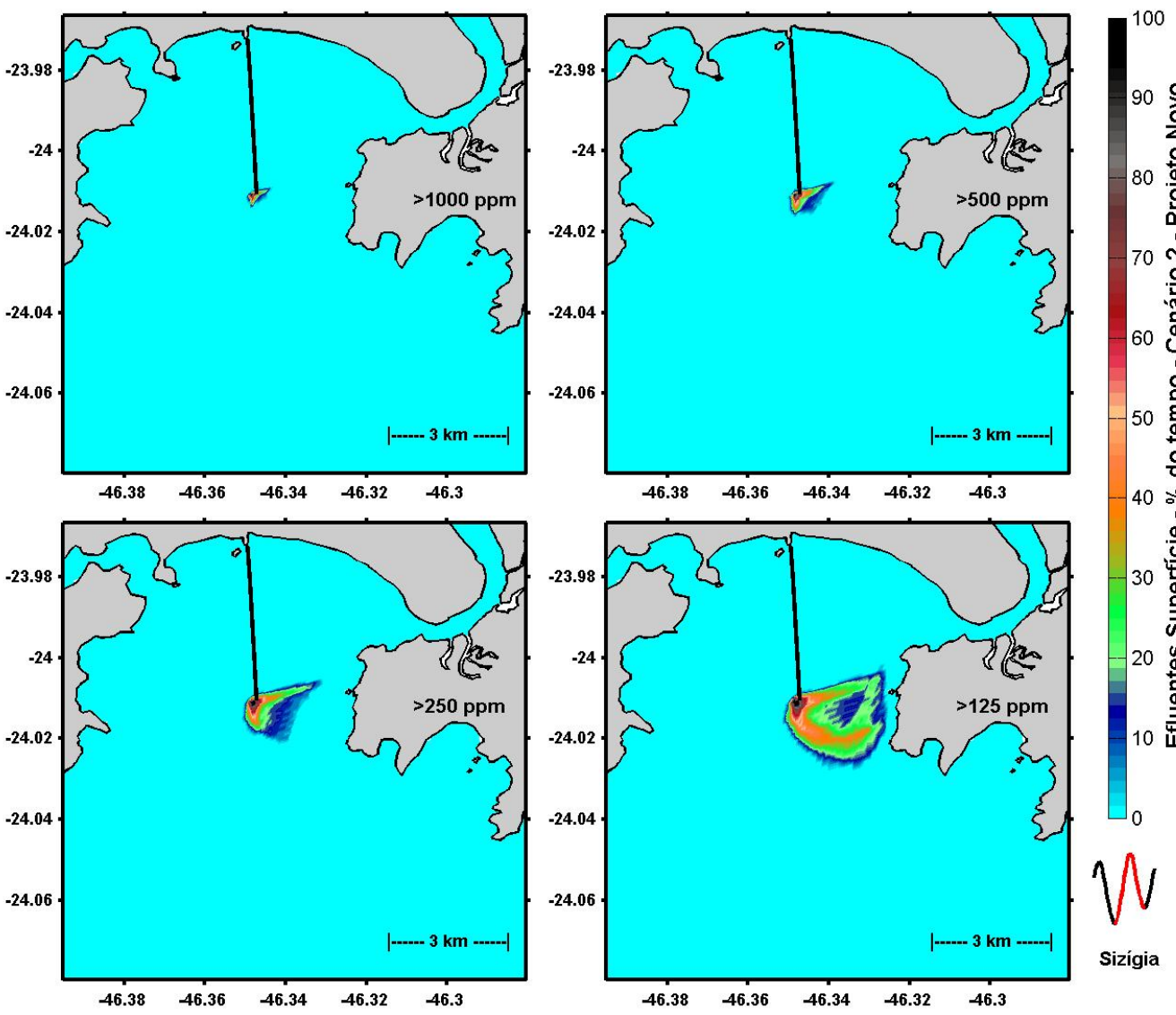

Figura 3.47: Frequência de ocorrência de concentração de efluente, em superfície, lançado pelo projeto novo, para o período de enchente-vazante em sizígia, no cenário 2 . 

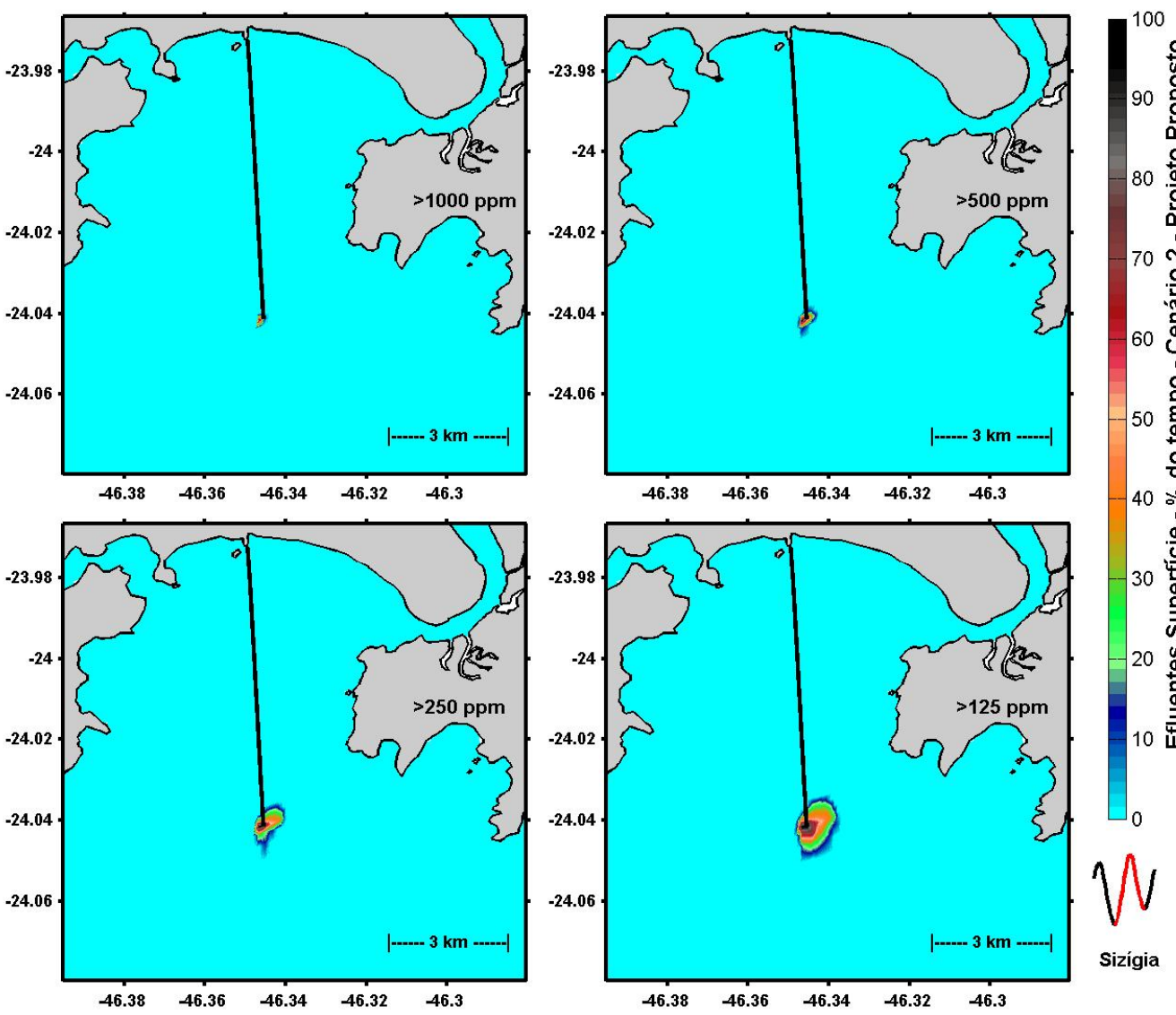

Figura 3.48: Frequência de ocorrência de concentração de efluente, em superfície, lançado pelo projeto proposto, para o período de enchente-vazante em sizígia, no cenário 2. 
O cenário 3 é aquele que apresenta as menores extensões de plumas dentre todos os cenários propostos, para os três projetos para o ESS. As Figuras 3.49, 3.50 e 3.51 apresentam as distribuições de concentração para o período de quadratura no cenário 3, e as Figuras 3.52, 3.53 e 3.54 apresentam as distribuições de concentração para o período de sizígia, em superfície.
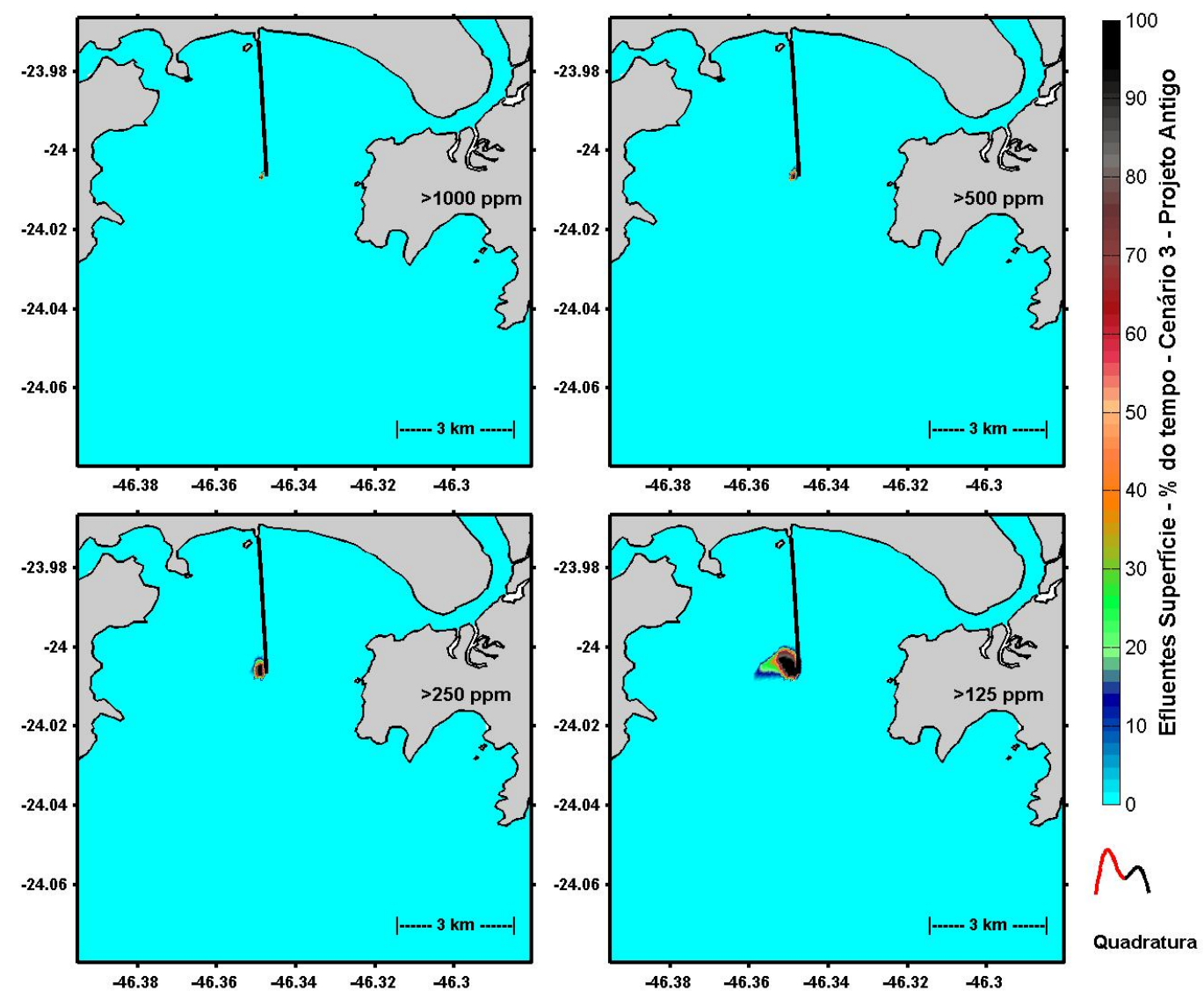

Figura 3.49: Frequência de ocorrência de concentração de efluente, em superfície, lançado pelo projeto antigo, para o período de enchente-vazante em quadratura, no cenário 3.

No período de quadratura do cenário 3, para o projeto antigo (Figura 3.49), a pluma com concentração superior a 125 ppm extende-se para oeste, à distância máxima de 1,0 km aproximadamente. Em concentrações superiores a 250 ppm, 500 ppm e 1000 ppm a pluma encontra-se localizada nas imediações do lançamento de efluentes, tendo poucas dezenas-centenas de metros de extensão.

Para o projeto novo durante o período de quadratura no cenário 3 (Figura 3.50), aplica-se as mesmas considerações feitas ao projeto antigo, quando relacionados aos cenários anteriores. As extensões apresentam-se drásticamente menores e as plumas estão orientadas na direção oeste. Em concentrações superiores a 250 ppm, 500 ppm e 1000 ppm a pluma encontra-se localizada nas imediações do lançamento de efluentes, tendo poucas centenas de metros de extensão. 


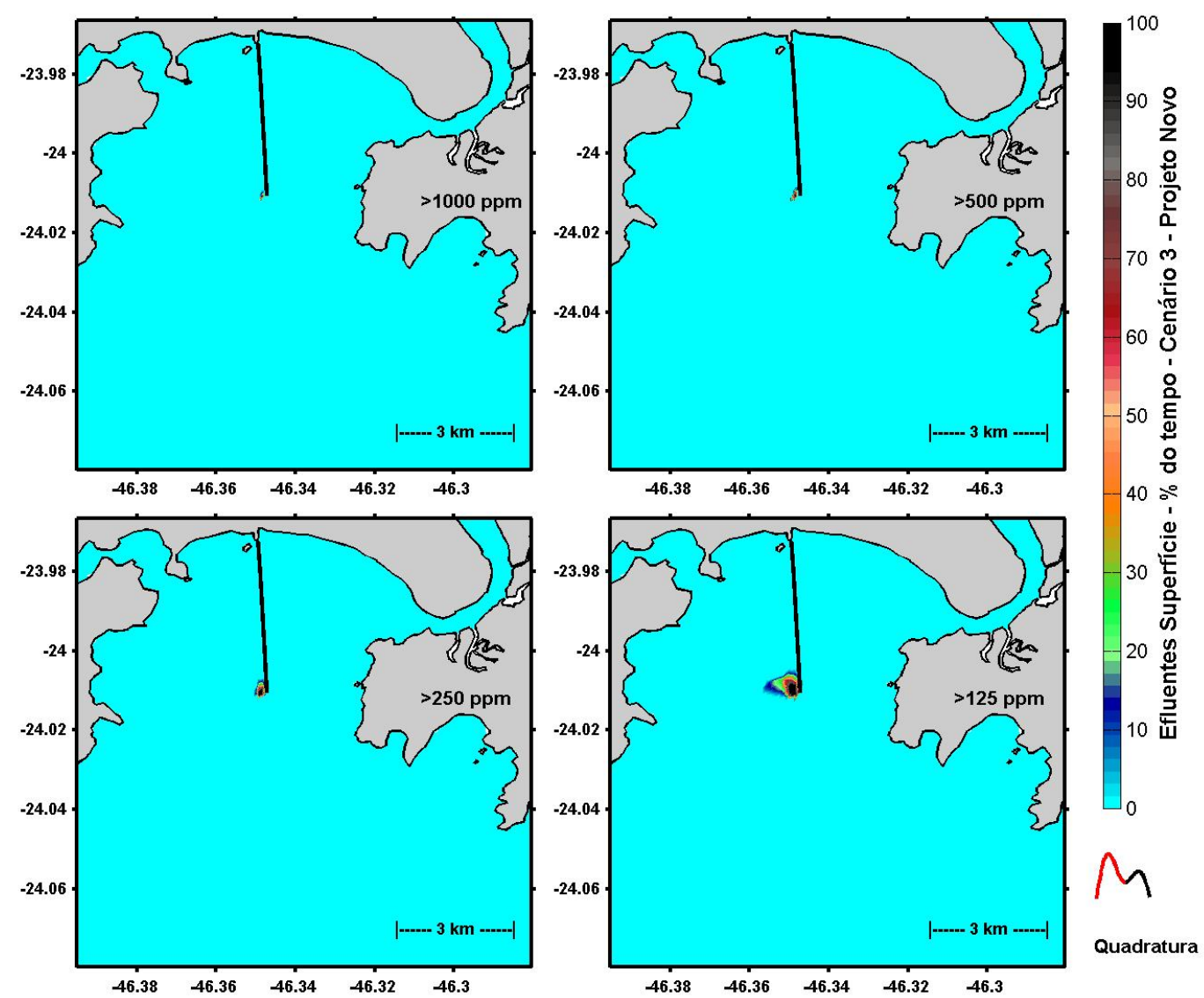

Figura 3.50: Frequência de ocorrência de concentração de efluente, em superfície, lançado pelo projeto novo, para o período de enchente-vazante em quadratura, no cenário 3.

O projeto proposto, durante o cenário 3 em período de quadratura (Figura 3.51), apresenta plumas com extensões muito reduzidas, quando comparadas àquelas do cenário 1 (Figura 3.39) e do cenário 2 (Figura 3.45) e também quando comparadas aos projetos antigo e proposto. No cenário 3, não foram modeladas concentrações superiores a 1000 ppm. Concentrações acima de 500 ppm apresentaram extensão máxima de $0,05 \mathrm{~km}$. A pluma com concentração superior a $250 \mathrm{ppm}$ apresentou extensão máxima de $0,2 \mathrm{~km}$, e $0,5 \mathrm{~km}$ foi a extensão máxima modelada para a pluma com concentração acima de 125 ppm.

No cenário 3, o projeto antigo (Figura 3.54) apresenta plumas com características diferentes das modeladas nos cenários 1 e 2 (Figuras 3.40 e 3.46) em sizígia. Neste, as plumas orientam-se ao longo do eixo sudoeste-nordeste e as extensões são menores. Concentração acima de 125 ppm foi modelada com extensão máxima de 2,2 km na direção sudeste e $1,5 \mathrm{~km}$ na direção nordeste. A direção sudeste foi a preferencial para concentrações acima de 250 ppm, 500 ppm e 1000 ppm. Nestas faixas de concentração, as extensões máximas modeladas foram de 1,5 km, 1,0 km e 0,3 km, respectivamente. 


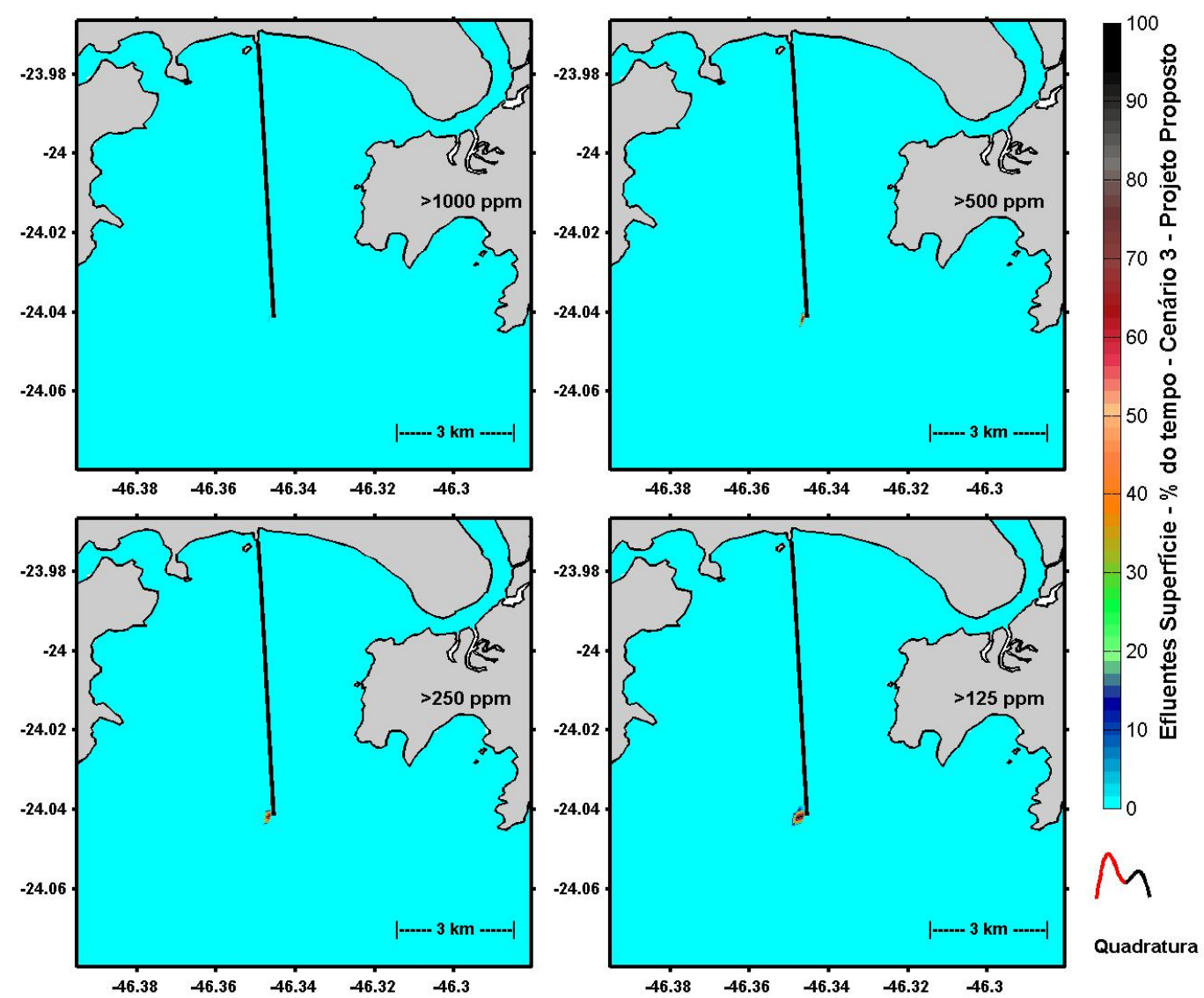

Figura 3.51: Frequência de ocorrência de concentração de efluente, em superfície, lançado pelo projeto proposto, para o período de enchente-vazante em quadratura, no cenário 3.

As plumas no cenário 3 (Figura 3.53) apresentam orientação nordeste-sudoeste, com menores concentrações na camada superficial. A maior extensão modelada foi para concentrações acima de 125 ppm, em sentido sudeste. Para as concentrações acima de $250 \mathrm{ppm}$, a extensão máxima modelada foi de $0,3 \mathrm{~km}$, porém no sentido oeste,. Plumas com concentrações superiores a 250 ppm e 125 ppm apresentaram extensões reduzidas (máxima de 200 m) na direção oeste.

O projeto proposto durante o cenário 3 em período de sizígia (Figura 3.54) apresenta plumas com extensões muito reduzidas, quando comparados os resultados com o cenário 1 (Figura 3.42 e com o cenário 2 (Figura 3.48). No cenário 3, não foram modeladas concentrações superiores a 1000 ppm. Concentrações acima de 500 ppm apresentaram extensão máxima de $0,1 \mathrm{~km}$ no sentido oeste. Concentrações acima de 250 ppm e 125 ppm apresentaram extensão máxima de 0,3 km e 0,5 km respectivamente. 

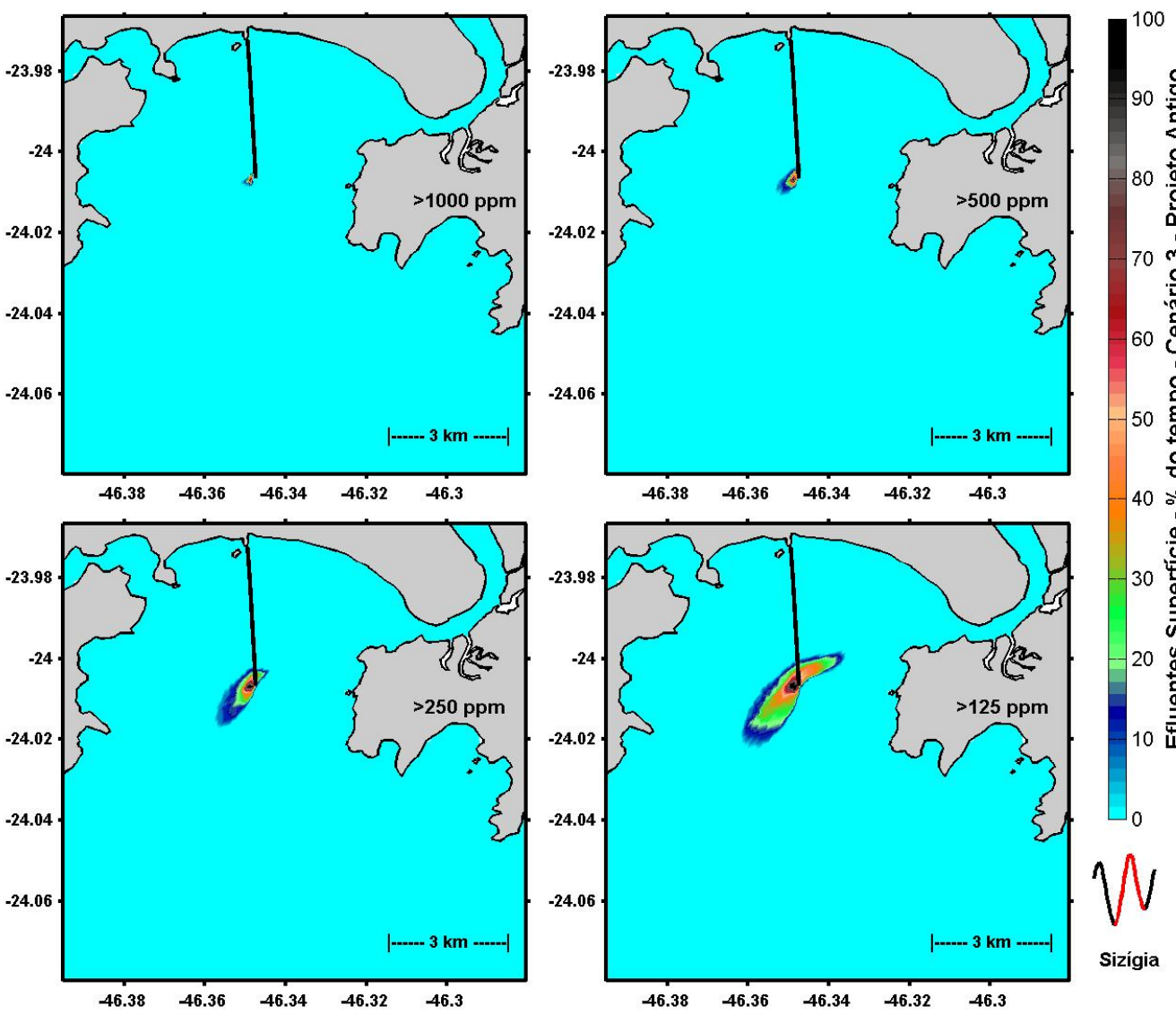

Figura 3.52: Frequência de ocorrência de concentração de efluente, em superfície, lançado pelo projeto antigo, para o período de enchente-vazante em sizígia, no cenário 3 . 



Figura 3.53: Frequência de ocorrência de concentração de efluente, em superfície, lançado pelo projeto novo, para o período de enchente-vazante em sizígia, no cenário 3 . 

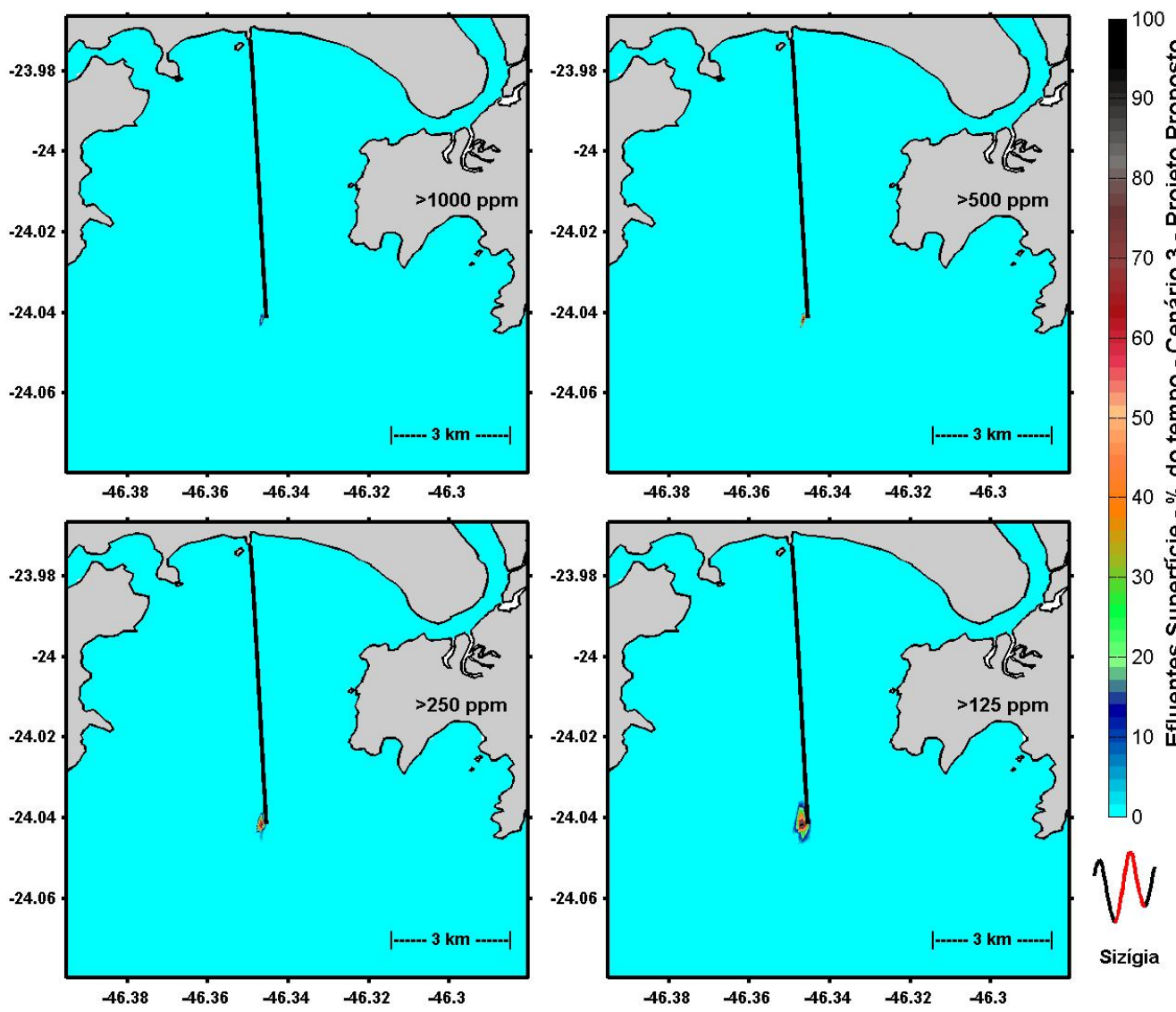

Figura 3.54: Frequência de ocorrência de concentração de efluente, em superfície, lançado pelo projeto proposto, para o período de enchente-vazante em sizígia, no cenário 3 . 


\section{Capítulo 4}

\section{Discussão}

Neste Capítulo serão discutidos os resultados obtidos para o sistema frontal climatológico, pelos experimentos hidrodinâmicos, de campo próximo e campo distante.

\subsection{Sistema frontal climatológico}

Segundo a climatologia de sistema frontal obtida nesta Dissertação de Mestrado, durante os meses de verão ocorrem em média 10,3 passagens de frentes frias na BS, com desvio padrão de 1,7. Coelho (2007), a partir de dados de vento provenientes do modelo numérico do European Center for Medium Range Weather Forecast (ECMWF) para os meses de verão dos anos de 1998 a 2005, identificou doze frentes frias que passaram entre os Cabos de Santa Marta (SC) e de São Tomé (RJ). O Boletim Climanálise, desde janeiro de 1996, identifica a passagem de frentes frias, na forma de gráficos, como apresentado na Figura 4.1. Nesta Figura, está representada a passagem de 4 sistemas frontais pela região de Santos. Para período entre janeiro de 1996 e março de 2007, o Boletim Climanálise apontou média de 11,2 com desvio padrão de 4,1 passagens de frentes frias por Santos durante os meses de verão.

A climatologia descrita por Coelho (2007) apresenta um número menor de passagens de sistemas frontais quando comparado ao valor obtido por este estudo, pois considerou apenas sistemas que percorreram toda a plataforma continental sudeste. Já os valores obtidos pelo Boletim Climanálise para os anos de 1996 a 2007 condizem com os resultados desta Dissertação.

Segundo Coelho (2007) a evolução local dos ventos na Plataforma Continental Sudeste é a seguinte: no instante inicial, a direção do vento é de noroeste e oeste, indicando um cenário pré-frontal. Doze horas depois estão presentes os ventos de sudoeste. Esta Dissertação aponta a inversão total dos ventos do quadrante norte para o quadrante sul também em aproximadamente 12 h; porém, o sistema pré- 


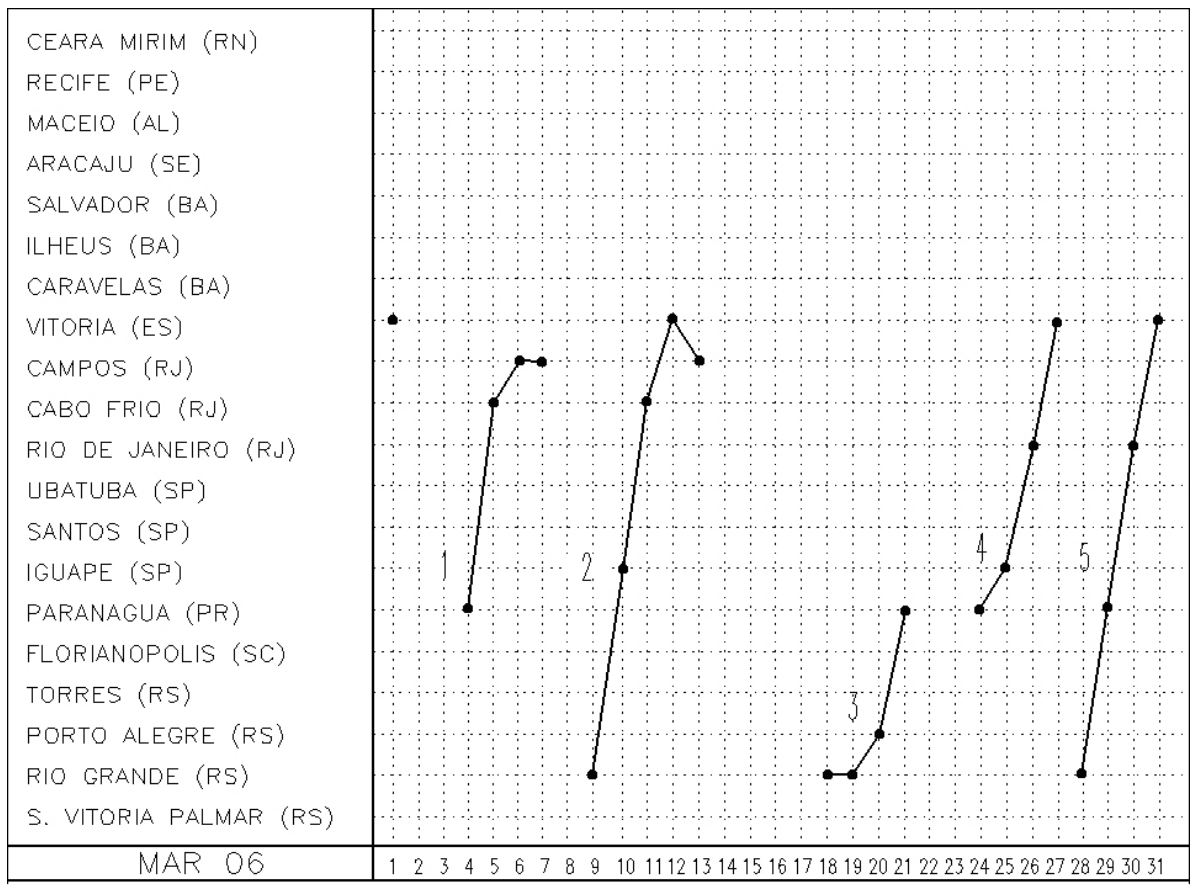

Figura 4.1: Seções estação versus tempo dos sistemas frontais que penetraram no Brasil em JANEIRO/2006. As linhas indicam que a frente passou pela estação entre 09h00 (hora local) do dia anterior e 09h00 (horal local) do dia indicado (CPTEC/INPE 1996).

frontal é caracterizado por ventos mais intensos de nordeste, girando para leste. Provavelmente, como neste estudo utilizamos dados submetidos a um filtro passa baixa em período de $30 \mathrm{~h}$, a rápida variação para o quadrante noroeste foi perdida. Após a entrada do sistema frontal, este estudo aponta ventos com origem sudeste, diferente de Coelho (2007) que obteve ventos com origem sudoeste.

\subsection{Simulações hidrodinâmicas}

Para as simulações hidrodinâmicas, o nível do mar apresentou oscilações semidiurnas com amplitudes variando entre $0,25 \mathrm{~m}$ para períodos de quadratura e 1,95 para períodos de sizígia no CP. Segundo Harari et al. (2000), a variação da maré é de 0,27 m em situação de quadratura e 1,23 m em sizígia para a BS. Como forma de validação do modelo hidrodinâmico proposto, na Figura 4.2 são plotadas as curvas geradas pelo modelo no cenário 1 (sem vento) e a previsão de maré para o Porto de Santos realizada pela DHN (2007).

Comparando-se os resultados modelados com os resultados da previsão da DHN, observa-se similaridade entre as curvas. As maiores diferenças são observadas quanto à amplitude dos resultados do modelo, que são maiores. Uma explicação plausível para este fato é a quantidade de constituintes astronômicas utilizadas na simulação 


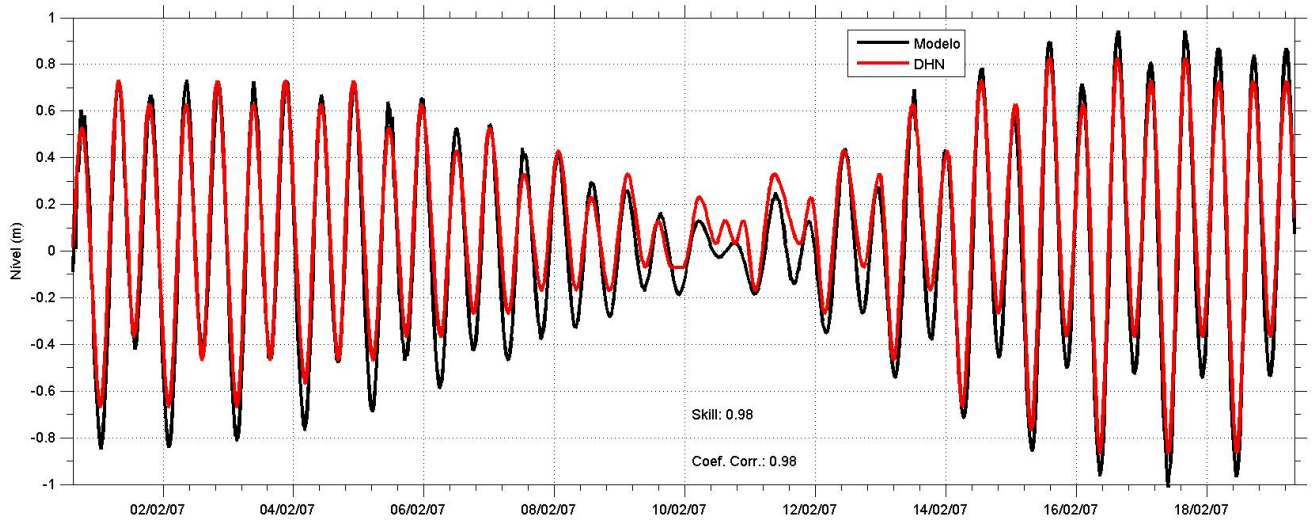

Figura 4.2: Variação do nível do mar na posição $23,95^{\circ} \mathrm{S}, 46,30^{\circ} \mathrm{O}$ para o cenário 1 (linha em preto) e para a previsão da DNH no mesmo ponto (linha em vermelho).

e na previsão. Conforme descrito na Seção 2.6, foram usadas nas simulações hidrodinâmicas 10 componentes harmônicas (Tabela 2.2. Já as previsões realizadas pela DHN para o Porto de Santos são realizadas com a informação de 45 componentes. O coeficiente de correlação entre as duas curvas e o valor do Skill foram ambos iguais a 0,98. Skill (S) é o método proposto por Wilmott (1981) e descrito por Warner et al. (2005), baseado no cálculo da quantidade adimensional da equação 4.1.

$$
S=1-\frac{\sum\left|X_{\text {mod }}-X_{o b s}\right|^{2}}{\sum\left(\left|X_{\text {mod }}-\left(X_{o b s}^{-}\right)\right|+\left|X_{o b s}-\left(X_{o b s}{ }^{-}\right)\right|\right)^{2}}
$$

onde, $X_{m o d}$ é o valor modelado, $X_{o b s}$ é o valor observado e $\overline{X_{o b s}}$ é o valor médio observado. Quando $S=1$ há concordância total entre os resultados modelados e as observações. No outro extremo, quando $S=0$ a concordância é nula.

As simulações forçadas pelo vento médio (cenário 2) ou pela passagem de sistema frontal (cenário 3), tanto em sizígia quanto em quadratura, apresentaram resultados semelhantes para as elevações da superfície, diferindo no máximo em $10^{-2} \mathrm{~m}$ tanto na região oceânica quanto na estuarina.

Harari et al. (2000) afirma que as ondas de maré propagam-se simultaneamente pelos Canais do Porto, de São Vicente e de Bertioga. Os experimentos numéricos desta Dissertação comprovam essa propagação, conforme descrito na Seção 3.2.1.

Fúlvaro \& Ponçano (1976) apud Marques (2006) descrevem em situação preamar, correntes superficiais fluindo da costa em direção ao mar aberto, na porção mediana da BS. Já em situação de baixamar, há evidências de ocorrência de movimentos anti-horários no interior da BS. Esses dois tipos de circulação, em fases diferentes de maré também foram evidenciados por este estudo, principalmente os movimentos anti-horários identificados no interior da BS, os quais são amplificados ou reduzidos segundo a maré de sizígia ou de quadratura, conforme descrito na Seção 3.2.2. Ainda sobre o interior da BS, Marques (2006) analisou correntes observadas e apresentou 
resultados da magnitude das correntes da ordem de $\mathrm{cm} . \mathrm{s}^{-1}$, com maiores valores na desembocadura do CSV na BS, conforme também obtido por este estudo.

O projeto ECOSAN instalou um correntógrafo tridimensional, comumente chamado de ADCP (Acoustic Dopplet Current Profiler), que mede as correntes ao longo da coluna dágua, na isóbata de $20 \mathrm{~m}$, no lado leste da saída da BS, próximo à Ilha da Moela. Este ADCP ficou fundeado entre os meses de março e abril de 2006. Os dados provenientes do ADCP para o mês de março de 2006, juntamente com os dados de vento da Laje de Santos e com os dados de elevação no nível do mar obtidos junto à DHN para o porto de Santos, podem ser observados no painel a) da Figura 4.3 . Nessa mesma Figura, nos painéis b) e c), estão apresentados os resultados numéricos deste estudo para os cenários 1 e 3, respectivamente.

Embora os períodos de simulação numérica deste estudo (fevereiro de 2007) sejam diferentes dos amostrados pelo ADCP do projeto ECOSAN (março de 2006), ambos englobam meses de verão. Serão comparados dados modelados com dados observados em intervalos de tempo que apresentem as mesmas características quanto à maré (sizígia e quadratura) e vento (vento médio ou passagem de sistema frontal).

O período I destacado no painel a) da Figura 4.3 em amarelo, mostra quase um dia com vento de nordeste, em maré de quadratura. As correntes medidas apresentam sentido preferencial para sudeste, variando com o ciclo de maré, e as magnitudes decrescendo com o aumento da profundidade. A ordem de grandeza destas correntes é de $10 \mathrm{~cm} . \mathrm{s}^{-1}$. Quando comparado ao período I destacado no painel b) em amarelo (resultados do modelo hidrodinâmico para o cenário 2), é notada similaridade entre ambos. Neste período, os resultados modelados também estão sendo forçados por vento de nordeste, em maré de quadratura. As correntes apresentam sentido preferencial para sudeste, com cisalhamento vertical principalmente na intensidade e magnitudes da ordem da $10 \mathrm{~cm} \cdot \mathrm{s}^{-1}$. Na profundidade de $2,0 \mathrm{~m}$, a componente $u$ da velocidade apresentou Skill de 0,45 entre o resultado modelado e o observado. Nesta profundidade, a componente $v$ apresentou Skill de 0,48. Em 16,0 m, o Skill para as componentes $u$ e $v$ da velocidade foram 0,47 e 0,50 , respectivamente.

O período II destacado em azul no painel a) da Figura 4.3, mostra quase um dia com vento de nordeste, em maré de sizígia. As correntes medidas apresentam sentido preferencial para sudeste, variando com o ciclo de maré, e as magnitudes decrescendo com o aumento da profundidade. A ordem de grandeza destas correntes é de $10 \mathrm{~cm} . \mathrm{s}^{-1}$. Quando comparado ao período II destacado em azul no painel b) (resultados do modelo hidrodinâmico para o cenário 2), é notada similaridade entre ambos. Neste período, os resultados modelados também estão sendo forçados por vento de nordeste, em período de sizígia. As correntes apresentam sentido preferencial para sudeste, com cisalhamento vertical principalmente na intensidade e magnitudes da ordem da $10 \mathrm{~cm} . \mathrm{s}^{-1}$. Quando comparadas as correntes entre os 


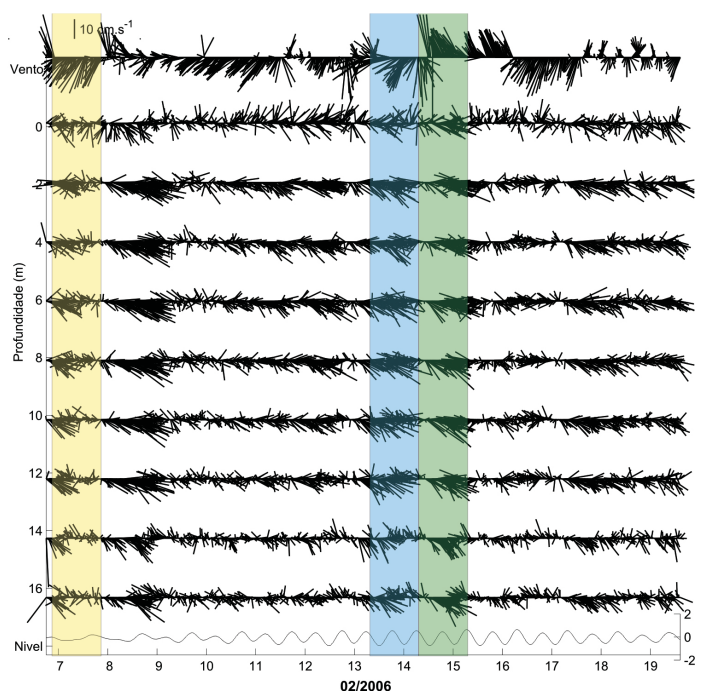

(a) ADCP

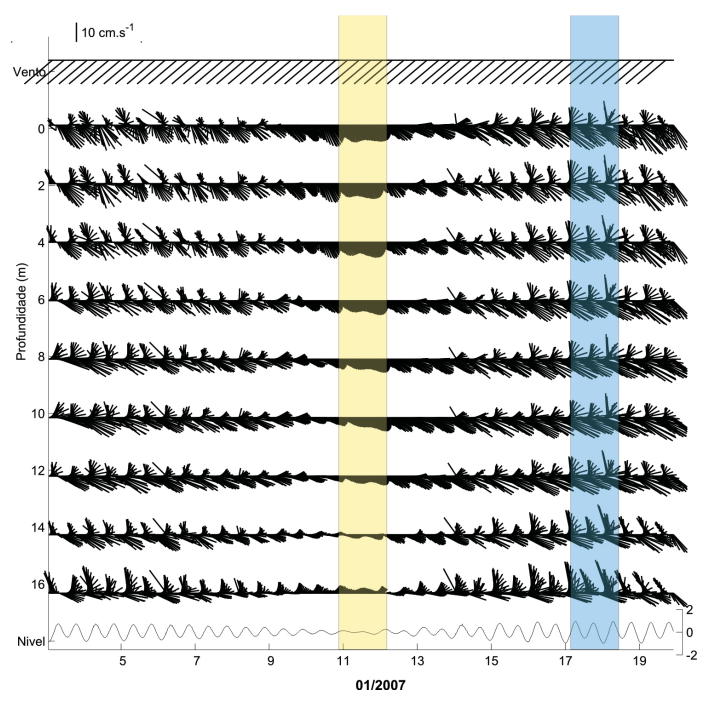

(b) Modelo - Vento Médio

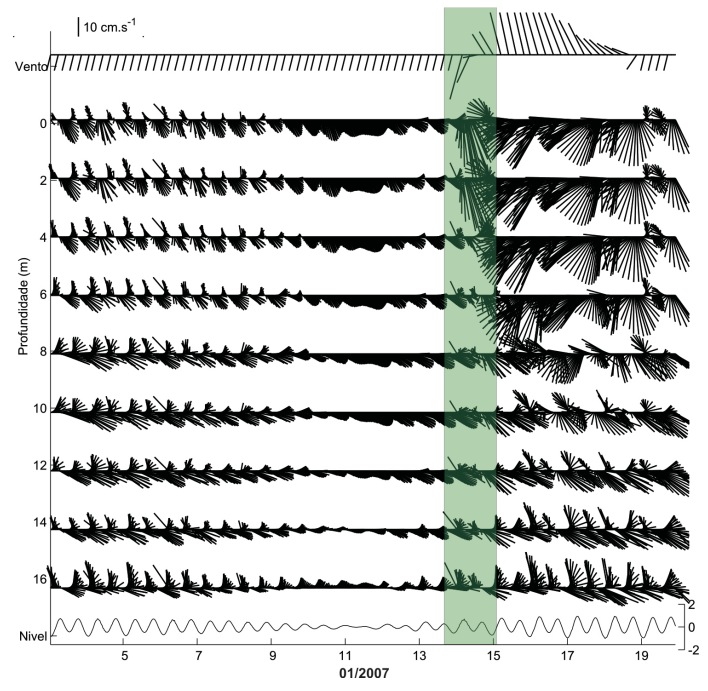

(c) Modelo - Vento Frente

Figura 4.3: Ventos, correntes modeladas e observadas, e variações do nível do mar nas proximidades da Ilha da Moela, a leste da saída da BS. As magnitudes do vento estão multiplicadas por $10^{-1}$. O painel superior (a) apresenta ventos medidos na Laje de Santos, correntes medidas por ADCP fundeado na isóbata de $20 \mathrm{~m}$ e oscilação do nível do mar no Porto de Santos obtidas pela DHN. O painel inferior da esquerda (b) apresenta resultados obtidos nos experimentos numéricos forçados pelo vento médio. O painel inferior da direita (c) apresenta resultados obtidos nos experimentos numéricos forçados pelo vento médio seguido da passagem de um sistema meteorológico frontal.

períodos de quadratura e sizígia, tanto nas observações quanto nos resultados do modelo, as intensidades são um pouco maiores na sizígia. Para este período, o Skill entre a velocidade modelada e a observada foi de 0,46 e 0,23 para as componentes $u$ e $v$ na profundidade de $2,0 \mathrm{~m}$. Na profundidade de $16,0 \mathrm{~m}$ este parâmetro foi de 0,47 e 0,50 , para as componentes $u$ e $v$ da velocidade, respectivamente.

O período III destacado em verde no painel a) da Figura 4.3. mostra ventos de 
norte no início, com posterior entrada de um sistema frontal e ventos de sul, em maré de sizígia. As correntes medidas apresentam, no início, significativo aumento na magnitude em direção sudeste para em seguida girarem para sudoeste. O mesmo panorama é destacado em verde no período III no painel c), que mostra os resultados do modelo hidrodinâmico para o cenário 3. As componentes $u$ e $v$ da velocidade, nas profundidade de 2,0 m e 16,0 m, apresentaram Skill de 0,29, 0,34 e 0,48, 0,39, respectivamente.

De modo geral, a BS apresentou aspectos dinâmicos regidos fortemente pela maré imposta nas bordas oceânicas, o que faz com que as descargas nas desembocaduras dos CSV e CP sejam controladas pelos instantes de baixamar e preamar, tanto em períodos de sizígia quanto de quadratura. Em instantes de baixamar, ocorre maior influência das vazões desses canais, fazendo com que as velocidades na BS sejam maiores e que águas provenientes do AES sejam despejadas na BS. Estas águas apresentam menor densidade, quando comparadas àquelas que ocupam profundidades semelhantes da região marinha adjacente. A injeção de água pelos canais estuarinos ocasiona maior misturamento da coluna de água, deixando esta mais homogênea verticalmente. Em instantes de preamar, a força do gradiente de pressão na região marinha adjacente força a entrada de águas mais densas na BS, diminuindo o fluxo de águas estuarinas pelos CSV e CP, principalmente nas porções mais próximas ao fundo. Esta entrada de água, principalmente pelas camadas inferiores na BS, faz com que a estratificação vertical seja acentuada.

O vento médio imposto no cenário 2 atuou significativamente principalmente deslocando as estruturas horizontais de circulação, principalmente em superfície, para sudoeste. Este deslocamento favorece, principalmente em instantes de baixamar, uma maior diluição das águas provenientes das regiões estuarinas na BS. Assim, quando comparada ao cenário 1, onde tal vento não foi considerado, a homogeneidade vertical das águas da BS no cenário 2 foi maior.

Maior homogeneidade vertical foi identificada nos resultados apresentados para o cenário 3. Neste cenário, que simula a passagem de um sistema frontal após período de vento médio, tanto em situação de maré de sizígia quanto de quadratura, observamos que os ventos provenientes do quadrante sul, alternando para leste, tiveram como papel principal misturar as águas da BS com águas mais densas, fazendo com que fosse identificada grande variação lateral das propriedades mas pequena variação na vertical. Este cenário é favorecido em instantes de preamar. A partir destas considerações, pode-se apresentar o esquema de circulação da Figura 4.4. 


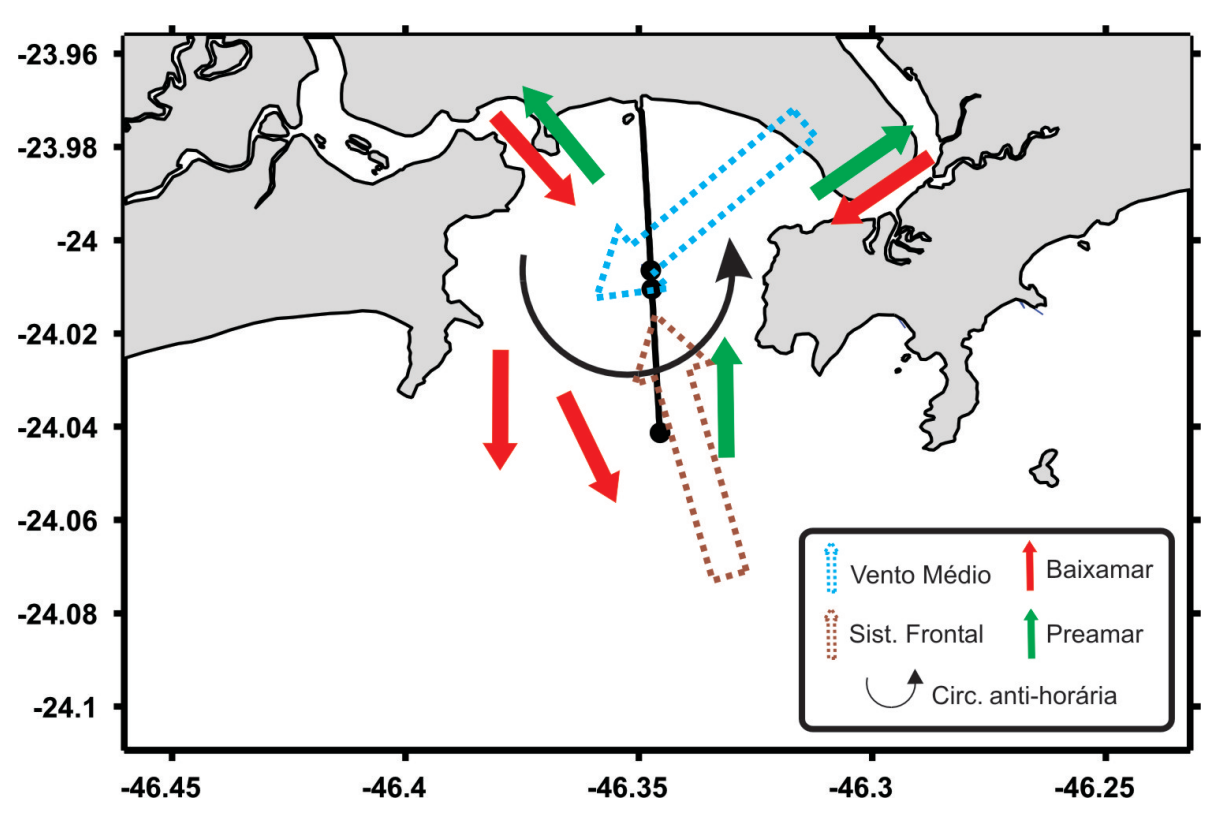

Figura 4.4: Esquema simplificado da circulação superficial na Baía de Santos em instantes de preamar e baixamar, com a presença de vento médio ou sistema frontal.

\subsection{Simulações da dispersão no campo próximo}

A Tabela 4.1 mostra os resultados obtidos para a estratificação bruta nos projetos proposto, novo e antigo para os instantes de baixamar e preamar, em sizígia e quadratura, para os cenários 1, 2 e 3.

Notamos que as maiores estratificações ocorreram no cenário 1, contrapondo as menores no cenário 3, reafirmando a maior homogeneidade vertical descrita na seção 4.2. Em todos os cenários, os instantes de quadratura apresentaram maiores estratificações que os instantes de sizígia. Nos cenários 1 e 2, o projeto antigo apresentou a maior estratificação em momentos de quadratura e, o projeto proposto, os maiores valores em sizígia. No cenário 3, a maior estratificação sempre foi alcançada pelo projeto proposto, tanto em quadratura quanto em sizígia.

Segundo Castro (1996), em águas costeiras de latitudes médias, os mecanismos físicos que podem causar aumento da estratificação são: aquecimento superficial, descarga estuarina, precipitação atmosférica e advecção de densidade. Outros processos são responsáveis pela diminuição da estratificação: resfriamento superficial, evaporação, cisalhamento superficial e cisalhamento profundo. Comparando os períodos de quadratura e sizígia, este último apresenta correntes mais intensas, fazendo com que o cisalhamento no fundo seja acentuado. O mesmo ocorre para o cisalhamento superficial, quando comparados os cenários 1, 2 e 3. Estes dois fatores fazem com que os períodos de sizígia no cenário 3, apresentem os menores valores de estratificação bruta.

Os valores de estratificação bruta em conjunto com os cisalhamentos superficial e 
Tabela 4.1: Estratificação bruta $\left(\mathrm{kg} \cdot \mathrm{m}^{-3}\right)$ nos projetos proposto, novo e antigo para os instantes de baixamar e preamar, em sizígia e quadratura, para os cenários 1, 2 e 3. B - Baixamar, P-Preamar, Q-Quadratura, S-Sizígia.

\begin{tabular}{|c|c|c|c|}
\hline Cenário & Projeto Proposto & Projeto Novo & Projeto Antigo \\
\hline $1-\mathrm{BQ}$ & 1,46 & 1,45 & 1,51 \\
$1-\mathrm{PQ}$ & 1,42 & 1,48 & 1,49 \\
$1-\mathrm{BS}$ & 1,28 & 0,97 & 0,97 \\
$1-\mathrm{PS}$ & 1,34 & 1,14 & 1,18 \\
\hline \hline $2-\mathrm{BQ}$ & 1,33 & 1,48 & 1,55 \\
$2-\mathrm{PQ}$ & 1,29 & 1,37 & 1,38 \\
$2-\mathrm{BS}$ & 1,12 & 0,89 & 0,88 \\
$2-\mathrm{PS}$ & 1,13 & 1,04 & 1,08 \\
\hline \hline $3-\mathrm{BQ}$ & 0,70 & 0,43 & 0,40 \\
$3-\mathrm{PQ}$ & 0,78 & 0,49 & 0,46 \\
$3-\mathrm{BS}$ & 0,71 & 0,40 & 0,38 \\
$3-\mathrm{PS}$ & 0,75 & 0,51 & 0,51 \\
\hline
\end{tabular}

profundo, alteram significativamente as características dos jatos e das plumas, tanto no campo próximo quanto no distante. A Tabela 4.2 resume os resultados obtidos para as características das plumas estabelecidas ao final do campo próximo, para os cenários 1,2 e 3, nos projetos proposto, novo e antigo, em instantes de baixamar e preamar de quadratura e sizígia.

De acordo com as Tabelas 4.1 e 4.2, apenas nos instantes de baixamar de sizígia nos cenários 1 e 2 a concentração da pluma estabelecida ao final do campo próximo para o projeto proposto é superior ao do projeto novo. Nestes dois cenários, que apresentam em média as maiores estratificações, estes dois instantes de tempo foram os que apresentaram a maior diferença entre as estratificações brutas dos projetos novo e proposto, sendo os valores menores no novo. Em média, os experimentos que apresentaram menores concentrações ao final do campo próximo foram obtidos no cenário 3, destacando-se o instante de preamar de sizígia. Neste instante de tempo, as correntes mais intensas e os maiores cisalhamentos superficial e profundo foram modelados. Além disso nele ocorrem as maiores diferenças de velocidade e nível comparativamente com os instantes de baixamar. Entretanto, as maiores concentrações foram obtidas em baixamar de quadratura no cenário 2, da mesma forma que nos demais cenários. Portanto, quanto menor a estratificação e mais intensas as correntes e os cisalhamentos superficial e profundo, menor será a concentração ao final do campo próximo.

A Figura 4.5 apresenta histogramas de distribuição de diluição modeladas ao final do campo próximo para os projetos antigo (a), novo (b) e proposto (c) ao longo de ciclos de enchente-vazante para o cenários ambientais propostos. Para o projeto antigo, a maior diluição ao final do campo próximo foi de aproximadamente 30 , 
Tabela 4.2: Características das plumas ao final do campo próximo, para os cenários 1,2 e 3, nos projetos proposto, novo e antigo. B - Baixamar, P-Preamar, QQuadratura, S-Sizígia, DH - Deslocamento Horizontal, D - Diâmetro, $[C]$ - Concentração, PP - Proposto, NV - Novo, AT -Antigo

\begin{tabular}{|c|c|c|c|c|c|c|c|c|c|c|}
\hline & AT & NV & PP & AT & NV & PP & AT & NV & PP \\
\hline Cenário & \multicolumn{3}{|c|}{ DH $(\mathrm{m})$} & \multicolumn{3}{c|}{ D $(\mathrm{m})$} & \multicolumn{3}{|c|}{$\left[\mathrm{C} \times 10^{5}\right](\mathrm{ppm})$} \\
\hline \hline 1 - BQ & 0,1 & 0,1 & 1,0 & 3,4 & 3,6 & 5,8 & 0,30 & 0,22 & 0,13 \\
\hline 1 - PQ & 0,2 & 0,3 & 1 & 5,2 & 5,0 & 5,5 & 0,26 & 0,18 & 0,14 \\
\hline 1 - BS & 1,8 & 5,0 & 2,5 & 4,6 & 7,1 & 8,1 & 0,21 & 0,08 & 0,14 \\
\hline 1 - PS & 1,6 & 2,0 & 2,4 & 4,0 & 4,6 & 8,9 & 0,26 & 0,17 & 0,11 \\
\hline \hline 2 - BQ & 0,1 & 0,1 & 0,8 & 3,4 & 3,5 & 5,5 & 0,30 & 0,25 & 0,19 \\
\hline 2 - PQ & 0,2 & 0,3 & 0,5 & 5,4 & 5,4 & 6,15 & 0,28 & 0,19 & 0,19 \\
\hline 2 - BS & 1,8 & 4,6 & 2,9 & 4,8 & 7,0 & 8,1 & 0,21 & 0,09 & 0,11 \\
\hline 2 - PS & 0,6 & 1,0 & 2,1 & 5,1 & 5,7 & 8,0 & 0,20 & 0,14 & 0,11 \\
\hline \hline 3 - BQ & 0,2 & 0,3 & 0,8 & 3,8 & 3,8 & 3,9 & 0,24 & 0,18 & 0,16 \\
\hline 3 - PQ & 0,4 & 0,7 & 1,2 & 4,4 & 3,6 & 8,0 & 0,23 & 0,20 & 0,12 \\
\hline 3 - BS & 2,9 & 3,0 & 1,9 & 4,2 & 5,7 & 5,9 & 0,22 & 0,12 & 0,11 \\
\hline 3 - PS & 1,9 & 2,9 & 3,0 & 4,6 & 5,7 & 6,0 & 0,20 & 0,12 & 0,10 \\
\hline
\end{tabular}

com frequência de $14 \%$. Neste mesmo projeto, a maior diluição modelada foi de aproximadamente 74. Para o projeto novo, a maior diluição modelada ao final do campo próximo foi de aproximadamente 52, com frequência de $16 \%$. No projeto novo, a maior diluição modelada foi de 138. Já o projeto proposto apresentou maior diluição modelada ao final do campo próximo, de 72 aproximadamente, com máximo de 148.

Para os projeto antigo e novo, as menores diluições ao final do campo próximo ocorrem em período de quadratura no cenário 1 (cor vermelha). Para o projeto proposto, os menores valores são modelados em períodos de quadratura do cenário 2 (cor verde). Para os três projetos, as maiores diluições ocorreram em períodos de sizígia no cenário 1 (cor amarela). Este período também é caracterizado em todos os projetos por apresentar a maior variação de diluição, em conjunto com os períodos de sizígia do cenário 2 (cor azul claro) e 3 (cor rosa). Os períodos de quadratura (cores vermelho, verde e azul escuro) são caracterizados pelas menores diluições, e menores variações destas.

Como forma gráfica de representação do deslocamento lateral das plumas ao final do campo próximo, a Figura 4.6 apresenta a posição central de afloramento da pluma, para os projetos propostos (painéis), ao longo dos ciclos de enchente-vazante em períodos de sizígia e quadratura para os cenários 1, 2 e 3 (cores). Observa-se que dentre os 3 projetos, o antigo apresenta as menores distâncias de afloramento da pluma com relação ao ESS, tendo esta distribuição na direção N-S. O projeto novo apresenta maiores distâncias de afloramento quando comparado ao projeto antigo, 




(a) Projeto Antigo



(b) Projeto Novo

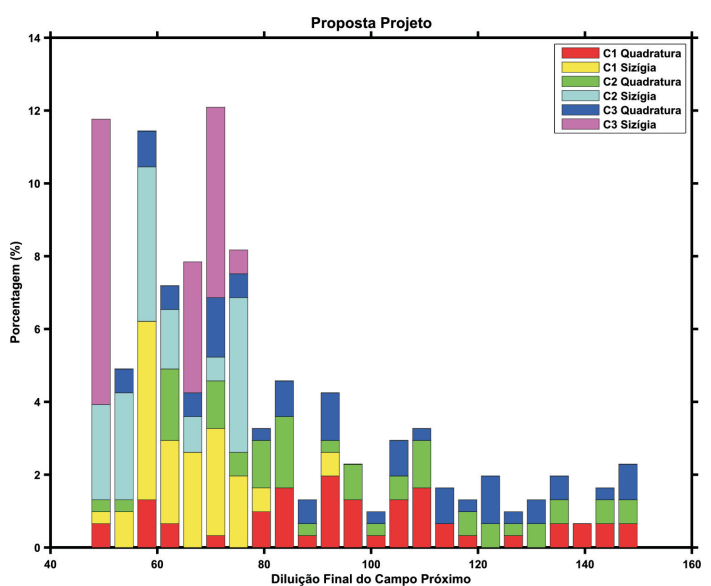

(c) Projeto Proposto

Figura 4.5: Distribuição das diluições modeladas ao final do campo próximo em todas as simulações. Nos painéis (a) Projeto Antigo, (b) Novo e (c) Proposto. C1, C2 e C3 referem-se aos cenário 1, 2 e 3, respectivamente.

mas a mesma direção (N-S). Já o projeto proposto apresenta as maiores distâncias de afloramento, quando comparado aos projetos antigo e novo, ao longo do eixo orientado NW-SE. Todos os projetos, em períodos de sizígia (cores amarelo, azul claro e rosa),apresentaram as maiores distâncias de afloramento. Por outro lado, as menores distâncias são modeladas em períodos de quadratura (cores vermelho, verde e azul escuro). Comparando os três cenários ambientais propostos, em todos os projetos as menores distâncias de afloramento ocorreram em período de quadratura do cenário 1 (cor vermelha) e as maiores distâncias ocorreram no cenário $3 \mathrm{em}$ período de sizígia (cor rosa). 


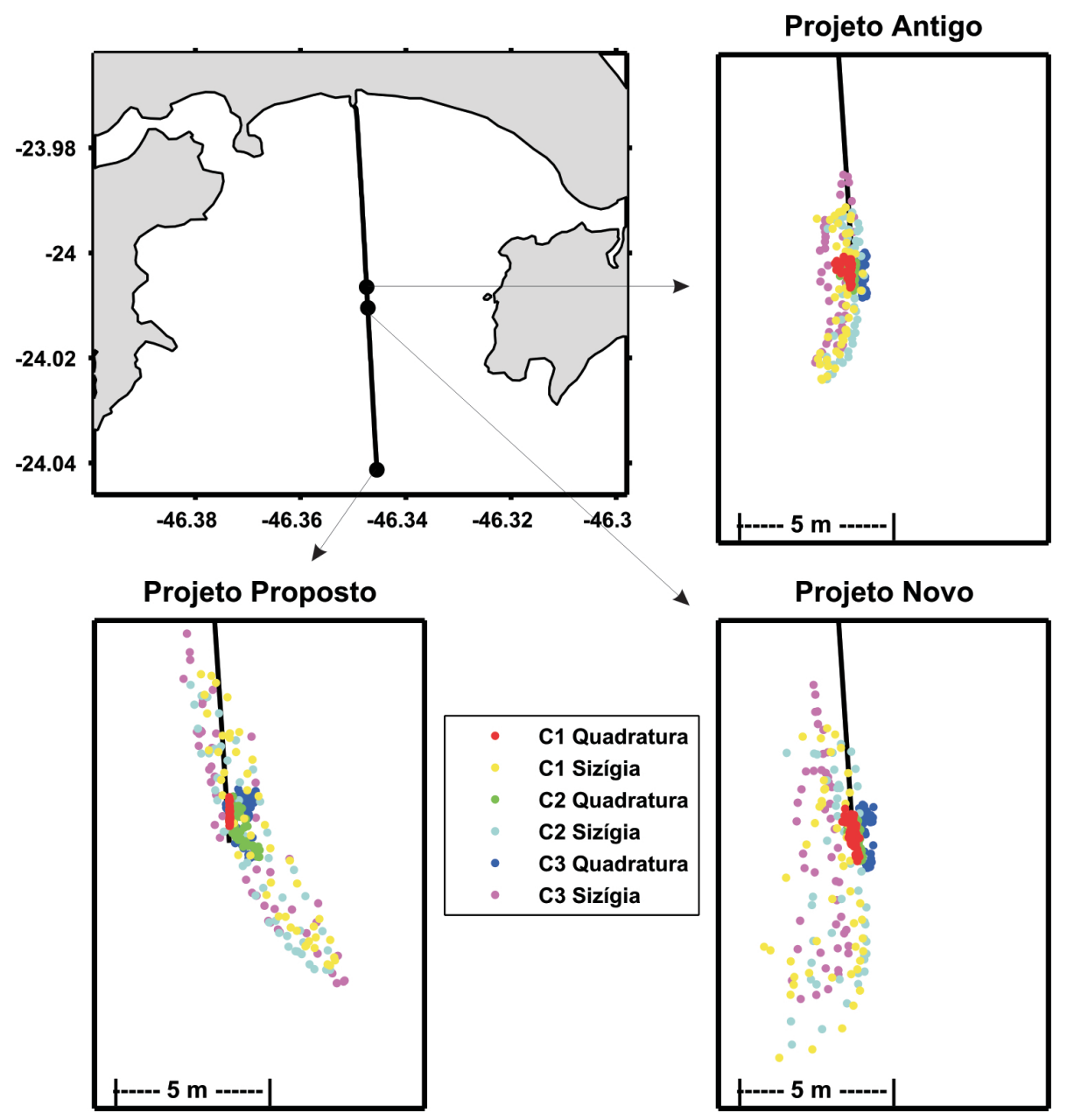

Figura 4.6: Posição central de afloramento da pluma de efluentes do emissário de Santos ao final do campo próximo. Em cada painel, o título indica o projeto correspondente. C1, C2 e C3 referem-se aos cenário 1, 2 e 3, respectivamente. 
Tabela 4.3: Maiores extensões $(\mathrm{km})$ das plumas modeladas no campo distante, em superfície (sup.), $1 \mathrm{~m}$ e $2 \mathrm{~m}$ de profundidade em períodos de sizígia e quadratura, para os cenários 1, 2 e 3. Q-Quadratura, S-Sizígia, i - > 1000 ppm, ii - > 500 ppm, iii - >250 ppm e iv - > 125 ppm.

\begin{tabular}{|c|c|c|c|c|c|c|c|c|c|c|c|c|}
\hline Cenário & \multicolumn{4}{|c|}{ Antigo } & \multicolumn{4}{|c|}{ Novo } & \multicolumn{4}{|c|}{ Proposto } \\
\hline & $\mathrm{i}$ & ii & iii & iv & $\mathrm{i}$ & ii & iii & iv & $\mathrm{i}$ & $\mathrm{ii}$ & iii & iv \\
\hline $1-Q-\sup$ & $\overline{c 1,6}$ & $\overline{3}$ & $4,4^{*}$ & $4,4^{*}$ & 1,6 & 22,7 & $3,3^{*}$ & $3^{*}$ & $1,1,5$ & $3,3,0$ & 44,0 & $4,5^{*}$ \\
\hline $1-Q-1 m$ & - & 1,5 & 2,1 & 3,0 & - & - & 1,2 & 2,2 & - & - & - & - \\
\hline $1-Q-2 m$ & - & - & - & 1,0 & - & - & - & - & - & - & - & - \\
\hline $1-\mathrm{S}-\sup$ & 1,0 & 1,0 & 2,0 & $3,0^{*}$ & 0,5 & 0,5 & 2,0 & $2,0^{*}$ & 0,4 & 1,2 & 2,0 & 3,0 \\
\hline $1-\mathrm{S}-1 \mathrm{~m}$ & - & 0,6 & 1,5 & 0,2 & - & - & 0,2 & 2,0 & - & - & - & - \\
\hline $1-\mathrm{S}-2 \mathrm{~m}$ & - & 0,4 & 1,2 & 1,8 & - & - & - & 0,7 & - & - & - & - \\
\hline $2-Q-\sup$ & $\overline{00,6}$ & 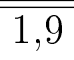 & $2,5^{*}$ & $2,5^{*}$ & $\overline{00,4}$ & $\bar{~} 1,7$ & $2,7^{*}$ & $3,0^{*}$ & 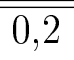 & $0,0,4$ & $\bar{~} 1,3$ & $\overline{c 1,7}$ \\
\hline $2-Q-1 m$ & - & 1,5 & 2,1 & $2,7^{*}$ & - & - & 1,7 & $3,0^{*}$ & - & - & 1,2 & 3,0 \\
\hline $2-Q-2 m$ & - & - & - & 1,0 & - & - & - & - & - & - & - & - \\
\hline $2-\mathrm{S}-\sup$ & 0,5 & 1,0 & 1,0 & $3,0^{*}$ & 0,5 & 0,5 & 1,5 & 2,0 & 0,2 & 0,3 & 0,5 & 0,11 \\
\hline $2-\mathrm{S}-1 \mathrm{~m}$ & - & 0,6 & 1,5 & 2,3 & - & - & 0,2 & 1,0 & - & - & - & 1,0 \\
\hline $2-\mathrm{S}-2 \mathrm{~m}$ & - & 0,2 & 1,0 & 1,5 & - & - & 0,2 & 1,0 & - & - & - & - \\
\hline $3-\mathrm{Q}-\mathrm{sup}$ & 0,1 & 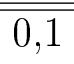 & 0,4 & $\bar{~} 1,1$ & 0,1 &  & $\overline{0,3}$ & 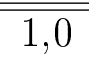 & - & $\overline{00,05}$ & 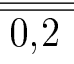 & 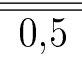 \\
\hline $3-\mathrm{Q}-1 \mathrm{~m}$ & 0,1 & 0,1 & 0,4 & 1,1 & 0,1 & 0,3 & 0,3 & 1,0 & - & 0,05 & 0,2 & 0,5 \\
\hline $3-Q-2 m$ & 0,1 & 0,1 & 0,4 & 1,1 & 0,1 & 0,3 & 0,3 & 1,0 & - & 0,05 & 0,2 & 0,5 \\
\hline $3-\mathrm{S}-\sup$ & 0,5 & 1,0 & 1,5 & 2,2 & 0,1 & 0,2 & 0,3 & 1,5 & - & 0,1 & 0,3 & 0,5 \\
\hline $3-\mathrm{S}-1 \mathrm{~m}$ & 0,5 & 1,0 & 1,5 & 2,2 & 0,1 & 0,2 & 0,3 & 1,5 & - & 0,1 & 0,3 & 0,5 \\
\hline $3-\mathrm{S}-2 \mathrm{~m}$ & 0,5 & 1,0 & 1,5 & 2,2 & 0,1 & 0,2 & 0,3 & 1,5 & - & 0,1 & 0,3 & 0,5 \\
\hline
\end{tabular}

\subsection{Simulações da dispersão no campo distante}

Na Tabela 4.3 estão listadas as maiores extensões das plumas modeladas no campo distante, em superfície, $1 \mathrm{~m}$ e $2 \mathrm{~m}$ em períodos de sizígia e quadratura, para os cenários 1, 2 e 3 . As plumas do projeto proposto apresentaram, em média, as menores distâncias e as menores profundidades, quando comparadas àquelas dos projetos novo e antigo. As plumas do projeto novo apresentam, também, menores distâncias do que as do projeto antigo. A pluma do projeto proposto intercepta a costa somente em concentrações entre 125 ppm e 250 ppm, no cenário 1, em situação de quadratura. Nos demais projetos, intercepta a costas na mesma localidade, em instante de sizígia do cenário 1 e de quadratura do cenário 2. De modo geral, o cenário 1 apresenta as plumas atingindo maiores distâncias, porém mais superficiais, em oposição ao cenário 3, que apresenta as menores distâncias e as plumas mais profundas. 


\section{Capítulo 5}

\section{Conclusões}

Este trabalho conduz às seguintes conclusões:

- Os experimentos com o modelo hidrodinâmico apresentaram resultados condizentes com a literatura. Esse modelo foi validado por meio da comparação entre o nível modelado com aquele da tábua de marés (DHN). As correntes modeladas apresentaram similaridade com correntes medidas, tanto em momentos de vento médio em períodos de quadratura e sizígia de maré, quanto em eventos de entrada de sistema frontal.

- A diluição no campo próximo foi regida pela estratificação do meio e pelo cisalhamento causado pelas correntes na BS. O cenário sem vento apresentou as maiores estratificações da coluna de água e as maiores concentrações ao final do campo próximo. O cenário que simulou a passagem de sistema frontal apresentou a maior mistura das águas, resultando em maiores diluições no campo próximo.

- Para o campo distante, o projeto proposto por esta Dissertação de Mestrado apresentou plumas de pouca profundidade e que interceptaram a costa somente em situação sem vento, em baixamar de quadratura, para concentrações maiores que $125 \mathrm{ppm}$ e menores que $250 \mathrm{ppm}$. Os projetos antigo e novo apresentaram, comparativamente, plumas mais profundas e mais extensas, interceptando a costa em diversos instantes de tempo. Comparando o projeto antigo com o projeto novo, este último sempre apresentou melhores diluições e menores extensões para as plumas no campo distante.

- Trabalhos posteriores podem simular os efluentes lançados pelo ESS com taxa de decaimento e conjuntamente simular concentrações de coliformes fecais. Estes resultados podem ser validados realizando trabalhos de campo com traçadores. Outras épocas do ano podem ser estudadas, variando-se o campo de massa e as forçantes atmosféricas envolvidas. 


\section{Apêndice A}

\section{O Modelo Numério DELFT3D-FLOW}

No módulo hidrodinâmico DELFT3D-FLOW, as componentes da equação do movimento 2.1 e 2.2 correspondem às equações do movimento segundo as direções $x$ e $y$, assumidas como:

$$
\begin{aligned}
& \frac{\partial u}{\partial t}+\frac{u}{\sqrt{G_{x}}} \frac{\partial u}{\partial x}+\frac{v}{\sqrt{G_{y}}} \frac{\partial u}{\partial y}+ \frac{w}{H} \frac{\partial u}{\partial \sigma}-\frac{v^{2}}{\sqrt{G_{x}} \sqrt{G_{y}}} \frac{\partial \sqrt{G_{y}}}{\partial x}+\frac{u v}{\sqrt{G_{x}} \sqrt{G_{y}}} \frac{\partial \sqrt{G_{x}}}{\partial y}-f v= \\
&-\frac{1}{\rho_{0} \sqrt{G_{x}}} P_{x}+F_{x}+\frac{1}{H^{2}} \frac{\partial}{\partial \sigma}\left(v_{m o l}+\frac{\partial u}{\partial \sigma}\right)+M_{x} \quad \text { (A.1) } \\
& \frac{\partial v}{\partial t}+\frac{u}{\sqrt{G_{x}}} \frac{\partial v}{\partial x}+\frac{v}{\sqrt{G_{y}}} \frac{\partial v}{\partial y}+\frac{w}{H} \frac{\partial v}{\partial \sigma}-\frac{u^{2}}{\sqrt{G_{x}} \sqrt{G_{y}}} \frac{\partial \sqrt{G_{y}}}{\partial x}+\frac{u v}{\sqrt{G_{x}} \sqrt{G_{y}}} \frac{\partial \sqrt{G_{x}}}{\partial y}+f u= \\
&-\frac{1}{\rho_{0} \sqrt{G_{y}}} P_{y}+F_{y}+\frac{1}{H^{2}} \frac{\partial}{\partial \sigma}\left(v_{m o l}+\frac{\partial v}{\partial \sigma}\right)+M_{y} \quad \text { (A.2) }
\end{aligned}
$$

Nestas equações, $x, y$ e $z$ são as três coordenadas espaciais e $t$ é o tempo. $u$, $v$ e $w$ são as componentes de corrente segundo os eixos $x, y$ e $z$ e a densidade é simbolizada por $\rho . \sqrt{G_{x}}$ e $\sqrt{G_{y}}$ são coeficientes de transformação de coordenadas curvilineares para retangulares (aproximação que não considera a esfericidade da Terra), $H$ significa a profundidade, $P_{x}$ e $P_{y}$ são os gradientes de pressão hidrostática nas respectivas direções, $F_{x}$ e $\mathrm{F}_{y}$ são os gradientes de tensão radiativa nas respectivas direções, $v_{m o l}$ o coeficiente de viscosidade cinemática molecular, $M_{x}$ e $M_{y}$ são fontes ou sorvedouros de momento nas respectivas direções.

A componente vertical do movimento, na direção $z, 2.3$, é reduzida à equação 
hidrostática:

$$
\frac{\partial P}{\partial \sigma}=-g \rho H
$$

Derivadas desta equação, podem ser obtidas as expressões que resolvem os gradientes horizontais de pressão:

$$
\begin{aligned}
& \frac{1}{\rho \sqrt{G_{x}}} P_{x}=\frac{g}{\sqrt{G_{x}}} \frac{\partial \varphi}{\partial x}+g \frac{H}{\rho \sqrt{G_{x}}} \int_{\sigma}^{0}\left(\frac{\partial \rho}{\partial x}+\frac{\partial \rho}{\partial \sigma} \frac{\partial \sigma}{\partial x}\right) d \sigma \\
& \frac{1}{\rho \sqrt{G_{y}}} P_{y}=\frac{g}{\sqrt{G_{y}}} \frac{\partial \varphi}{\partial y}+g \frac{H}{\rho \sqrt{G_{y}}} \int_{\sigma}^{0}\left(\frac{\partial \rho}{\partial y}+\frac{\partial \rho}{\partial \sigma} \frac{\partial \sigma}{\partial y}\right) d \sigma
\end{aligned}
$$

onde, $\varphi$ é a variação da superfície livre e $\sigma$ é o sistema de coordenada vertical introduzido por Phillips (1957).

Nas equações A.4 A.5 do lado direito da igualdade, o primeiro termo é referente ao gradiente de pressão barotrópico (variações da superfície livre), e o segundo ao gradiente de pressão baroclínico (variações laterais de densidade).

Os gradientes de tensão radiativa, $F_{x}$ e $\mathrm{F}_{y}$, são descritos por:

$$
\begin{aligned}
& F_{x}=\frac{1}{\sqrt{G_{x}}} \frac{\partial \tau_{x x}}{\partial x}+\frac{1}{\sqrt{G_{y}}} \frac{\partial \tau_{x y}}{\partial y} \\
& F_{y}=\frac{1}{\sqrt{G_{x}}} \frac{\partial \tau_{y x}}{\partial x}+\frac{1}{\sqrt{G_{y}}} \frac{\partial \tau_{y y}}{\partial y}
\end{aligned}
$$

Os tensores $\tau_{x x}, \tau_{x y}, \tau_{y x}$ e $\tau_{y y}$ são determinados de acordo com:

$$
\begin{gathered}
\tau_{x x}=\frac{2 v_{H}}{\sqrt{G_{x}}}\left(\frac{\partial u}{\partial x}+\frac{\partial u}{\partial \sigma} \frac{\partial \sigma}{\partial x}\right) \\
\tau_{x y}=\tau_{y x} v\left\{\frac{1}{\sqrt{G_{y}}}\left(\frac{\partial u}{\partial y}+\frac{\partial u}{\partial \sigma} \frac{\partial \sigma}{\partial y}\right)+\frac{1}{\sqrt{G_{x}}}\left(\frac{\partial v}{\partial x}+\frac{\partial v}{\partial \sigma} \frac{\partial \sigma}{\partial x}\right)\right\} \\
\tau_{y y}=\frac{2 v_{H}}{\sqrt{G_{y}}}\left(\frac{\partial v}{\partial y}+\frac{\partial v}{\partial \sigma} \frac{\partial \sigma}{\partial y}\right)
\end{gathered}
$$

Para a equação da continuidade, (equação 2.4), a representação utilizada no DELFT3D-FLOW é:

$$
\frac{\partial \varphi}{\partial t}+\frac{1}{\sqrt{G_{x}} \sqrt{G_{y}}} \frac{\partial(H) U \sqrt{\left(G_{y}\right)}}{\partial x}+\frac{1}{\sqrt{G_{x}} \sqrt{G_{y}}} \frac{\partial(H) V \sqrt{\left(G_{x}\right)}}{\partial y}=Q
$$

Na equação A.11, $U$ e $V$ significam os transportes por unidade de distância horizontal nas respectivas direções $x$ e $y$; $Q$ representa as contribuições por unidade de área de descarga ou sumidouro de água. $Q$ é dado por, com $q_{f}$ sendo as fontes e 
$q_{s}$ os sorvedouros:

$$
Q=H \int_{-1}^{0}\left(q_{f}-q_{s}\right) d \sigma
$$

As equações de difusão de sal e calor (equações 2.5 e 2.6), tendo $\lambda$ como processos de decaimento de primeira ordem, $S$ a salinidade e $T$ a temperatura, são representadas por:

$$
\begin{gathered}
\frac{\partial H S}{\partial t}+\frac{1}{\sqrt{G_{x}} \sqrt{G_{y}}}\left\{\frac{\partial \sqrt{G_{y}} H u S}{\partial x}+\frac{\partial \sqrt{G_{x}} H v S}{\partial y}\right\}+\frac{\partial w S}{\partial \sigma}= \\
\frac{H}{\sqrt{G_{x}} \sqrt{G_{y}}}\left\{\frac{\partial}{\partial x}\left(\frac{D_{H}}{\sigma} \frac{\sqrt{G_{y}}}{\sqrt{G_{x}}} \frac{\partial S}{\partial x}\right)+\left(\frac{D_{H}}{\sigma} \frac{\sqrt{G_{x}}}{\sqrt{G_{y}}} \frac{\partial S}{\partial y}\right)\right\}+ \\
\frac{1}{H} \frac{\partial}{\partial \sigma}\left(\frac{v_{m o l}}{\sigma_{m o l}}+\frac{\partial S}{\partial \sigma}\right)-\lambda H+F s \\
\frac{\partial H T}{\partial t}+\frac{1}{\sqrt{G_{x}} \sqrt{G_{y}}}\left\{\frac{\partial \sqrt{G_{y}} H u T}{\partial x}+\frac{\partial \sqrt{G_{x}} H v T}{\partial y}\right\}+\frac{\partial w T}{\partial \sigma}= \\
\frac{H}{\sqrt{G_{x}} \sqrt{G_{y}}}\left\{\frac{\partial}{\partial x}\left(\frac{D_{H}}{\sigma} \frac{\sqrt{G_{y}}}{\sqrt{G_{x}}} \frac{\partial T}{\partial x}\right)+\left(\frac{D_{H}}{\sigma} \frac{\sqrt{G_{x}}}{\sqrt{G_{y}}} \frac{\partial T}{\partial y}\right)\right\}+ \\
\frac{1}{H} \frac{\partial}{\partial \sigma}\left(\frac{v_{m o l}}{\sigma_{m o l}}+\frac{\partial T}{\partial \sigma}\right)-\lambda H+F t
\end{gathered}
$$

No modelo DELFT3D-FLOW estão discretizadas as equações de conservação de massa e de momentum. O sistema de equações é fechado por uma versão da equação de estado que é função da temperatura, da salinidade e da pressão $(P)$. A versão utilizada é derivada de Eckart (1958):

$$
\rho=\frac{1.000 P_{0}}{\lambda+\alpha_{0} P_{0}}
$$

onde

$$
\begin{gathered}
\lambda=1779,5+11,25 T-0,0745 T^{2}-(3,80+0,01 T) S, \\
\alpha_{0}=0,6980, \\
P_{0}=5890+38 T-0,375 T^{2}+3 S .
\end{gathered}
$$

O DELFT3D-FLOW apresenta vários esquemas de fechamento turbulento e é totalmente não linear, inclusive nas parametrizações dos atritos de fundo e superfície. Tendo $g$ como a aceleração da gravidade, $\rho_{0}$ a densidade de referência da água do mar, $\vec{u}_{b}$ a magnitude da velocidade horizontal na primeira camada acima do fundo 
e $C_{3 D}$ o coefficiente de Chézy, temos o atrito de fundo $\left(\vec{\tau}_{b}\right)$ descrito por:

$$
\vec{\tau}_{b}=\frac{g \rho_{0} \vec{u}_{b}\left|\vec{u}_{b}\right|}{C_{3 D}^{2}}
$$

Com $\rho_{a}$ sendo a densidade do ar, $U_{10}$ a magnitude da velocidade do vento 10 metros acima da superfície livre (dependente do tempo e do espaço) e $C_{d}$ o coeficiente de arrasto dependente de $U_{10}$, temos o atrito de superfície $\left(\vec{\tau}_{s}\right)$ descrito por:

$$
\left|\vec{\tau}_{s}\right|=\rho_{a} C_{d} U_{10}^{2}
$$

O coeficiente de arrasto $C_{d}$ é dependente da velocidade do vento e é dado por, de acordo com Smith \& Banke (1975):

$$
C_{d}\left(U_{10}\right)=\left\{\begin{array}{l}
0,00063 \text { se } U_{10}=0(\mathrm{~m} / \mathrm{s}) \\
\frac{0,00803 U_{10}}{100} \text { se } 100(\mathrm{~m} / \mathrm{s})<U_{10}>0(\mathrm{~m} / \mathrm{s}) \\
0,00723 \text { se } U_{10} \geq 100(\mathrm{~m} / \mathrm{s})
\end{array}\right.
$$

O método numérico do DELFT3D-FLOW é baseado em diferenças finitas. Para discretizar as equações demonstradas acima no espaço, a área é representada por uma grade curvilinea. A configuração das variáveis na grade é do tipo Arakawa-C, com os pontos de pressão (nível) localizados no centro das células e as componentes de velocidade são situados nas faces, de forma perpendicular.

Detalhes sobre a implementação em diferenças finitas das equações descritas podem ser obtidas em Delft3DFLOW (2006). 


\section{Apêndice B}

\section{O Modelo Numério UM3}

Neste Anexo B, serão apresentadas as considerações teóricas sobre o modelo numérico de campo próximo UM3. A descrição dos processos relativos aos cálculos considerados pelo UM3 foram obtidas de Baumgartner et al. (1994).

Entranhamento é o processo pelo qual o jato incorpora material do ambiente. Pode ser pensado como um processo em que massa flui para o interior do jato através de sua superfície, vindo do exterior.

A forma do elemento é muito importante para modelar o jato, pois é determinante para a área projetada que é diretamente proporcional à força exercida pelo entranhamento. A forma do elemento é estabelecida arbitrariamente. Normalmente, uma interpretação particular sobre o jato é utilizada para estabelecer a distribuição de massa sobre a trajetória, que sustenta que o jato tem forma cilíndrica. Entretanto, o jato é definido por uma superfície lisa, aumenta de tamanho conforme afasta-se da fonte e tem a trajetória curva, tendo portanto a forma de uma secção de cone fletida. Em geral, o jato em forma de cone fletido tem uma área projetada que difere substancialmente da área projetada de um cilindro. Assim, o crescimento e os termos de curvatura são necessários para descrever com precisão a área projetada do jato (Frick 1984).

É assumido que a pluma está em estado estacionário. A pluma permanece invariante enquanto elementos que se deslocam por ela mudam sua forma e posição com o tempo. No entanto, condições podem ser alteradas, em intervalos de tempo maiores quando comparados ao tempo decorrente da diluição inicial. O estado estacionário pressuposto é utilizado para determinar o comprimento do jato, em função da velocidade média instantânea, o seu comprimento inicial, e a velocidade inicial do efluente. Deste modo, o comprimento do elemento não é geralmente mantido constante, sendo alterado de acordo com as variações de velocidade do meio. Com isto, o raio do elemento deve responder a esta convergência ou divergência de velocidade, bem como o entranhamento.

O limite exterior da pluma coincide inicialmente com a borda do orifício que lança 
o efluente. Para integração a partir da condição inicial, e utilizando condições de borda, o volume do jato é calculado baseando-se na massa entranhada e assumindo a forma do elemento. Pressupõe-se que as propriedades da pluma na fronteira são indistinguíveis das do ambiente adjacente. Isto implica que a massa que atravessa a área projetada do jato possui a mesma velocidade do ambiente.

O modelo inclui princípios de conservação de massa (continuidade), momento horizontal e energia. O momento vertical não é conservado porque é normalmente alterado pela flutuabilidade do jato.

A conservação do momento é dada por:

$$
\frac{d m \vec{V}}{d t}=\vec{U} \frac{d m}{d t}-m \frac{\rho_{a}-\rho}{\rho} \vec{g}
$$

onde $m$ é a massa de cada elemento da pluma $\left(m=\rho \pi b^{2} h\right), \rho_{a}$ e $\rho$ são as densidades do ambiente e do elemento, respectivamente e $\vec{g}$ é o vetor aceleração gravidade. Idealmente, $\vec{U}$ representa a velocidade média da corrente e $\vec{V}$ é a velocidade dos elementos que compõem o jato.

A Equação B.1 indica que a mudança no momento da pluma é devido a introdução de momento pelo entranhamento de massa $d m$ e a mudança no momento vertical é gerado pela força de empuxo. Para avaliar o termo de empuxo na equação de conservação do momento, é necessário definir a equação de conservação de energia, que é:

$$
\frac{d m c_{p}\left(T-T_{r e f}\right)}{d t}=c_{p}\left(T_{a}-T_{r e f}\right) \frac{d m}{d t}
$$

onde $c_{p}$ é o calor específico a pressão constante. $T, T_{a}$ e $T_{r e f}$ são as temperaturas médias do elemento, a temperatura do ambiente, e uma temperatura de referencia arbitrária, respectivamente.

A conservação de salinidade é expressa por:

$$
\frac{d m S}{d t}=S_{a} \frac{d m}{d t}
$$

onde $S$ e $S_{a}$ são as salinidades do elemento e do ambiente, respectivamente.

A densidade é derivada da equação de estado definida por Teeter \& Baumgartner (1979). Esta equação é independente da pressão, limitando UM3 a águas rasas.

Três mecanismos de entranhamento são considerados: de Taylor (aspirado), forçado, e área projetada (turbulento). Entranhamento de Taylor é provocado por cisalhamento pois, regiões com alta velocidade são regiões de baixa pressão relativa provocando fluxo de massa para dentro do jato. O entranhamento forçado é devido à presença de corrente que advecta massa para dentro da pluma.

Entranhamento de área projetada é composto de três termos. O primeiro termo 
é proporcional ao comprimento e ao raio do jato, o segundo ao crescimento em diâmetro da pluma e o terceiro à curvatura da trajetória do jato.

A hipótese do entranhamento da área projetada é descrita por

$$
\frac{d m}{d t}=\rho_{a} A_{p} u
$$

onde $d m$ é o incremento de massa por entranhamento em cada incremento de tempo $d t, A_{p}$ é a área projetada, $u$ é velocidade da corrente normal à área projetada e $\rho_{a}$ é a densidade do ambiente.

A equação B.4 é uma expressão parcial para o entranhamento; este estado é parcialmente forçado pelo montante de massa adicionado ao jato no tempo $\Delta t$ e é igual ao fluxo de massa total sobre sua superfície. A equação completa do entranhamento é a soma desta forçante com os termos do entranhamento de Taylor:

$$
\frac{d m}{d t}=-\rho \overrightarrow{A_{p}} \vec{U}+\rho A_{t} v_{t}
$$

onde $A_{t}$ é a área do jato em contato com o fluido ambiente e $v_{t}$ é a velocidade de aspiração de Taylor.

A área do jato em contato com o ambiente, $A_{t}$ é descrita por:

$$
A_{t}=2 \pi b h
$$

onde $h$ e $b$ são o comprimento e o raio do jato, respectivamente.

A velocidade de aspiração de Taylor, $v_{t}$, é frequêntemente relacionada à velocidade média da pluma através do coeficiente de proporcionalidade $\alpha$ :

$$
v_{t}=\alpha \mid \vec{V}
$$

onde $\alpha$ varia de 0,082 para jatos descritos por perfis gaussianos à 0,057 para jatos em ambientes estáticos. Frick (1984) apresenta o valor médio de 0,1 como sendo mais indicado.

Quando as plumas adjacentes crescem significativamente elas se fundem e se entranham umas às outras. Fusão de plumas tem o efeito imediato de reduzir entranhamentos, reduzindo a área de contato entre a pluma e seus arredores. Apenas a fusão das plumas adjacentes lançadas por difusores lineares são considerados no UM3.

A aproximação básica para a fusão de jatos é 1) redução das áreas de entranhamento, tanto de Taylor quanto forçado, e a perda de superfície exposta que ocorre quando jatos vizinhas interferem uns com os outros, e, 2) confinar a massa do jato no espaço entre o que é conhecido e disponível pelas considerações simétricas. Assume-se que os jatos são idênticos e qualquer interação entre elas é recíproca. 
Para completa descrição do problema, as bordas e as condições iniciais devem ser especificadas. A condição de borda é o local e a subsequente posição onde a pluma vai ser determinado pela integração das equações. Uma outra condição de borda é o raio inicial da pluma. Condições iniciais incluem o fluxo de velocidade, a temperatura do efluente, etc.

Em geral o procedimento computacional descrito pelo modelo é: 1) o incremento de tempo é estabelecido, 2) as equações de entranhamento são usadas para determinar a quantidade de massa que vai ser adicionada neste incremento de tempo, 3) este aumento é então comparada com o aumento de massa e as devidas adaptações são feitas para o incremento de tempo e as componentes de entranhamento satisfazer os criterios apropriados, 4) as equações de movimento e outras equações do modelos são resolvidas e 5) um novo incremento de tempo é estabelecido e o ciclo se repete. 


\section{Referências Bibliográficas}

Andutta, F., Miranda, L. B., C. Ancona, F. S. C. \& Giansella, S. (2006), Montly variations of physical and chemical properties observed in santos bay and santos estuarine channel, in C. C. of Researches in Education \& Sciences, eds, 'EHWC Environmental and Health World Congress', COPEC - Council of Researches in Education and Sciences, Santos, SP, Brasil, p. no prelo.

Baumgartner, D. J., Frick, W. E. \& Roberts, P. J. W. (1994), Diluition models for effluent discharges, Vol. 1 of 1, 3 edn, EPA.

Bleninger, T. \& Jirka, G. H., eds (2004), Near and farfield model coupling methodology for wastewater discharges, International Association of Hydraulic Engineering and Research, 4th International Symposium on Environmental Hydraulics and 14th Congress of Asia and Pacific Division, Hong Kong, China.

Bosquilha, G. (2002), Estudo da distribuição de surfactantes aniônicos e de polifosfatos no sistema estuarino de santos/são vicente e baía de santos (são paulo, brasil) e avaliação das metodologias aplicadas, Master's thesis, Instituto Oceanográfico da Universidade de São Paulo, São Paulo, Brasil.

Carvalho, J., Roberts, P. J. W. \& Roldão, J. (2002), 'Field observations of ipanema beach outfall', Journal of Hidraulic Engineering 2(1), 151-160.

Castro, B. M. (1996), 'Correntes e massas de água da plataforma continental norte de são paulo', Tese de livre docência. Instituto Oceanográfico da Universidade de São Paulo.

CETESB (2002), Relatório de qualidade das águas litorâneas do estado de são paulo - balneabilidade das praias, Technical report, Companhia de Tecnologia e Saneamento Ambiental - Secretaria de Estado do Meio Ambiente.

CETESB (2004), Relatório de qualidade das águas litorâneas do estado de são paulo - balneabilidade das praias, Technical report, Companhia de Tecnologia e Saneamento Ambiental - Secretaria de Estado do Meio Ambiente. 
CETESB (2005), Relatório de qualidade das águas litorâneas do estado de são paulo - balneabilidade das praias, Technical report, Companhia de Tecnologia e Saneamento Ambiental - Secretaria de Estado do Meio Ambiente.

CETESB (2007), Emissários submarinos, projeto, avaliação de impacto ambiental e monitoramento, Vol. 1 of 1, Editores Cláudia Condé Lamparelli, Jayme Pinto Ortiz.

Clark, J. R. (1995), Coastal zone management handbook, Vol. 1, CRC.

Coelho, A. L. (2007), Resposta da Plataforma Continental Sudeste a ventos sazonais e sinóticos de verão: estudos numéricos, $\mathrm{PhD}$ thesis, Instituto Oceanográfico da Universidade de São Paulo, São Paulo, Brasil.

CPTEC/INPE (1996), Boletim Climanálise, Vol. 21 of 1, CPTEC/INPE.

David, C. (2003), Distribuição da biomassa microfitobentônica na Baía de Santos (SP, Brasil) com ênfase para a região do emissário submarino. Aspectos da produção primária e florística., $\mathrm{PhD}$ thesis, Instituto Oceanográfico da Universidade de São Paulo, São Paulo, Brasil.

Delft3DFLOW (2006), Delft3dFLOW: Simulation of multidimensional hydrodinamic flows and transport phenomena, including sediments, WL | Delft Hydraulics, Holanda.

Delft3DWAQ (2006), Delft3dWAQ: Detailed description of processes, WL | Delft Hydraulics, Holanda.

DHN (2007), 'Diretoria de hidrografia e navegação. tábua de marés fevereiro de 2007.'. Online;[accesso em 07-Janeiro-2009].

URL: http://www.mar.mil.br/dhn/chm/tabuas/50225Fev200\%.htm

Eckart, C. (1958), 'Properties of water: Ii. the equation of state of water and sea water at low temperatures and pressures', American Journal Science 256, 225240 .

Egbert, G., Bennett, A. \& Foreman, M. (1994), 'Topex/poseidon tides estimated using a global inverse model', Journal of Geophysical Research 99(24), 821-824.

FEMAR (2000), Catálogo de estações maregráficas brasileiras, Fundação de Estudos do Mar.

Fúlvaro, V. \& Ponçano, W. (1976), Sedimentação atual do estuário e baía de santos: um modelo geológico aplicado e projetos de expansão da zona portuária, in S. B. 
de Geologia, ed., 'Congresso Brasileiro de Geologia e Engenharia', Belo Horizonte, Brasil.

Frick, W. E. (1984), 'Nonempirical closure of the plume equations', Atmospheric Environmental 18(4), 653-662.

Harari, J. \& Camargo, R. (1998), 'Modelagem numérica da região costeira de santos (sp): circulação de maré', Revista Brasileira de Oceanografia 46(2), 135-156.

Harari, J., Camargo, R. \& Cacciari, P. (2000), 'Resultado da modelagem numérica hidrodinâmica em simulações tridimensionais das correntes de maré na baixada santista', Revista Brasileira de Recursos Hídricos 5(1), 71-78.

Hillerbrand, G. (2003), Coupling of near- and far-field models for prediction of treated sewage efluent discharges into the coastal ocean, Master's thesis, universitat Karlsruhe.

Jirka, G. H., Abraham, G. \& harleman, D. R. F. (1976), An assessment of techniques for hydrothermal prediction, Department of Civil Engineering, MIT for U.S. Neclear Regulatory Comission.

Kanamitsua, M., Kumarb, A., Juangc, H.-M. H., Schemmd, J.-K., Wange, W., Yangf, F., Hongg, S.-Y., Pengh, P., Cheni, W., Moorthij, S. \& Jik, M. (2002), 'Ncep dynamical seasonal forecast system 2000', Bulletin of the American Meteorological Society 83(7), 1019-1037.

Knill, M. W. (1984), 'Outfalls versus inland treatment', The Public Health Engineer 12(2), 89-93.

Marques, G. M. (2006), 'Avaliação do campo de toxicidade gerado pelo emissário de santos/são vicente através de modelo ecotoxicológico acoplado a modelos hidrodinâmico e de dispersão', Trabalho de Graduação - Instituto Oceanográfico da Universidade de São Paulo.

Milênio (2009), 'Projeto instituto do milênio'. Online;[accesso em 07-Janeiro-2009].

URL: http://www.institutomilenioestuarios.com.br/zonacosteira.html

Miranda, E. E. \& Coutinho, A. C. (2004), 'Brasil visto do espaço'. Online;.

URL: http://cdbrasil.cnpm.embrapa.br

Miranda, L. B., Andutta, F. \& Leite, Z. R. B. (2007), Relatório preliminar projeto ecosan, Technical report, Instituto Oceanográfico da Universidade de São Paulo.

NASA (2009), 'Visible earth'. Online;[accesso em 07-Janeiro-2009].

URL: http://visibleearth.nasa.gov/ 
Nations, U., ed. (1992), Agenda 21: Rio Declaration, United Nations, united nations Conference on Environment and Development, Rio de Janeiro, Brasil.

Occhipinti, A. G. (1970), Estudos preliminares necessários a disposição oceânica de esgotos, PhD thesis, Escola de Engenharia de São Carlos da Universidade de São Paulo.

Phillips, N. A. (1957), 'A coordinate system having some special advantages for numerical forecasting', Journal of Meteorology 14(1), 184-185.

Rezende, J. H. M. (2003), Intrusões da água central do atlântico sul na plataforma continental sudeste durante o verão, PhD thesis, Instituto Oceanográfico da Universidade de São Paulo, São Paulo, Brasil.

Roberts, P. J. W. \& Tian, X. (2004), 'New experimental techniques for validation of marine discharge models', Environmental Modelling and Software 19(1), 691-699.

Rodrigues, M. L. G., Franco, D. \& Sugahara, S. (2004), 'Climatologia de frentes frias no litoral de santa catarina', Revista Brasileira de Geofísica 22(2), 135-151.

Smith, S. D. \& Banke, E. G. (1975), 'Variation of the sea-surface drag coefficient with wind speed', Journal Royal Meteorology Society 101(1), 665-673.

Teeter, A. M. \& Baumgartner, D. J. (1979), Prediction of initial mixing for municipal ocean discharges, 43 edn, USEPA Environmental Research Laboratory, Corvallis, OR, USA.

Walters, J. C. \& Heston, C. (1982), 'Removing the tidal-period variations from time-series data using low-pass digital filters', Journal of Physical Oceanography $\mathbf{1 2 ( 1 ) , ~ 1 1 2 - 1 1 5 . ~}$

Warner, J. C., Geyer, W. R. \& Lerczak, J. A. (2005), 'Numerical modeling of an estuary: a comprehensive skill assessment', Journal of geophysical Research $\mathbf{1 1 0}(1), 13$.

Wilmott, C. J. (1981), 'On the validation models', Physical Geography 2(1), 184-194.

Zhang, X. Y. (1995), Ocean outfall modeling - interfacing near and farfield models with particle tracking method, $\mathrm{PhD}$ thesis, Massachusetts Institute of Technology.

Zhang, X. Y. \& Adams, E. E. (1999), 'Prediction of near field plume caracteristics using far field circulation model', Journal of Hydraulics Engineering 125(3), 233241. 